DOE/OR/01-2399\&D0

\title{
Fiscal Year 2009 Phased Construction Completion Report for EU Z2-36 in Zone 2, East Tennessee Technology Park, Oak Ridge, Tennessee
}

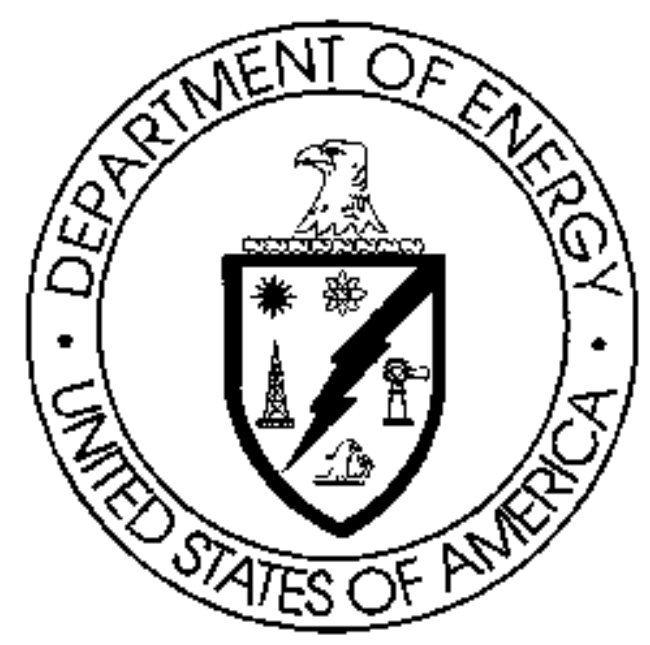

This document is approved for public reloess per roview by: 


\section{Fiscal Year 2009 Phased Construction Completion Report for EU Z2-36, East Tennessee Technology Park, Oak Ridge, Tennessee}

Date Issued-February 2009

Prepared for the

U.S. Department of Energy

Office of Etrvironmental Management

BECHTEL JACOBS COMPANY LLC managing the Accelerated Cleanup Activities at the East Tennessee Technology Park under contract DE-AC05-98OR22700 for the U.S. DEPARTMENT OF ENERGY 
Reference to any specific commercial product, process or service by trade name, trademark, manufacturer, or otherwise does not necessarily constitute or imply its endorsement, recommendation, or favoring by the United

States Government or any agency thereof or its contractors or subcontractors. 


\section{CONTENTS}

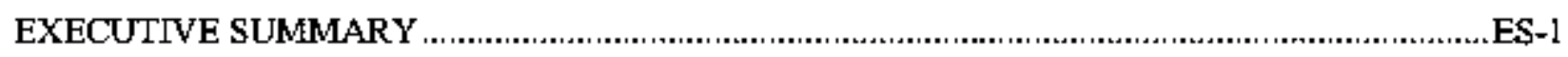

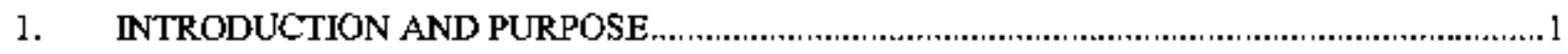

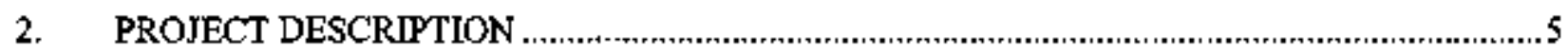

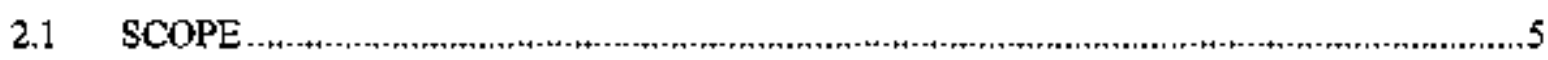

2.I.1 Exposure Unit Groups ..................................................................................

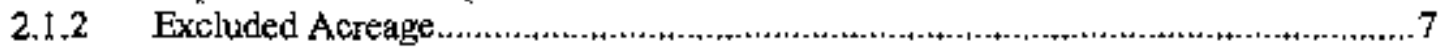

2.1.3 Data Quality Dbjectives and Soil Unit Classiffications ..........................................7

2.1.4 Federal Facility Agreement Sites ..................................................................... 7

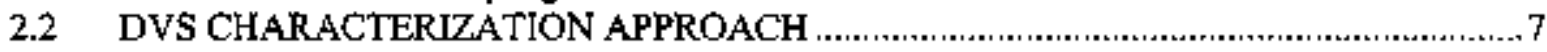

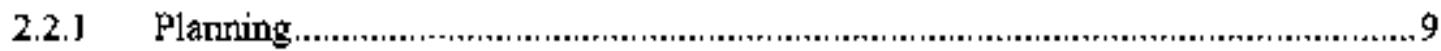

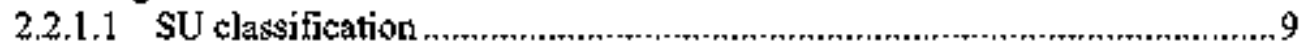

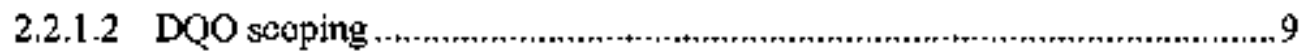

2.2.2 Class 2 SU Characterization Approach ...........................................................9

2.2.3 Class 3 SU Characterization Approach .......................................................... 12

2.2.4 Program Execution ..................................................................................... 14

2.2.5 Action/No Further Action Decision/Communication......................................... 16

2.2.6 Docurnentation and Records...................................................................... 17

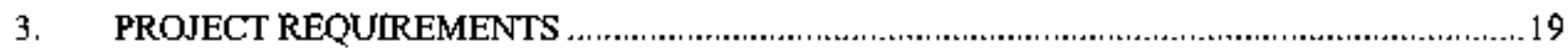

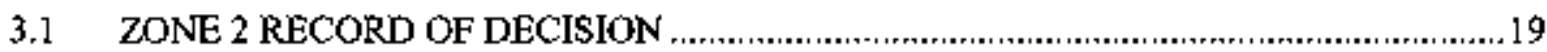

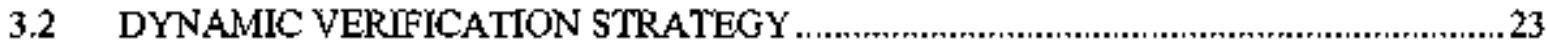

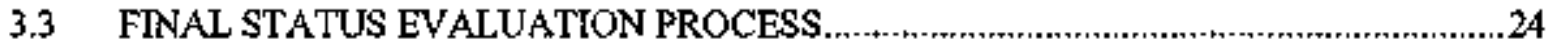

3.3.1 Action/No Further Action Decision ............................................................24

3.3.2 Special Data Uses and Considerations ..........................................................2. 27

3.3.3 Qualitative Risk Screening for Unrestricted Use .................................................28

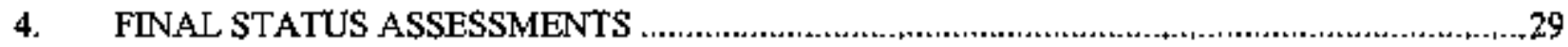

4.1 EXPOSURE UNIT EVALUATION

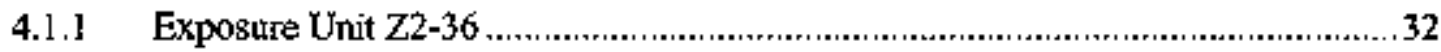

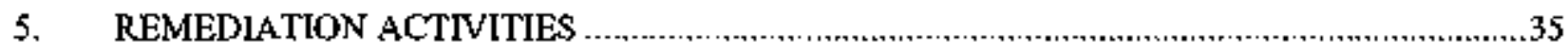

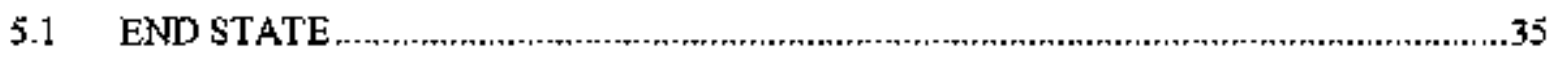

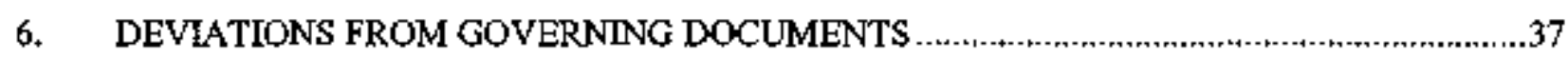

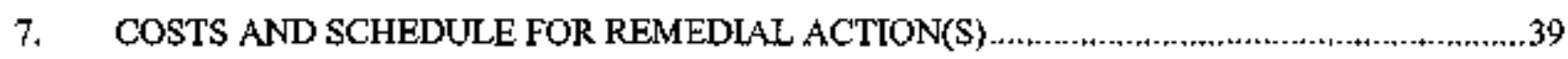

8. WASTE MANAGEMENT ACTTVITIES FOR REMEDIAL ACTION(S) ................................41

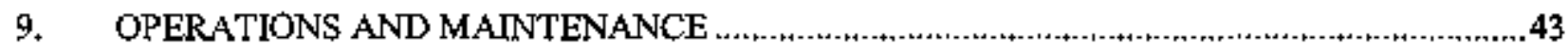

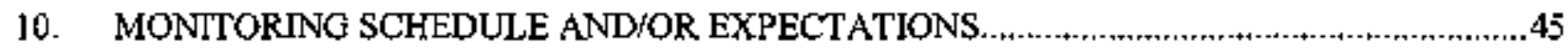




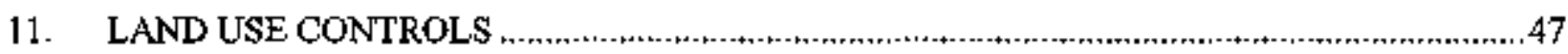

11.1 POSSIBLE LIFTING OF LAND USE CONTROLS ................................................ 47

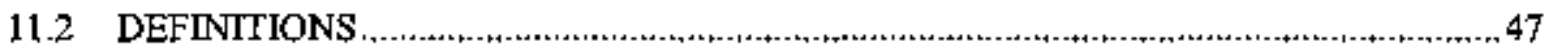

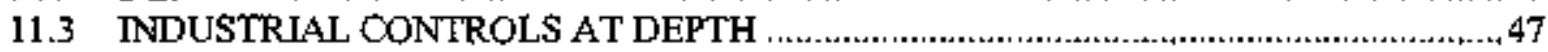

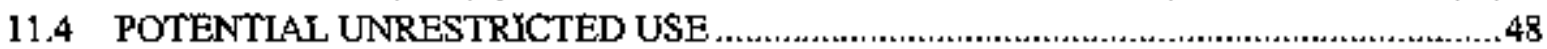

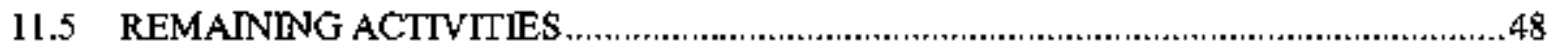

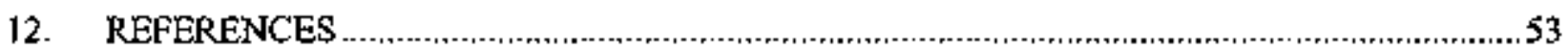

APPENDDX A. EXPOSURE UNIT 22-33 SOUTH PARK AREA.

TECHNICAL, MEMORANDUM ........................................................................ 


\section{FIGURES}

I. ETTP site map with Zone 2 DQO scoping EU groups and EUs. ........................................2

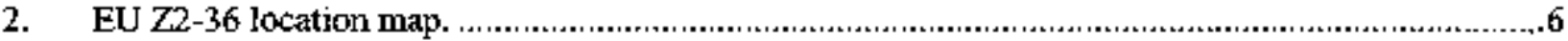

3. Zone 2 DVS Class 1 and Class 2 SU sampling and analysis decision process flow.......................11

4. Zone 2 DVS Class 3 and Class 4 SU sampling and analysis decision process flow......................13

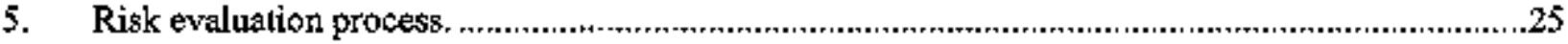

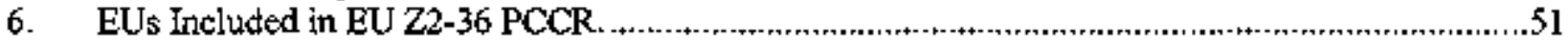

\section{TABLES}

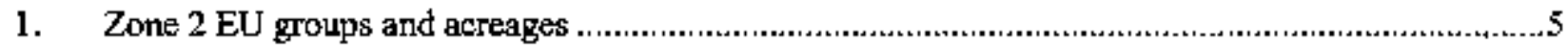

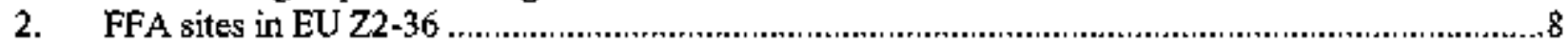

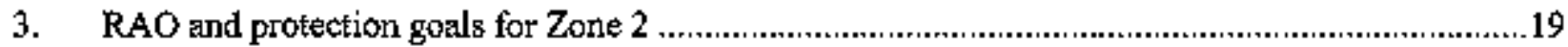

4. Chemicals and radionuclides required for analysis in Zone 2 DVS samples and

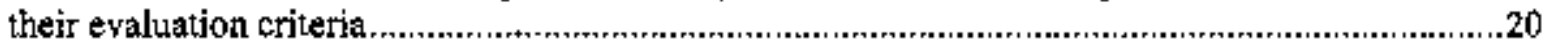

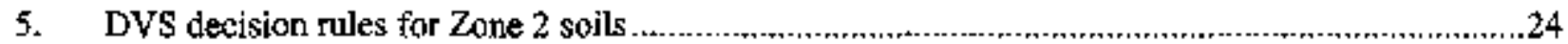

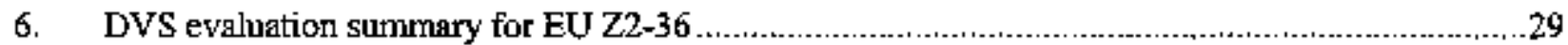

7. Final status assessment summary for EU Z2-36 ............................................................

8. Summary of conclusions for EU Z2-36 Zone 2 ROD Appendix A FFA sites ..............................32

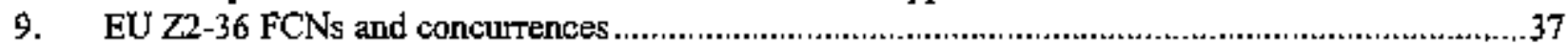




\section{ACRONYMS}

\begin{tabular}{|c|c|}
\hline AP & assessment point \\
\hline ARL & average remediation level \\
\hline BAR & biased area remediation \\
\hline BOS & Balance of Site \\
\hline $\mathrm{CD}$ & compact disc \\
\hline $\mathrm{OOC}$ & contaminant of concern \\
\hline $\mathrm{D} \& \mathrm{D}$ & deactivation and demolition \\
\hline DOE & U.S. Department of Energy \\
\hline DQO & data quality objective \\
\hline DVS & Dynamic Verification Stategy \\
\hline DWP & Dynamic Work Plan \\
\hline ELCR & excess lifetime cancer risk \\
\hline EPA & U.S. Environmental Protection Agency \\
\hline ETTP & East Tennessee Technology Park \\
\hline EU & exposure unit \\
\hline FCN & Field Change Notice \\
\hline FFA & Federal Facility Agreement \\
\hline FY & fiscal year \\
\hline FIDLER & field instrument for the detection of low energy radiation \\
\hline HI & hazard index \\
\hline MARSSIM & Multi-Agency Radiation Survey and Site Investigation Manual \\
\hline MCL & maximum contaminant level \\
\hline MP & mid-point \\
\hline NFA & no further action \\
\hline OREIS & Oak Ridge Environmental Information System \\
\hline $\mathrm{PCB}$ & polychlorinated biphenyI \\
\hline PCCR & Phased Construction Completion Report \\
\hline PRG & preliminary remediation goal \\
\hline QAPP & Quality Assurance Program Plan \\
\hline $\mathrm{QC}$ & quality control \\
\hline $\mathrm{RA}$ & remedial action \\
\hline $\mathrm{RAO}$ & remedial action objective \\
\hline RAR & Remedial Action Report \\
\hline RDR/RAWP & RemediaI Design ReportRemedial Action Work Plan \\
\hline $\mathrm{RCW}$ & recirculating cooling water \\
\hline RL & remediation level \\
\hline ROD & Record of Decision \\
\hline SL & screening level \\
\hline SOP & standard operating proceduse \\
\hline SU & soil unit \\
\hline SVOC & semivolatile organic compound \\
\hline TAL & target analyte list \\
\hline TDEC & Tennessee Department of Environment and Conservation \\
\hline $\mathrm{TM}$ & techmical memorandum \\
\hline UST & underground storage tank \\
\hline VOC & volatile organic compound \\
\hline
\end{tabular}




\section{EXECUTIVE SUMMARY}

The Record of Decision for Soil, Buried Waste, and Subsufface Structure Actions in Zone 2, East Tennessee Technology Park Oak Ridge, Tennessee (DOE/OR/01-2161\&D2) (Zone 2 ROD) acknowledged that most of the 800 acres in Zone 2 were contaminated, but that sufficient data to confim the levels of contamination were lacking. The Zone 2 ROD further specified that a sampling strategy for filling the data gaps would be developed. The Remedial Design Report/Remedial Action Work Plan for Zone 2 Soils, Slabs, and Stubstaface Stnuctures, East Tennessee Technology Park, Oak Ridge. Tennessee (DOE/OR/01-2224\&D3) (Zone 2 RDR/RAWP) defined the sampling strategy as the Dymanic Verification Strategy (DVS), generally following the approach used for characterization of the Zone 1 exposure units (EUs).

The Zone 2 ROD divided the Zone 2 area into seven geographic areas and 44 EUs. To facilitate the data quality objectives (DQOs) of the DVS process, the Zone 2 RDR/RAWP regrouped the 44 EUs into $12 \mathrm{DQO}$ scoping EU groups. These groups facilitated the DQO process by placing similar facilities and their support facilities together and allowing identification of data gaps. The EU groups were no longer pertinent after DQO planning was completed and characterization was conducted as areas becane accessible. As the opportunity to complete characterization became available, the planned DVS program was completed for the EU addressed in this document (EU Z2-36). The purpose of this PCCR is to address the following:

- Document DVS characterization results for EU 22-36,

- Describe and document the risk evaluation and determine if the EU meets the Zone 2 ROD requirements for unrestricted industrial use to $10 \mathrm{ft}$ bgs, and

- Identify additional areas not defined in the Zone 2 ROD that require remediation based on the DVS evaluation results.

Approximately 15 acres are included in the EU addressed in this PCCR. Based on the results of the DVS evaluation, approximately 15 acres are recommended for unrestricted industrial use to $10 \mathrm{ft}$ bgs. Two Federal Facility Agreement sites as listed below are included in Appendix A of the Zone 2 ROD as being in EU Z2-36. The K-1423 Grease Burial FFA Site is included in the Main Plant DQO Scoping Package as being in EU Z2-36, but it is actually located east of K-1423 in EU Z2-25 and will be addressed in the technical memorandum for that EU. The DOE recommends NFA for the two FFA sites here.

- K-1098-C Asphalt Plant,

- K-1503 Neutralization Pit, and

The Zone 2 ROD required land use controls to prevent disturbance of soils below $10 \mathrm{ft}$ deep and to restrict future land use to industrial/commercial activities. In response to stakeholder comments, the U.S. Department of Energy agreed to re-evaluate the need for such land use restrictions. This document includes a screening evaluation to determine the likelihood of land use controls in EU Z2-36 being modified to: (I) eliminate the restriction on disturbance of soils below $10 \mathrm{ft}$ bgs where data indicate the absence of residual contanination at any depth that would result in an unaoceptable risk to the future industrial worker, and (2) permit alternative land uses that would be protective of future site occupants. Results of this screening evaluation indicate a low probability that restrictions on disturbing soil below $10 \mathrm{ft}$ bgs could be safely elinirated for EU Z2-36. A qualitative screening evaluation considered the likelihood of unrestricted land use being protective of future site occupants. Based on this qualitative assessment, all 15 acres addressed in this PCCR wete assigned a low probability for consideration of release for unrestricted land use. 
This document contains the main text (Sects. 1 through 13) and one appendix. The main text addresses the purposes for this PCCR. Additional supporting detail (e.g., field work summaries, maps, survey results, and data summaries) is provided in the EU Z2-36 technical memorandum (Appendix A). Historical and DVS analytical data used in this PCCR are provided on a compact dise attached to this document and can be accessed through the Oak Ridge Environmental Information System. 


\section{INTRODUCTION AND PURPOSE}

The purpose of this Phased Construction Completion Report (PCCR) is to present fiscal year (FY) 2009 results of Dynamic Verification Strategy (DVS) characterization activities for exposure unit (EU) Z2-36 in Zone 2 at the East Tennessee Technology Park (ETTP). The ETTP is located in the northwest comer of the U.S. Department of Energy (DOE) Oak Ridge Reservation in Oak Ridge, Tennessee and enconpasses approximately 5000 acres that have been subdivided into three zonesZone 1 ( $~ 1400$ acres), Zone 2 ( -800 acres), and the Boundary Area ( 2800 acres).

Zone 2 comprises the highly industrialized portion of ETTP (Fig, 1) and consists of all formerly secured areas of the facility, including the large processing buildings and direct support facilities; experimental laboratories and chemical and materials handling facilities; materials storage and waste disposal facilities; secure document records libraries; and shipping and receiving warehouses. The Record of Decision for Soil, Buried Waste, and Subsurface Structure Actions in Zone 2, East Tennessee Technology Park, Oak Ridge, Tennessee (DOE 2005) (Zone 2 ROD) specifies the future end use for Zone 2 acreage as unconirolled industrial for the upper $10 \mathrm{ft}$ of soils.

Characterization activities in these areas were conducted in compliance with the Zone $2 \mathrm{ROD}$ and the DVS and data quality objeclives (DQOs) presented in the Main Plant Group DQO Scoping Package (July 2006) and the Remedial Design ReportRemedial Action Work Plan for Zone 2 Soils, Slabs, and Subsurfoce Structures, East Tennessee Technology Park, Oak Ridge, Tennessee (DOE 2007a) (Zone 2 RDR/RAWP). The purpose of this PCCR is to address the following:

- Document EU Z2-36 DVS characterization results;

- Describe and document the risk evaluation and determine if the EU meets the Zone 2 ROD requirements for unrestricted industrial use to $10 \mathrm{ft} b \mathrm{gs}$, and

- Identify additional areas not defined in the Zone 2 ROD that require remediation based on the DVS evaluation results

The Zone 2 ROD divided the area into 7 geographic areas and 44 EUs. To facilitate DQOs of the DVS process, the Zone 2 RDR/RAWP regrouped the 44 EUs into 12 DQO scoping EU groups. These groups facilitated the DQO process by placing similar facilities and their support facilities together and allowing identification of data gaps. The EU groups were no longer pertinent after DQO planning was completed, and characterization was conducted as EUs became accessible. As the opporturity to complete characterization became available, the planned DVS program was completed in FY 2009 for EU Z2-36. 


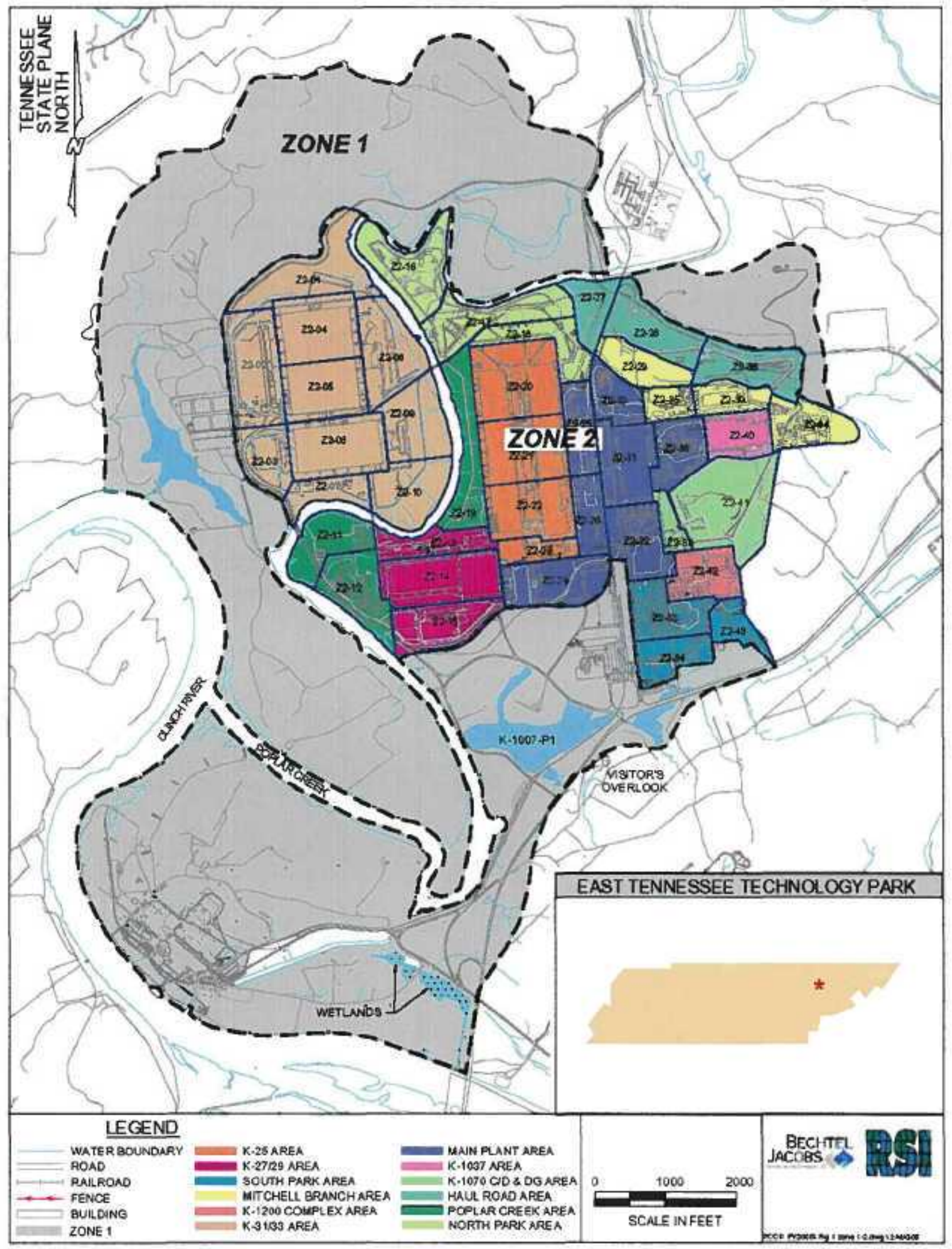

Fig. 1. ETTP site map with Zone 2 DQO scoping EU groups and EUs. 
The main body of this report describes the DVS process and the scope of work performed. The scope and approach for performing DVS activities that lead to action/no further action decisions are presented in Sects. 2 through 4 . The remedial action of backfilting the building K-150l basement and two small adjacent pits, notmally described in Sects. 5 through 10, was described in Fiscal Year 2007 Phased Construction Completion Report for the Zone 2 Soils Slabs, and Subsurface Structures at East Tennessee Technotogy Park, Oak Ridge, Tennessee (DOE 2007b). Future land use is described in Sect. 11, and the status of all Zone 2 EUs as of this PCCR is presented in Sect. 12. 


\section{PROJECT DESCRIPTION}

\subsection{SCOPE}

\subsubsection{Exposure Unit Groups}

The Zone 2 ROD specified the division of Zone 2 into 44 EUs that range in gize from 5.9 acres (EU Z2-37) to 38 acres (EU Z2-41). The location of EU Z2-36 in the Main Plant Area is shown in Fig. 2. An EU represents a hypothetical area over which an industrial worker could be exposed to contaminated soil in the interval 0 -10 ft bgs. The acreage of each EU was calculated based on the estimated EU boundaries defined in the Zone 2 ROD. For the Zone 2 DVS characterization program, EU boundaries and acreage calculations were refined. Acreages presented in this document have been rounded to one decimal place.

To facilitate DQO development and planuing, the 44 EUs within Zone 2 were divided into $12 \mathrm{EU}$ Groups (DOE 2007a). Field activities were conducted as the opportunity for access to the various areas arose. Coordination between deactivation and demolition (D\&D) activities and assets utilization priorities were the primary drivers in executing the Zone 2 DVS characterization program and RAs. Therefore, EU groups were not completed in their entirety. Evaluation and discussion of the DVS program completed in EU Z2-36 is provided in the technical memorandum (TM) (see Appendix A). The Zone 2 EU groups, EUs, and associated total EU group acreages are shown in Table 1.

Thble 1. Zone $2 \mathrm{EU}$ groups and acreages

\begin{tabular}{|c|c|c|}
\hline EU Group & EUs & Acreage \\
\hline $\mathrm{K}-31 / \mathrm{K}-33$ Avea & $\begin{array}{l}\mathrm{Z} 2-01, \mathrm{Z2}-02, \mathrm{Z2}-03, \mathrm{Z2}-04, \mathrm{Z2}-05, \mathrm{Z2}-06, \mathrm{Z2}-07, \overline{\mathrm{Z} 2-08,} \\
\mathrm{Z2}-(09, \mathrm{Z2}-10\end{array}$ & 223.6 \\
\hline Poplar Creek Area & $\mathrm{Z} 2-11, \mathrm{Z2}-12, \mathrm{Z2}-19$ & 58.5 \\
\hline K-27/K-29 Area & $22-13,22-14, Z 2-15$ & 60.5 \\
\hline North Park Area & $Z 2-16, Z 2-17, Z 2-18$ & 62.9 \\
\hline K-25 Arted & $\mathrm{Z} 2-20, \mathrm{Z} 2-21, \mathrm{Z} 2-22, \mathrm{Z} 2-23$ & 87.6 \\
\hline Main Plant Area & $\mathrm{Z} 2-24, \mathrm{Z} 2-25, \mathrm{Z2}-26, \mathrm{Z2}-31, \mathrm{Z2}-32, \mathrm{Z2}-36$ & 100.9 \\
\hline Haul Road Area & $\mathrm{Z2}-27, \mathrm{Z2}-28, \mathrm{Z} 2-38$ & 52.3 \\
\hline Mitchell Branch Area & $\mathrm{Z} 2-29, \mathrm{Z} 2-30, \mathrm{Z} 2-35, \mathrm{Z2}-39, \mathrm{Z2}-44$ & 59.7 \\
\hline K-1037 Area & $\mathrm{Z} 2-40$ & 13.8 \\
\hline $\mathrm{K}-1070-\mathrm{CD}$ and Downgradient Area & $Z 2-37,22-41$ & 44.0 \\
\hline K-1200 Complex Area & $\mathrm{Z} 2-42$ & 15.5 \\
\hline \multirow[t]{2}{*}{ South Park Area } & $Z 2-33, Z 2-34, Z 2-43$ & 39.7 \\
\hline & Total acreage & 819.0 \\
\hline
\end{tabular}

ELl = exposure unit 


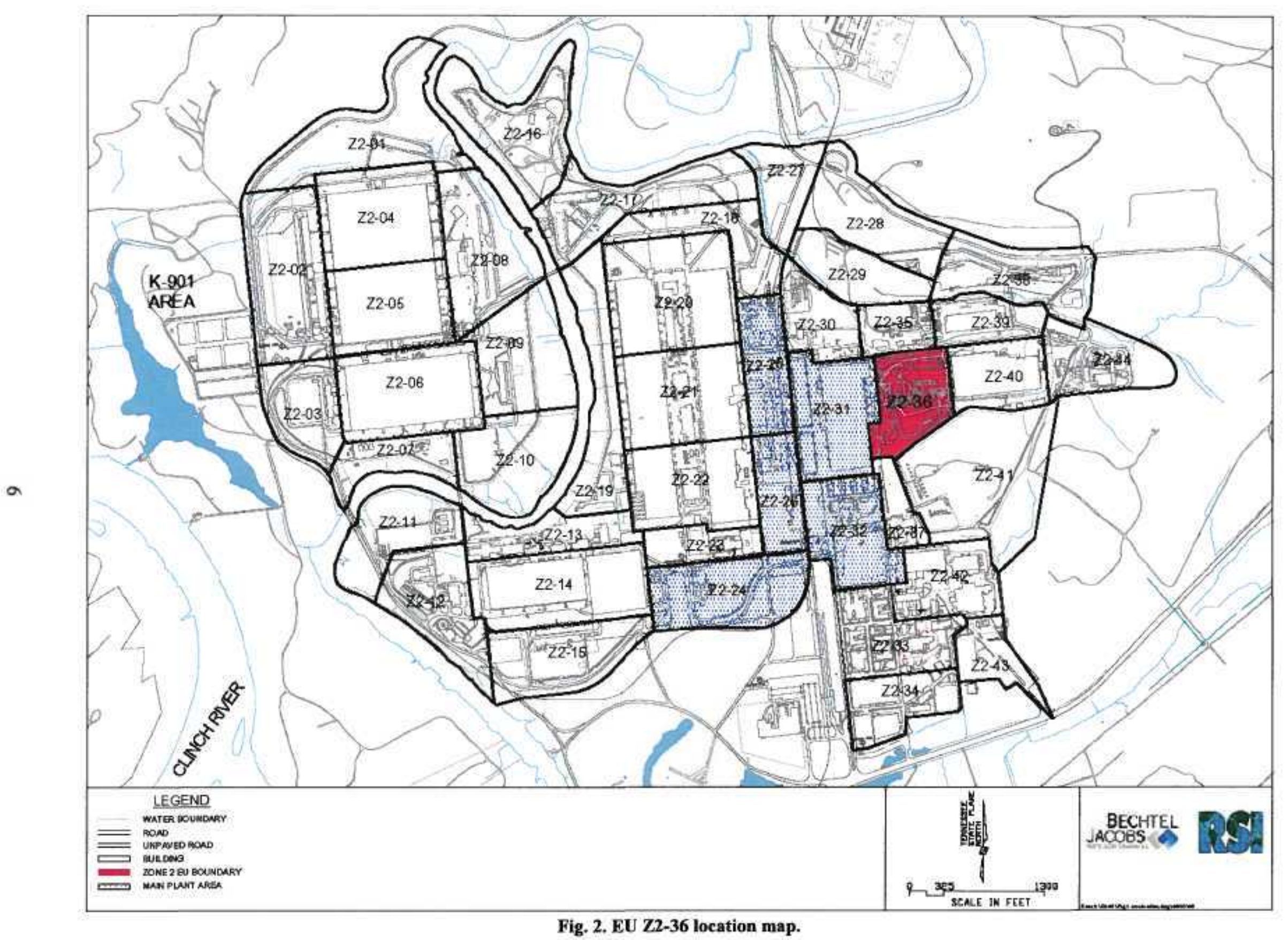




\subsubsection{Ercluded Acreage}

No EU Z2-36 acreage is excluded. All acreage in EU Z2-36 discussed in this document is included in its entirely.

\subsubsection{Data Quality Objectives and Soil Unit Classifications}

The first action taken under the DVS characterization program was to assemble the DQO scoping packages, which are Core Team documents that give a compilation and evaluation of facility records and present the results of previous sampling that provided the bases for soil unit (SU) classification and determination of additional sampling needs. The Multi-Agency Radiation Survey and Site Investigation Manual (MARSSIM), which describes the probability that an area has been impacted and the extent to which the impact forms the basis for classification, was generally followed for SU classification. The SU classification was used to develop a graded approach to the level of scrutiny so that soils with the highest probability of contamination teceived the highest level of scrutiny and those with the lowest probability of contamination received the lowest level of scrutiny. The SUs were classified as follows:

- Class 1 -high to moderate probability that contaminants exceed remedial action objectives (RAOs),

- Class 2 -moderate to low probability that contaminants exceed RAOs,

- Class 3-impacted areas with low probability of contamination above RAOs, or

- Class 4-no impact from anthropogenic activities (no Class 4 SU areas were identified in Zone 2).

The soil classification breakdown for acreage in EU Z2-36 included the following:

- 0 acres in Class I SUs,

- 2 acres in Class 2 SUs,

- 13 acres in Class 3 SUs, and

- $\quad 0$ acres in Class 4 SUs.

In each case, the probability of contanination was based on a thorough review of historical data, aerial photographs, records, and personnel interviews. Soil sampling activities under the DVS included both the Class 2 and Class 3 SUs. The SUs were evaluated by walkover assessments, which included historic photograph analysis, records research, visual inspection, limited radiological survey, and selected biased sampling based on walkover assessment observations and measurements.

\subsubsection{Federal Facility Agreement Sites}

There are two Federal Facility Agreement (FFA) sites (DOE 1992) in EU Z2-36 that are assessed in this PCCR. Final status assessments for these sites are summarized in Table 2.

\subsection{DVS CHARACTERIZATION APPROACH}

The DVS approach to soils characterization and the rationale to support conclusions drawn from the characterization results are presented in this section. Through characterization activities, DVS provides the necessary information to support decisions on whether an action is required. Additionally, DVS supports decisions on the extent of an action and, through confirmation sampling, whether the action is 
Table 2. FFA sites in EU Z2-36

\begin{tabular}{lccc}
\hline \multicolumn{1}{c}{ FFA site } & EU & $\begin{array}{c}\text { Final status ossessed } \\
\text { in this PCCR? }\end{array}$ & Explanation, if not assessed \\
\hline K-1098-C Asphalt Plant & Z2-36 & Yes \\
K-1503 Neutralization Pit & Z2-36 & Yes
\end{tabular}

EU 1 exposure unit

PCCR = Phased Construction Completion Repont

FFA = Federal Facility Agetment $\quad \mathrm{RCW}=$ recirculating cooling water

complete. In this section, the characterization approach and communications necessary to make key decisions throughout the DVS process are discussed. Decisions and communications required during remediation also are discussed. The DVS process was further defined in the Zone 2 RDR/RAWP (DOE 2007b).

The DVS process was designed to provide sufficient data to deternine if a RA is needed. To meet this goal, a sampling strategy was developed based on the likelihood of RA being required. The DVS characterization approach has six key components, which include the following:

- Planning (Sect. 2.2.1), including acreage classification (Sect 2.2.1.1) and DQO scoping (Sect. 2.2.1.2);

- Class 1 and Class 2 SU characterization approach (Sect. 2.2.2);

- Class 3 and Class 4 SU characterization approach (Sect. 2.2.3);

- Prograrn execution (Sect. 2.2.4);

- Action'no further action (NFA) decision/conmunication (Sect. 2.2.5); and

- Documentation and records (Sect. 2.2.6).

During the planning stage (first component), the actes of interest were classified into SUs according to their potential level of contamination as described in Sect. 2.1.3, and the DQOs were applied to develop a sampling plan. Because of different probabilities for the presence of contamination, SU classifications had different characterization strategies (second and third component). However, a brse survey and sampling program was developed for all SU elessifications and presented during DQO scoping. This base program was modified during field implementation as work was conducted and additional characterization needs were identified. The Class 1 and Class $2 \mathrm{SU}$ base program consisted of radiological walkover and geophysical surveys, where appropriate, and systematic sampling supplemented by biased sampling. The Class 3 and Class $4 \mathrm{SU}$ base program primarily consisted of visual inspections and radiological sereening surveys with biased sampling conducted based on inspection and survey observations. Execution techniques to accomplish SU characterization were carried out in the field (fourth component). The final stage included RA Core Team decision making and communication, which was associated with ail sampling programs (fifth component).

The RA Core Team was created to streamline planning and accelerate the completion of all actions at ETTP to accelerate site closure. The RA Core Team approach is a formalized, consensus-based process where members reach agreement on key closure issues and strategies. The RA Team consists of representatives from parties to the FFA-DOE, U.S. Environmental Protection Agency (EPA), and Tennessee Department of Environment and Conservation (TDEC) as well as DOE's accelerated closure contractor. The prinary function of the RA Core Team is to make programmatic decisions that facilitate and guide specific projects as ETTP progresses toward closure.

The following subsections provide an overview of the first four DVS characterization process components. 


\subsubsection{Planning}

The two key parts of the planning component included soil unit classification and DQO scoping for sampling plan development, both of which required RA Core Team concurrence.

\subsubsection{SU classification}

To begin planning, the land area within each EU Group was classified as either impacted or non-impacted by ETTP plant activities. This initial classification included compilation and review of existing information from historic aerial photographs, maps, drawings, and other facility records. After classification as impacted/non-impacted, land areas were assigned SU ciassifications as defined in Sect. 2.1.3. (FFA sites were typically designated as Class 1 or Class 2 SUs.)

\subsubsection{DQO scoping}

Once the area under consideration was classified into a SU, the quantity and quality of existing data and other information was evaluated against the DQO requirements for sufficiency and quality, and a DQO scoping plan for base program surveying, sampling, and analysis was developed. Some of the work described below (e.g., field survey results) was used to design the DQO scoping plan and was considered part of the planning process. A DQO scoping plan, including the SU classifications, was presented to the RA Core Team for concurrence and documented in the Dynamic Work Plan (DWP), which identified sample locations and analysis requirements, and included the use of real-time field measurements where applicable. Any additional samping and analysis was added to the program with RA Core Team concurrence. The DQO scoping meeting for work described in this PCCR was conducted on January 19, 2005, and the applicable DWP is the Zone 2 Dynamic Work Plan, East Tennessee Technology Park, Oak Ridge, Tentessee (BJC 2007).

Per the DVS process, a portion of characterization samples were analyzed for as extensive list of potential contaminants. Fixed laboratory analyses were performed for a suite of analytes [volatile organic compounds (VOCs), semivolatile organic compounds (SVOCs), target analyte list (TAL) metals, polychiorinated biphenyls (PCBs), and a radiological analytical suite that included gamma spectroscopy, alpha spectroscopy, thorium-isotopic, uranium-isotopic, technetium-99, and radium-specific analyses].

All identified contamination was evaluated to determine if action was needed for the EU, including the following:

- Primary and secondary contaminants of concern (COCs), which are identified in the Zone 2 ROD;

- Contaminants of potential concern, which are identified during the tisk evaluation process; and

- EU-specific COCs, which are contaminants identified during characterization that result in an unacceptable EU risk.

The documentation included a summary of existing data, assessment of data gaps in DQO scoping packages, and documentation of the base survey and sampling program in the Zone 2 DWP. Concurrence on the base program was reached by the Core Team and documented on concurrence forms.

\subsubsection{Class 2 SU Characterization Approach}

Implementation of the Class 2 SU characterization program included the steps listed below. Details on each step are provided in Sect. A.8 of the Quality Assurance Project Plan for Soil Characterization Activities under the Dynamic Verification Strategy at the East Tennessee Technology Park, Oak Ridge, Tennessee (QAPP), which is inciuded as Appendix A in the Zone 2 RDR/RAWP (DOE 2007a). 
- Step 1 (not applicable in Zone 2)-Complete an ecological impact assessment prior to significant disturbance.

- Step 2 (not applicable in Zone 2) —Clear to provide access (as required).

- Step 3-Perform radiological walkover surveys (where historic surveys are unavailable) and geophysical surveys [burial sites and underground storage tank (UST) sites].

- Step 4-Select systematic sampling locations and additional biased sampling locations based on survey results.

- Step 5-Perform base program and initial biased sampling.

- Step 6-Evaluate field and laboratory data.

- Step 7-Select additional biased sampling locations based on field measurements and laboratory results.

A flow diagram outlining the details of this characterization approach and associated decisions made for Class 2 SUs is shown in Fig. 3. Along with the planning component (acreage classification and DQOs) defined in Sects. 2.2.1.1 and 2.2.1.2, Steps 1 through 4 above constitute the base program for characterizing Class 2 SUs.

Field radiological and geophysical surveys (Step 3) were performed prior to the actual sampling activity. A lead time of several weeks to months allowed for the evaluation of survey data and supported selection of a set of biased sampling locations to evaluate the results. Geophysical surveys were used to define the boundaries of buried waste at landfill disposal sites or the presence of other buried objects (USTs) and materials.

Radiological walkover surveys were used to define the limits of radiological contamination in surface soils. The decision to have biased sampling locations where elevated radiological readings or geophysical anomalies were encountered (Step 4) was made after reviewing results of the radiological walkover and geophysical surveys. (These survey results were used later during the confimation sampling phase to assist in identifying potential excavation boundaries.) After concurence from the RA Core Team, any biased sampling locations identified from these survey results were included in the base sampling program.

Characterization field work began (Step 5) after the base program was defined and agreed to by the RA Core Tearn. Each EU Group was characterized according to the specific details presented during DQO scoping and finalized in the DWP. Soil sampling was performed using standard field methods and following EPA Region IV standard operating procedures (SOPs).

The predominant method of sample acquisition for subsurface soil to depths up to $30 \mathrm{ft}$ was Geoprobe $\mathbb{B}$ sampling. Surface and shallow interval soil sampling was performed predominantly using hand augers. The standard DVS sampling methodology calls for composite samples to be taken from the 0- to 6-in interval, 6-in. to 2-ft interval, and 2- to 10-ft interval. The sample composite protocol is presented in Attachment $C$ to the QAPP [Appendix A in the Zone 2 RDR/RAWP (DOE 2007a)]. Discrete interval samples were collected based on the following two criteria (Steps 5,6, and 7):

- Field screening method showed an elevated level for a COC in a segment of a core; or

- Initial analytical results from samples submitted to a laboratory showed an action level [25\% of an average remediation level (ARL)] for one or more COCs was exceeded in the composited sample (Steps 6 and 7). 


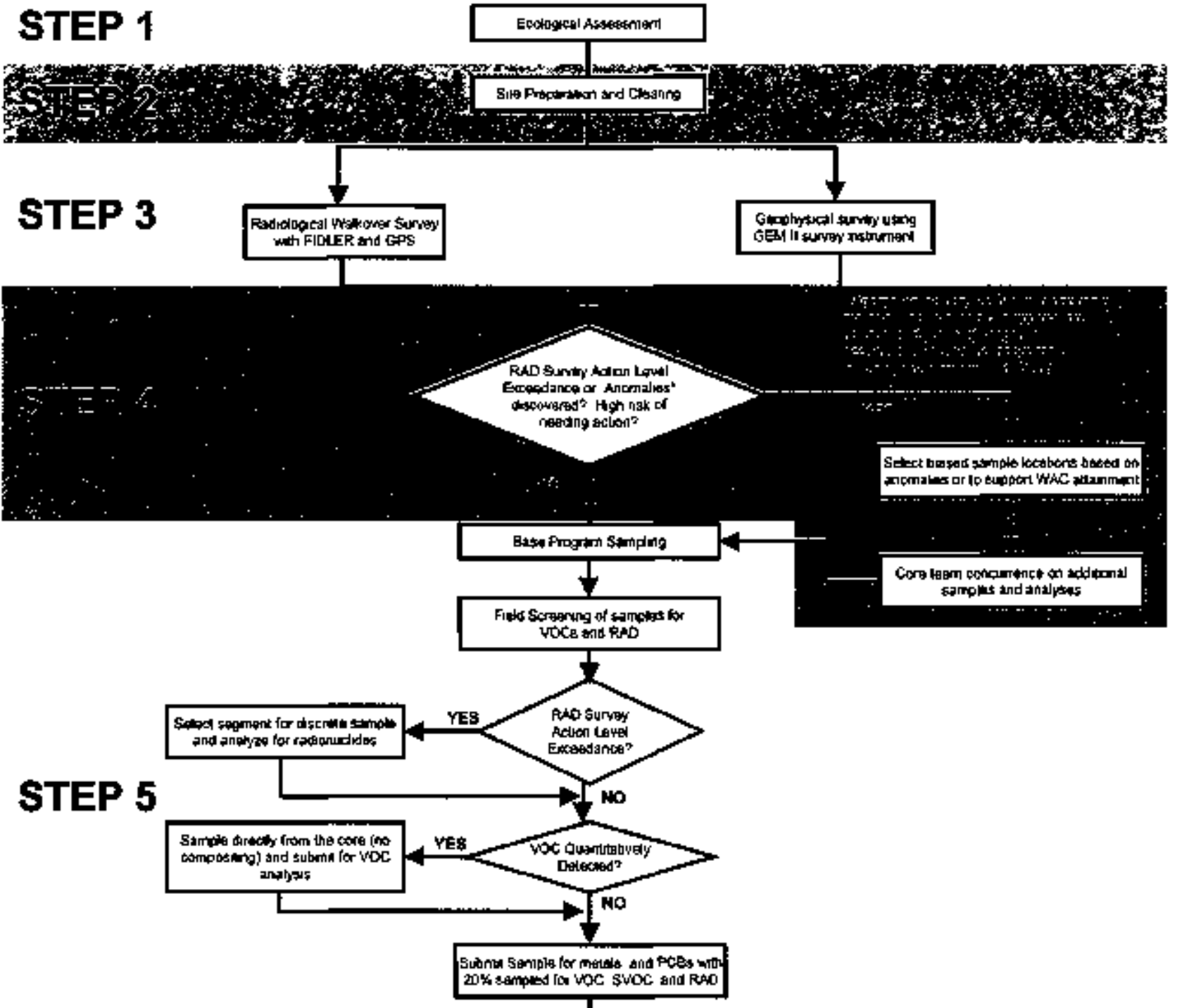

\section{STEP 6}

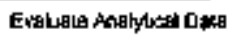

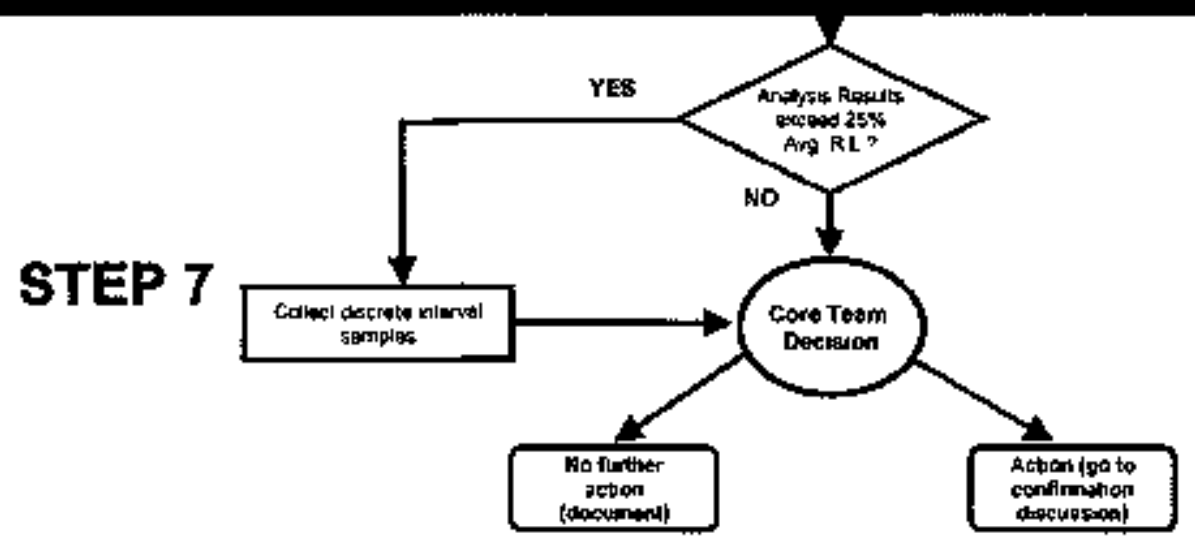

RIg. 3. Zone 2 DVS Class 1 and Class $2 \mathrm{SU}$ sampLing and analysts decision process flow. 
For the first criterion, field screening methods were used as part of the field characterization activity (Step 5). Two field screening methods used on soil cores included (1) VOC screening using hand-held meters, and (2) radiological seteening using core-scanning devices developed specifically for the DVS program. Field screening allowed sample collection for laboratory analysis of the core intervals most likely to have contamination in addition to collection of the composited sample. Collection of the most-likely contaninated segment of the core ensured existing contamination was represented in the analytical results. Recognition of potential VOC contamination also allowed the segment of the core to be collected for VOC analysis prior to compositing. VOCs were not analyzed for in composite samples.

The second criterion was based on analysis of laboratory results. The base program required all samples to be atalyzed for TAL metals and PCBs. To support the risk assessment, a randomly selected $20 \%$ of all samples also were analyzed for VOC (discrete interval), SVOC, and radjological analyses (Step 5). If laboratory-reported results indicated action levels were exceeded in any of the randornly selected samples, the location with elevated results was resampled for the specific parameters of concern and three discrete intervals [0-6 in, 6 in. $-2 \mathrm{ft}$, and a selected interval in the 2-10 $\mathrm{ft}$ interval (Steps 6 and 7)] were sent for analysis.

Current EPA laboratory analytical methods were used to provide risk assessment quality data as required by the DQO process and as stipulated in the DWP for all composite samples, discrete samples, and samples sent for full-suite analysis. All of the information collected is documented in the EU Z2-36 TM (Appendix A).

\subsubsection{Class 3 SU Characterization Approach}

A flow diagram outlining the characterization approach taken and the associated decisions made for Class 3 and Class 4 SUs is presented in Fig. 4 . Note that no Class 4 SUs are present in EU Z2-36. The following statements were considered during decision making:

- Are there anthropogenic features, areas of elevated radiation, or sediment accumulation areas that require biased sampling and analysis?

- Does the EU exceed RAOs stated in the Zone 2 ROD and, therefore, require action? (Results from Class 1 and 2 SU evaluations, if applicable, are needed to make this final EU-level assessment.)

Assessment of the Class 3 and Class 4 SU acreage proceeded independently of the Class 2 SU investigations and were performed during the winter, when possible, to facilitate inspection of those portions of Zone 2 with heavy vegetation. These assessments were conducted in accordance with the Class 3 and Class 4 Soil Unit Walkover Assessment Protocol (DOE 2007a, Attachment C). The approach began with visual walkover inspections conducted to systematically inspect Class 3 SUs along transects to established systematic grid assessment locations, map observed features, and collect radiological screening data to support the action/NFA dexision.

These assessments focused on identifying anthropogenic features, delineating boundaries of the features, and determining if sampling of the fealures was warranted. Anthropogenic features identified in the Class 3 SU were broadly inclusive of anything present as the result of any human activity. Identifying any unnatural conditions in the remote areas of the site where little to no industrial activity occunred was a very conservative approach to the site assessment protocol for cleating large tracts of peripheral lands in Zone 2. Anthropogenic features as defined in the Class 3 and Class 4 SU walkover assessment protocol were to include areas of radiation survey anomalous readings (above two times area background), visible anthropogenic materials (such as concrete, asphalt, metal debris, rubble, and rubbish), soil staining or discoloration, andior stressed vegetation. In addition, crews were instructed to identify areas of unusual topographic relief, low areas where sediment would accumulate, and mounds of soil that appeared to be unusual for the local topographic conditions. This very broad definition of anthropogenic features provided a thorough assessment of the Class $3 \mathrm{SU}$ in EU Z2-36. 


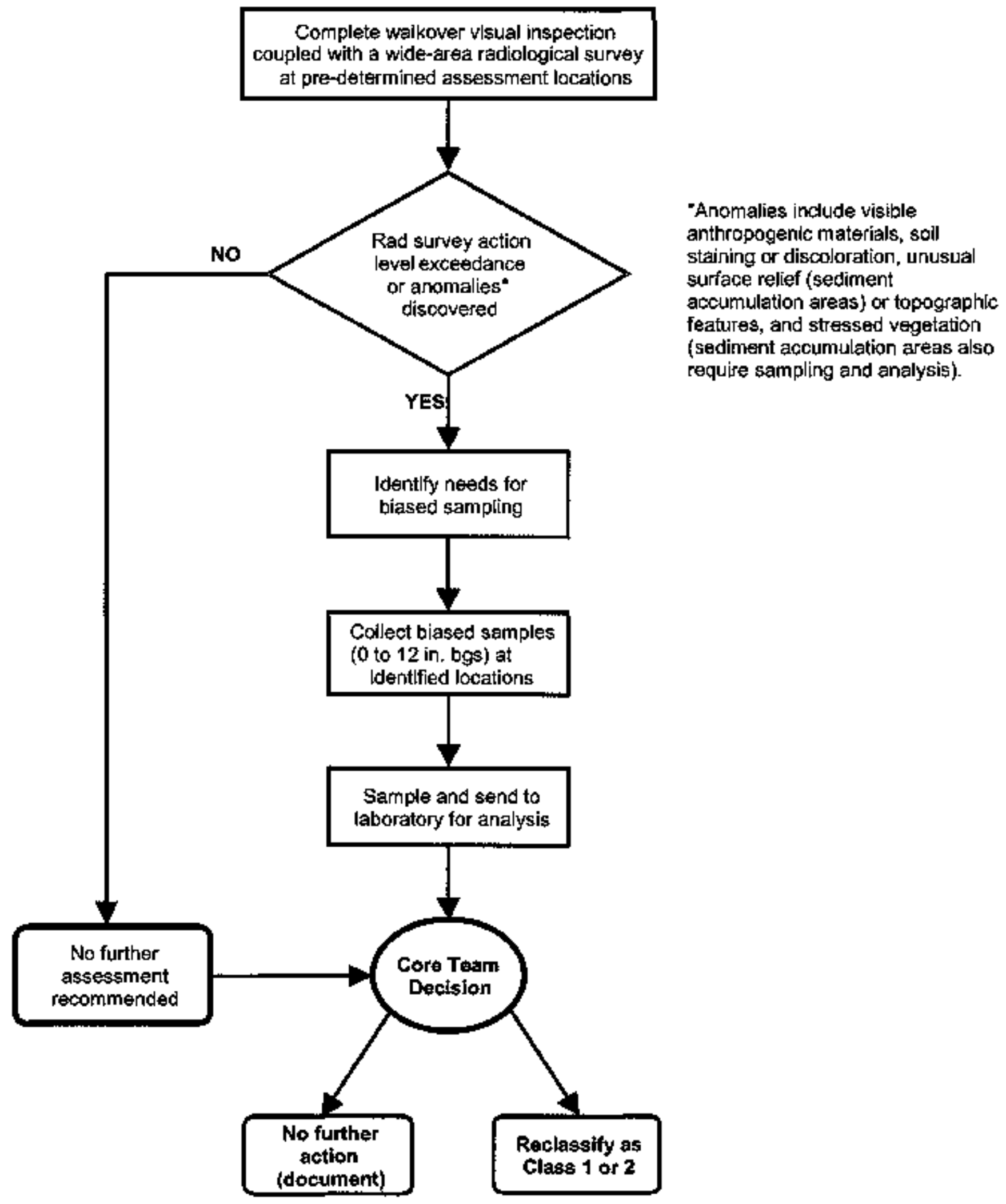

Fig. 4. Zone 2 DVS Class 3 and Class 4 SU sampling and analysis decision process flow. 
A systematic grid with a random starting point was used to establish each assessment point (AP), with approximately one point per acre. A field instrument for detection of low-energy radiation (FIDLER) (Ludlum(8) 44-17 detector, $2 \mathrm{in} . \times 2 \mathrm{~mm}$ ) was used by the survey crews. Background conditions were established for the EU group based on the Class 3 and Class 4 Soil Unit Walkover Assessment Protocol (DOE 2007a, Attachment C). The screening level (SL), which determined the need for further consideration and detailed evaluation, was twice the group mean background value. Approximately hatfway to each AP, a mid-point (MP) was counted and surface features described. A Class 3 SU radiological survey was conducted at APs, MPs, and discretionary points during the SU walkover assessments. Anthropogenic features or areas of elevated activity away from APs and MPs were also characterized with 30-second counts of the FIDLER as a discretionary survey point.

Biased soil samples from identified anomalies were collected and analyzed for metals, radionuclides, and PCBs. Approximately $20 \%$ of the biased samples were analyzed for a larger suite of analytes to ajd in identifying potentially unrecognized, site-related soil contaminants.

Biased sampling locations alșo were identified in sediment accummlation areas, which are defined as areas where runoff from large portions of the $\mathrm{SU}$ and surrounding areas converge and have the potential for sediment deposition. The chemical and radiological composition of sediment accumulation area soils or sediments is representative of the upstream conditions, and elevated levels of contamination are indicative of an upgradient source. Biased samples collected from sediment accumulation areas were sent to a laboratory for radionuclide, metal, VOC, SVOC, and PCB analysis to identify previously unrecognized site-related soil contaminants.

\subsubsection{Program Execution}

Soil sample collection was performed following EPA Region IV standard sampling methods and SOPs. The DVS base program sampling was tailored to site-specific conditions and samples were collected in the 0 - to $10-\mathrm{ft}$ depth in all Class 1 and Class 2 SUs. There were several conceptual site models in Zone 2 that included surface and subsurface models describing the potential contaminant source and potential release to the environment.

The DVS program for the Class I and 2 SUs required at least $20 \%$ of all sample locations be drilled and sampled to a depth of 10 ft bgs. Sample borings were completed using Geoprobeti direct-push equipment (Models 54DT and 54LT) and were collected in acetate liners and capped upon recovery. All boreholes were logged and described according to EPA Region IV guidance (EPA 2002), and all soil cores were scanned in the field for the presence of radioactive contaminants using the Model $T$ Radiological Soil Core Screening System. The core screening action level was set to conrespond with approximately $80 \%$ of the ARL for $U-238(40 \mathrm{pCi} / \mathrm{g})$. The SL for the core scanner was based on a background soil core for which a daily baseline value was determined. The SL varied slightly from day to day in response to local ambient radiological conditions and natural activity of the background soils specific for the EU Group. Sereening levels were set at the observed daily baseline (commonly in the range of $135-150 \mathrm{cpm})$, plus $65 \mathrm{cpm}$, and were in the range of $200 \mathrm{cpm}( \pm 20 \mathrm{cpm})$, which provided $100 \%$ accuracy for identifying gamma-emitting radioactive contamination in soils in excess of $40 \mathrm{pCi} / \mathrm{g}$.

Results of field activities completed in this PCCR indicate the SLs of baseline plus $65 \mathrm{cpm}$ were consistently identifying radiological constituents at $10 \mathrm{pCi} / \mathrm{g}$ or greater in soil cores. When the SL was exceeded, a discrete interval soil sample was collected for radiological analysis.

The acetate liners were split in the field and the core was screened for the presence of VOCs. If VOCs were detected above $5 \mathrm{ppm}$ using a hand-held photoionization detector, a discrete interval soil sample was collected for VOC analyses using EnCoreB samplers. Approved sample containers were used at these sites and managed according to EPA Region IV protocols (EPA 2002).

At base program sampling locations, three intervals of the soil core were composited according to the protocol described in the QAPP (DOE 2007a, Appendix C). The compositing procedure stipulates that 
equal volumes of soil from the surface to 0.5 -ft interval, 0.5- to 2-ft interval, and a selected section of core in the 2 - to 10 - $\mathrm{ft}$ interval be collected and thoroughly mixed to form a composite soil sample. The interval selected for inclusion in the soil composite was based on visual observation of the sample and targeted to select the most contaminated portion of the soil core. Selection was made based on visual observations such as staining, odor, soil contacts, obvious waste, or the presence of unnatural materials. This compositing methodology provided a physical composite that represented the average contaminant profile for the entire 0- to 10-ft interval. All base program composite samples were analyzed for PCBs and TAL metals and screened in the field for the presence of VOCs $>5 \mathrm{ppm}$ ) and radioactivity (in excess of two times background). Discrete interval samples were collected for VOC and radiological analyses if field SLs were exceeded [refer to the Zone 2 QAPP (DOE 2007a) for specific procedures].

The DVS progam requires $20 \%$ of all sample locations be trilled and sampled to $10 \mathrm{ft}$ bgs. At surface contamination sites, the base ptogram focused on the 0 - to $2+\mathrm{ft}$ interval where contaminant releases would have occurred. However, $20 \%$ of the locations wete drilled and sampled to $10 \mathrm{ft}$ bgs. At the UST sites and buried utilities and infrastructure sites, all borings were drilled and sampled to $10 \mathrm{ft}$ bgs or to native material, whichever was deeper. The program also requires at least $20 \%$ of all samples be analyzed for a full suite of COCs, including VOCs, SVOCs, metals, PCBs, and radiojsotopes. Locations to be drilled to depth and samples for full suite analyses are randomly selected. This selection ptocess results in full suite analyses being performed on both surface and shallow interval samples as well as on some deep soil samples.

Changes to the base program plan included dropping inaccessible sample locations (e.g., areas of steep slopes or obstructions such as roads or heavy dead fall areas) and moving locations due to shallow refusal (e.g-, butied concrete and metallic debris and rubble). These changes were documented on concurrence forms and presented to the Core Team for concurrence. Drops and moves occurred at $<5 \%$ of the planned locations. Locations moved more than $5 \mathrm{ft}$ from the planned grid node were identified by the inclusion of an "M" character in the location ID (e-g. Z2-EU36M-200).

At surface contamination sites, the base program plan stipulated sampling the 0 - to 2 - $\mathrm{ft}$ interval to focus in the interval where contamination levels were assumed to be the highest. Sampling in these areas was performed using the Geoprobe(t) equipment and 0- to 2-th, two-interval composite samples using the standard sampling method. In these areas, $20 \%$ of the base program sample locations were drilled to $10 \mathrm{ft}$ at randomly selected locations and $20 \%$ of all locations ( 0 to $2 \mathrm{ft}$ and to depth) were analyzed for a foll suite of constituents. Soil cores at these sites also were screened in the field for VOC and radiological contamination.

Biased sampling was performed in addition to base program sampling. These locations were selected based on the results of geophysical surveys, radiological walkover surveys, and "step-out" locations to base program samples that indicated significant concentrations of contamination occurred. Biased samples drilled to $10 \mathrm{ft}$ were collected in three discrete intervals (from the 0.5 - $\mathrm{ft}$ interval, 0.5- to 2-ft interval, and a selected section of core in the 2 - to $10-\mathrm{ft}$ interval). Surface soil samples were generally collected as five-point composite samples to provide area coverage of radiological surface anomalies, surface-distributed mounds of soils, or small waste piles. The intent of surface compositing was to provide an average contaminant profile for a localized surface area

Sampling procedures and methods were complied using EPA Region IV guidance. Sampling equipment, shipping containers, and quality assurance/quality control (QC) requirements also followed EPA Region IV guidance. Standard laboratory analytical methods were used, and data management and QC procedures were complied with EPA criteria, Detailed discussion of field and laboratory requirements is included in the Zone 2 RDR/RAWP (DOE 2007a). 


\subsubsection{Action/No Further Action Decision/Communication}

Once results of field and analytical work were received, the RA Core Team evaluated the data and decided on an appropriate action. The action/NFA decision was based on one or more of the following criteria:

- Exceedance of a maximum remediation level (RL) at any location,

- Exceedance of an average RL across the EU,

- Unacceptable future threat to groundwater, and/or

- Unacceptable cumulative excess lifetime cancer risk (ELCR) of $>1 \times 10^{-4}$ and hazard index (HI) of $>1$ across the EU.

Sample results were evaluated for the 0 - to 10 -ft soil interval and were not depth dependent. Contamination anywhere within the 0 - to 10 -ft interval had equal weighting in the risk assessment and was presumed equally accessible to an industrial worker. Soil sample compositing provided data representative of the 0 - to 10-ft interval. Discrete interval sampling was selected based on the field screening for VOCs and radioactivity identified by soil core screening. This approach provided a very conservative evaluation of soil conditions and had an equivalent consideration in the risk assessment methodology. Selection of intervals for inclusion in soil core composite samples was based on visual observation and included the portion of the soil core with the highest probability of contamination. Visual cues included but were not limited to bedding contacts, porous and permeable intervals, staining, and odor. Discrete sample interval depth information is included in the data set on the compact disc provided with this docurnent. Major stratigraphic differences (i.e., 2 ft of cover material over fill) are referenced in the text where appropriate.

An area-weighted mean of the data in each EU was used to compare the average composition of the EU to the average RLs. Risk was evaluated by area-weighting the results. Because data within an EU was unevenly distributed across the SUs (i.e., SUs with greater probability of contamination had a higher density of samples), weighting was based on the areal extent of the SUs. For SUs with little probability of contamination and, therefore, few, if any, sample results (i.e., Class 3 SUs), background concentrations of COCs as defined in the Soil Background Supplemental Data Set for the East Tennessee Technology Park, Oak Ridge, Tennessee (DOE 2003) were used in the weighted average calculations for the EU risk assessments and comparison to average RLs.

Data collected for the original background data set for ETTP (DOE 1993a) was not representative of ETTP site soils, nor were the associated statistical calculations performed in accordance with then current EPA guidance. To resolve the issues, additional samples were collected and statistics were recalculated to comply with EPA guidance. Samples were collected from the B soil horizon of the Rome and Upper Knox formations to supplement the original data set. These samples were collected from approximately 12-24 in. bgs and analyzed only for radiological constituents and inorgatic elements. The comparison of site data versus background data was made using methods from Guidance for Comparing Background and Chemical Concentrations in Soil for CERCLA Sites (EPA 2002). Soil background data used in this report was presented in the document Soil Background Supplemental Data Set for the East Tennessee Technology Park, Oak Ridge, Tennessee (DOE 2003) and not from the earlier report.

If elevated concentrations (i.e,, above background) were found, sample results were used (even if sparse) after the SU was reclassitied as a Class 1 or Class 2 SU. Results of the action/NFA evaluation were documented in the EU Z2-36 TM, which were provided to the RA Core Tearn for early review but formally submitted for approval as a appendix to this PCCR. Data, maps, cross sections, and other useful information also were provided on the project webpage to facilitate decision making.

The risk RAO was developed in the Zone 2 ROD to identify new COCs because of the uncertainty that all COCs had been identified in the historical data sets. If the risk assessment identified contaminants 
requiring remediation that did tot have associated RLs, remediation was tecommended if the risk was found to be unacceptable.

\subsubsection{Documentation and Records}

All information, data, documents, and records necessary to support the decisions presented in this PCCR will be transferred to the post-decision document file upon approval of the PCCR. A list of referenced documents that becornes part of the file is provided in Sect. 12. Additional records contained within the file but not listed in Sect, 12 include but ate not limited to FCNs, Core Team concurrence forms, and analytical data packages. FCNs and Core Team concurrences pertinent to EU Z2-36 are listed in Section 6. The post-decision document file is available to the public through the DOE Oak Ridge Office Information Center. Analytical data, field data, and sample location maps are archived in and made available to the public through the Oak Ridge Environmental Information System (OREIS). 


\section{PROJECT REQUIREMENTS}

Requirements for the characterization activities, final status assessments, and RAs originated in the Zone 2 ROD, which presents specific soil RAs required in Zone 2 and provides general guidelines for addressing the remainder of the soils. In response to the guidelines for addressing Zone 2 soils, DVS was developed to present specific requirements for addressing soils and making action/NFA decisions. It is further stated in Sect. 1.5 of the Zone 2 ROD that additional contaminants could be identified during remedy implementation or confimation.

\subsection{ZONE 2 RECORD OF DECISION}

The Zone 2 ROD presents the selected remedy for environmental remediation of contaminated areas within Zone 2 at ETTY. An evaluation of existing data performed in the Zone 2 ROD detemined the following sites either had sufficient characterization data to demonstrate unacceptable risk, warrant additional characterization, and/or selection of an action for soil:

- K-1070-B Old Burial Ground,

- K-1420 Facility Area,

- K-1004-y Lab Complex Area,

- K-1401 Facility Area,

- K-1070-C/D Area, and

- Zone 2 miscellaneous soils.

In addition, the ROD specifies that a DVS should be developed to address the characterization of soils in other areas in the Zone with insufficient data to determine if an action is required. As discussed in the ROD, the key criterion for an action/NFA decision and a successful RA is the RAO, which is presented in Table 3.

Table 3. RAO and protection goals for Zone 2

\begin{tabular}{ll}
\hline \multicolumn{1}{c}{ Remediation issile } & \multicolumn{1}{c}{ Protectlon goal } \\
\hline Future land use & $\begin{array}{l}\text { Protect hurnan health under an unrestricted industrial land use wo a risk level not to } \\
\text { exceed } 1 \times 10^{4}\end{array}$ \\
Groundwater resources & $\begin{array}{l}\text { Control leaching and migration from contaminated soil to belp minimize further } \\
\text { impacts to groundwater }\end{array}$ \\
\hline
\end{tabular}

RAO = remedial action objective

Other key parts of the ROD include determining future land use as unrestricted industrial to $10 \mathrm{ft}$ bgs, protecting the industrial worker front soil exposure identified as the primary risk driver, developing a risk assessment methodology based on EUs, and defining soil COCs with corresponding soil RLs (two $R L s$ were established for each COC in the ROD). The maximum $R L$ is the concentration that a COC may not exceed at any location within an $\mathrm{BU}$. The average $R L$ is the average $C O C$ concentration within an $\mathrm{EU}$ that, when exceeded, means the RAO risk protection goal has not been met. The Zone 2 ROD COCs, chemicals, and radionuclides required for analysis and associated RLs are presented in Table 4. 
Table 4. Chemicals and radionuclides required for analysis in Zone 2 DVS samples and thelr evaluation criteria“

\begin{tabular}{|c|c|c|c|c|c|c|}
\hline $\begin{array}{l}\text { Chemleals and } \\
\text { radionuclides }\end{array}$ & $\begin{array}{c}\text { Marimum } \\
\text { RE }\end{array}$ & $\begin{array}{c}\text { Average } \\
\text { Rl. }\end{array}$ & $\begin{array}{l}\text { Industrlal } \\
\text { PRG (105) }\end{array}$ & Backgranid & $\begin{array}{l}\text { Groundwater } \\
\text { SL }\end{array}$ & $\begin{array}{l}\text { Residential } \\
\text { PRG }\left(10^{-6}\right)\end{array}$ \\
\hline \multicolumn{7}{|c|}{ Metals (mg/kg) (mg/L for groundwater) } \\
\hline Aluminum & & & 100,000 & 40,300 & & $7+614$ \\
\hline Antimonty & & & 410 & 1.52 & 144 & 3.1 \\
\hline Arsenic $^{c}$ & 900 & 300 & 16 & 14.95 & 66.3 & 0.39 \\
\hline Barium & & & 67,000 & 124.93 & 9,150 & 537 \\
\hline Berylliurn & 6,000 & 2,000 & 1,900 & 2.20 & & 15 \\
\hline Boron & & & 100,000 & & & 1,600 \\
\hline Cadmium & & & 450 & $0.22 \mathrm{U}$ & & 3.7 \\
\hline Calcium & & & & 2400 & & \\
\hline Chromium & & & 640 & 44.88 & 172 & 22 \\
\hline Cobalt & & & 130,600 & 42.00 & & 138 \\
\hline Copper & & & 41,000 & 22.48 & & 313 \\
\hline Iron & & & 100,000 & 58,600 & & 2,346 \\
\hline Lead & & & 800 & 37.91 & 3,370 & 400 \\
\hline Lithiurs & & & 20,000 & 48.94 & & 156 \\
\hline Magnesium & & & & 3,300 & & \\
\hline Manganese & & & 19,000 & 2,200 & & 176 \\
\hline Mercuryf & 1,800 & 600 & 310 & 0.17 & & 2.35 \\
\hline Mołybdenum & & & 5,100 & & & 39 \\
\hline Nickel & & & 20,000 & 26.07 & & 156 \\
\hline Potasșium & & & & $5,074,69$ & & \\
\hline Selenium & & & 5,100 & 1.47 & & 39 \\
\hline Silver & & & 5,100 & $0.6 \mathrm{U}$ & & 39 \\
\hline Sodium & & & & 497 & & \\
\hline Thatlium & & & $6 ?$ & $0.4 \mathrm{U}$ & 10.8 & 0.52 \\
\hline Uranium & & & 200 & & & 1.56 \\
\hline Vanadium & & & 1,000 & 65,47 & & 7.8 \\
\hline Zintc & & & 100,000 & 89.70 & & 2,346 \\
\hline \multicolumn{7}{|c|}{ Radionuclides (pCI/g) (ug/L for groundwater) } \\
\hline Cesium- $137^{t}$ & 20 & 2 & 1.1 & & & 0.06 \\
\hline Cobalt-60 & & & 0.6 & & & 0.04 \\
\hline \multicolumn{7}{|l|}{ Gross alpha activity } \\
\hline Grosss beta activily & & & & & & \\
\hline Neptunium-237 $7^{c}$ & 50 & 5 & 2.7 & & & 0.13 \\
\hline Potassium -40 & & & 2.7 & 32.12 & & 0.11 \\
\hline Radium-226 $6^{c, d}$ & 15 & 5 & 0.26 & 1.25 & & 0.01 \\
\hline Technetium-99 & & & 9,000 & & & 0.25 \\
\hline Thorium-230 & 15 & 5 & 210 & 1.20 & & $3 . \overline{5}$ \\
\hline Thorium-232 2 ted & 15 & 5 & 0.176 & 1.95 & & 0.01 \\
\hline Uranium-234, $4^{c}$ & 7,000 & 700 & 330 & 1.47 & 61.1 & 4.02 \\
\hline Uranium-235 $5^{t a t}$ & 80 & 8 & 4.0 & & 61.1 & 0.2 \\
\hline Uranium-238 & 500 & 50 & 18 & 1.47 & 61.1 & 0.74 \\
\hline \multicolumn{7}{|l|}{ Pesticides and PCBs (ug/kg) } \\
\hline PCB-1016 $6^{c}$ & 300,000 & 10,000 & 37,000 & & & 393 \\
\hline PCB- $1221^{\circ}$ & 100,000 & 10,000 & 7,436 & & & 112 \\
\hline PCB-1232 & 100,000 & 10,000 & 7,436 & & & 112 \\
\hline PCB- $1242^{c}$ & 100,000 & 10,000 & 7,436 & & & 112 \\
\hline PCB $-1248^{\circ}$ & 100,000 & 10,000 & 7,436 & & & 112 \\
\hline $\mathrm{PCB}-1254^{*}$ & 100,000 & 10,000 & 7,436 & & & 112 \\
\hline PCB $-1260^{c}$ & 100,000 & 10,000 & 7,436 & & & 112 \\
\hline Polychlorinated biphenyl' & 100,000 & 10,000 & 7,436 & & & 112 \\
\hline
\end{tabular}


Table 4. Chemieals and radionuclides required for analysis in

Zone 2 DVS samples and their evaluation criterla (continued)

\begin{tabular}{|c|c|c|c|c|c|}
\hline $\begin{array}{l}\text { Chemicals and } \\
\text { radionnclides }\end{array}$ & $\begin{array}{cc}\text { Marímum } & \text { Average } \\
\text { RL } & \text { RL } \\
\end{array}$ & $\begin{array}{l}\text { Industriol } \\
\text { PRG }\left(10^{-5}\right)\end{array}$ & Backgriound & $\begin{array}{c}\text { Graundwater } \\
\text { SL }^{6}\end{array}$ & $\begin{array}{l}\text { Residential } \\
\text { PRG (10:5) }\end{array}$ \\
\hline \multicolumn{6}{|c|}{ Semivolatile Organic Componds (n $\mathrm{g} / \mathrm{kg}$ ) (ug/L for groundwater) } \\
\hline 1,2,4-Trichlorobenzene & & 220,000 & & & 6,216 \\
\hline 1,2-Dichlorobenzene & & 600,000 & & & 110,330 \\
\hline 1,3-Dichlorobenzene & & 600,000 & & & 53,135 \\
\hline 1,4-Dichlorobenzene & & 79,000 & & & 3,447 \\
\hline $2,3,4,6-$ Tetrachlorophenol & & $18,000,000$ & & & 183,309 \\
\hline $2,4,5$-Trichlorophenol & & $62,000,000$ & & & 611,031 \\
\hline 2,4,6-Trichlorophenol & & 62,000 & & & 611 \\
\hline 2,4-Dichlorophenol & & $1,800,000$ & & & 18,331 \\
\hline 2,4-Dimethylphenol & & $12,000,000$ & & & 122,206 \\
\hline 2,4-Dinitrophenol & & $1,200,000$ & & & 12,221 \\
\hline 2.4-Dinitrotoluene & & 25,000 & & & 715 \\
\hline 2.6-Dinitrotoluene & & 25,000 & & & 715 \\
\hline 2-Chloronaphthatene & & $23,000,000$ & & & 493,664 \\
\hline 2-Chlorophenol & & 240,000 & & & 6,340 \\
\hline 2-Methyl-4,6-dinitrophenol & & 62,000 & & & 611 \\
\hline 2-Methylnaphthalene & & 190,000 & & & 5,592 \\
\hline 2-MethyIphenol & & $31,000,000$ & & & 305,515 \\
\hline 2-Nitrobenzenamine & & $1,800,000$ & & & 18,277 \\
\hline \multicolumn{6}{|l|}{ 2-Nitrophenol } \\
\hline 3,3'-Dichlorobenzidine & & 38,000 & & & 1,081 \\
\hline 3-Nitrobenzenamine & & 18,000 & & & 1,833 \\
\hline \multicolumn{6}{|l|}{ 4Bromophenyl phenyl } \\
\hline \multicolumn{4}{|l|}{ 4-Chloro-3-methylphenol } & & \\
\hline 4-Chlorobenzenamine & & $2,500,000$ & & & 24,441 \\
\hline \multicolumn{6}{|l|}{ 4-Chlorophenyl phenyl } \\
\hline \multicolumn{6}{|l|}{ ether } \\
\hline 4-MethyIphenol & & $3,100,000$ & & & 310,000 \\
\hline 4-Nitrobenzenamine & & 180,000 & & & 18,330 \\
\hline \multicolumn{6}{|l|}{ 4-Nitrophenol } \\
\hline Acenaphthene & & $29,000,000$ & & & 370,000 \\
\hline Acenaphthylene & & $29,000,000$ & & & 370,000 \\
\hline Aniline & & $3,000,000$ & & & 42,742 \\
\hline Anthracene & & $100,000,000$ & & & $2,200,000$ \\
\hline Benz(a)anthracene & & 21,000 & & & 621 \\
\hline Benzenemethanol & & $100,000,000$ & & & 1,833 \\
\hline Benzo(a)pyтene & & 2,100 & & & 62 \\
\hline Benzo(b)fluroranthene & & 21,000 & & & 621 \\
\hline Benzo(ghiperylene & & $29,000,000$ & & & 231,595 \\
\hline Benzo(k)fluoranthene & & 210,000 & & & 6,215 \\
\hline Benzoic acid & & $100,000,000$ & & & $24,000,000$ \\
\hline \multicolumn{6}{|l|}{$\begin{array}{l}\text { Bis(2-chloroethoxy) } \\
\text { methane }\end{array}$} \\
\hline Bis $(2$-chloroethyl $)$ ether & & 5,800 & & & 218 \\
\hline \multicolumn{6}{|l|}{ Bis(2-chloroisopropyl) } \\
\hline ether & & 74,000 & & & 2,884 \\
\hline Bis(2-ethylhexyl)phthalate & & $1,200,000$ & & $2,350,000$ & 34,741 \\
\hline Butyl benzyl phthalate & & $100,000,000$ & & & $1,200,000$ \\
\hline Carbazole & & 860,000 & & & 24,319 \\
\hline Chrysene & & $2,100,000$ & & & 62,146 \\
\hline Di-n-butyl phthalate & & $62,000,000$ & & & 611,000 \\
\hline
\end{tabular}


Table 4. Chemicals and radionuclides required for amalysis in

Zone 2 DVS samples and their evaluation criteria " (continued)

\begin{tabular}{|c|c|c|c|c|c|c|}
\hline $\begin{array}{l}\text { Chemicals and } \\
\text { radionnuclides }\end{array}$ & $\begin{array}{l}\text { Marimum } \\
\text { RL }\end{array}$ & $\begin{array}{c}\text { Average } \\
\text { RI }\end{array}$ & $\begin{array}{l}\text { Industrial } \\
\text { PRG (10 })\end{array}$ & Backgromend & $\begin{array}{c}\text { Groundwater } \\
\text { SL }^{b}\end{array}$ & $\begin{array}{l}\text { Resdentipi } \\
\text { PRG }\left(10^{-6}\right)\end{array}$ \\
\hline Di-n-octylphthalate & & & $25,000,000$ & & & 244,000 \\
\hline Dibenz(a,h)anthracene & & & 2,100 & & & 62 \\
\hline Dibenzofuran & & & $1,600,000$ & & & 14,526 \\
\hline Diethyl phthalate & & & $100,000,000$ & & & $4,900,000$ \\
\hline Dimethyl phthalate & & & $100,000,000$ & & & $61,000,000$ \\
\hline Diphenykdiazene & & & 160,000 & & & 4,422 \\
\hline Fluoranthene & & & $22,000,000$ & & & 230,000 \\
\hline Fluorene & & & $26,000,000$ & & & 275,000 \\
\hline Hexachlorobenzente & & & 11,000 & & & 304 \\
\hline Hexachlorobutadiene & & & 180,000 & & & 1,833 \\
\hline \multicolumn{7}{|l|}{ Hexachloro- } \\
\hline cyclopentadiene & & & $3,700,000$ & & & 36,550 \\
\hline Hexachloroethane & & & 620,000 & & & 6,110 \\
\hline Indeno(1,2,3-cd)pyrene & & & 21,000 & & & 621 \\
\hline Isophorone & & & $5,100,000$ & & & 512,000 \\
\hline \multicolumn{7}{|l|}{ N-Nitrosondi-n- } \\
\hline propylamite & & & 2,500 & & & 69.5 \\
\hline N-Nitrosodimethylamine & & & 340 & & & 9.54 \\
\hline N-Nitrosodiphenylamine & & & $3,500,000$ & & & 99,261 \\
\hline Naphthalene & & & 190,000 & & & 5,592 \\
\hline Nitrobenzene & & & 100,000 & & & $I, 964$ \\
\hline Pentachlorophenol & & & 90,000 & & & 2,979 \\
\hline Phenanthrene & & & $29,000,000$ & & & 23,160 \\
\hline Phenol & & & $100,000,000$ & & & $1,800,000$ \\
\hline Pyrene & & & $29,000,000$ & & & 231,600 \\
\hline Pyridine & & & 620,000 & & & 6,110 \\
\hline \multicolumn{7}{|c|}{ Volotile Organic Compounds (up/kg) (ute/L for groundwater) } \\
\hline 1,1,1-Trichloroethane & & & $1,200,000$ & & 97,900 & 198,200 \\
\hline 1,1,2,2-Tetrachloroethane & & & 9,300 & & & 408 \\
\hline 1,1,2-Trichlorethane & & & 16,000 & & 1,370 & 729 \\
\hline 1,1-Dichloroethane & & & $1,700,000$ & & & 50,640 \\
\hline I, I-Dichloroethene & & & 410,000 & & 1,750 & 12,350 \\
\hline 1,2-Dichloroethane & & & 6,000 & & 729 & 278 \\
\hline 1,2-Dichloropropane & & & 7,000 & & & 342 \\
\hline 2-Butanone & & & $110,000,000$ & & & $2,230,000$ \\
\hline \multicolumn{7}{|l|}{ 2-Hexanone } \\
\hline 4-Methyl-2-pentanone & & & $47,000,000$ & & & 528,100 \\
\hline Acetone & & & $54,000,000$ & & & $1,413,000$ \\
\hline Benzene & & & 14,000 & & 1,150 & 643 \\
\hline Bromodichloromethant & & & 18,000 & & & 824 \\
\hline Bromoform & & & $2,200,000$ & & & 61.570 \\
\hline Bromomethane & & & 13,600 & & & 390 \\
\hline Carbon disulfide & & & 720,000 & & & 35,530 \\
\hline Carbon tetrachloride & & & 5,500 & & 2,770 & 217 \\
\hline Chlorobenzene & & & 530,000 & & & 15,070 \\
\hline Chloroethane & & & 65,000 & & & 3,026 \\
\hline Chloroform & & & 4,700 & & 1230 & 221 \\
\hline Chloromethane & & & 160,000 & & & 4,685 \\
\hline Dibromochloromethane & & & 26,000 & & & 1,109 \\
\hline Ethylbenzene & & & 400,000 & & & 186,400 \\
\hline Methylene chloride & & & 210,000 & & 241 & 9,107 \\
\hline Styrene & & & $1,700,000$ & & & 438,210 \\
\hline
\end{tabular}


Table 4. Chemicats and radionuclides required for analysis in

Zone 2 DVS samples and their evaluation eriteriá (continued)

\begin{tabular}{|c|c|c|c|c|c|c|}
\hline $\begin{array}{l}\text { Chemicals and } \\
\text { radionuclides }\end{array}$ & $\begin{array}{c}\text { Maximum } \\
\text { RL }\end{array}$ & $\begin{array}{l}\text { Average } \\
\text { RL }\end{array}$ & $\begin{array}{l}\text { Industrial } \\
\text { PRG }\left(10^{3}\right)\end{array}$ & Backaround & $\begin{array}{c}\text { Groundwater } \\
\text { SL }\end{array}$ & $\begin{array}{l}\text { Residential } \\
\text { PRG }\left(10^{-6}\right)\end{array}$ \\
\hline Tetrachlorothene & & & 13,000 & & 4,720 & 484 \\
\hline Toluene & & & 520,000 & & 502,000 & 65,600 \\
\hline Total Xylente & & & 420,000 & & & 27,000 \\
\hline Trichlorpethene & & & 1,100 & & 1,720 & 53 \\
\hline Vinyl chloride & & & 7,500 & & 176 & 79 \\
\hline cis-1,2-Dichloroethene & & & 150,000 & & & 4,294 \\
\hline cis-1,3-Dichloropropene & & & 18,000 & & & 777 \\
\hline trans-1,2-Dichloroethene & & & 230,000 & & & 6,949 \\
\hline trans-1,3-Dichloropropene & & & 18,000 & & & 777 \\
\hline Diesel Range Organics ${ }^{4}$ & & & & & $100 \mathrm{mg} \mathrm{kg}$ & \\
\hline Gasoline Range Otganics" & & & & & $100 \mathrm{mg} / \mathrm{kg}$ & \\
\hline
\end{tabular}

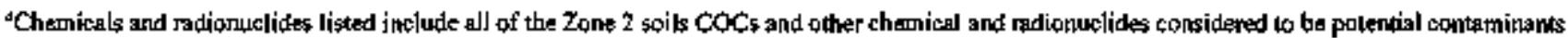
at ETTP. Anabytical laboratories for DV5 samples oten report the results for chemicals and radionuslides nor listed here atod historical das may include analyses for chenicals and rationuclifes not reported in DVS samples. When there is a detection in either a DVS or biscotical sample of a

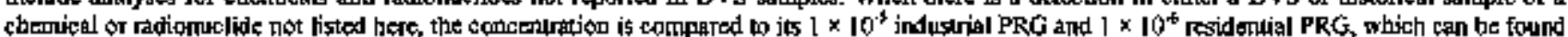
in the Zone 2 RDR/RAWP (DOE 2007a).

Referrad to as soil exposure concentrations in the Zone 2 ROD.

Zone 2 ROD conteminam of concens.

"Radiun-226, Thorium-230, and Tharium-232 are evaluated hy a computalional method that deterenines the primary RAO constituert and whe daughters of the primary sadiomuclide; the total activity of the priasary plus davghers is then compated w escablished Zont 2 RLs that are listed in the Zote 2 RDR/R A WP (DOE 2007a).

"Ditst-range organics and gasoline-range organics apply when there is as UST under invertigation. The J00-mg/kg limit for prolection of groundwater is based on State of Tennessee UST regulations.

$\mathrm{COC}=$ conlasmimanh of concers

DV'S = Dyramic Verification Strategy

ETTP = East Tennesseo Technology Park

PR:G = preliminary remediation gGa]

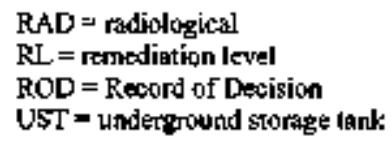

As specified in the Zone $2 \mathrm{ROD}$, all of Zone 2 should be evaluated for unrestricted use with data from the industrial use scenario. In areas where information indicates there is little chance for unacceptable contamination, restrictions will not be imposed (see Sect. 11).

\subsection{DYNAMIC VERIFICATION STRATEGY}

The DVS was developed as required by the Zone 2 ROD and designed to provide sufficient data to fill data gaps, conduct final status assessments for all of Zone 2, and to facilitate real-time decision making. This strategy focused on the soil characterization portion of the Zone 2 ROD to determine where action was needed. Acreage classification was used to progressively focus the investigation efforts in areas with a moderate to high probability of soil contamination (see Sect. 2.1.3). The DVS also helped verify information from previous investigations to incorporate flexibility to facilitate rapid collection of additional data based on data results. The strategy was to gather adequate data with minimal iterations of site investigation planning and mobilization.

The DVS addressed requirements of the Zone 2 ROD RAO with the DQO process. Step 5 of the DVS DQOs presented four decision rules whereby any particular land area in Zone 2 was deemed to have met the RAO requirements (see Table 5). 
Table 5. DVS decision rules for Zone 2 solls

\begin{tabular}{|c|c|c|c|}
\hline $\begin{array}{c}\text { Decision } \\
\text { Rule } \\
\end{array}$ & If & $\begin{array}{l}\text { Then } \\
\end{array}$ & Otherwise \\
\hline 1 & $\begin{array}{l}\text { Concentration of any COC in a } \\
\text { localized area ("hot spot" nominally } \\
50 \text {-ft radius) within an EU to a depth } \\
\text { of } 10 \mathrm{ft} \text { exceeds the maximum RL }\end{array}$ & $\begin{array}{l}\text { Rerrediate Iocalized area of elevated } \\
\text { contamination unti the COC concentration is } \\
\text { less than the maximum RL }\end{array}$ & $\begin{array}{l}\text { NFA for } \\
\text { protection of } \\
\text { industrial worker }\end{array}$ \\
\hline 2 & $\begin{array}{l}\text { Mean concentration value of any soil } \\
\text { COC to a depth of } 10 \text { ft exceeds the } \\
\text { average RL within an EU }\end{array}$ & $\begin{array}{l}\text { Remediate elevated areas of contamination } \\
\text { until the mean COC concentration over the EU } \\
\text { is less than the respective RL }\end{array}$ & $\begin{array}{l}\text { NFA for } \\
\text { protection of } \\
\text { industrial worker }\end{array}$ \\
\hline 3 & $\begin{array}{l}\text { Intustrial risk across the EU to a depth } \\
\text { of } 10 \mathrm{ft} \text { is }>1 \times 10^{-1} \text { ELCR or target } \\
\text { organ HIs exceed } 1\end{array}$ & $\begin{array}{l}\text { Remediate elevated areas of contamination } \\
\text { until residual risk over the EU is below the risk } \\
\text { levels. Evaluate the need for action if target } \\
\text { HIs exceed } 1\end{array}$ & $\begin{array}{l}\text { NFA for } \\
\text { protection of } \\
\text { industrial worker }\end{array}$ \\
\hline 4 & $\begin{array}{l}\text { Site-speciffc contaminants in } \\
\text { groundwater exceed MCL or } \\
\text { site-specific, mass-basted soil SLs" } \\
\text { calculated tor a site for the protection } \\
\text { of groundwaler are exceeded above } \\
\text { the water table or bedrock surface } \\
\text { (whichever is shallower) }\end{array}$ & Evaluate the inpacts of remediating the site & $\begin{array}{l}\text { NFA for be } \\
\text { protection of } \\
\text { groundwrater }\end{array}$ \\
\hline
\end{tabular}

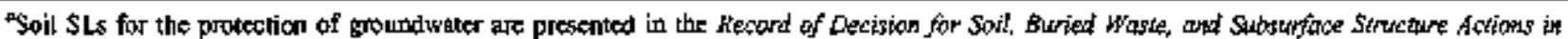

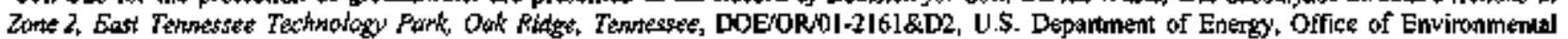
Managemerat, Oak Ridge, TN.

$C O C=$ contaninilzat of concern DVS = Dymamic Verification Stratepy ELCR = excess lifetime canker risk $E \bigcup J=$ exposare unjt HI = hxard index

\author{
MCL = Inaxilmum contaminant [evel \\ NFA = no further action \\ RL - remadiation level \\ SL = sereening level
}

\subsection{FINAL STATUS EVALUATION PROCESS}

The final status recommendation for action/NFA of EU Z2-36 as presented in this PCCR was determined by evaluating the EU in terms of the four decision rules. Descriptions of the action/NFA evaluation processes for each decision rule are presented in Sect. 3.3.1. A discussion of special data uses and considerations in the action/NFA evaluations is included in Sect. 3.3.2. As defined in the Zone 2 ROD, a risk screening was performed to evaluate the industrial land use of each EU. A qualitative risk screening also was conducted against $1 \times 10^{-6}$ residential preliminary remediation goals (PRGs) to evaluate the unrestricted use of each EU. A description of this evaluation is presented in Sect. 3.3.3.

\subsubsection{Action/No Further Action Decision}

The process whereby EUs are evaluated against the four DVS decision rules (see Sect 3.2) is described in the following text and presented graphically in Fig. 5 as Steps 1 through 4.

Decision Rule 1-Maximum RL Evaluation. Zone 2 soils chemical and radjonuclide COC concentrations are screened against their maximum (not to exceed) RLs as defined in the Zone 2 ROD. If any compound is detected at a concentration above its maximum $R L$, an action is required. Maximum RLs and the COCs they are applied to are presented in Table 4. 


\section{STEP ?}

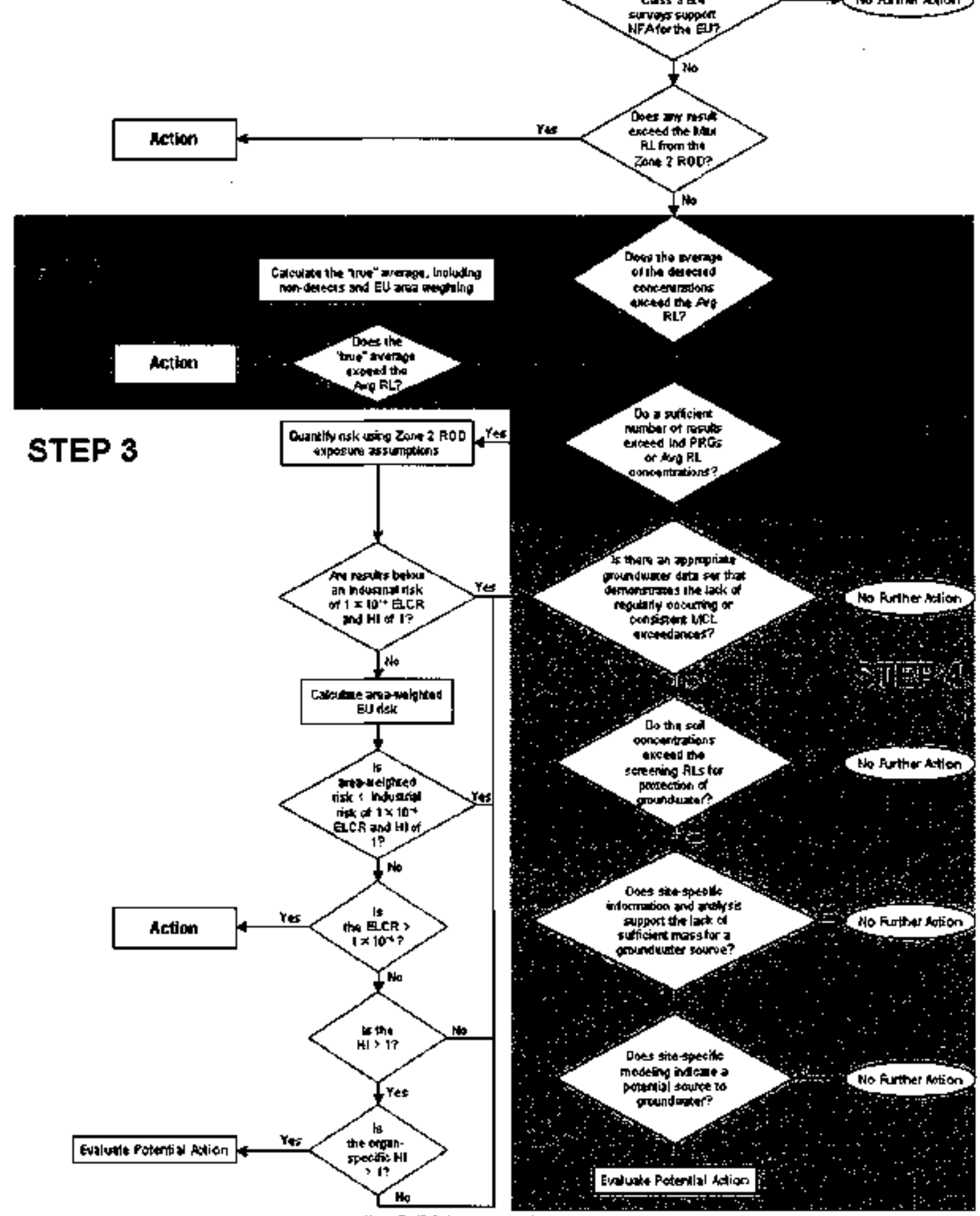

Fig. 5. Risk evaluation process. 
Dexision Rule 2-Average RL Evaluation. The mean value of the detected concentrations for each Zone 2 soil COC across an $\mathrm{EU}$ is screened against the respective average $R L$. If the average detected concentration of any $C O C$ across an $E U$ is less than the average $R L$ for that $C O C$, then the overall average concentration of the COC (which includes non-detected fesults and area weighting) must also be below the average RL.

If the EU average detected concentration of soils COC exceeds the average $R L$ for that COC, then the EU average is calculated using the detected values and half the detection limit for all the non-detect results. If the EU average for this calculation is still in excess of the Zone 2 average RLs, then an area-weighied mean for the EU is calculated (see Sect. 3.3.2). If the area-weighted mean concentration of the $C O C$ is above the Zone 2 average $R L$ for the $C O C$, then an action is required. Average RLs and the COCs they are applied to are presented in Table 4 .

Decision Rule 3 -Cumulative Risk Assessment. The first step in evaluating the cunnulative tisk associated with an EU is to perform a risk screen to determine if further assessment in the form of a tisk calculation is required. The risk screen consists of comparing the data to average RLs and an EPA Region IX ELCR $<1 \times 10^{-5}$ or $\mathrm{HI}$ of 1 . If the concentration of any chemical or radionuclide exceeds either an average RL or an industrial PRG (except as described in Sect. 3.3.2), then the complete EU data set is evaluated to determine if the curnulative effect of all chemicals and radionuclides in the EU would cause the EU to fail the $1 \times 10^{4}$ risk criterion established in the Zone 2 ROD. If suth a determination is made, a risk calculation is conducted as described below. Additional detail on the risk calculation is documented in Stpporting Documentation for Preliminary Remediation Goals Used in the Dynamic Verification Strategy Sampling Program, East Tennessee Technology Park, Oak Ridge, TN (BJC 2006). U.S. Environmental Protection Agency Region DX $1 \times 10^{5}$ industrial PRGs for chemicals and radionuclides analyzed under the DVS are presented in Table 4.

If it is determined by the risk screen that a risk calculation is required, then the risk is calculated in accordance with the Zone 2 ROD by first caleulating the nisk based on the available EU data. If the calculated risk is below an industrial $1 \times 10^{-4}$ ELCR or target organ $\mathrm{HI}$ of 1 , then NFA is appropriate. If not, EU area-weighted calculations are performed.

Because data collection is focused on areas of potential contamination, the resultant data population is more representative of specific portions of an EU than the total EU, and it is the total EU over which risk is to be evaluated according to the Zone 2 ROD. To account for this over emphasis of potentially contaminated areas, an area-weighted risk calculation is performed for the EU. An area-weighted average is calculated for each chemical and radionuclide in the EU according to the area-weighted averaging method described in Sect. 3.3.2, and the cumulative risk is calculated on the area-weighted averages according to the guidelines in the Zone 2 RDR/RAWP (DOE 2007).

If the area-weighted calculation results in an acceptable ELCR $\left(<1 \times 10^{-4}\right)$ and $\mathrm{HI}(<1)$, a NFA determination can be made. However, if the area-weighted calculation results in an unacceptable ELCR $\left(1 \times 10^{-4}\right)$, the EU cannot be cleared for industrial land use and an action determination is made. If the atea-weighted approach results in an unacceptable HI $(>1)$, an individual target organ $\mathrm{HI}$ review is conducted. If individual target organ HIs exceed 1 , an assessment on the need for action is conducted in accordance with the Zone 2 RDR/RAWP (DOE 2007a).

Decision Rule 4-Threat to groundwater. A threat to groundwater by Zone 2 soils is evaluated by reviewing existing area groundwater data for maximum contaminant level (MCL) exceedances that occur on a regular basis. If the groundwater data are sufficient and there are no consistent MCL exceedances, then NFA is appropriate. If the groundwater data are insufficient to discem regular MCL exceedances, or the data are sufficient and regular MCL exceedances are observed, then soil concentrations are screened

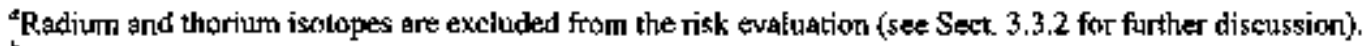

bituber of samples to adequately charactetize the EU and evaluate risk is detemined in the DOO scoping process with the Core Tear Available DVS and historical data are used when risk calculations are performod.
} 
against the SLs for the protection of groundwater as defined in the Zone 2 ROD (DOE 2005). Based on the screening, site-specific modeling may be conducted if additional evaluation is required. Consideration of an action is required if modeling results indicate a site may be a potential source of contamination to groundwater. The sitewide ROD evaluates available site data for threats to groundwater. Data generated from the DVS process will be included in this ROD. Groundwater SLs for chernicals and radionuclides analyzed under the DVS are presented in Table 4.

The Zone 2 ROD specifically addresses USTs at ETTP, including those in Zone 1 and Zone 2. State UST regulations are applicable or relevant and appropriate regulations for all ETTP tanks according to the Zone 2 ROD. Therefore, closure wil] be performed according to State of Tennessee regulations. Tanks that are demonstrated to be clean (i.e., containing no fluids that could adversely effect groundwater) and have no soil contamination present to indicate a leak will be closed in place by filling. Tanks that contain residual fluid and/or where soil contamination indicates a leak witl be removed according to state UST regulations.

\subsubsection{Special Data Uses and Considerations}

Circumstances requiring special data uses and considerations during EU actionNFA evaluations fall into three categories: (1) evaluation of Class 3 and Class 4 SUs that may not have any analytical data, (2) area-weighted averages, and (3) chemicals and radionuclides with regulatory limit concentrations less than or similar in value to background concentrations.

Class 3 and Class 4 SU Evaluations-Some EUs have historical information and the Class 3 and Class 4 SU wakkover assessments provide sufficient information to support the NFA determination. Class 3 and Class 4 SU walkover assessments include visual observations of the SU acreage, collection of radiological survey data, and selected biased sampling where survey results or observations indicate the presence of irmpacted soils.

Area-weighted Averages - Arca-weighted averaging is accomplished by calculating the fraction of the total erea of the EU that contains conteminated soil (cailed a contaminant area fraction). The remaining area of the EU constitutes a remaining acreage area fraction. The average concentration of soil constituents in the area of contamination is calculated and then multiplied by the contaminant area fraction. Average soil concentrations are calculated for the remaining acreage area of the EU using all available sample results or, if no sample data are available, background concentrations. These average concentrations are multiplied by the remaining acreage area fraction. The area-weighted EU average then is calculated as the sum-of-the-fractions.

Regulatory Limit versus Background Concentrations-The industrial PRGs for arsenic, Cs-137, $\mathrm{K}-40$, Ra-226, Th-228, and Th-232 are less than of similat in value to their respective background concentrations, which results in the industrial PRGs exceeding all of most instances where the chemical or radionuclide is detected. It was concluded in the Zone 2 ROD that data for Ra-226, Th-228, and Th-232 will not be used for risk calculations. Instead, health hazards associated with the presence of these radionmelides in Zone 2 soils will be evaluated by comparison to the RLs for Ra-226 and Th-232 (which contzins Th-228 in its decay chain).

When a risk screen is conducted as part of the Decision Rule 3 evaluation (Sect. 3.3.1), secondary concentration comparisons are made in response to PRG exceedances by arsenic, Cs-137, and K-40 before proceeding with the cumulative effects evaluation, which may lead to performing risk calculations for the EU. The industrial PRG for arsenic $(15.9 \mathrm{mg} / \mathrm{kg}$ ) was very close in value to the arsenic backeround concentration $(14.95 \mathrm{mg} / \mathrm{kg})$. Although no local background value exists, the industrial PRG for $\mathrm{Cs}-137$ (1.13 pCi/g) was low enough that this ubiquitous nuclear fallout radionuclide exceeded its PRG in most instances where detected, and the industrial PRG for K-40 (2.73 pCi/g) was less than the background concentration for K-40 (32.12 pCi/g). Secondary concentration comparisons that were 
performed included arsenic concentrations to the arsenic Zone 2 soils average RL, Cs-137 concentrations to the Cs-137 Zone 2 soils average $R L$, and $K-40$ concentrations to the $\mathrm{K}-40$ background value. If any of these secondary concentration comparisons resulted in an exceedance, then the complete EU dataset was evaluated for cumulative effects as described in Sect. 3.3.1.

Ra/Th Decay Series Calculation. Because the carcinogenic risk associated with the concentrations of radium and thorium isotopes in the natural background at ETTP exceed the cumblative risk goal of $1 \times 10^{-4}, \mathrm{RL}$ values for these radionuclides were based on alternative concentration levels rather than risk. The altemative concentration levels of $5 \mathrm{pCi} / \mathrm{g}$ above background (average RL) and $15 \mathrm{pCi} / \mathrm{g}$ above background (maximum $\mathrm{RL}$ ) were set as low as ressonably achievable under the site-specific conditions. Concentrations of these radionuclides and their decay series were not considered in the risk estimates because site-specific background concentrations of the radionuclides exceeded the target risk range.

The Zone 2 ROD states that average RL and maximum RL exceedances by Ra-226, Th-230, and Th-232 are to be evaluated by summing above-background concentrations of the greater of Ra-226 or Th-230 with the above-background concentrations of Th-232, and comparing the results to $5 \mathrm{pCi} / \mathrm{g}$ (average RL) and $15 \mathrm{pCi} / \mathrm{g}$ (maximum RL). These calculations were perfomed by subtracting the background values of Ra-226, Th-230, and Th-232 from the analytical result. $A$ Ra/Th decay series value then was calculated for each sample by selecting the larger of the Ra-226 or Th-230 value and summing the selected value with the Th-232 value.

The $R a$ Th decay series was considered to be analyzed in a sample if one or more of the three radionuclides it comprised were analyzed for in the sample. Also, this decay series was considered to be detected in a sample if one or more of the three radionuclides it comprised were detected in a sample. It is possible that a Ra/Th decay series detected value could equal zero.

\subsubsection{Qualitative Risk Screening for Unrestricted Use.}

While not required by the Zone 2 ROD, a qualitative risk screening for unrestricted use was conducted to determine the possibility of releasing the EUs without institutional controls. These results are provided for information only and do not form the basis for action (see Sect. 11). For this screening, average concentrations were compared to $1 \times 10^{-6}$ residential PRGs and ETTP soils background values from Table 4 in Soll Backgrotund Supplemental Data Set for the East Tennessee Techrology Park, Oak Ridge, Tennessee (DOE 2003). EPA Region IX residential PRGs $1 \times 10^{-6}$ and ETTP soil background values for the chemicals and radionuclides analyzed for under the DVS are presented in Table 4. 


\section{FINAL STATUS ASSESSMENTS}

This section presents the DVS evaluation results for EU Z2-36 and the final status assessment based on that evaluation. Guidelines for the evaluation are presented in Sect 2 and for preparing the final status assessment are presented in Sect. 3. A high-level summary of the DVS evaluation is presented in Table 6.

The final status assessment conclusions for EU Z2-36 are presented in Table 7, which is followed by a summary of the evaluation and conchusions. The conclusions and summaries presented in Table 8 were based on the evaluation of existing information in terms of the four DVS decision rules described in Sect. 3. Table 7 provides the information by EU and includes the EU acreage, Class 1 and Class 2 SU acreage, Class 3 SU acreage, and FFA sites in each EU.

Because all samples within the 0 - to 10 -ft soil interval were considered equally in the risk assessment, there was no differentiation of the contamination information by depth. Any contamination in the 0-to 10 -ft interval was considered to be equally accessible to an industrial worker. Depth information for discrete interval samples, including all VOC samples and the majority of the radiological samples, is provided in the accompanying compact disc (CD). Because there is no depth differentiation of the potential impact of contamination, details regarding sample intervals were not included in the EU evaluation presented in the following text.

Details of the material presented in Tables 6 and 7 and the associated summaries are presented in the EU Z2-36 TM (see Appendix A). Analytical data summary tables are also presented in the TM. The complete set of analytical data used to generate the summary data tables is provided in the CD attached to this PCCR. Data are also available in the OREIS database, which can be accessed by contacting DOE.

Recommendations for the Zone 2 ROD Appendix A FFA sites are summarized it Table 8. Characterization, evaluation, and remediation of these sites will be used as a metric for the closure of ETTP. If the evaluation of all available data for an EU supported a NFA detemination at the EU level, then all FFA sites within that EU were considered NFA by inclusion. If a limited set of data resulted in an action being required within an EU, then the final status of the EU and all included FFA sites was deferred until the action was complete and an EU-level NFA determination was made.

Table 6. DVS evaluation sumniary for EU Z2-36

\begin{tabular}{ll}
\hline Bulk gcreage summary & \\
\hline Total acreage in Zone 2 & 819 \\
Acreage included in this PCCR & 15 \\
Acreage for NFA - no RA & 15 \\
Acreage for NFA - post RA & 0 \\
Acreage of RAs conducted & $<1$ \\
Acreage of RAs to be conducted & 0 \\
\hline SU tlassicifation snmmary for ncreage in the PCCR & \\
\hline Class 1 SU acreage & 0 \\
Class 2 SU acreage & 2 \\
Class 3 SU acreage & 13 \\
Class 4 SU acreage & 0 \\
\hline
\end{tabular}


Table 6. DVS evaluntion snnmary for EU Z2-36 (continued)

\begin{tabular}{|c|c|c|}
\hline \multicolumn{3}{|l|}{ EU 8mmuary } \\
\hline $\begin{array}{l}\text { Number of EUs in Zone } 2 \\
\text { Number of EUs addressed in this PCCR } \\
\text { Number of EUs for NFA } \\
\text { Number of EUs for NFA - post RA }\end{array}$ & \multicolumn{2}{|l|}{$\begin{array}{l}44 \\
1 \\
1 \\
0\end{array}$} \\
\hline \multicolumn{3}{|l|}{ Characterization sumbary } \\
\hline Sarnple analyses DVS and historical & $\begin{array}{l}\text { Metal: } 32 \\
\text { PCB: } 27 \\
\text { Radionuclide: } 24 \\
\text { SVOC: } 27\end{array}$ & $\begin{array}{l}\text { VOC: I8 } \\
\text { Other: } 8 \\
\text { TCLP SVOC: } 0 \\
\text { TCLP Metals: } 0\end{array}$ \\
\hline $\begin{array}{l}\text { Radiological walkover survey acreage } \\
\text { Geophysical survey acreage } \\
\text { Linear feet of soil core obtained }\end{array}$ & $\begin{array}{l}0 \\
0 \\
\text { Approximately } 12\end{array}$ & \\
\hline Class 3 and Class 4 SU walkover assessments & \multicolumn{2}{|c|}{$\begin{array}{l}\text { Assessment point locations: } 16 \\
\text { Mid-point locations: } 15 \\
\text { Discretionary point locations: } 15 \\
\text { Total locations assessed: } 46\end{array}$} \\
\hline
\end{tabular}

K-1098-C Asphalt Plant

K-1503 Neutralization Pit

\section{FPA Sites - Additional Action}

None

"The need for RA anywhere is an EU indicated the NFA dexision could not be fiode for the whole EU until the artion thas complete. Final statug of FFA sites within me EU where an action was plapned was contingen on completion of the RA. "Acrtage for NFA-post RA" indicates the sum of acreages in which a RA was to be conducted. "Acreages of RAs to be conducted" indicates the sum of acreages of the aclions thentselyes.

DVS = Dynamic Verification Strategy EU $=$ exposure unit

$F F A=$ Federal Facility Agreement

NFA $\Rightarrow$ in further action

$\mathrm{PCB}=$ polychloriagted biphenyl

PCCR = Phased Construction Completion Report
RA = remedial actín

SU $=$ soil unit

SWOC - setrivolatile organic compound

TCLP = toxicity charateteristic leaching procodure

VOC = volatile arganic compound 
Table 7. Final status assessnent sumunary for EU Z2-36

\begin{tabular}{|c|c|c|c|c|c|c|c|}
\hline $\begin{array}{l}\text { EU size } \\
\text { (atres) }\end{array}$ & EU Group & $\begin{array}{c}\text { Zone } 2 \text { ROD } \\
\text { Appendix A FFA sites }\end{array}$ & $\begin{array}{l}\text { Class } 1 \text { and } 2 \\
\text { SU area } \\
\text { (acres) }\end{array}$ & $\begin{array}{c}\text { Class } 3 \text { and } 4 \\
\text { SU area } \\
\text { (acres) }\end{array}$ & Rlsk evaluation & $\begin{array}{c}\text { Decision rule } \\
\text { evaluation }\end{array}$ & $\begin{array}{c}\text { Final status } \\
\text { dectșion }\end{array}$ \\
\hline \multirow[t]{2}{*}{15} & Main Plant & K-1098-C Asphal1 Plant & -- & - & Passes tisk screen & $\begin{array}{l}\text { Max RL: NPA } \\
\text { Avg RL: NFA } \\
\text { Risk: NFA } \\
\text { GW: NFA }\end{array}$ & NFA for soils \\
\hline & & K-1503 Neulralization P'it & & & Passes tisk scieen & $\begin{array}{l}\text { Max RL: NFA } \\
\text { Avg RL: NFA } \\
\text { Risk: NFA } \\
\text { GW: NFA }\end{array}$ & NFA for soils \\
\hline
\end{tabular}

\section{Avg $=$ syerage}

EU $=$ exposure unil

$G W=$ groundwater

Max $=$ maximun
NFA = no further action

RL a remediation kewel

ROD = Recond of Dexision

SU $=$ soil unit 
Table 8. Summary of conclusions for EU Z2-36 Zone 2 ROD Appendix A FFA sites

\begin{tabular}{lc}
\hline \multicolumn{1}{c}{ Zone 2 ROD Appendix A FFA Site } & Recommendation \\
\hline K-1098-C Asphalt Plast & NFA \\
K-1503 Neutrabization Plant & NFA
\end{tabular}

$\begin{array}{ll}\text { EUI = exposure trnit } & \text { NFA }=\text { no furtlier action } \\ \text { FEA = Federal Frcility Agreengent } & \text { ROD }=\text { Recoud of Desision }\end{array}$

\subsection{EXPOSURE UNIT EVALUATION}

The following section summarizes the evaluation and conclusions for EU Z2-36. Details of the material presented in Tables 6, 7, and 8, and the following section, are presented in Appendix A. The evaluation is performed and presented from a post-RA perspective by removing from the analysis data from all locations where RA was performed.

\subsubsection{Erposure Unit Z2-36}

EU Z2-36 is located in the east central portion of Zone 2 in the Main Plant EU Group (Fig. 1), and is bounded on the north by EU Z2-35 and EU Z2-39, on the east by EU Z2-40 and Zone 1, on the south by EU Z2-41, and on the west by EU Z2-31. All of the land area in this EU has been impacted by site operations. Impacts to the EU included construction of buildings, roads, parking lots, and sidewalks.

Exposure unit Z2-36 has two FFA sites that are listed in Appendix A of the Zone 2 ROD (Fig. 2):

- K-1098-C Asphalt Plant,

- K-1503 Neutralization Pit, and

One conceptual model applies to EU Z2-36. The conceptual site model is a surface release model related to fuel storage facilities in the EU. There was a known spill from the K-150l Diesel Storage Tank in the 2000 .

EU Z2-36 contains only Class 2 and Class 3 SUs. The Class 2 SUs include K-1501-A/B and K-1501-J which comptise an area of approximately 2 acres. Sampling but no radiological surveys were performed in these SUs.

The remainder of EU Z2-36 is a Class 3 SU where walkover assessments and bjased sampling was performed.

The following is a summary of the data evaluation for EU Z2-36.

\begin{tabular}{cccccc}
\hline EU \# & $\begin{array}{c}\text { Max RL } \\
\text { exceded? }\end{array}$ & $\begin{array}{c}\text { Average RL over } \\
\text { EU exceeded? }\end{array}$ & $\begin{array}{c}\text { Industrial risk } \\
\text { above } 1 \times 10^{-4} \text { ? }\end{array}$ & $\begin{array}{c}\text { Potential saurce } \\
\text { to gronndwater? }\end{array}$ & $\begin{array}{c}\text { Action } \\
\text { requidred? }\end{array}$ \\
\hline$Z 2-36$ & No & No & $N_{0}$ & $N_{0}$ & No \\
\hline
\end{tabular}

- There are no Max RL exceedances in EU Z2-36.

- No average COC concentration across EU Z2-36 exceeded its Avg RL.

- The industrial risk for EU Z2-36 was calculated to be $<1 \times 10^{-4}$ ELCR, with a target organ HI of 1 . 
- Despite the presence of VOC groundwater contaminant plumes beneath EU Z2-36, the source areas are located to the south in EU Z2-41. The EU Z2-36 soils do not contribute to those plumes and do not pose a threat to groundwater.

- No further action is necessary to mett industrial land use.

There is a low probability that the acreage of EU Z2-36 could be released with no land use restrictions. There is one location with two PCB Avg RL exceedances that will remain because the exceedances do not cause the average concentrations across the EU to exceed the Avg RL and there are widespread Ind PrG excedances and residential PRG exceedances. There have also been a substantial number of historical VOC MCL exceedances across the EU associated with known groundwater contaminant plumes beneath the EU, 


\section{REMEDIATION ACTIVITIES}

The remedial action of backfilling the building K-1501 basement and two small adjacent pits, normally described in this section, was described in Fiscal Year 2007 Phased Construction Completion Report for the Zone 2 Soils, Slabs, and Subsurface Structures at East Tennessee Technology Park, Oak Ridge, Tennessee (DOE 2007b). There were no other completed RAs in EU Z2-36 to be addressed in this PCCR.

\subsection{END STATE}

The building 1501 basement was planted in domestic grass that will require mowing, and the two small adjacent pits were covered with gravel. 


\section{DEVIATIONS FROM GOVERNING DOCUMENTS}

Zone 2 was divided into 7 geographic areas and 44 EUs in the ROD (DOE 2005). To facilitate the DQOs, the Zone 2 RDR/RAWP (DOE 2007a) regrouped the 44 EUs into 12 DQO scoping EU groups, which facilitated the DQO process by placing similar facilities and their support facilities together and allowing identification of data gaps.

It is not uncomnon for EU acreages reported in PCCRs to differ from that reported in the ROD because of boundary refinement and an increased level of accuracy. In the case of EU Z2-36, however, the 15 acres used in this PCCR is the same as that teported in the ROD.

The RA Core Team concurrence process is an integral part of DVS implementation, which allows actions such as revising sampling locations or RA implementation based on field conditions encountered. Table 9 lists the FCNs and concurrences submitted to and reached by the RA Core Tean pertaining to the DVS characterization and RAs assessed in this PCCR.

Table 9. EU Z2-36 FCNs and concurrences

\begin{tabular}{|c|c|c|c|c|}
\hline $\begin{array}{l}\text { Log } \\
\text { number }\end{array}$ & FCN number & Title or description & $\begin{array}{c}\text { Date } \\
\text { Issued }\end{array}$ & $\begin{array}{c}\text { Date } \\
\text { approved }\end{array}$ \\
\hline \multirow[t]{9}{*}{94} & & $\begin{array}{l}\text { Main Plant Group changes to DQO base } \\
\text { program }\end{array}$ & $3 / 1 / 2006$ & $3 / 15 / 2006$ \\
\hline & FCN-ETTP-Zone 2-026 & $\begin{array}{l}\text { Main Plan EU Group DQO Scoping Package } \\
\text { Backfilling the K-1501 basement (Z2-EU36) }\end{array}$ & $12 / 20 / 2006$ & $1 / 5 / 2007$ \\
\hline & FCN-ETTP-Zone 2-035 & $\begin{array}{l}\text { Main Plant EU Group DOO Scoping Package } \\
\text { biased sampling in K-1501 sump (Z2-EU36) }\end{array}$ & $3 / 7 / 2007$ & $3 / 20 / 2007$ \\
\hline & FCN-ETTP-Zone 2-037 & $\begin{array}{l}\text { Main Plant EU Group DQO Scoping Package } \\
\text { backfill K-1501 basement in EU } 36\end{array}$ & $3 / 12 / 2007$ & $3 / 22 / 2007$ \\
\hline & FCN-ETTP-Zone 2-038 & $\begin{array}{l}\text { Main Plant EU Group DQO Scoping Package } \\
\text { biased sampling in K-1501 pit (Z2-EU36) }\end{array}$ & $3 / 29 / 2007$ & $4 / 12 / 2007$ \\
\hline & FCN-ETTP-Zone 2-043 & $\begin{array}{l}\text { Main Plant EU Group DQO Scoping Packsge } \\
\text { backfill the K-1501 pit (Z2-EU36) }\end{array}$ & $5 / 15 / 2007$ & $5 / 24 / 2007$ \\
\hline & FCN-ETTP-Zone 2-088 & Move Main Plant sample locations (EU Z2-36) & $7 / 9 / 2008$ & $7 / 17 / 2008$ \\
\hline & FCN-ETTP-Zone 2-093 & Delete samples in EUs 12, 32, and 36 & $\begin{array}{l}8 / 21 / 2008 \\
\text { resubrnitted } \\
9 / 29 / 2008\end{array}$ & $10 / 14 / 2008$ \\
\hline & FCN-ETTP-Zone 2-098 & $\begin{array}{l}\text { Revise DQO sampling at K-1501-J Class } 2 \mathrm{SU} \\
\text { (EU-Z2-36) }\end{array}$ & $10 / 7 / 2008$ & $10 / 9 / 2008$ \\
\hline
\end{tabular}




\section{COSTS AND SCHEDULE FOR REMEDIAL ACTION(S)}

Aside from the remedial action of backfilling the Bldg. K-1501 basement and two small adjacent pits described in Sect 5, there were no other completed RAs in EU Z2-36 addressed in this POCR. 


\section{WASTE MANAGEMENT ACTIVITIES FOR REMEDIAL ACTION(S)}

Aside from the remedial action of backfilling the Bldg. K-1501 basement and two small adjacent pits described in Sect. 5, there were no other completed RAs in EU Z2-36 addressed in this PCCR. 


\section{OPERATIONS AND MAINTENANCE}

Aside from mowing, no operations and maintenance is required for the Bldg. 1501 basement and adjacent pits backfill RA performed. 


\section{MONITORING SCHEDULE AND/OR EXPECTATIONS}

There are no monitoring requirements for the RA performed in EU Z2-36. 


\section{LAND USE CONTROLS}

This section discusses general land use controls for the EUs in Zone 2 at ETTP. Details of the controls will be presented in the Remedial Action Report. An assessment for possible unrestricted use of EU Z2-36 is presented in Sect. 11.4.

Dynamic Verification Strategy characterization of EU Z2-36 was conducted in accordance with the requirements of the Zone 2 ROD and RDR/RAWP. The goal of characterization was to gather sufficient information to evaluate the EU against the four decision rules developed in the DVS DQOs (Table 5) and arive at an action/NFA decision. The decision rule evaluation process used in this PCCR is described in Sect. 3. Consistent with the Zone 2 ROD, a NFA decision means an EU is available for unrestricted industrial use to a depth of $10 \mathrm{ft}$ bgs.

\subsection{POSSIBLE LIFTING OF LAND USE CONTROLS}

As required by the Zone 2 ROD, this section presents an evaluation of EU Z2-36 for the possible lifting of the following two land use controls:

- Industrial land use controls below $10 \mathrm{ft}$ bgs, and

- Making the EU available for unrestricted land use.

The DVS process and EU status assessment presented in this PCCR for EU Z2-36 can assign a high, medium, or low qualitative probability of lifting land use controls.

\subsection{DEFINITIONS}

High probability - This designation indicates no identified areas of contaminated soils and there are no significant disposal or landfill operations observed in the EU. Dynamic Verification Strategy evaluations indicate no identified impact within the EU and a high probability the acreage could be released with no land use controls following appropriate evaluation.

Medium probability - This designation indicates an identifiable impact from facility operations to some portion of acreage in the EU. This inpact may be visible nubbish and debris, concentrations of several metals and/or radionuclides above background levels, and/or the detection of organic compounds in a few samples within the EU. Based on the observations and sample results, the impact appears to be minor and limited in extent. There is a moderate probability the acreage could be released following appropriate evaluation.

Low Probability-This designation indicates a clearly identified impact to substantial portions of acreage within the EU. Metals and radionuclides are commonly above background levels and organic compounds may be present in several samples within the EU at levels above I $\times 10^{-6}$ residential PRGs. The probability of uniestricted use of the acreage is low.

\subsection{INDUSTRIAL CONTROLS AT DEPTH}

An evaluation was performed to determine if EU Z2-36 would require industrial controls below $10 \mathrm{ft}$ bgs. The DVS program was designed to assure the top $10 \mathrm{ft}$ of soil meet industrial criteria. However, sufficient information exists to make reasonable conclusions regarding the need for land use controls below $10 \mathrm{ft}$ of soil. A VOC groundwater plume is known to exist in the central portion of EU Z2-36 at a 
depth of $+/-25 \mathrm{ft}$ below ground surface. Therefore, it is proposed to retain land use restrictions below 10 ft for EU Z2-36.

\subsection{POTENTIAL UNRESTRICTED USE}

To conduct the evaluation and detemine the probability of lifting land use controls, EU Z2-36 analytical data were compared to background concentrations and $1 \times 10^{-6}$ residential PRGs. A qualitative assessment of the comparison results applicability to the whole EU was made. DVS sampling is biased to areas with relatively high probabilities of contamination being present (i.e., DVS systematic sampling is focused on Class I and Class 2 SUs and DVS biased sampling is conducted in all SUs based on a determination from visual and screening assessments that there is a likelibood of contamination). As a result, the presence of background or $\mathbf{l} \times 10^{-6}$ residential-use PRG concentration exceedances in the data set does not automatically preclude the possibility of lifting industrial land use controls. The probability of lifting land use controls for acreage in Zone 2 is generally low because it has been extensively impacted by the construction of ETTP facilities, infrastructure, and heavy industrial activities. Sample results consistently indicate impact to area soils above background levels and commonly above industrial use PRGs. Also, unrestricted use of Zone 2 acreage is an unlikely alternative because there are many small structures and abandoned infrastructures in the area.

Further evaluation is recommended before a final conclusion can be made concerning lifting industrial land use controls because the DVS process was designed around requirements of the Zone 2 ROD, which specifies an unrestricted industrial land use.

To evaluate for urrestricted use, appropriate DQOs were developed that considered but were not limited to the following:

- Calculated RLs consistent with the risk management requirements of an unrestricted land use scenario,

- Remediation levels for chemicals and radjonuclides where background concentrations are greater than residential PRGs (i.e., aluminum, assenic, iron, manganese, K-40, Ra-226, Th-228, and Th-232),

- Remediation levels for Cs-137, a ubiquitous fallout radionuclide that does not have a determined background concentration but typically exceeds its residential PRG when detected, and

- EU size.

Taking the above information into account, results of the evaluation process determined there is a low probability that land use controls can be lifted at EU Z2-36. There is one location with two PCB Avg RL exceedances that will remain because the exceedances do not cause the average concentrations across the EU to exceed the Avg RI and there are widespread Ind PIG exceedances and residential PRG exceedances.

\subsection{REMAINING ACTIVITIES}

This section summarizes activities remaining to be completed in Zone 2 . The rationale for these activities falls into the following four categories:

- Remaining activity is an action to be performed,

- Remaining activity awajts a risk management decision,

- Rernaining activity is part of a larger infrastructure investigation to be conducted at a later date, or

- Remaining activity awaits D\&D to make soils accessible. 
The status of each EU in Zone 2 is presented in Table 12. The status of Zone 2 RA characterization as of this PCCR is shown in Fig. 13. As shown in Fig. 13, characterization bas been completed in 18 of 44 Zone 2 EUs ( 328 of 800 acres).

Table 10. Status of Zone $2 \mathrm{EUs}$

\begin{tabular}{|c|c|c|c|c|c|c|}
\hline EU & $\begin{array}{c}\text { Characterization } \\
\text { complete? }\end{array}$ & $\begin{array}{l}\text { NFA on soil } \\
\text { apprapriate? }\end{array}$ & $\begin{array}{c}\text { NFA on } \\
\text { infrastructure } \\
\text { appropriate? }\end{array}$ & $\begin{array}{l}\text { Action } \\
\text { required? }\end{array}$ & $\begin{array}{c}\text { Closure } \\
\text { documentation? }\end{array}$ & $\begin{array}{l}\text { Comment } \\
\text { explanation }\end{array}$ \\
\hline$Z 2-01$ & $\checkmark$ & $r$ & $\checkmark$ & & FY $2007 \mathrm{PCCR}$ & \\
\hline $\mathrm{Z} 2-02$ & $\checkmark$ & $\checkmark$ & $\checkmark$ & & FY 2006 PCCR & \\
\hline $\mathrm{Z} 2-03$ & $\checkmark$ & $\checkmark$ & $\checkmark$ & & FY 2007 PCCR & \\
\hline $22-04$ & & & & & PCCR or Zone 2 RAR & \\
\hline $22-05$ & & & & & PCCR or Zone 2 RAR & \\
\hline$Z 2-06$ & & & & & POCR or Zone 2 RAR & \\
\hline $\mathrm{Z} 2-07$ & $\checkmark$ & $\checkmark$ & $\checkmark$ & & FY 2006 PCCR & \\
\hline $\mathrm{Z} 2-08$ & $\checkmark$ & $\checkmark$ & $\checkmark$ & & FY 2007 PCCR & \\
\hline $\mathrm{Z} 2-09$ & $\checkmark$ & $\checkmark$ & $\checkmark$ & & FY 2006 PCCR & \\
\hline $22-10$ & $\checkmark$ & $\checkmark$ & $\checkmark$ & & FY 2006 PCCR & \\
\hline$Z 2-11$ & & & & & POCR or Zone 2 RAR & \\
\hline $\mathrm{z} 2-12$ & & & & & PCCR or Zone 2 RAR & \\
\hline$Z 2-13$ & & & & & PCCR or Zone 2 RAR & \\
\hline Z2-14 & & & & & PCCR or Zone 2 RAR & \\
\hline Z2-15 & & & & & PCCR or Zone 2 RAR & \\
\hline $\mathrm{Z} 2-16$ & & & & & PCCR or Zone 2 RAR & \\
\hline $\mathrm{Z} 2-17$ & & & & & PCCR or Zone 2 RAR & \\
\hline Z2-18 & & & & & PCCR or Zone 2 RAR & \\
\hline 22-19 & & & & & PCCR or Zone 2 RAR & \\
\hline $\mathrm{Z} 2-20$ & & & & & PCCR or Zone 2 RAR & \\
\hline $\mathrm{Z} 2-21$ & & & & & PCCR or Zone 2 RAR & \\
\hline $\mathrm{Z} 2-22$ & & & & & PCCR or Zone 2 RAR & \\
\hline $\mathrm{Z} 2-23$ & $\checkmark$ & $\checkmark$ & $\checkmark$ & & FV $2007 \mathrm{PCCR}$ & \\
\hline$Z 2-24$ & $\checkmark$ & $\checkmark$ & $\checkmark$ & & FY 2007 PCCR & \\
\hline $\mathrm{Z} 2.25$ & & & & & PCCR or Zone 2 RAR & \\
\hline $\mathrm{Z} 2-26$ & & & & & PCCR or Zone 2 RAR & \\
\hline
\end{tabular}


Table 10. Status of Zone 2 EUs (continued)

\begin{tabular}{|c|c|c|c|c|c|c|}
\hline EU & $\begin{array}{c}\text { Characterization } \\
\text { complete? }\end{array}$ & $\begin{array}{l}\text { NFA on soil } \\
\text { appropriate? }\end{array}$ & $\begin{array}{c}\text { NFA on } \\
\text { infrastructure } \\
\text { appropriate? }\end{array}$ & $\begin{array}{c}\text { Action } \\
\text { required? }\end{array}$ & $\begin{array}{c}\text { Closure } \\
\text { documentation? }\end{array}$ & $\begin{array}{c}\text { Comment } \\
\text { Erplantion }\end{array}$ \\
\hline$\overline{Z 2-27}$ & $\checkmark$ & $\checkmark$ & $\checkmark$ & & FY 2006 PCCR & \\
\hline $22-28$ & $\checkmark$ & $\checkmark$ & $\checkmark$ & $\checkmark$ & FY 2007 PCCR & \\
\hline 22.29 & & & & & PCCR or Zone 2 RAR & \\
\hline $22-30$ & & & & & PCCR or Zone 2 RAR & \\
\hline $22-31$ & & & & & PCCR or Zone 2 RAR & \\
\hline $\mathrm{Z2}-32$ & & & & & PCCR or Zone 2 RAR & \\
\hline $22-33$ & $\checkmark$ & $\checkmark$ & $\checkmark$ & $\checkmark$ & $\begin{array}{l}\text { FY } 2008 \text { EU Z2-33 } \\
\text { PCCR }\end{array}$ & $\begin{array}{l}\text { Bldg. K-1006 } \\
\text { north sump } \\
\text { recommended } \\
\text { RA will be } \\
\text { performed } \\
\text { when the } \\
\text { facility is } \\
\text { dernolished; } \\
\text { recommended } \\
\text { action added } \\
\text { to FFA } \\
\text { Appendix J }\end{array}$ \\
\hline Z2-34 & $\checkmark$ & $\checkmark$ & $\checkmark$ & & FY 2007 PCCR & \\
\hline $\mathrm{Z} 2-35$ & & & & & PCCR of Zone 2 RAR & \\
\hline $\mathrm{Z} 2-36$ & $\checkmark$ & $\checkmark$ & $\checkmark$ & & $\begin{array}{l}\text { FY 20095 EU } 22-36 \\
\text { PCCR }\end{array}$ & \\
\hline $22-37$ & $\checkmark$ & $\checkmark$ & $\checkmark$ & & FY $2007 \mathrm{PCCR}$ & \\
\hline Z2-38 & & & & & PCCR or Zone 2 RAR & \\
\hline $22-39$ & & & & & PCCR or Zone 2 RAR & \\
\hline $22-40$ & & & & & PCCR of Zone 2 RAR & \\
\hline $22-41$ & $\checkmark$ & $\checkmark$ & $\checkmark$ & $\checkmark$ & FY 2007 PCCR & \\
\hline $\mathrm{Z2}-42$ & $\checkmark$ & $\checkmark$ & $\checkmark$ & $\checkmark$ & PCCR or Zone 2 RAR & $\begin{array}{l}\text { Soil RA } \\
\text { complete; } \\
\text { K-I004-J } \\
\text { Vaults FFA } \\
\text { Site requires } \\
\text { RA }\end{array}$ \\
\hline $22-43$ & $\checkmark$ & $\checkmark$ & $\checkmark$ & & FY 2007 PCCR & \\
\hline $22-44$ & $r$ & $r$ & $\checkmark$ & & FY 2007 PCCR & \\
\hline
\end{tabular}

The check matk in this column indicates either the infrastructure has been evaluated or there is no inftastructure requiring evaluation.

$\mathrm{EU}=$ Exprosure usit

FFA - Federal Faciliry Agretement

FY $=$ fiscoll yestr

NFA = no further action
PCCR = Phased Construction Commitetion Report

RA = remedial actior

RAR = Returedial Action Report 


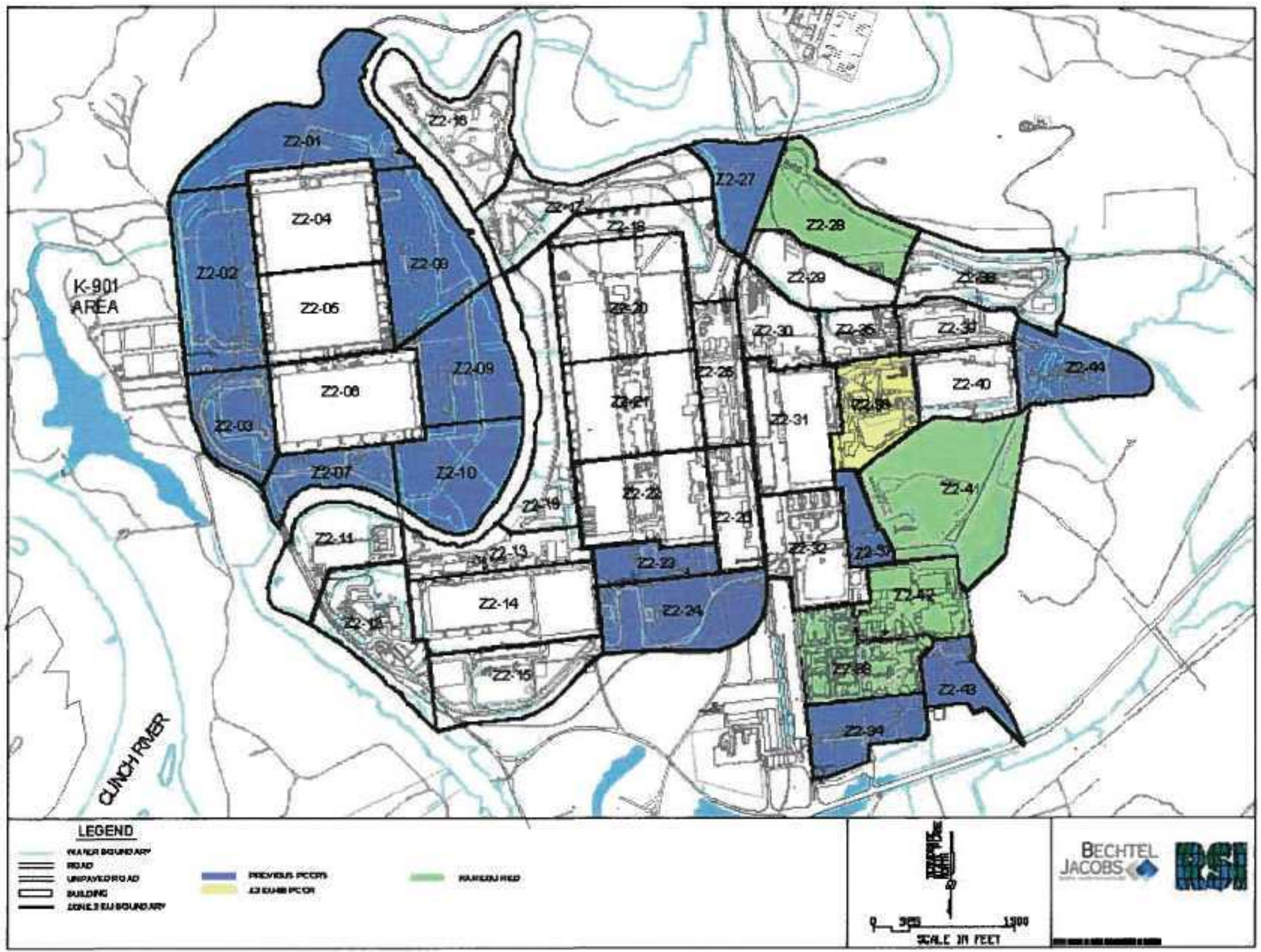

Fig. 6. EUs Included in EU Z2-36 PCCR. 


\section{REFERENCES}

BJC 2006. Stpporting Documentation for Preliminary Remediation Goals Vsed in the Dynamic Verification Strategy Sampling Program, East Tennessee Technology Park, Oak Ridge, TN, BJC/OR-2383, Bechtel Jacobs Company LLC, Oak Ridge, TN.

BJC 2007. Zone 2 Dynamic Work Plan, East Tennessee Technology Park, Oak Ridge, Tennessee, BJC/OR-2373/R1.

DOE 1992. Federal Facility Agreement for the Oak Ridge Reservation, DOE'OR-1014, EPA.Region 4, DOE, and TDEC, Washington, D.C.

DOE 1993a. Final Report on the Background Soil Characterization Project at the Oak Ridge Reservation, Oak Ridge, Tennessee, Volume 1 - Results of Field Sampling Program, DOE/OR/01-1175N1, October.

DOE 1993b. Radtation Protection of the Public and the Environment, DOE 0 5400.5, Change 2, U.S. Department of Energy, Washington, D.C.

DOE 2003. Soil Backgrotund Supplemental Data Set for the East Tennessee Technology Park, Oak Ridge. Tennessee, DOE/OR/01-2105\&D1, U.S. Department of Energy, Office of Environmental Management, Oak Ridge, TN.

DOE 2005. Record of Dectision for Soil, Buried Waste, and Subsurface Structure Actions in Zone 2, East Tennessee Technology Park, Dak Ridge, Tennessee, DOE/OR/01-2161\&D2, U.S. Department of Energy, Office of Environmental Management, Oak Ridge, TN.

DOE 2006. Fiscal Year 2006 Phased Construction Completion Report for the Zone 2 Soits, Slabs, and Subsurface Structures at East Tennessee Technology Park, Oak Ridge, Tennessee, DOE/OR/01-2317\&D2, U.S. Department of Energy, Office of Environmental Management, Oak Ridge, TN.

DOE 2007a. Remedial Design Report/Remedial Action Wort Plan for Zone 2 Soils, Slabs, and Subsufface Stnuctures, East Tennessee Technology Park, Oak Ridge, Tennessee, DOE/OR/01-2224\&D3, U.S. Department of Energy, Office of Environmental Management, Oak Ridge, TN.

DOE 2007b. Fiscal Year 2007 Phased Construction Completion Report for the Zone 2 Soits, Slabs, and Subsurface Structures at East Tennessee Technology Park, Oak Ridge, Tennessee, DOE/OR/01-2723\&D1, U.S. Department of Energy, Office of Environmental Management, Oak Ridge, TN, September.

EPA 1989. Risk Assessment for Superfund, Vol. I Human Health Evaluation Manual (Part A), EPA/540/1 -89/002, U.S. Environmental Protection Agency, Washington, D.C.

EPA 2002. Guidance for Comparing Background and Chemical Concentrations in Soil for CERCLA Sites, EPA-540-R-01-003, EPA Region IV, Washington, D.C.

MMES 1994. Cable Insulation PCB Analysis, Intemal Correspondence, Martin Marietta Energy Systems, Inc., February 28, 1994. 
ORISE 2000. Polychlorinated Biphenyl and Asbestos Sampling and Analysis Report for the $K-762$ and K-792 Switchyard Site, East Tennessee Technology Park, Oak Ridge, Tennessee (Draft), Oak Ridge Institute for Science and Education, December 14, 2000. 
Appendix A

Main Plant Exposure Unit Group Zone 2 EU 36

Technical Memorandum 


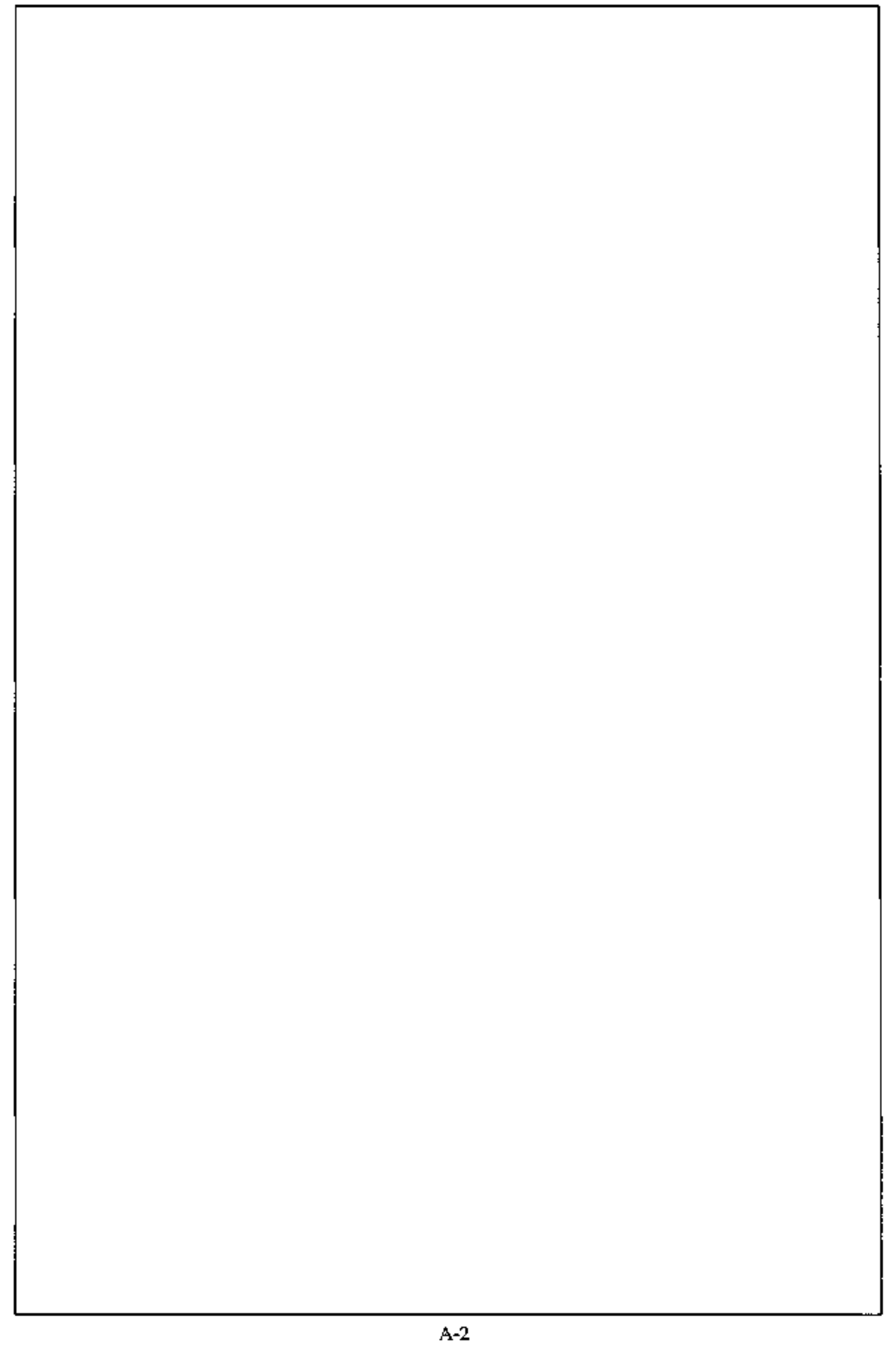




\section{FIGURES}

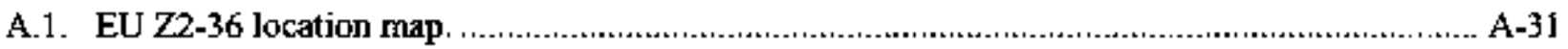

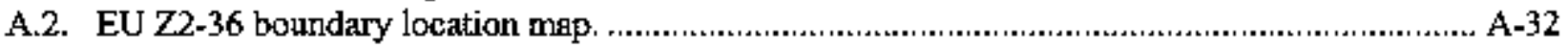

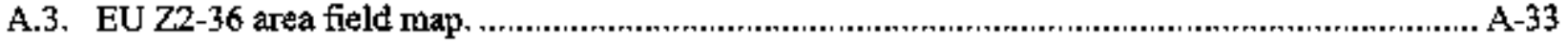

A.4, EU Z2-36 sample locations. .................................................................................................. A-34

\section{TABLES}

A.1. EU Z2-36 facility and FFA site list .......................................................................... A-35

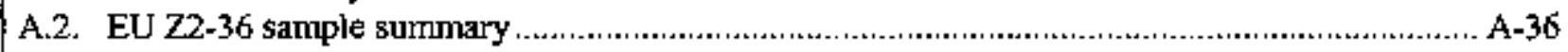

A.3. EU Z2-36 data summary for soil samples collected from 0 to $10 \mathrm{ft}$ below ground surface ......... A-38 


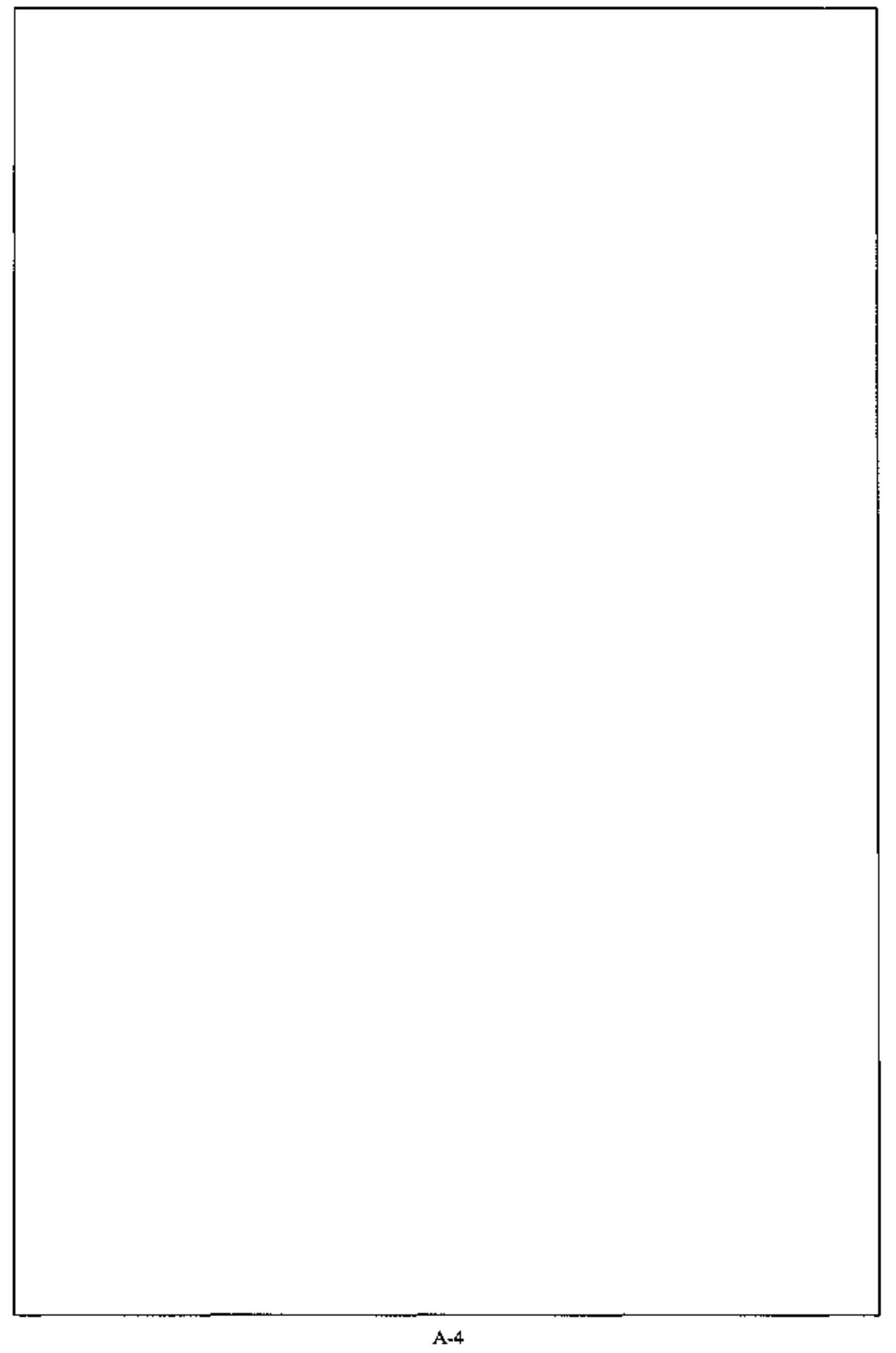




\section{DYNAMIC VERIFICATION STRATEGY (DVS) TECHNICAL MEMORANDUM}

EXPOSURE UNIT (EU) GROUP: Zone 2 Maia Plant Group EU 36

\section{INTRODUCTION}

The purpose of this Technical Memorandum (TM) is to document the recommendation for an actionino further action (NFA) decision for Zone 2 exposure unit 36 (EU Z2-36) in the Main Plant EU Group. The recommendation for this EU is based on existing historical data and DVS soil characterization activities. These data were used to determine the nature and extent of contamination in the EU and svaluate the need for ant action. When it was determined that an action was necessary, the data were also used to calculate soil volumes for the proposed remedial alternative, as identified in the Record of Decision for Soil, Butied Waste, and Substufface Structure Actions in Zone 2, East Tennessee Technology Park, Oak Ridge, Tennessee (DOE/OR/01-2161\&D2) (Zone 2 ROD).

\begin{tabular}{|l|l|}
\hline 1.0 & BACKGROLND AND EU SUMMARY \\
\hline 1.1 & LOCATION AT EAST TENNESSEE TECHNOLOGY PARK (ETTP) \\
\hline
\end{tabular}

EU Z2-36 is located in the east/central interior of Zone 2 in the Main Plant EU Group (Fig. A.1). It is bounded on the north by EUs Z2-37 and Z2-39, on the east by EUs Z2-40 and Z2-41, on the south by EUs Z2-37 and Z2-41, and on the weat by EU Z2-31.

\begin{tabular}{l|l}
\hline 1.2 & EU ACREAGE \\
\hline
\end{tabular}

EU Z2-36 has an arce of approximately 15 acres (Fig. A.2).

\begin{tabular}{l|l}
1.3 & SUMMARY DESCRIPTION \\
\hline
\end{tabular}

All of the land area in EU Z2-36 has been impacted by site operations. Impact to the EU includes the construction of buildings, roads, parking lots, and sidewalks.

The DQO Scoping Package for the Main Plant EU Group lists 42 facilities in EU Z2-36. Table A.1 presents an accounting of facilities in the EU.

\begin{tabular}{|l|l}
\hline 1.4 & SOIL UNuTS (SUs) \\
\hline
\end{tabular}

Class 1 SU: None

Class 2 SU: 2 acres

Class 3 SU: 13 acres

Class 4 SU: None

The EU Z2-36 soil unit boundaries are shown on Fig. A.2.

\section{\begin{tabular}{l|l}
\hline 1.5 & ZONE 2 ROD APPENDLX A FEDERAL FACILTTY AGREEMENT (FFA) STTES \\
\hline
\end{tabular}}

There are two FFA sites listed in Appendix A of the Zone 2 ROD as being in EU Z2-36:

- K-1098-C Asphalt Plant FFA Site

- K-1503 Neutralization Pit FFA Site

The Main Plant DQO Scoping Document places the K-1098-C Asphalt Plant FFA Site in the northeast corner of EU Z2-36 and the K-1503 Neutralization Pit south of the K-1501 Steam Plant The location of the K-1423 Grease Burial FFA Site is described in the scoping document as either east of K-1423 in EU Z2-25 or between K-1401 and the 
K-1501 Steam Plant. Subsequent to DQO scoping, further investigation showed that the former K-1098-C Asphalt Plant was located in the central portion of EU Z2-36 in an area identified in this document as the K-1501-A/B Area Class $2 \mathrm{SU}$ (Sect. 2.1.2), the K-1503 Neutralization Pit is located where it was identified during DQO scoping [which is also in the K-1501 Area Class 2 SU (Sect. 2.1.2)], and the K-1423 Grease Burial Site is located east of $\mathrm{K}-1423$ in EU Z2-25 that will be addressed in the EU Z2-25 TM.

In addition to the two FFA sites identified in EU Z2-36, a portion of the $\mathrm{K}-1401$ Acid Lines FFA site occurs in this EU. The K-1401 Acid Line FFA site witl be addressed in the EU 22-31 TM.

\begin{tabular}{|l|l|}
\hline 2.0 & \multicolumn{2}{|c}{ DVS INVESTIGATIONS AND RESLITS } \\
\hline 2.1 & DVS FIELD ACTIVITIES \\
\hline
\end{tabular}

Dynamic Verification Strategy activities were conducted in accordance with the Remedial Design ReportRemedial Action Wark Plan for Zone 2 Soils, Slabs, and Infrastructure, East Tennessee Technology Park, Oak Ridge, Tennessee (DOE/OR/01-2224\&D3) (Zone 2 RDR/RAWP).

\begin{tabular}{|l|l|}
\hline 2.1.1 & ClaSs 1 SUS \\
\hline
\end{tabular}

None

\begin{tabular}{|l|l|}
\hline 2.1.1.1 & CLASS 1 SU RADIOLOGICAL WALKOVER SURVEY \\
\hline
\end{tabular}

None

\begin{tabular}{|l|l|}
\hline 2.1 .1 .2 & CLASS 1 SU GEOPHYSICAL SURVEY \\
\hline
\end{tabular}

None

\begin{tabular}{|l|l|}
\hline 2.1.1.3 & CLASS 1 SU SOIL SAMPLING \\
\hline
\end{tabular}

None

2.1.2 CLASS 2 SUS

There are two Class 2 SUs in EU Z2-36:

K-1501-ABB Class 2 SU: The 1.8-acre K-1501-A/B Class $2 \mathrm{SU}$ is located in the central interior of the EU (Fig. A.2). The boundaries of this Class 2 SU were defined to enconpass the land area around the K-1501-A and K-150l-B Oil Storage Tank Area. The K-1098-C Asphalt Plant FFA Site is located in the central portion of this SU.

K-1501-J Class 2 SU: The 00.2-acre K-1501-J Class 2 SU is located doe east of the southern end of the K-1501-A/B Class $2 \mathrm{SU}$ and south of the K-1501 Stean Plant. The boundaries of this Class $2 \mathrm{SU}$ were defined aroumd the K-1501-J Fuel Storage Tank Area. The K-1503 Neutralization Pit FFA Site is located in this Class 2 SU.

Soll unit boundaries in EU Z2-36 are shown on Fig. A.2.

\subsubsection{1 $\quad$ Class 2 SU RaDIOLOGICAL WALKOVER SliRVEY}

With Core Team concurence, no radjation walkover surveys were conducted in EU Z2-36.

\section{\begin{tabular}{l|l} 
2.1.2.2 & ClASS 2 SU GEOPHYSICAL SURVEY \\
\hline
\end{tabular}}

None

\begin{tabular}{l|l}
$2.1 .2,3$ & CLASS 2 SU SOLL SAMPLING
\end{tabular}

K-1501-ABB Class 2 SU: There are 10 DVS systematic grid sample locations in the K-1501-A/B Class 2 SU.

K-150]-J Class 2 SU: There are two DVS systematic grid and one DVS biased sample location in the K-1501-J Class 2 SU. Soil from a third systematic grid location was screened for radiation and volatile organic compounds (VOCs) but was not sampled because the sereening levels were not exceeted (Table A.2). The biased sample 
locatoon was selected to investigate possible fuel splls at the K-1501-J Fuel Storage Tank The Ma1n Plant DQO \$coping Package describes 10 systematac gnd sample locations in the K-150I.] Class 2 \$U However, Fig 8 in the DQO Scoping Package shows three systemahc gnd sample locations. Based on the smal] size of the K-1501-J Class 2 SU, 10 systematic gnd sample locations is incorrect. The error in the DQO Scoping Packsge was described to the RA Core Team and the eurrent sampling approach in the SU was mplemented with RA Core Team concurrence.

The detarls of actul sampling and analysis in the Class $2 \mathrm{SU}$, including sample depths, analytes, and deviatons from planned sampling, are presented in Table A 2 and sample locations are shown on Fig. A.4.

\section{\begin{tabular}{l|l}
2.1 .3 & CLASS 3 AND CLASS 4 SU WALKOVER ASSESSHENT
\end{tabular}}

The protocol for addressing the Class 3 SUs in EU Z2-36 is the Class 3 and Class 4 Solt Unt Walkover Inspection Protocol, Rev. 1 (found in Appendix A of the Zone 2 RDRRAWP). The purposes of the Class 3 SU walkover assessments are to systematically inspect Class 3 SUs by visual observation along transects to establushed gind assessment locations, map observed features, and collect radologeal sereening data at gond and discretionary locations. The detals of the walkover assessment results for EU Z2-36 are presented in the document FY 2009 Walkover Inspectons and Radiological Surveys for Exposure Units in Zome 2, East Tennessee Technology Park. Oak Ridge, Tennessee (BJC/OR-3157) (Assessment Report). A summary of the report results is presentted below in Sects 2 1.3.I and 2.1.3.2. Class 3 SU boundates are shown on Fug. A.2. The assessment point (AP), mud-pount (MP), and discretuonary pount (DP) locatuons are shown on F1g A 3 .

A total of 15 APs were dentufed in EU Z2-36 prror to the start of fieldwork and are docurnented in the DQO Scoping Package. There were 16 APs evaluated in EU Z2-36

In addilon to the APs, the field team made assessments at 15 MP localons (MPs are selected in the field and are ponnts located approxumately half way between $A P$ s) and conducted duscreponary surveys at a total of 15 locatuons (see below) Mid-point and DP lacations are not specified in plannung documents Assessment pount, MP, and DP locations are shown on $F_{1} g$ A 3

\begin{tabular}{|c|c|c|c|}
\hline & $\overline{\text { Number of APs }}$ & Number of MPs & Nomber of DPs \\
\hline EU Z2-36 & 16 & 15 & 15 \\
\hline $\begin{array}{l}A P=\text { assessme } \\
D P=\text { duscretio }\end{array}$ & $\begin{array}{l}\mathrm{EU}=\text { exposure whis } \\
\mathrm{MP} \text { - mud-poind }\end{array}$ & & \\
\hline 2.1.3.1 & Class 3 avo Class 4 SU RaD & L SURVEY SUMMARY & \\
\hline
\end{tabular}

Screening level (SL) $4082 \mathrm{cpm}$

SL exceedances- None

\subsubsection{2 $\quad$ CLASS 3 AND CLASS 4 SU ANTHROPOGENIC FEATURES}

Number of identlfied anthropogenic features 15

Exposure unt Z2-36 L5 located in an industrialized portion of ETTP. As such, there are numerous anthropogenic features that consist of faciluties and associated constnucled features such as roads, sidewalks, and paved areas Plant facluties and their associated constructed features are assessed as part of the Class 3 and Class 4 SU Walkover Assessment protocol (Sect 21.3.3). Other than plant fachlues and associated constructed features, 15 anthropogentc features, corresponding to the 15 DPs, were identified in EU Z2-36 duting the Class 3 sU walkover assessment.

The anthropogenuc features identıfied un EU Z2-36 dung the Class 3 SU assessment unclude the followng:

- Gravel pad

- Sealand contanter

- Open lumber storage shed

- Sediment accumulation area at grated storm drain adjacent to loading ramp

- Document storage traler 
- Sedinent accumulation area at diesel tank dran sump

- Electrical supply bulding

- Gas cylinder storage shed

- Flammable materials storage shed

- Metal storage buildng

- Break tratier

- Graled storm drasu catch basin

- Change house trayler

- Concrete block storage area

\subsubsection{3 $\quad$ CLASS 3 SU FACILTTIES ALSESSMENTS}

Forty-two facilites are listed un the DQO Scopung Package as being located un EU Z2-36 and 45 facluthes were assessed during the Class 3 SU walkover assessment (Table A 1) The factity assessments are reported to the Assessment Report In summary, no faclity was identified as a possible scurce for elther chemical or radiological contamination

\subsubsection{4 $\quad$ CLASS 3 AND CLASS 4 SU B]ASED SAMPLING}

Based on radiation surveys and visual assessment of each anturopogenic feature for evidence of possible contammation, no biased sample locations were selected during the Class $3 \mathrm{SU}$ walkover assessment

There are nune DVS brased sample locations that wll be addressed as Class 3 SU sample locatons Two of the locations are whthin the K-150l Area Class 2 SU but because they address DQO scoping Class 3 SU sampling requirements, they will be addressed as Class $3 \mathrm{SU}$ sample Jocations (see below)

- As requred by DQO scoping, there are six biased sample locations associaled whth three stom drans in EU Z2-36 One sample location at each storm dram 18 for collection of sedment from the stonu drain and the other location is for soll from outside the stom drain The three storm drauns addressed by DVS samplung are the stom dram junchon located east of K-1401 along Avenue $\mathrm{D}_{\text {s }}$ a stom drat southeast of K-1501, and a storm drain northwest of $\mathrm{K}-1501$ The storm drain trotthwest of K-1501 is actually focated in the K-1501 Area Class 2 SU (Sect 21 2) but sampleng is addressed as Class 3 SU samplung to be consistent with DQO scopmg The DQO Scoping Package specifically identifies the K-1401 storm drain for sampling Thus DQO scoping requirement is fulfilled by sampling at the three storm drains

- As required by DQO scoping, there are two biased sample hocations un the former coal yards in EU Z2-36 A four-point composite sample was colfected from the K-150l.N Coal Yard and another four-point composite sample was collected at the K-150I-S Coal Yard

- One brased sample location was identafied at the mmp located east of the K-1501 Stean Phant pror to a remedial action conducted at the sump Thus sampling location was added whth Core Team concurrence

Data qualty objectuve scoping speesfied that a sample of sediment or shudge would be collected from the K-1204-05 Sewage Ejector Station Duning feld work il was determined there was no sediment or sludge from the sewage ejector station Because of the absence of matersals that might pose a risk to the indurstrial worker, sampling at the proposed localion was dropped wth Core Team concurrence

The detals of actual sampling and andlysis in the Class $3 \mathrm{SU}$, including sample depths, analytes, and devathons from planned sampling, are presented in Table A 2 and sample locations are shown on Fig A 4

\section{\begin{tabular}{|l|l}
2.2 & DVS AND HISTORICAL SAMPLE RESULTS \\
\hline
\end{tabular}}

Sample data for DVS and hustoncal sampling in EU Z2-36 are summanzed in Table A 3 The total number of samples referred to in the table is a coubunation of all sample results The presettation of sample resuits in Sect 225 summanzes subsets of Table A 3 by presenting pertment results for focused charactenzation unitun EU 22-36 Sample locations are shown on Fig A 4 A compact disc contauning electronje files for the hustorical and 
DVS analytical data used to gentrate the data tables is provided with the Phased Constructuon Completion Report (PCCR)

\section{\begin{tabular}{l|l} 
2.2.1 & CLASS 1 SUS \\
\hline
\end{tabular}}

None

$\mathbf{2 . 2 . 2}$

Class 2 SUS

There are 13 DVS sample locatons in the K-1501 Area Class 2 SU and no hrstoncal sample locatuons Class 2 SU sample locations are stown on Fig A 4 and summarized below

\begin{tabular}{l}
\hline \multicolumn{1}{c}{ DVS sample locations } \\
\hline K-1501-AB Class 2 SU Systematic Grld \\
Lotitions: \\
Z2-EU36M-200, Z2-EU36-201, Z2-EU36-202, \\
Z2-EU36-203, Z2-EU36-204, Z2-EU36-205, \\
Z2-EU36-206, Z2-EU36M-207, Z2-EU36-208, \\
Z2-EU36-209 \\
K-1501-J Class 2 SU Systematlc Grtd \\
Locations \\
Z2-EU36-210, Z2-EU36-211 \\
K-1501-J Class 2 SU Biased Location: \\
Z2-EU36-213
\end{tabular}

DVS - Dynamuc Venficatem Strategy

$\$ \mathrm{U}=$ soll uat

Sampling and analytical detals for each sample location are presented in Table A 2 The analytical data are summarized in Table A 3 and evaluated in Sect 225 The number of anatyses conducted in the Class 2 SU is presented below by analyte group

\begin{tabular}{cccccc}
\hline Metals & $\begin{array}{c}\text { Ocher } \\
\text { organics }\end{array}$ & PPCBs & Radionuclides & SVOCs & VoCs \\
\hline 18 & 7 & 12 & 5 & 12 & 7 \\
\hline
\end{tabular}

"Theludes diesel range organucs (DRO) and gasolune range organcs (GRO)

PPCB a pesucrde and polychlonanted buphenyl

$S W O C=$ semivolatele organic compound

$\mathrm{VOC}=$ volatile organic compound

\section{\begin{tabular}{l|l}
2.23 & CLASS 3 AND CLASS 4 SUS \\
\hline
\end{tabular}}

There are 23 DVS and hustorical Class 3 SU sample locations in EU Z2-36, Including two sample locations that actually fall in the K-1501 Area Class 2 SU but are addressed as Class 3 SU sample location to mantain consistency with DQO scoping requrements Histoncal sampling was conducted dunng complance sampling and the ETTP Release Site Project Class 3 SU sample locations ate shown on Fig A 4 and summarized below

\begin{tabular}{|c|c|}
\hline DVS sample lacations & Histarical sample lacations \\
\hline $\begin{array}{l}\text { K-1401 Storm Drain: Z2-EU36B-301 (storm drain } \\
\text { sedıment), Z2-EU36B-302 (soll) }\end{array}$ & $\begin{array}{l}\text { ETTP-REL05, ETTP-REL06, ETTP-RELO7, } \\
\mathrm{SO1}, \mathrm{S} 02, \mathrm{~S} 03, \mathrm{SO4}, \mathrm{S} 05, \mathrm{~S} 06, \mathrm{~S} 07 . \mathrm{S} 08, \mathrm{~S} 09, \\
\mathrm{~S} 10, \mathrm{~S} 11\end{array}$ \\
\hline
\end{tabular}

Storm Drain Northwest of K-1501-H: Z2-EU36B-307

(storm draun sedument), Z2-EU36B-308 (soll) 
Storm Drain Sontheast of K-1301-H: 22-EU36B-303

(storm drain sedunent), Z2-EU36B-304 (soll)

K-1501-N Coal Yard: Z2-EU36B-305

K-1501-S Coal Yard: Z2-EU36B-306

Sump East of K-1501: Z2-EU36B-310

Sampling and analytical detals for each sample location are presented in Table A 2 The analytical data are summarzed in Table A 3 and evalualed in Sect 225 The aumber of analyses conducted in the Class 3 SU is presented below by analyte group

\begin{tabular}{cccccc}
\hline Metals & $\begin{array}{c}\text { Other } \\
\text { organics" }\end{array}$ & PPCBs & Radionuclides & SVOCs & VOCs \\
\hline 14 & I & I5 & 19 & 15 & 11 \\
\hline "Incledes DRO and GRO & & & &
\end{tabular}

PPCE = pesticide and polychtornatad buphenyl

SWOC = acmivolatile orgatice compound

VOC = yolatıle orgenic compourd

\section{\begin{tabular}{|l|l}
\hline 2.2 .4 & INFRASTRUCTURE SAMPLING \\
\hline
\end{tabular}}

Dyname Venfication Strategy Class 3 SU biased sampling of storm drams was conducted

\begin{tabular}{|l|l}
\hline $\mathbf{2 . 2 . 5}$ & EU EVALUiATION \\
\hline
\end{tabular}

Characternzation data and other mformation are evaluated for EU Z2-36 in ths section Analytical data in the followng summanes are presented by analyte group and results for a particular analyte group are surnmanzed only If that group was analyzed on the samples from the unt being summanzed Within each summary, the data are evaluated by comparing to centain criteria, including the Zone 2 solls maxumum jemediation level (Max RL), Zone 2 sorls average remediation level (Avg RL), $1 \times 10^{5}$ industral prelimunary remediatoon goal (Ind PRG), ETTP soLs background composition (Bkg), Zone 2 groundwater screenng levels (GW SL), and $1 \times 10^{6}$ residental prelıminary remediation goal (Res PRG) If a particular critemon does not apply to any member of an analyte group, tt is not tabulated for that analyte group if a partucular criterion does not apply to all analytes withon an analyte group, those anaiytes to which it does not apply were notated wth NA (not applucable) Indivdual metals and radionuclides, which are naturally occusring, are reported in the summaries only of one or more conterion is exceeded Organic chemicals, which are not naturally occurning, are reported of they are detected even if no cntena are exceeded The Max RL, Avg RL. Ind PRG, Bkg, GW SL, and Res PRG cnterıa values are presented in Sect 31 of this PCCR as they pertam to the analytes listed in Appendix A of the RDRRAWP ( $\mathrm{e}$, the QAPP)

Because the carcinogenic rusk assoclated whth the concentranons of radum and thonum 1sotopes in the manural background at ETTP exceeds the cumulative risk goal of $1 \times 10^{4}$, RL values for these radionucludes are based on alternatuve concentration levels rather than nsk The altematnve concentration levels of $5 \mathrm{pCl} / \mathrm{g}$ above background (Avg RL) and $15 \mathrm{pCL} / \mathrm{g}$ above background (Max RL) were set as low as reasonably achevable under the ste-specific conditions Because site-specific background concentrations of these radionuclides exceed the target nsk range, residual conemtrations of these radiontucludes and ther decay series are not considered in estrmates of residual risk followiog any remedial action

The Zone 2 ROD states that Avg RL and Max RL exceedances by Ra-226, Th-230, and Th-232 w1l be evaluated by summing above-background concentrations of the greater of Ra-226 or Th-230 with the above-background concentrations of Th-232 and companng the results to $5 \mathrm{pCV} / \mathrm{g}$ (average RL) and $15 \mathrm{pCv} / \mathrm{g}$ (maximum RL) These required calculations bave been performed Average and Max RL exceedacces for these radronuclides, if any, are reported in the TM data summaries below and in Table A 2 as "Ra/Th tecay senes", and individual RL exceedances 
by $R a-226$, Th-230, and Th-232 are reported as NA. The Ra/Th decay series data are summarized in the sections that follow only if an Avg or Max RL bas been exceeded consistent with the description in the preceding paragraph for reporting radionuclides. Discussion of the Ra/Th decay series calculation, including the manner in which the calculation is performed, is presented in Sect. 3.3 of this PCCR

\section{EU Z2-36 Conceptual Site Model (CSM)}

The 15-acre EU Z2-36 is located in the eastern portion of the Main Plant EU Group north of the K-1070-C/D waste disposal area. Of the 15 acres, 1.8 acres were classified as a Class $2 \mathrm{SU}$ enconpassing the K-1501-A and K-1501-B Diesel Storage Tanks and a small Class $2 \mathrm{SU}$ (less than a 0.2 acre) around the K-1501-J Fuel Storage Tank The remaining 13 acres were classified as a Class 3 SU.

There are two FFA sites in EU Z2-36 (K-1098-C Asphalt Plant and K-1503 Neutralization Pit) and 42 facilities are listed in the DQO Scoping Package as occuring in the EU. The K-1098-C Asphalt Plant ceased operations in the 1950 s and was removed from the site in the early 1960s. The K-1503 Neutralization Pit was filled with concrete in the I980s when it was found to be leaking. This pit was backfilled as part of the K-150I Demolition Project. Most of the facilities in the EU bave been removed as part of ongoing decommissioning and demolition (D\&D) projects. The K-1501 Steam Plant and all of the associated building structures and facilities that were formerly located in the eastem portion of the EU have been removed and the subsurface structures, including the K-1501 building basement, have been backfilled with clean soils. The oniy peruanent structure that remains in EU $22-36$ is the K-1400 office building. Trailers and other temporary office structures bave been removed and replaced with new trailers within the last several years as part of the ongoing site dernolition program.

There is one CSM related to the possible release of contaminants in EU Z2-36. The CSM is a surface release model related to fuel storage facilities in the EU. There was a known spill from the K-1501 Diesel Storage Tank in 2000. The size of the spill was substantial but the spill was generally contained within the containraent dike around this large aboveground storage tank and the fuel was pumped into temporary storage tanks to remove it from the area. Surface releases of fuels for the K-1501 Steam Plant also may have occurred at the K-1501-J Fuel Storage Tank, another aboveground tank Sanopling in the EU during DQO scoping focused on the potential for releases of diesel and other fuels to surface soils. Spilled fuels generally are known to have entered the storm drain system that discharges through the K-170 storm drain to the north into Milchell Branch. Stom drain sediment and surrounding soil were sampled at three storm drains in EU Z2-36 and no contamination was identified. In addition, soil sanples collected as part of the DVS sampling program did not identify any areas of substantially contaminared soils above Zone 2 RLs or above industrial use PRGs.

The Class $3 \mathrm{SU}$ areas were evaluated according to the approved Class $3 \mathrm{SU}$ walkover assessment protocol. No samples were added to the base program based on observations made during these assessments.

\section{EU Z2-36 Gronndwater Evaluation}

There are seven groundwater monitoring wells in EU Z2-36 and two collection sumps where infiltrating water is monitored for the presence of contaminants. Groundwater flow in the area is from the topographic high ground to the south that underlies EU Z2-41 (K-1070-C/D) where waste storage yards and disposal trenches were located. Three monitoring wells are located along the south boundary of the EU. A bedrockunconsolidated zone well pair, BRW-012/UNW-019, and a single unconsolidated zone well point, UNP-001, are located north of the Patrol Road on the north flank of the high ground. A single bectrock well, BRW-070, is located in the west central portion of the EU north of the former coal storage yard. A single unconsolidated zone monitoring well, UNW-056, is located immediately south of the former steam plant building location, and a bedrock/unconsididaled zone well pair, BRW-048/UNW-092, is located north of the Stean Plant and downgradient of the former diesel storage tank location. In addition to these groundwater monitoring wells, the water collected in the French drain system around the K-1400 building is monitored at location K-1400 FR-DRAIN and a collection sump east of Avenue D is monitored at location K-1070-TR-EF. 


\begin{tabular}{lclcc|}
\hline \multicolumn{1}{c}{ Locration D } & Date drilled & \multicolumn{1}{c}{ Interval } & Screen depth & $\begin{array}{c}\text { Monitoring } \\
\text { period }\end{array}$ \\
\hline BRW-012 & 1987 & Bedrock/abandoned & $112-132 \mathrm{ft}$ & $1987-1998$ \\
BRW-048 & 1989 & Bedrock & $56-66 \mathrm{fi}$ & $1989-1995$ \\
BRW-070 & 1989 & Bedrock/abandoned & Open hole to $83 \mathrm{ft}$ & $1989-1995$ \\
UNW-019 & 1987 & $\begin{array}{l}\text { Unconsolidated zone/ } \\
\text { abandoned }\end{array}$ & $25-35 \mathrm{ft}$ & $1989-1995$ \\
UNW-056 & 1987 & Unconsolidated zone & $5.5-10.5 \mathrm{ft}$ & $1989-1995$ \\
& 1989 & Unconsolidated zone & $13.5-18.5 \mathrm{ft}$ & $1989-1998$ \\
UNW-092 & & & & \\
UNP-001 & 1985 & Unconsolidated zone & $22.5-27.5 \mathrm{ft}$ & $1986-2008$ \\
K-1400-FR-DRALN & NA & Open catchment & NA & 2006 \\
K-1070-TR-EF & NA & Open catchment & NA & $2002-2003$ \\
\hline
\end{tabular}

Depth to water varies in the unconsolidated zone wells localed on the slope of the hill ailong the south EU boundary from approximately 12-20 ft bgs. Depth to water in wells further north in the flat ground around the K-1501 steam plant and the former diesel storage lank is sear the ground surface, ranging fom as littic as $1.7-6.1 \mathrm{ft}$ bgs. The potentionetric surface in the bedrock wells range from 13-20 ft bgs in BRW-012 located on the slope, 7-9 ft bgs in BRW-048 in the north portion of the EU, and from surface to artesian in BRW 070 , which is located in the west central portion of the site. Vertical gradients vary seasonally both spatially and temporally over the EU. Horizontal gradients are toward the north and are presumed to be bigher along the south boundary and flatten across the broad area to the north flowing toward Mitchell Branch. Three of the monitoring wells were closed and abandoned in 2002, incluting the well pair along the southem EU boundary and the bedrock well in the west centrat portion of the EU that exhibited artesian flow.

Substantial groundwater contamination in the EU is observed over the entire historic monitoring period in only one well, UNP-00l, which is localed along the southern EU boundary and downgradient of a former waste dnum storage yard located in the northwestem portion of EU Z2.41. The sourse location was identified in the investigation work performed in EU Z2-41, bowever no localized source of soil contamination was identified in the former waste storage yard Contaminants present in groundwater from UNP-DOl inchde several VOCs (tetrachIoroethene and its degradation products trichloroethene, dichloroethene, and vinyl chloride). Concentrations of these contaminants over the historic monitoring period (1989-2007) show minimal decline of the tetrachloride compound but show declining concentrations of the degradation products. This monitoring well location is near the EU boundary and historic records show the contaminant source area is to the south, outside of EU Z2-36 in EU Z2-41.

\section{EU Z2-36 Sampling Results}

The 15-acre EU Z2-36 has been classified into two Class 2 SUs covering 2 acres, with the remaining 13 acres classified as a Class 3 \$U. The EU lies in a heavily industrialized portion of Zone 2 and the land area has been densely populated by buildings, other facilities, and paved areas such as sidewalks, roads, and parking lots. Many of the buildings and other facilities have been removed as part of the D\&D Program at ETTP.

The $\mathrm{K}-1501-\mathrm{A} / \mathrm{B}$ Class $2 \mathrm{SU}$ (1.8 acres) encompasses the land area around the former K-1501-A and K-1501-B Oil Storage Tarks. There are 10 DVS systematic grid sample locations in this Class $2 \mathrm{SU}$ (Sect. 2.2.2). Two biased sarmple locations at a stom drain also occur in this Class 2 SU but the analytical data are evaluated as Class 3 SUs data because the sample locations were specified as part of the Class $3 \mathrm{SU}$ satnpling requirements during DOO scoping. The K-1098-C Asphalt Plant FFA Site is located within the boundaries of the K-1501-A/B Class 2 SU. The $\mathrm{K}-1501-\mathrm{J}$ Class $2 \mathrm{SU}$ (approximately $0.2 \mathrm{acre}$ ) is located to the east of the southern portion of the $\mathrm{K}-1501-\mathrm{A} / \mathrm{B}$ Class $2 \mathrm{SU}$ and excompasses the land area around the former K-1501-J Oil Storage Tank. There are two DVS systematic grid sample locations and one DVS biased sample location in the K-1501-J Class 2 SU (Sect. 2.2.2). The K-1503 Neutralization Pit FFA Site is located within the boundaries of the K-lS01-J Class 2 SU.

A Class 3 SU walkover assessment was conducted ove the Class 3 SU in EU Z2-36. Because the EU is located in an industrialized portion of ETTP, anthropogenic features are common. However, many of the anthropogenic features are facilities or the remains of facilities that have been demolished. Forty-five facilities were evaluated as part of the Class $3 \mathrm{SU}$ walkover assessment (Sect. 2.1.3.3) but no biased sampling was conducted based on nadiation 
surveys and visual observations No other anthropogence feamires were identified for biased sampling durung the Class 3 SU walkover assessment (Sect 2132 ) Three stom drain sample pars (one sample of storm dram sedument and the other sample of sol from outside the storm draw) were specified dung DQO scopung All sIX sample locations were identified and sampled dung DVS activitues One of the stonm drains 1 located mi the $\mathrm{K}-1501-\mathrm{A} / \mathrm{B}$ Class 2 SU but is evaluated as Class 3 SU sampling to be consistent with DQO scopung requirements Two four-point composite DVS biased sample locations also were sampted in the Class $3 \mathrm{SU}$ as specified dungg DQO scoping, one each is the K-1501-N and K-1501-S Coal Yards A DVS biased sample also was collected at the sump located east of the $K-1501$ Steam Plant prior to a remedial acton at the sump Finally, there are 14 histonca sample locatons in the Class 3 SU that were sampled as part of the ETTP Release Ste Project and complance sampling None of the histoncal sample locations are associated wath features of unterest identafied dunng DQO scoping or with FFA sites

Followng are summanes of the focused investgation areas in EU Z2-36 Focused mvestagation areas molude the K-1501-A/B Class 2 SU, K-1501-J Class 2 SU, K-1501-N and K-150I-S Coal Yards, K-1501 sump, storm drans on EU Z2-36, and other Class 3 SU sample locations not assocrated with any particular feature or FFA site in the EU Following the focused investugation summanes is an EU Z2-36 summary, which includes both data summary tables and a wniten descripton of the nature and extent of the chemicals and radionuclides observed in the EU The summary mcludes all data from the EU Detads of samplong and analyss at each sarnple location in EU Z2-36 are presented in Table A 2, a summary of all EU data is presented in Table A 3, and sample locabons are shown on Fig A 4

K-1501-A/B Class 2 SU: There are 10 DVS systematic gnd sanple locations in the K-1501-A/B Class 2 SU (Sect 22 2) Analytical results from the DVS sampling in this Class 2 SU also serve to charactenze the K-1098-C Asphalt Plant FFA Stte Aralytical results from the 10 sample locatons summarzed below show radionuclide and one SVOC Ind PRG exceedances, metal and radiontulide Bkg exceedances, and detechons of DRO, GRO, PCBs, SVOCs, and VOCs

EU Z2-36 K-1501-A/E CLASS I SU METALS WITH BACKGROUND, PRG, GW \&L, AND/OR RL EXCEEDANCES (me/kg) 0-10 it

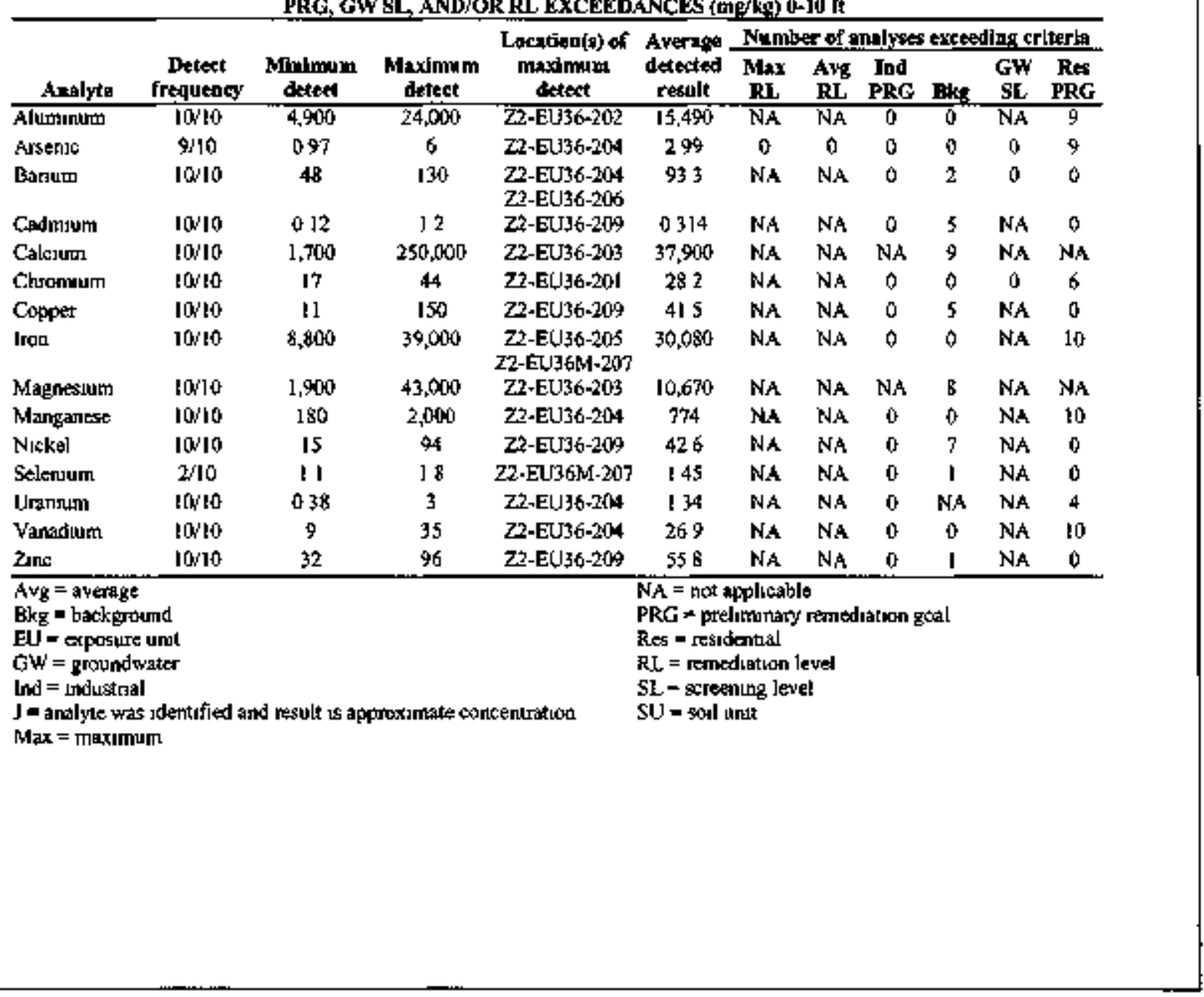


EU Z2-36 K-1501-AMB CLASS 2 SU OTTHER ORGANICS DETLCTS (mg/kg) 0-10 ft

\begin{tabular}{|c|c|c|c|c|c|}
\hline Antlyte & $\begin{array}{l}\text { Dexest } \\
\text { trequensy }\end{array}$ & $\underset{\substack{\text { Minimmm } \\
\text { detext }}}{ }$ & $\begin{array}{c}\text { Maximmm } \\
\text { detext }\end{array}$ & 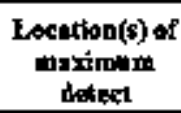 & $\begin{array}{l}\text { Aversige } \\
\text { datected } \\
\text { result }\end{array}$ \\
\hline Ditesct Range Organiks & 1,6 & $860 \mathrm{~J}$ & 800, & $22-E 036-208$ & 860 \\
\hline Gasoline Range Onganics & $3 i 6$ & $0.16 \mathrm{~J}$ & 25 & Z2-EU36-208 & 9.65 \\
\hline
\end{tabular}

EU ZZ-36 K-150]-A/B CLASS 2 SU PPCCB DETECTS (ug/kg) 0-10 ft

\begin{tabular}{|c|c|c|c|c|c|c|c|c|c|}
\hline \multirow[b]{2}{*}{ Analyte } & \multirow[b]{2}{*}{$\begin{array}{c}\text { Dotect } \\
\text { frequenky }\end{array}$} & \multirow[b]{2}{*}{$\begin{array}{c}\text { Mininaun } \\
\text { detect }\end{array}$} & \multirow[b]{2}{*}{$\begin{array}{c}\text { Maximum } \\
\text { detect }\end{array}$} & \multirow{2}{*}{$\begin{array}{c}\text { Location(s) of } \\
\text { minimber } \\
\text { detect }\end{array}$} & \multirow{2}{*}{$\begin{array}{l}\text { Averaget } \\
\text { detected } \\
\text { repult }\end{array}$} & \multicolumn{4}{|c|}{$\begin{array}{l}\text { Namber of onalyses } \\
\text { expeeding erilerie }\end{array}$} \\
\hline & & & & & & $\begin{array}{c}\text { Max } \\
\text { RL }\end{array}$ & $\mathrm{AL}$ & $\begin{array}{l}\text { Ind } \\
\text { FRG }\end{array}$ & $\begin{array}{l}\text { RE: } \\
\text { PRG }\end{array}$ \\
\hline PCE-1254 & $1 / 10$ & $8.1 \mathrm{~J}$ & 8.JJ & Z2.EU36-206 & 8.1 & 0 & 0 & 0 & 0 \\
\hline PCB-1260 & $4 / 10$ & IIJ & 78 & Z2-EU36M-200 & 40 & 0 & 0 & 0 & 0 \\
\hline Polychlorinated tiphenyl & $\$ 10$ & $8.1 J$ & 78 & $27-E U \div 36 \mathrm{M}-200$ & 33.6 & 0 & 0 & 0 & 0 \\
\hline
\end{tabular}

AYQ = average

EU = exposure utit

Ind $\mathrm{x}$ incustrial

$J=$ anglyle was idencified and result is appoxiluate conkentration

Max = maximum
PPCB - pesticide and polycblorinated biphenyl

PRS a preliminary remediation goal

Rers a rasidenlial

RL = remedjation kevel

$\mathbf{S U}=\mathbf{s o j l}$ unit

EU Z3-36 K-150]-A/B CLASS 2 SU RADIONUCLIDES WTTH BACKGROUND, PRG, ANDOR RL EXCEEDANCES (pCis) 0-to ft

\begin{tabular}{|c|c|c|c|c|c|c|c|c|c|c|c|}
\hline \multirow[b]{2}{*}{ Analyte } & \multirow[b]{2}{*}{$\begin{array}{c}\text { Detett } \\
\text { frequexcy }\end{array}$} & \multirow[b]{2}{*}{$\begin{array}{l}\text { Miniman } \\
\text { detext }\end{array}$} & \multirow[b]{2}{*}{$\begin{array}{c}\text { Maximum } \\
\text { detect }\end{array}$} & \multirow[b]{2}{*}{$\begin{array}{l}\text { Lacution(g) of } \\
\text { quakimnm detect }\end{array}$} & \multirow{2}{*}{$\begin{array}{c}\text { Averiege } \\
\text { detected } \\
\text { result }\end{array}$} & \multicolumn{6}{|c|}{ Nomber of analyses exceed ln chiterin } \\
\hline & & & & & & $\begin{array}{c}\text { Max } \\
\text { RL }\end{array}$ & $\begin{array}{l}\text { Avr } \\
\text { RL }\end{array}$ & $\begin{array}{l}\text { Ind } \\
\text { PRG } \\
\end{array}$ & Bkg & $\begin{array}{l}\text { GW } \\
\text { SLL }\end{array}$ & $\begin{array}{l}\text { Res } \\
\text { PRG }\end{array}$ \\
\hline Potassium-40 & $4 / 4$ & 198 & 24 & Z2-EU36-209 & 21.6 & $\mathrm{NA}$ & NA & 4 & 0 & NA & 4 \\
\hline Thorium-228 & $4 / 4$ & 1.28 & 1.64 & Z2-EU36-204 & \rfloor .43 & NA & NA & 4 & 0 & $N / A$ & 4 \\
\hline Thoriumz-230 & $4 / 4$ & $0.828 \mathrm{~J}$ & 1.51 & Z2-투) & 1.07 & NA & $\mathrm{NA}$ & 0 & l & NA & 0 \\
\hline Thoriurun-232 & $4 / 4$ & 1.12 & 1.87 & Z2-EU36-201 & 1.43 & $\mathrm{NA}$ & NA & 4 & 0 & NA & 4 \\
\hline Utanium-238 & $4 / 4$ & 0.955 & 1.88 & $22-E U 36-2,09$ & 1.41 & 0 & 0 & 0 & 2 & D & 4 \\
\hline
\end{tabular}

Avg = average

Bkg $a$ background

$E U=$ exposire unil

GW' = groundwater

lod $=$ industial

J = analyte was idendified and retal it approximale conemtration $\mathrm{NA}_{\mathrm{A}}=$ not applicable

PRG - preliminaty remediation gơal

Res = rosidential

RL = remediatian level

SL = screetillg level

SU = toil unit

Max = maximum

EU Z2-36 K-150]-AB CLAS\$ Z \$U \$VOC DETECTS (ua/kg) 0-10 ft

\begin{tabular}{|c|c|c|c|c|c|c|c|c|}
\hline \multirow[b]{2}{*}{ Anglyte } & \multirow[b]{2}{*}{$\begin{array}{l}\text { Deteet } \\
\text { frequency }\end{array}$} & \multirow[b]{2}{*}{$\begin{array}{c}\text { Miniman } \\
\text { detect }\end{array}$} & \multirow[b]{2}{*}{$\begin{array}{c}\text { Maximum } \\
\text { detect }\end{array}$} & \multirow[b]{2}{*}{$\begin{array}{l}\text { Locutisen(t) of } \\
\text { manimu re detect }\end{array}$} & \multirow{2}{*}{$\begin{array}{l}\text { Average } \\
\text { detected } \\
\text { result }\end{array}$} & \multicolumn{3}{|c|}{ 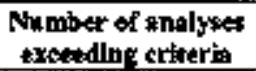 } \\
\hline & & & & & & $\begin{array}{l}\text { Ind } \\
\text { PRG }\end{array}$ & $\begin{array}{l}\text { GW } \\
\text { SL }\end{array}$ & $\begin{array}{l}\text { Res } \\
\text { FitG } \\
\end{array}$ \\
\hline 2-Methylvaphthakene & $4 / 0$ & $91 \mathrm{~J}$ & 10,000 & Z2-EU36-203 & 2,608 & 0 & $\mathrm{NA}$ & l \\
\hline Acenaphitiene & $1 / 10$ & 520 & 520 & 72-EU36-203 & 520 & 0 & $N_{A}$ & 0 \\
\hline Acenaphihylene & $2 / 10$ & \$4J & $150 \mathrm{~J}$ & ZZ-EU $36-209$ & 117 & 0 & NA & 0 \\
\hline Arthriacene & $2 / 10$ & $8 \mathrm{IJ}$ & 680 & 22.EU36-203 & 381 & 0 & NA & 0 \\
\hline Berro(a)enthricene & $1 / 10$ & 2700 & 2,700 & Z2-EU36-209 & 2,700 & 0 & NA & l \\
\hline Betzot(日)pytene & $1 / 10$ & $4,000 \mathrm{~J}$ & $4,000 \mathrm{~J}$ & Z2-EU36-209 & 4,000 & $\mathbf{I}$ & NA & l \\
\hline Benzo(b)iluotanthene & 2110 & $120 J$ & $8,800 \mathrm{~d}]$ & 72-EU36-209 & 4,460 & 0 & $N_{A}$ & l \\
\hline Betzon(ghi)perylese & $1 / 10$ & $3,200 \mathrm{~J}$ & $3,200 \mathrm{JJ}$ & Z72-EU36-209 & $3,2 \infty$ & 0 & NA & 0 \\
\hline Benzo(k)filuoranthene & $1 / 10$ & 2,7001 & $2,700 \mathrm{~J}$ & Z2.EU36-2009 & 2,700 & 0 & $\mathrm{NA}_{\mathrm{A}}$ & 0 \\
\hline Carbarosle & $1 / 10$ & $120 \mathrm{~J}$ & $120 \mathrm{~J}$ & Z2-EU36-203 & 120 & 0 & NA & 0 \\
\hline Chrysene & $1 / 10$ & 2,100 & 2100 & Z2-EU36-209 & 2,100 & 0 & $\mathrm{NA}$ & 0 \\
\hline Dibertu(a,h)arthracene & $1 / 10$ & 7800 & TBOA & Z2-EU36-209 & 780 & 0 & $\mathrm{NA}$ & $\mathrm{l}$ \\
\hline Dibetzofüran & $1 / 10$ & 2701 & $230 \mathrm{~J}$ & $22-E \bigcup 36-203$ & 270 & 0 & NA & 0 \\
\hline Fluoranthene & $2 / 10$ & $13 ß J$ & 2,600 & 己2.EU36-209 & 1,365 & 0 & $\mathrm{NA}$ & 0 \\
\hline Fhuorente & $1 / 10$ & 350 & $\tau \xi 0$ & Z2-EU36-203 & 750 & 0 & $\mathrm{NA}$ & 0 \\
\hline Indeto $(1,2,3 \leadsto$ d 3 pyrene & $1 / 10$ & $3,000 \mathrm{~J}$ & $3,000 \mathrm{~J}$ & 22-EU36-209 & 3,000 & 0 & NA & l \\
\hline Naphahaleme & 616 & 76 丁 & $3,400 \mathrm{~J}$ & 22-EU36-208 & $1,5.51$ & 0 & NAs & 1 \\
\hline
\end{tabular}


EU Z2-36 K-1501-A'B CLASS 2 SU SVOC DETECTS (ug/kg) 0-10 ft (cont.)

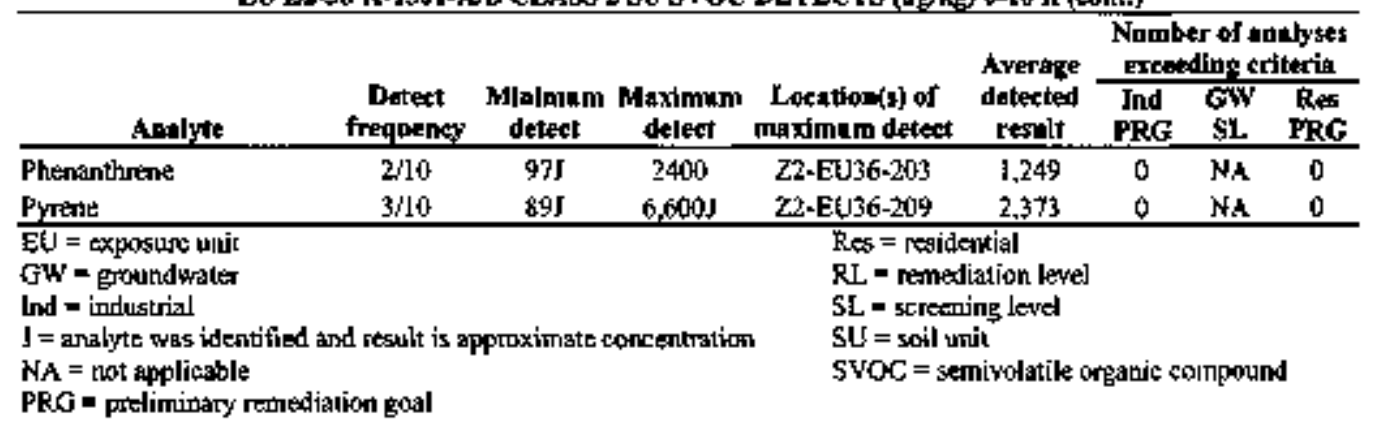

Ed Z2-36 K-1501-A/B CLASS 2 SU VOC DETECTS (ug/kg) 0-10 ft

\begin{tabular}{|c|c|c|c|c|c|c|c|c|}
\hline \multirow[b]{2}{*}{ Annlyte } & \multirow[b]{2}{*}{$\begin{array}{c}\text { Deteed } \\
\text { fruquiney }\end{array}$} & \multirow[b]{2}{*}{$\begin{array}{l}\text { Minirinum } \\
\text { detect }\end{array}$} & \multirow[b]{2}{*}{$\begin{array}{c}\text { Mexlmum } \\
\text { detext }\end{array}$} & \multirow[b]{2}{*}{$\begin{array}{l}\text { Locelion(s) of } \\
\text { moximum detect }\end{array}$} & \multirow{2}{*}{$\begin{array}{l}\text { Averisto } \\
\text { dittortid } \\
\text { result }\end{array}$} & \multicolumn{3}{|c|}{$\begin{array}{l}\text { Number of analyses } \\
\text { exceedling criteriti }\end{array}$} \\
\hline & & & & & & $\begin{array}{l}\text { lnd } \\
\text { PRG }\end{array}$ & $\begin{array}{l}\text { GUY } \\
\text { SL }\end{array}$ & $\begin{array}{l}\text { Rots } \\
\text { PRG }\end{array}$ \\
\hline (1,1-Dimethyletby]\}beazene & $1 / 6$ & 390 & 390 & 22-E』36-2008 & 390 & 0 & NA & 0 \\
\hline ( I-Metbyipropyl)benzene & $2 / 6$ & 21 & 1,300 & Z2-EUJ $6-208$ & 661 & 0 & NA & 0 \\
\hline 1,2,4-Trimethylbenzene & $2 / 6$ & 4.5J & 47,000 & Z2-EV/36-208 & 23,502 & 0 & NA & 1 \\
\hline 1,2-Dichkmpropsnc & $1 / 6$ & 2501 & 2501 & Z2-EบJ6-208 & 250 & 0 & NA & 0 \\
\hline 1,2-Dinethylbenzene & $1 / 6$ & 23,000 & 23,000 & Z2-EU36-208 & 23,000 & 0 & Nh & 0 \\
\hline 1,3,5-Trimethylbenzene & $1 / 6$ & 20,000 & 20.000 & 20-EU36-208 & 20,000 & 0 & NA & ! \\
\hline $\begin{array}{l}\text { 1-Methyl-4-(1-wethylethyl) } \\
\text { bentedte }\end{array}$ & $2 / 6$ & 14 & 3,800 & 22-EU36.208 & 1,907 & NA & $N A$ & NA \\
\hline 2-Élanonc & $1 / 6$ & 8.3. & $8.3 \mathrm{~J}$ & 27 -Eบ36-203 & 8.3 & 0 & NA & 0 \\
\hline Astonk & $1 / 6$ & $17 \mathrm{~J}$ & $17 J$ & $22 \cdot E U 36-203$ & 17 & 0 & NA & 0 \\
\hline Benzene & $1 / 6$ & 640 & 640 & Z2-EU36-208 & 640 & 0 & 0 & 0 \\
\hline Butylbenzene & $2 / 6$ & 22 & 2,900 & 27-EU36-208 & 1,461 & 0 & $N A$ & 0 \\
\hline Cumente & $2 / 6$ & 15 & 3,000 & 22-EU36-20B & 1,508 & 0 & NA & 0 \\
\hline Ethylbenzente & $2 / 6$ & II & 20.000 & $22-E \cup 36-208$ & 10,006 & 0 & $\mathrm{NA}$ & 0 \\
\hline$M+P$ Xylens & $2 / 6$ & 2. \lfloor] & 65,000 & $22 \cdot E U 36-208$ & 32,501 & 0 & $N A$ & $\mathbf{I}$ \\
\hline Propylbenzene & 26 & 25 & 6,500 & Z2-EЏ $36-208$ & 3,263 & 0 & NA & 0 \\
\hline Toluene & $1 / 6$ & $4,400 \mathrm{~J}$ & $4,400 \mathrm{~J}$ & Z2.EU36.208 & 4,400 & [] & 0 & 0 \\
\hline $\begin{array}{l}\text { EU = exposure umit } \\
\text { GWW a groumdhaler } \\
\text { lnd = industrial } \\
\text { J = analyte was identified ano } \\
\text { PRG = prelininary remediati }\end{array}$ & $\begin{array}{l}\text { result is app } \\
\text { on gosl }\end{array}$ & ximare cone & ntration & $\begin{array}{l}\text { Res = residenijal } \\
\text { RL = remodialion lev } \\
\text { SL = scroening leved } \\
S W=\text { soil unit } \\
V O C=\text { volatile mogr }\end{array}$ & corrpoumd & & & \\
\hline
\end{tabular}

K-1501-J Class $2 \mathrm{SU}$ : There are two DVS systematic grtid sample locations and one DVS biased sample location in the K-150I-J Class 2 SU (Sect. 2.2.2). Analytical results from this Class 2 SU also serve to characterize the K-1503 Neutralization Pit FFA Site. Analytical results from the three sample locations summarized below show one metal and several tadionsclide ind PRG exceedances, metal and radionuclide Bkg exceedances, and detections of DRO, GRO, and PCBs.

EU Z2-36 K-1501-J CLASS 2 SU METALS WTTH BACKGROUND, PRG, GW SL ANDNOR RL EXCEEDANCES (mojkg) $0<10 \mathrm{ft}$

\begin{tabular}{|c|c|c|c|c|c|c|c|c|c|c|c|}
\hline \multirow[b]{2}{*}{ Antlyte } & \multirow[b]{2}{*}{$\begin{array}{c}\text { Detect } \\
\text { Irequency }\end{array}$} & \multirow[b]{2}{*}{$\begin{array}{c}\text { Mlaimnm } \\
\text { detect }\end{array}$} & \multirow[b]{2}{*}{$\begin{array}{c}\text { Mexdminm } \\
\text { Atteci }\end{array}$} & \multirow{2}{*}{$\begin{array}{c}\text { Locadion(s) of } \\
\text { maximun } \\
\text { detect }\end{array}$} & \multirow{2}{*}{$\begin{array}{l}\text { Averonge } \\
\text { deteeled } \\
\text { resulo }\end{array}$} & \multicolumn{6}{|c|}{ Number of anglyses excesedilyg criteria } \\
\hline & & & & & & $\begin{array}{c}\text { Max } \\
\text { RL }\end{array}$ & $\begin{array}{l}\text { Ave } \\
\text { RL }\end{array}$ & $\begin{array}{c}\text { lnd } \\
\text { PRG }\end{array}$ & Bdse & $\begin{array}{l}\text { GW } \\
\text { SL }\end{array}$ & $\begin{array}{l}\text { Res } \\
\text { PRG }\end{array}$ \\
\hline Alumitrum & $2 / 2$ & 12,000 & 36,000 & Z2-EU36-211 & 14,000 & NA & $\mathrm{NA}$ & 0 & 0 & NA & 2 \\
\hline Arsenic & $2 / 2$ & 9.7 & 27 & $22-E U 36-210$ & 18.4 & 0 & 0 & $\mathbf{1}$ & l & 0 & 2 \\
\hline Cadmìm & $\underline{2} / 2$ & 0.21 & 0.52 & Z2.-Eบ36-210 & 0.365 & NA & NA & 0 & $\mathrm{l}$ & NA & 0 \\
\hline Calcium & $2 / 2$ & 8,700 & ID, DOND & 22-EU36-211 & 9,350 & NA & $\mathrm{NA}$ & $\mathrm{NA}$ & 2 & NA & $\mathrm{NA}$ \\
\hline Chromiuth & $2 / 2$ & 25 & $33 \mathrm{I}$ & Z2-EU36-211 & 29 & NA & $\mathrm{NA}$ & 0 & 0 & 0 & 2 \\
\hline Copper & $2 n$ & 32 & 34 & Z2-EU36-230 & 33 & NA & NA & 0 & 2 & $\mathrm{NA}$ & 0 \\
\hline Iron & $2 / 2$ & 34,000 & 37,000 & $Z 3-E U 36-211$ & 35,500 & $\mathrm{NA}$ & NA & 0 & 0 & $N A$ & 2 \\
\hline Lead & $2 / 2$ & 23 & 66 & $22-E U 36-210$ & 44.5 & $\mathrm{NA}$ & $\mathrm{NA}$ & 0 & 1 & 0 & 0 \\
\hline
\end{tabular}


EU Z2-36 K-1501-J CLASS 2 SU METALS WTTH BACKGROUND,

PRG, GW Sh, AND/OR RL EXCEEDANCES (mikg) (0-10 ft (cont.)

\begin{tabular}{|c|c|c|c|c|c|c|c|c|c|c|c|}
\hline \multirow[b]{2}{*}{ Analyte } & \multirow[b]{2}{*}{$\begin{array}{l}\text { Detect } \\
\text { Trequency }\end{array}$} & \multirow[b]{2}{*}{$\begin{array}{c}\text { Minimaum } \\
\text { detest }\end{array}$} & \multirow[b]{2}{*}{$\begin{array}{l}\text { Maxinum } \\
\text { detect }\end{array}$} & \multirow{2}{*}{$\begin{array}{c}\text { Lacation(s) of } \\
\text { maximum } \\
\text { detest }\end{array}$} & \multirow{2}{*}{$\begin{array}{l}\text { Average } \\
\text { delecied } \\
\text { result }\end{array}$} & \multicolumn{6}{|c|}{ Nember of analyneg excearieg criteris } \\
\hline & & & & & & $\begin{array}{l}\text { Nax } \\
\text { RI }\end{array}$ & $\begin{array}{l}\text { Avg } \\
\text { RL }\end{array}$ & $\begin{array}{l}\text { Ind } \\
\text { PRG }\end{array}$ & Bkg & $\begin{array}{l}\text { GW } \\
\text { SL }\end{array}$ & $\begin{array}{l}\text { Res } \\
\text { PRG }\end{array}$ \\
\hline Magnesium & $2 / 2$ & $1, \overline{500}$ & $9,400 \mathrm{~J}$ & Z2-EU36-211 & 5,450 & NA & $\mathrm{NA}$ & NA & $\mathrm{l}$ & $\mathrm{Na}$ & NA \\
\hline Manganote & 22 & T3भT & 1,100 & $22-E \bigcup 36-210$ & 915 & NA & NA & 0 & 0 & NA & $z$ \\
\hline Mescury & $2 / 2$ & 0036 & 017 & ZZ-EU36-210 & 0103 & th & 0 & 0 & $\mathbf{3}$ & $\mathrm{NA}$ & 0 \\
\hline N1ckel & $2 / 2$ & 21 & 44J & Z2-EU36-21l & 325 & NA & NA & 0 & $\mathbf{a}$ & NA & 0 \\
\hline Salemụm & $1 / 2$ & 16 & 16 & 27-EU36-2ll & 16 & NA & NA & 0 & 3 & NA & 0 \\
\hline Vanadrum & $2 n$ & 37 & 56 & Z2-EU36-210 & 46.5 & NA & $\mathrm{NA}$ & 1) & 0 & $\mathrm{NA}$ & 2 \\
\hline Znet & $2 / 2$ & 89 & $140 \mathrm{~J}$ & $22-E \backslash 36-211$ & 115 & $\mathrm{NA}$ & $N A$ & 0 & I & $\mathrm{NA}$ & 0 \\
\hline \multicolumn{5}{|c|}{ 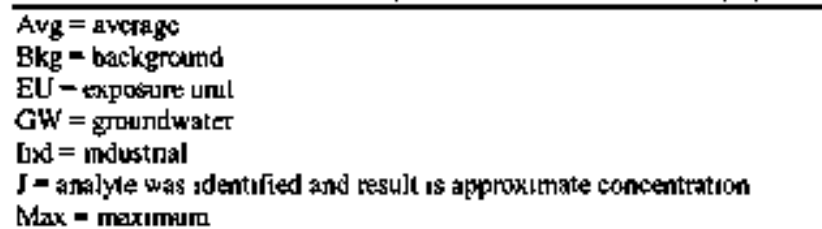 } & \multicolumn{7}{|c|}{ 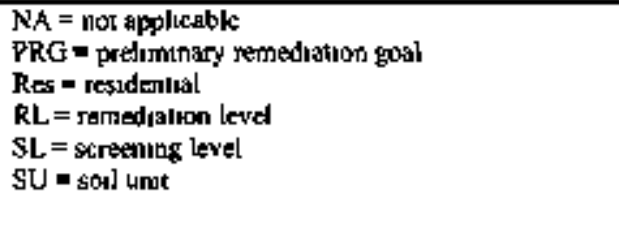 } \\
\hline
\end{tabular}

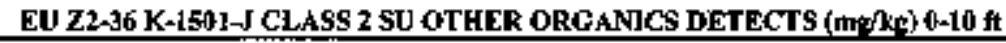

\begin{tabular}{|c|c|c|c|c|c|}
\hline Antbyte & $\begin{array}{c}\text { Detect } \\
\text { frequency }\end{array}$ & $\begin{array}{c}\text { Metimure } \\
\text { detect }\end{array}$ & $\begin{array}{l}\text { Maxlinim } \\
\text { datect }\end{array}$ & $\begin{array}{c}\text { Locatien(g) of } \\
\text { ansimum } \\
\text { detect }\end{array}$ & $\begin{array}{l}\text { Average } \\
\text { detected } \\
\text { reault }\end{array}$ \\
\hline Dycscl Range Drgenicg & $\mathbf{I} / \mathrm{l}$ & 521 & $52 J$ & $22-E[336-230$ & 52 \\
\hline Gasolins Ramge Organcs & /ll & $046 \mathrm{~J}$ & $046 \mathrm{~J}$ & 22-EU36.210 & 0.46 \\
\hline
\end{tabular}

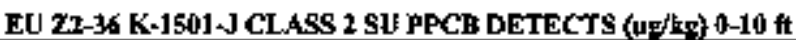

\begin{tabular}{|c|c|c|c|c|c|c|c|c|c|}
\hline \multirow[b]{2}{*}{ Analyte } & \multirow[b]{2}{*}{$\begin{array}{l}\text { Detert } \\
\text { iregouerey }\end{array}$} & \multirow[b]{2}{*}{$\begin{array}{l}\text { Minimam } \\
\text { detect }\end{array}$} & \multirow[b]{2}{*}{$\begin{array}{l}\text { Marimum } \\
\text { detect }\end{array}$} & \multirow{2}{*}{$\begin{array}{l}\text { Lacution(c) of } \\
\text { maximmm } \\
\text { detect }\end{array}$} & \multirow{2}{*}{$\begin{array}{l}\text { Averibet } \\
\text { decterted } \\
\text { ressuly }\end{array}$} & \multicolumn{4}{|c|}{$\begin{array}{l}\text { Number of analyses } \\
\text { excestit neriteris }\end{array}$} \\
\hline & & & & & & $\begin{array}{l}\text { Max } \\
\text { RL }\end{array}$ & $\begin{array}{l}\text { Avr } \\
\text { RL }\end{array}$ & $\begin{array}{l}\text { lnd } \\
\text { PRG }\end{array}$ & $\begin{array}{l}\text { Rog } \\
\text { PRC }\end{array}$ \\
\hline РCB-1260 & $1 / 2$ & $17 \mathrm{~J}$ & $17 \mathrm{~J}$ & Z2-EL:36-210 & 17 & 0 & 0 & 0 & 0 \\
\hline Pobychlonnialed buphenyl & $1 / 2$ & $17 \mathrm{~J}$ & $17 J$ & $\mathrm{Z2}-\mathrm{El} ; 36-210$ & 17 & 0 & 0 & 0 & 0 \\
\hline 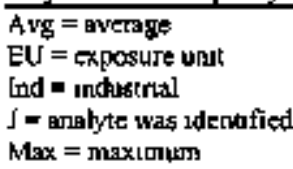 & d result is & 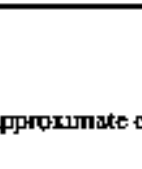 & & \multicolumn{6}{|c|}{ 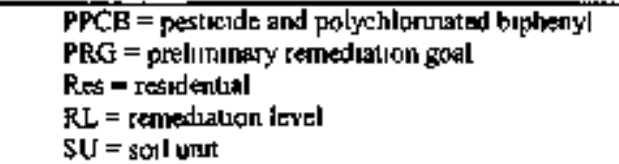 } \\
\hline
\end{tabular}

EU Z2-36 K-1501-J CLASS 2 \$U RADLONDCLLDES WTTH BACKGROUND, PRG, ANDIOR RL EXCEED $A N C E S$ (1) C $/ g) 0-10$ it

\begin{tabular}{|c|c|c|c|c|c|c|c|c|c|c|c|}
\hline \multirow[b]{2}{*}{ Alpabyta } & \multirow[b]{2}{*}{$\begin{array}{c}\text { Doxest } \\
\text { frequency }\end{array}$} & \multirow[b]{2}{*}{$\begin{array}{c}\text { Minimnm } \\
\text { detect }\end{array}$} & \multirow[b]{2}{*}{$\begin{array}{c}\text { Moximum } \\
\text { dotext }\end{array}$} & \multirow[b]{2}{*}{$\begin{array}{l}\text { Lactatien(s) of } \\
\text { msximn detect }\end{array}$} & \multirow{2}{*}{$\begin{array}{c}\text { Average } \\
\text { detected } \\
\text { result }\end{array}$} & \multicolumn{6}{|c|}{ Number of anglyses exeneding crituin } \\
\hline & & & & & & $\begin{array}{c}\text { Mnx } \\
\text { RL }\end{array}$ & $\begin{array}{l}\text { Avs } \\
\text { Bll }\end{array}$ & $\begin{array}{c}\text { Ind } \\
\text { PRG }\end{array}$ & Bkgg. & $\begin{array}{l}\text { GW } \\
\text { SL }\end{array}$ & $\begin{array}{l}\text { Reg } \\
\text { PRG }\end{array}$ \\
\hline Porassium-40 & I/1 & 937 & 937 & Z2-EU36-210 & 937 & $\mathrm{NA}$ & $\mathrm{NA}$ & l & 0 & NA & $\mathbf{I}$ \\
\hline Thonum-22B & $\mathbf{y} / 1$ & 183 & 183 & 22-EU36-210 & 183 & $\mathrm{NA}$ & NA & l & 0 & $\mathrm{NA}$ & $\mathbf{I}$ \\
\hline Thenuma-230 & $3 / 1$ & 215 & 215 & Z2-EL336-210 & 215 & $\mathrm{NA}$ & NA & 0 & I & NA & 0 \\
\hline Thomum-232 & $\mathbf{I} / 1$ & 176 & 176 & Z2.EU36-210 & 176 & $\mathrm{NA}$ & $\mathrm{NA}$ & 1 & 1) & NA & $\mathbf{I}$ \\
\hline Uramurr-238 & $\mathbf{1} / \mathbf{1}$ & 264 & 264 & 22-EU36-210 & 264 & 0 & 0 & 0 & $\mathbf{I}$ & 0 & I \\
\hline 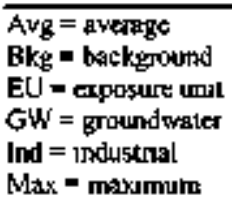 & & $\begin{array}{l}\text { NA = nod ap } \\
\text { PRG = prel| } \\
\text { Res = reskde } \\
\text { RL = remed } \\
\text { SL = screen } \\
\text { SU - soll un }\end{array}$ & $\begin{array}{l}\text { plicable } \\
\text { thinary temer } \\
\text { alual } \\
\text { lation bevel } \\
\text { ing level } \\
\text { til }\end{array}$ & diation goal & & & & & & & \\
\hline
\end{tabular}

svOCs and VOCs were analyzed $\mathrm{m}$ two samples but were not detected. 
Storm Drains: Three storm drans were identufied for samplıng under DVS and two sample locatons were Identiffed at each storn drain (one sedimsent sample location from inside the storm dran and one soil sample location from outside the storm dran) (Sect. 22.3). Antyttcal results summarized below show PCB-1254 and polychlorinated buphenyl Avg RL exceedances in the sediment sample from the K-l40l stom drain; metal, PCB, and radıonuclide Ind PRG exceedances; metal and radionuclide Bkg exceedances, and PCB, SVOC, and VOC detections.

EU Z2-36 STORM DRAINS METALS WITH BACKGROUND, PRG, GW SL, AND/OR RL. EXCEEDANCES (mg/kg) 0-10 ft

\begin{tabular}{|c|c|c|c|c|c|c|c|c|c|c|c|}
\hline \multirow[b]{2}{*}{ Antylyte } & \multirow[b]{2}{*}{$\begin{array}{c}\text { Detect } \\
\text { frequenky }\end{array}$} & \multirow[b]{2}{*}{$\begin{array}{c}\text { Minimum } \\
\text { detect }\end{array}$} & \multirow[b]{2}{*}{$\begin{array}{c}\text { Moximum } \\
\text { detect }\end{array}$} & \multirow{2}{*}{$\begin{array}{c}\text { Loctition(s) of } \\
\text { maximure } \\
\text { defect }\end{array}$} & \multirow{2}{*}{$\begin{array}{l}\text { Avetige } \\
\text { detected } \\
\text { rexult }\end{array}$} & \multicolumn{6}{|c|}{ Number of antlyses excopding critteria } \\
\hline & & & & & & $\begin{array}{c}\text { MLax } \\
\text { RL }\end{array}$ & $\begin{array}{l}\text { Ave } \\
\text { RL }\end{array}$ & $\begin{array}{l}\text { Ind } \\
\text { PRG }\end{array}$ & Bkg & $\begin{array}{l}\text { GW } \\
\text { SL }\end{array}$ & $\begin{array}{c}\text { Res } \\
\text { PRG }\end{array}$ \\
\hline Alumunum & $6 / 6$ & 1,400 & 16,000 & 22-EU36B-302 & 9,567 & $\mathrm{NA}$ & NA & 0 & 0 & NA & 4 \\
\hline Antudraly & $6 / 6$ & 0028 & 2 & Z2)-E】36B-303 & 05 & NA & NA & 0 & ] & 0 & 0 \\
\hline Arsenic & $64(5$ & 24 & 37 & Z2-EU36B-303 & 107 & 0 & 0 & $\mathbf{I}$ & 1 & 0 & 6 \\
\hline Barmum & $6 / 6$ & 7 & 260 & $\mathrm{Z2}-\mathrm{EL} 36 \mathrm{~B}-303$ & 130 & $N_{A}$ & $\mathrm{NA}$ & 0 & 2 & 0 & 0 \\
\hline Cadminm & 66 & 01 & 19 & 20.EU36B-301 & os & NA & $N_{A}$ & 0 & 4 & $\mathrm{NA}$ & 0 \\
\hline Calcıum & $6 / 6$ & 3,600 & 210,000 & Z2-EU36B-301 & 79,783 & NA & $\mathrm{NA}$ & NA & 6 & $\mathrm{NA}$ & $\mathrm{NA}$ \\
\hline Chrom & $6 / 6$ & 26 & 160 & $22-E U 36 \mathrm{~B}-301$ & 653 & $\mathrm{NA}$ & $N_{A}$ & 0 & 2 & 0 & 6 \\
\hline Copper & 646 & 28 & 110 & 22-EU36E-301 & 628 & $\mathrm{NA}$ & $\mathrm{NA}$ & 0 & 6 & NA & 0 \\
\hline Iron & $6 / 6$ & 17,000 & 140,000 & Z2-EU36B-303 & 51,167 & $N_{A}$ & $\mathrm{NA}$ & $\mathbf{I}$ & 1 & NA & 6 \\
\hline Lead & $6 / 6$ & 11 & 340 & Z2-El\}36B-301 & 787 & NA & NA & 0 & 2 & 0 & 0 \\
\hline Magnessum & 616 & 3,600 & 65,000 & Z2-EU36B-30I & 24,167 & $\mathrm{NA}_{\mathrm{A}}$ & $\mathrm{NA}$ & $\mathrm{NA}$ & 6 & $N A$ & NA \\
\hline Manganese & $6 / 6$ & 180 & 4,200 & Z2-E\36B-303 & 1,585 & $\mathrm{NA}$ & $\mathrm{NA}$ & 0 & $\mathrm{l}$ & NA & 6 \\
\hline Metcury & $5 / 6$ & 0025 & 038 & Z2-EU36B-301 & 01 & 0 & 0 & 0 & I & $\mathrm{NA}$ & 0 \\
\hline Nekel & 616 & 17 & 210 & Z2-EL36E-303 & 837 & NA & $\mathrm{NA}$ & 0 & 5 & NA & I \\
\hline Silver & $3 / 6$ & 021 & 065 & Z2-EU\}36B-301 & 04 & NA & NA & 0 & l & NA & 0 \\
\hline Utanumm & $6 / 6$ & 068 & 47 & Z2-EU36B-308 & 17 & NA & NA & 0 & NA & $\mathrm{NA}$ & 2 \\
\hline Vanadjucr & $6 / 6$ & 66 & 31 & $22-E \coprod 36 \mathrm{~B}-302$ & 213 & $\mathrm{NA}$ & $\mathrm{NA}$ & 0 & 0 & NA & 5 \\
\hline$Z_{\text {Ins }}$ & 646 & $\$ 2$ & 390 & 22-Eบ36B-301 & 143 & $N A$ & $\mathrm{NA}$ & 0 & 3 & $\mathrm{NA}$ & 0 \\
\hline \multicolumn{2}{|c|}{$\begin{array}{l}\text { Avg = average } \\
\text { Bkg = background } \\
\text { EU = exposure unt } \\
\text { GW = groundwater } \\
\text { Ird = Indusctial } \\
\text { Max = maximum }\end{array}$} & \multicolumn{3}{|c|}{ 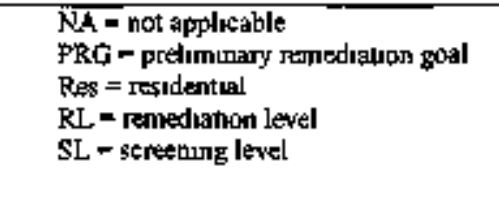 } & & & & & & & \\
\hline
\end{tabular}

EUJ Z2-36 STORM DRAIN\$ PPCB DETECTS (4t/kg) t-10 ft

\begin{tabular}{|c|c|c|c|c|c|c|c|c|c|}
\hline \multirow[b]{2}{*}{ Arabyte } & \multirow[b]{2}{*}{$\begin{array}{c}\text { Detoct } \\
\text { frequency }\end{array}$} & \multirow[b]{2}{*}{$\begin{array}{l}\text { Mtimimum } \\
\text { detect }\end{array}$} & \multirow[b]{2}{*}{$\begin{array}{l}\text { Maximann } \\
\text { detect }\end{array}$} & \multirow{2}{*}{$\begin{array}{l}\text { Locetion(s) of } \\
\text { mavinum } \\
\text { detect }\end{array}$} & \multirow{2}{*}{$\begin{array}{l}\text { Average } \\
\text { detected } \\
\text { result }\end{array}$} & \multicolumn{4}{|c|}{$\begin{array}{l}\text { Nimmber of inelysts } \\
\text { exceedine criterije }\end{array}$} \\
\hline & & & & & & $\begin{array}{c}\text { MAr } \\
\text { RL }\end{array}$ & $\begin{array}{l}\text { Ave } \\
\text { RL }\end{array}$ & $\begin{array}{l}\text { Ind } \\
\text { PRG }\end{array}$ & $\begin{array}{l}\text { Pex } \\
\text { PRG }\end{array}$ \\
\hline PCB-1254 & $3 / 6$ & 27 & $16,0 \infty 0$ & Z2-EU36B-30] & 5,373 & 0 & l & 1 & 1 \\
\hline PCE-1260 & $1 / 6$ & 18J & $18 J$ & 22-EU36B-303 & 18 & 0 & 0 & 0 & 0 \\
\hline Potychknnated biphenyl & $4 / 6$ & [\$] & 16,000 & 22-EU3(6B-30] & 4,035 & 0 & 1 & I & I \\
\hline 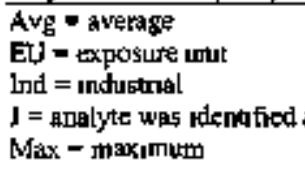 & A result is & 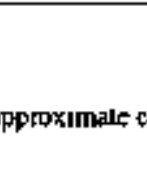 & . & \multicolumn{6}{|c|}{ 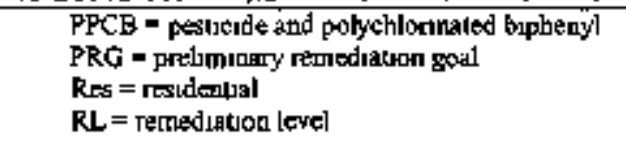 } \\
\hline
\end{tabular}


EU Z2-36 STORM DRAINS RADIONUCLLDES WTTH

BACKGROUND, PRG, ANDOR RL EXCEEDANCES (pCVg) 0-10 it

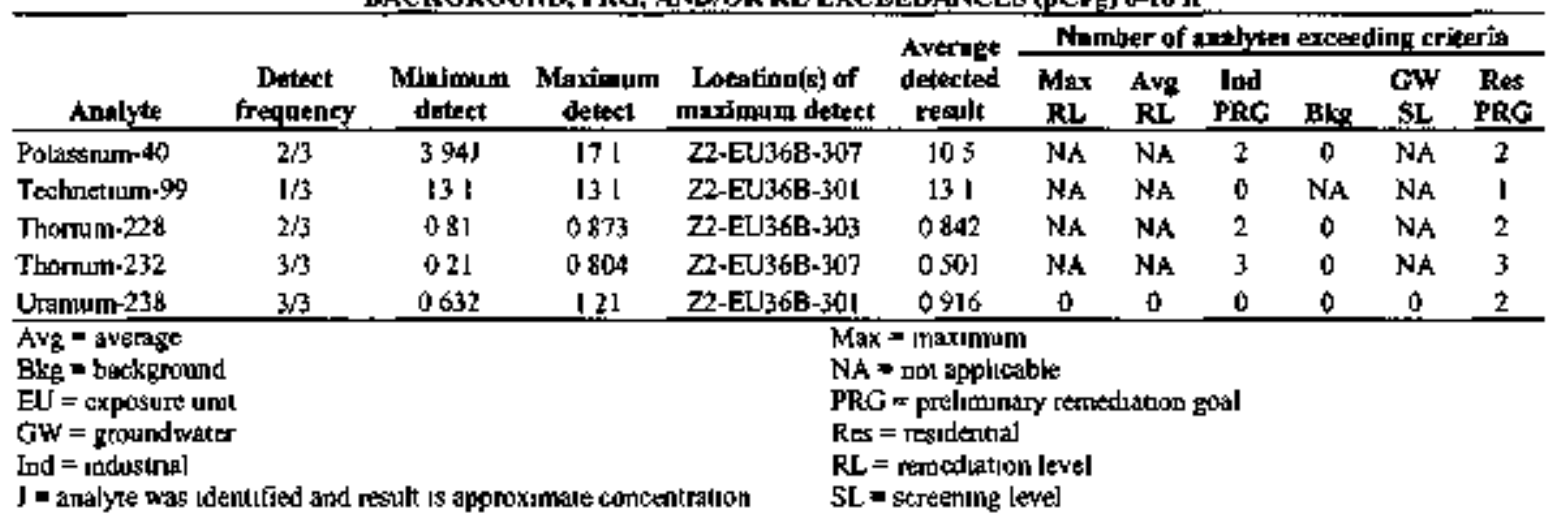

EU 22-36 STORM DRAINS SYOC DETECTS (ng/kg) 0-10 it

\begin{tabular}{|c|c|c|c|c|c|c|c|c|}
\hline \multirow[b]{2}{*}{ Antlyte } & \multirow[b]{2}{*}{$\begin{array}{c}\text { Detect } \\
\text { frocfuency }\end{array}$} & \multirow[b]{2}{*}{$\begin{array}{l}\text { Minimum } \\
\text { dotect }\end{array}$} & \multirow[b]{2}{*}{$\begin{array}{c}\text { Maximum } \\
\text { detect }\end{array}$} & \multirow[b]{2}{*}{$\begin{array}{l}\text { Locntiou(s) of } \\
\text { masimam detert }\end{array}$} & \multirow{2}{*}{$\begin{array}{l}\text { Average } \\
\text { detected } \\
\text { retult }\end{array}$} & \multicolumn{3}{|c|}{$\begin{array}{l}\text { Number of andych } \\
\text { excedting criteris }\end{array}$} \\
\hline & & & & & & $\begin{array}{l}\text { Ind } \\
\text { PRG }\end{array}$ & $\begin{array}{l}\text { GW } \\
\text { SL }\end{array}$ & $\begin{array}{l}\text { Res } \\
\text { PRG }\end{array}$ \\
\hline I-Methyhaphothakene & $1 / 3$ & $99 \mathrm{~J}$ & $99 \mathrm{~J}$ & Z2-EU36B-304 & 99 & NA & $\mathrm{NA}$ & $\mathrm{NA}$ \\
\hline 2-Mlethy|naphthakene & $2 / 6$ & $\lfloor 00\rfloor$ & $200 \mathrm{~J}$ & 22-EU36B-307 & 150 & 0 & $\mathrm{NA}$ & 0 \\
\hline Anthracente & $3 / 6$ & l IoJ & $390 \mathrm{~J}$ & Z2-EU36B-303 & 250 & 0 & NA & 0 \\
\hline Benzida)anthurecenc & $4 / 6$ & $360 \mathrm{~J}$ & $2,300 \mathrm{~J}$ & $22-E U 36 \mathrm{~B}-303$ & 930 & 0 & NA & $\mathbf{I}$ \\
\hline Benzo(a)pytetne & $4 / 6$ & $370 \mathrm{I}$ & $1,400 \mathrm{~J}$ & 22-EU36B.303 & 673 & 0 & NA & 4 \\
\hline Besszo(b)fluarsulhene & $4 / 6$ & 4901 & $1,000 \mathrm{~J}$ & Z2.EL36B-303 & 943 & 0 & $\mathrm{NA}$ & 2 \\
\hline Benzo(gh)penylene & $3 / 6$ & I60J & $1,300 \mathrm{~J}$ & Z2-EU36B-303 & 563 & 0 & NA & 0 \\
\hline Bunxo(k), lluoranthene & $4 / 6$ & $250 \mathrm{~J}$ & 1,2001 & $22-E U 36 B-303$ & 500 & 0 & NA & 마 \\
\hline Bıs 2 -calhylhexxyl)plthts]atc & $2^{\prime} 6$ & $300 \mathrm{~J}$ & $3,000 \mathrm{~J}$ & $22-E U 36 \mathrm{~B}-301$ & 1,650 & 0 & 0 & 0 \\
\hline Curbazole & $1 / 6$ & $440 \mathrm{~J}$ & $440 \mathrm{~J}$ & Z2-EU36B-303 & 440 & 0 & NA & 0 \\
\hline Chrysente & $4 / 6$ & $250 \mathrm{~J}$ & $1,000 \mathrm{~J}$ & 72 -EU36E-303 & 755 & 0 & NA & 0 \\
\hline Dibenz(a,h)anthracene & 1,6 & $390 \mathrm{~J}$ & $390 \mathrm{~J}$ & 22.EU36E-303 & 390 & 0 & $N A$ & $\mathbf{I}$ \\
\hline Furaranthene & $4 / 6$ & 810 & 5,000 & Z2-EU36B-3073 & 2,078 & 0 & NA & 0 \\
\hline Fluorene & $1 / 6$ & $280 J$ & $280 \mathrm{~J}$ & 22-EU36B-304 & 280 & 0 & NA & 0 \\
\hline mdeno $(1,2,3-\mathrm{cd}) \mathrm{py}$ тепе & $4 / 6$ & 1601 & $I, 1 \infty)$ & Z2-ELi36B-303 & 418 & 0 & NA & ] \\
\hline Phenamilhrene & $4 / 6$ & 3401 & 2,400 & 22-EU36B- 307 & 1,163 & 0 & NA & 0 \\
\hline Pyrente & $5 / 6$ & $400 \mathrm{~J}$ & $8,200 \mathrm{~J}$ & Z2.EU36B-303 & 2,326 & 0 & NA & 0 \\
\hline $\begin{array}{l}\text { EU = exposuce und } \\
\text { GW = groundwater } \\
\text { ind = jndusctnal } \\
\text { J * analyte Was idendıfied } \\
\text { NA = nod upplicable }\end{array}$ & & & & $\begin{array}{l}\text { PRG = prel } \\
\text { Res = reside } \\
\text { RL = remed } \\
\text { SL = scrent } \\
\$ V O C=5 \in\end{array}$ & 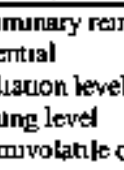 & liahe & & \\
\hline
\end{tabular}

EU 22-36 STORM DRAINS VOC DETECTS (ajkg) 0-10 f

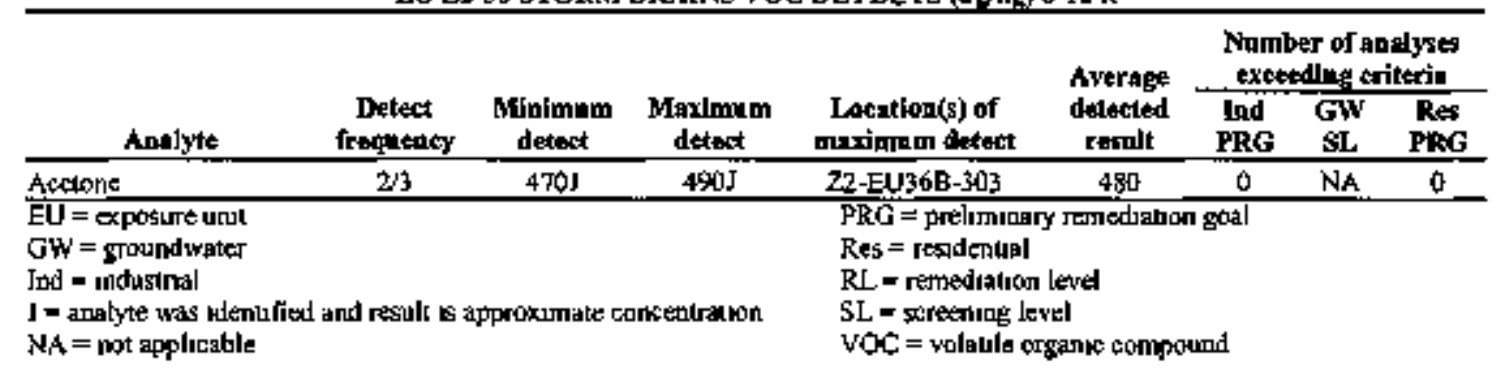

Coal Yards: There is one DVS biased sample location tn the K-IS01-N Coal Yard and the K-1501-S Coal Yard (Sect. 2.2.3). Each sample represents a four-pount composite sample. Analyucal results for the two sample locations summanzed below show metal Bkg exceedances and PCB and SVOC detectons. 
EU Z2-36 COAL YARDS METALS WITH BACKGROUND,

PRG, GW SL AND/OR RL EXCEEDANCES (molkot) 0-10 ft

\begin{tabular}{|c|c|c|c|c|c|c|c|c|c|c|c|}
\hline \multirow[b]{2}{*}{ Analyte } & \multirow[b]{2}{*}{$\begin{array}{l}\text { Detect } \\
\text { frequetery }\end{array}$} & \multirow[b]{2}{*}{$\underset{\text { deftect }}{\text { Mindmum }}$} & \multirow[b]{2}{*}{$\begin{array}{c}\text { Maximum } \\
\text { deloct }\end{array}$} & \multirow{2}{*}{$\begin{array}{c}\text { Location(c) of } \\
\text { maylmom } \\
\text { deteet }\end{array}$} & \multirow{2}{*}{$\begin{array}{l}\text { Average } \\
\text { detected } \\
r=1+4\end{array}$} & \multicolumn{6}{|c|}{ Number of andyges exceding criterla } \\
\hline & & & & & & $\begin{array}{c}\text { Max } \\
\text { R! }\end{array}$ & $\begin{array}{l}\text { AvE } \\
\text { RL }\end{array}$ & $\begin{array}{l}\text { Ind } \\
\text { PRQ }\end{array}$ & Bkp & $\begin{array}{l}\text { GW } \\
\text { SL }\end{array}$ & $\begin{array}{c}\text { Rea } \\
\text { PRG }\end{array}$ \\
\hline Ahymưum & $2 \sqrt{2}$ & 12,1000 & 16,000 & Z2-EU3\$B-306 & 14,000 & $\mathrm{NA}$ & NA & 0 & 0 & $\mathrm{NA}$ & 2 \\
\hline Assentc & $2 / 2$ & 41 & 89 & Z2-EU368-305 & 65 & 0 & 0 & 0 & 0 & 0 & 2 \\
\hline Cadmiun & $2 / 2$ & 022 & 024 & 22-EU36B-305 & 023 & NA & NA & 0 & 2 & NA & 0 \\
\hline Calçım & 22 & 15,000 & $22,0,00$ & $27-E U 36 \mathrm{~B}-306$ & 18,500 & NA & $\mathrm{NA}$ & NA & 2 & NA & NA \\
\hline Chrörulun & $2 / 2$ & 30 & 35 & 22-EU36B-306 & 325 & $N A$ & $\mathrm{NA}$ & 0 & 0 & 0 & 2 \\
\hline Copper & $2 / 2$ & 13 & 47 & Z2-EU36B-306 & 30 & NA & NA & 0 & I & $\mathrm{NA}$ & 0 \\
\hline Iron & $2 n$ & 28,000 & 38,0000 & 22-EU36B-306 & 33,000 & $N A$ & $\mathrm{NA}$ & 0 & 0 & NA & 2 \\
\hline Magnesium & $2 / 2$ & 3,700 & 17,000 & 72.EU $36 \mathrm{~B}-306$ & 12,350 & NA & NA & NA & 2 & $\mathrm{NA}$ & $\mathrm{NA}$ \\
\hline Manganese & $2 / 2$ & 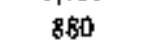 & 1,000 & Z2-EU36B-306 & 940 & NA & NA & 0 & 0 & $\mathrm{NA}$ & 2 \\
\hline Nekel & $2 / 2$ & 18 & 75 & Z2-EU36B-306 & 465 & NA & $\mathrm{NA}$ & 0 & I & $\mathrm{NA}$ & 0 \\
\hline Selennum & $1 / 2$ & 16 & 16 & $Z 2-E \bigcup 36 \mathrm{~B}-305$ & 16 & NA & $N_{A}$ & 0 & I & $\mathrm{NA}$ & 0 \\
\hline Uнаาиนm & $2 / 2$ & 12 & 23 & Z2-EU36B-306 & 175 & NA & NA & (1) & $\mathrm{NA}$ & NA & 1 \\
\hline Vactadum & $2 / 2$ & 26 & 29 & 22.EU36B-316 & 275 & $\mathrm{NA}$ & NA & Q & 0 & $\mathrm{NA}$ & 2 \\
\hline \multicolumn{2}{|c|}{$\begin{array}{l}\text { Avg = average } \\
\text { Bkg = brekground } \\
\text { EU - exposure unis } \\
\text { GW = groundwater } \\
\text { Ind = industnal } \\
\text { Mak = maximund }\end{array}$} & $\begin{array}{l}\text { NA } \\
\text { PRE } \\
\text { Res } \\
\text { RL } \\
\text { SL }=\end{array}$ & 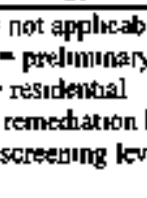 & $\begin{array}{l}\text { level } \\
\text { lemediation goal }\end{array}$ & & & & & & & \\
\hline
\end{tabular}

EU Z2-36 COAL YARDS PPCB DETECTS (uflkg) a-10 ft

\begin{tabular}{|c|c|c|c|c|c|c|c|c|c|}
\hline \multirow[b]{2}{*}{ Analyte } & \multirow[b]{2}{*}{$\begin{array}{l}\text { Detect } \\
\text { freguency }\end{array}$} & \multirow[b]{2}{*}{ Minimum } & \multirow[b]{2}{*}{$\begin{array}{l}\text { Maximum } \\
\text { deter }\end{array}$} & \multirow{2}{*}{$\begin{array}{c}\text { Location(s) of } \\
\text { manimal } \\
\text { detert }\end{array}$} & \multirow{2}{*}{$\begin{array}{l}\text { Avarage } \\
\text { detected } \\
\text { reaul }\end{array}$} & \multicolumn{4}{|c|}{$\begin{array}{l}\text { Neriber of andystes } \\
\text { excepeding criteria }\end{array}$} \\
\hline & & & & & & $\begin{array}{c}\text { Mar } \\
\text { RL }\end{array}$ & $\begin{array}{l}\text { Av8 } \\
\text { RL. }\end{array}$ & $\begin{array}{l}\text { Ind } \\
\text { PRG }\end{array}$ & $\begin{array}{l}\text { Res } \\
\text { PRC }\end{array}$ \\
\hline PCB-L254 & $1 / 2$ & 220 & 220 & Z2-EU\$36-306 & 220 & 0 & 0 & 0 & l \\
\hline Pohychlonnaled bupherisyl & $1 / 2$ & 220 & 220 & Z2.EU36B-306 & 220. & 6 & t? & 0 & 1 \\
\hline 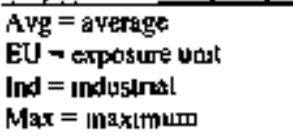 & $\begin{array}{l}\text { PP } \\
\text { PR } \\
\text { Re } \\
\text { RL }\end{array}$ & $\begin{array}{l}\text { CB = pesiscrd } \\
\text { O m prelimina } \\
=\text { ressudential } \\
=\text { renodiatior }\end{array}$ & $\begin{array}{l}\text { and polychl } \\
\text { oy remextiallo } \\
\text { n level }\end{array}$ & $\begin{array}{l}\text { oruhated brphenyl } \\
\text { in poidl }\end{array}$ & & & & & \\
\hline
\end{tabular}

EU 22-36 COAL YAROS SVOC DETECTS (u/ $/ \mathrm{kg})$ (0-10 it

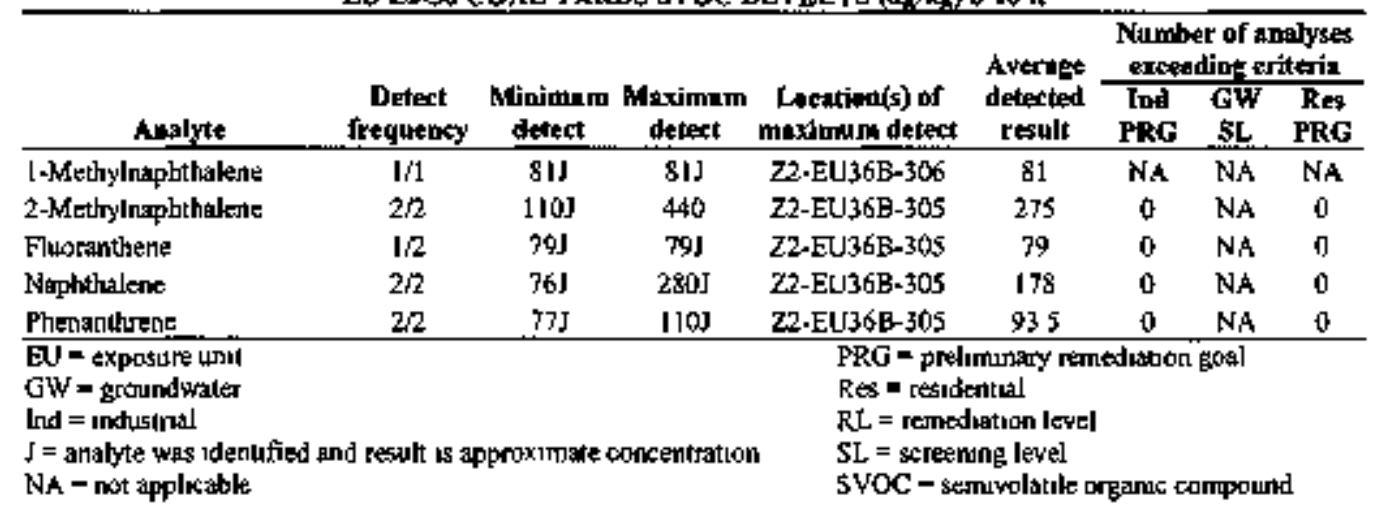

K-1501 Sump: Sodment from the surnp located east of the K-1501 Steam Plant was sarnpled as part of DVS characterzation pnor to a remedial action beung conducted (Sect 223 ) Analytical results from the sump sediment sample summarized below show one metal and several radionuclide and SVOC Ind PRG exceedances, metal and radionuclide $\mathrm{Bkg}$ exceedances, and DRO and SVOC detections 
EU Z2-36 K-150] SUMP MET ALS WITH BACKCROUND, PAG GW SL, ANDJOR RL EXCEEDANCES (mR/kg) 0-IO it

\begin{tabular}{|c|c|c|c|c|c|c|c|c|c|c|c|}
\hline \multirow[b]{2}{*}{ Anplyte } & \multirow[b]{2}{*}{$\begin{array}{c}\text { Detect } \\
\text { frequency }\end{array}$} & \multirow[b]{2}{*}{$\underset{\text { detract }}{\text { Minlimun }}$} & \multirow[b]{2}{*}{$\begin{array}{c}\text { Meximan } \\
\text { destect }\end{array}$} & \multirow{2}{*}{$\begin{array}{c}\text { Location(s) } \& f \\
\text { maxilioun } \\
\text { detext }\end{array}$} & \multirow{2}{*}{$\begin{array}{l}\text { Average } \\
\text { detected } \\
\text { reinlt }\end{array}$} & \multicolumn{6}{|c|}{ Nomber of analyses axceoding criteria } \\
\hline & & & & & & $\begin{array}{l}\text { Max } \\
\text { Rl }\end{array}$ & $\begin{array}{l}\text { Ave } \\
\text { AL }\end{array}$ & $\begin{array}{l}\text { lod } \\
\text { PRG }\end{array}$ & elkg & $\begin{array}{l}\text { GW } \\
\text { SL }\end{array}$ & $\begin{array}{l}\text { Ress } \\
\text { PAG }\end{array}$ \\
\hline Animony & $1 / 1$ & $2.4 \mathrm{~J}$ & $2.4 \mathrm{~J}$ & $22-E U 368-310$ & 2.4 & NA & $N A$ & 0 & 1 & 0 & 0 \\
\hline Așenic & $|/|$ & 31 & 31 & 22-EU36B-310 & 31 & 0 & 0 & $\mathbf{I}$ & I & 0 & I \\
\hline Barium & $1 / I$ & 140 & 140 & Z7-EU36B-310 & 140 & NA & $N_{A}$ & 0 & 1 & 0 & 0 \\
\hline Cadmium & $\mathbf{I} / \mathbf{I}$ & l.2J & 1.21 & Z2-EU36B-310 & 1.2 & NA & $\mathrm{NA}$ & 0 & 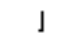 & NA & 0 \\
\hline Calcium & $1 / \mathbf{I}$ & 150,000 & 150,000 & Z2-EU36B-310 & 150,000 & NA & $\mathrm{NA}$ & $\mathrm{NA}$ & l & NA & NA \\
\hline Chromiu|r & $1 / 1$ & $23 \mathrm{~J}$ & 23J & 27-Eย $36 \mathrm{~B}-310$ & 23 & NA & $N_{A}$ & 0 & 0 & 0 & 1 \\
\hline Copper & $|/|$ & $110 \mathrm{~J}$ & $110 \mathrm{~J}$ & 22.EU36B-310 & 110 & NA & $\mathrm{NA}$ & 0 & l & NA & 0 \\
\hline [ron & ओ & $27,00(x)$ & $27,000 \mathrm{~J}$ & Z7-EU36E-310 & 27,000 & NA & $\mathrm{NA}_{\mathrm{A}}$ & 0 & 0 & $\mathbf{N A}_{\mathrm{A}}$ & 1 \\
\hline Lead & $1 / 1$ & $49 \mathrm{~J}$ & 49J & 22-EU36B-310 & 49 & NA & NA & 0 & $\mathrm{l}$ & 0 & 0 \\
\hline Magnesinm & $1 / 1$ & $15,000 \mathrm{~J}$ & 15,0010 & 27 -EU36B-310 & 15,000 & $N A$ & NA & NA & $\mathrm{l}$ & NA & $N_{A}$ \\
\hline Manganese & $1 / 1$ & 270, & $270 \mathrm{~J}$ & Z2-ELU36B-310 & $2 \pi 0$ & NA & $\mathrm{NA}$ & 0 & 0 & $N A$ & 1 \\
\hline Merxury & $|/|$ & $0.28 \mathrm{~J}$ & $0.28 \mathrm{~J}$ & Z2-EU36B-310 & 028 & 0 & 0 & 0 & I & NA & 0 \\
\hline Ni̇ckel & $1 / 1$ & $32 \mathrm{~J}$ & 325 & Z2-EU36B-310 & 32 & $N A$ & NA & 0 & l & $N_{A}$ & 0 \\
\hline Selentium & $\mathbf{I} / 1$ & 3 & 3 & Z2-EU36B-310 & 3 & NA & $\mathrm{NA}$ & 0 & $\mathrm{l}$ & $\mathrm{NA}_{\mathrm{A}}$ & 0 \\
\hline Thellium & $1 / 1$ & 0.54 .1 & $0.54 \mathrm{~J}$ & 22-EU36B-310 & 0.54 & $N_{A}$ & $\mathrm{NA}$ & 0 & $\mathrm{l}$ & 0 & 1 \\
\hline Uranium & $1 / 1$ & 1.6 & 1.6 & 22-EU $36 \mathrm{~B}-310$ & 1.6 & $N_{A}$ & $\mathrm{NA}$ & 0 & NA & $\mathrm{N}_{\mathrm{A}}$ & I \\
\hline Vanadium & $|/|$ & 19 & 19 & Z2-EU36B-3]0 & 19 & $\mathrm{NA}$ & $\mathrm{NA}$ & 0 & 0 & $\mathrm{NA}$ & I \\
\hline$\underline{Z i n} \underline{F}_{-}$ & I/I & $22,[0]$ & $220 \mathrm{~J}$ & Z2-EU36E-310 & 220 & $N A$ & $\mathrm{NA}$ & 0 & 1 & $\mathrm{NA}$ & 0 \\
\hline \multicolumn{5}{|c|}{ 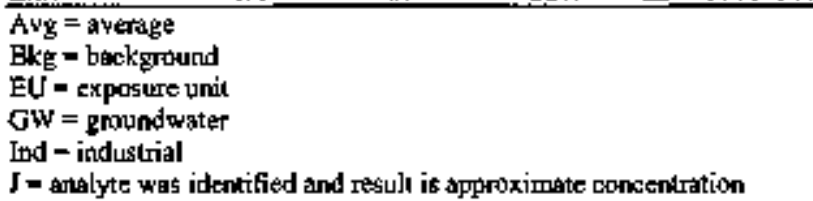 } & \multicolumn{7}{|c|}{$\begin{array}{l}\text { Max = maximulrs } \\
\text { NA = not applicable } \\
\text { PRG = prediminary remrediation goal } \\
\text { Res = residenlial } \\
\text { RL - remediation level } \\
\text { SL = screning level }\end{array}$} \\
\hline
\end{tabular}

EU Z3-36 K-1501 SUMP OTHER ORGANICS DETECIS (moke) 0-10 [t

\begin{tabular}{|c|c|c|c|c|c|}
\hline Anabyte & $\begin{array}{c}\text { Detect } \\
\text { frequeacy }\end{array}$ & $\begin{array}{l}\text { MinImmam } \\
\text { detect }\end{array}$ & $\begin{array}{c}\text { Maxinum } \\
\text { detect }\end{array}$ & $\begin{array}{l}\text { Location(s) of } \\
\text { madinim detect }\end{array}$ & $\begin{array}{l}\text { A werraghe } \\
\text { detected } \\
\text { result }\end{array}$ \\
\hline Diesel Range Organics & $|/|$ & $160 \mathrm{~J}$ & $160 \mathrm{~J}$ & Z2-EU36B-310 & 160 \\
\hline
\end{tabular}

PCBs were analyzed for but were not detected.

EU Z2-36 K-15AI \$UMP RADIONUCLDES WTTH

BACKGROUND, PRG, ANDJOR RL EXCEEDANCES (PCWR) 0-10 it

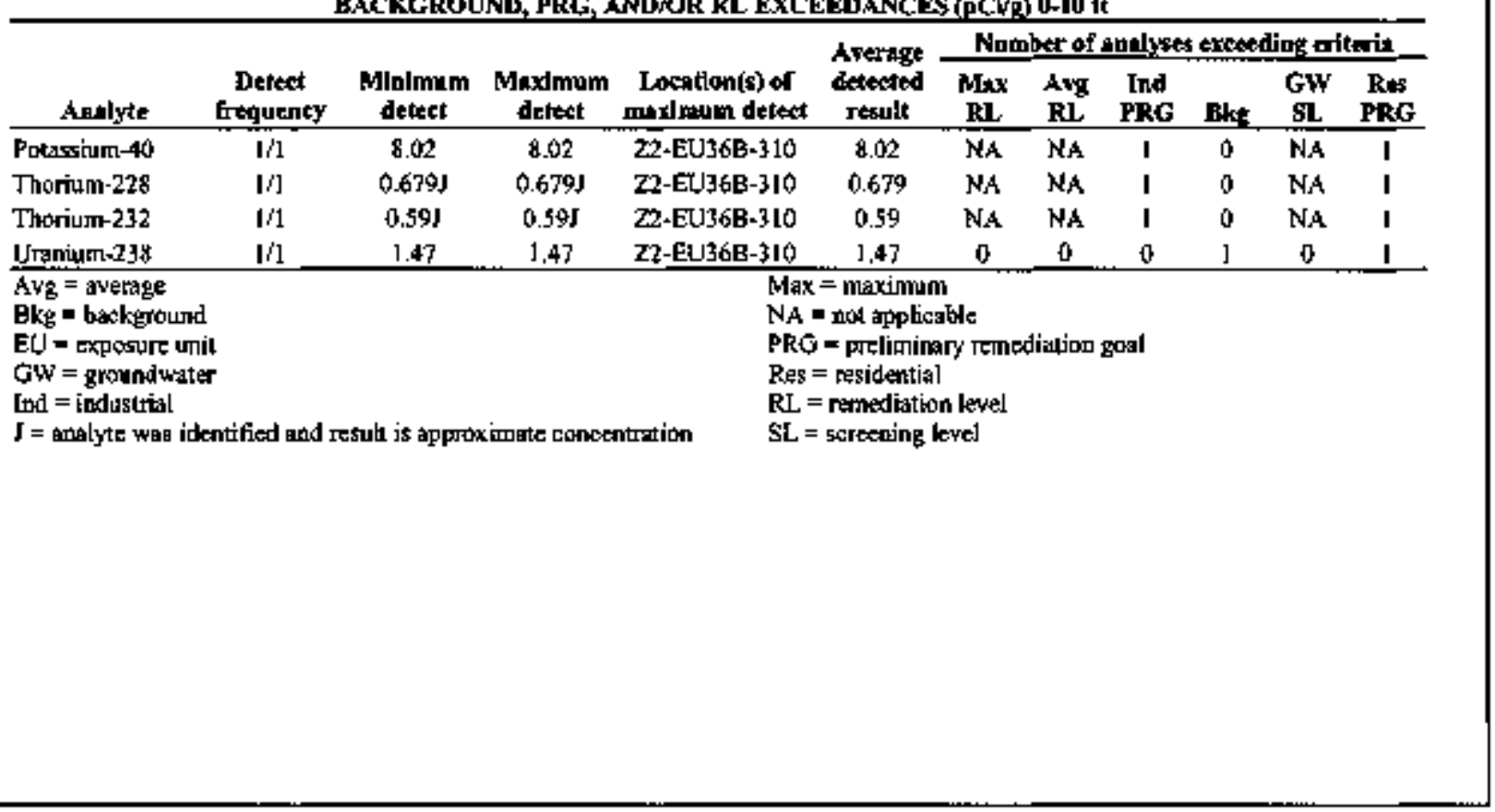




\begin{tabular}{|c|c|c|c|c|c|c|c|c|}
\hline \multirow[b]{2}{*}{ Analyte } & \multirow[b]{2}{*}{$\begin{array}{l}\text { Detect } \\
\text { froquency }\end{array}$} & \multirow[b]{2}{*}{$\begin{array}{l}\text { Mnlotmum } \\
\text { detext }\end{array}$} & \multirow[b]{2}{*}{$\begin{array}{l}\text { Mardenum } \\
\text { deted }\end{array}$} & \multirow[b]{2}{*}{$\begin{array}{l}\text { Loction(s) of } \\
\text { tuaximum datect }\end{array}$} & \multirow{2}{*}{$\begin{array}{c}\text { Average } \\
\text { detected } \\
\text { result }\end{array}$} & \multicolumn{3}{|c|}{$\begin{array}{l}\text { Nuriber of analyses } \\
\text { exceeting criteria }\end{array}$} \\
\hline & & & & & & $\begin{array}{l}\text { Ind } \\
\text { PRG }\end{array}$ & $\begin{array}{l}\text { GW } \\
\text { SL }\end{array}$ & $\begin{array}{l}\text { Res } \\
\text { PRG }\end{array}$ \\
\hline 2,4-Dimethylphental & $1 / 1$ & $94]$ & $94 J$ & 22-EU $36 \mathrm{~B}-310$ & 94 & 0 & $\mathrm{NA}$ & 0 \\
\hline 2-Methylnaphitagletre & $|/|$ & 4,400 & 4,400 & $22 \cdot E U 36 B \cdot 310$ & $4,4(0)$ & 0 & NA & 0 \\
\hline Acenaphuhene & $|i|$ & 10,000 & 10,000 & Z2.EU36B-310 & 10,0000 & 0 & $\mathrm{NA}$ & 0 \\
\hline Arthracens & $\mathbf{I} / \mathbf{I}$ & 28,000 & 28,000 & 20-Eు $368-310$ & 28,0000 & 0 & NA & 0 \\
\hline$B$ senz\{a\}anthractic & $|/|$ & $31,0 \infty 0$ & 31,000 & 22.EU36B-310 & 31,000 & $\mathbf{I}$ & $\mathrm{NA}$ & 1 \\
\hline Benzizo(a)pyrente & $|/|$ & 25,000 & 25,000 & Z2-EU36B- $\$ 10$ & 25,0000 & I & $\mathrm{NA}$ & 1 \\
\hline Beका7xofb\}fluoranthene & III & 34,000 & 34,000 & $27 \cdot E U 36 B \cdot 310$ & 34,0000 & $\mathbf{I}$ & NA & l \\
\hline Benzo(ghi)pesylente & $|/|$ & 5,200 & 5,200 & 22-EU36E-310 & 5,200 & 0 & Nh & 0 \\
\hline Berzotkjfivoranthene & III & 15,000 & 15,000 & 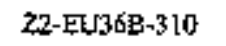 & 15,000 & 0 & $\mathrm{NA}$ & 1 \\
\hline Bis\{2-othy Thexyl)phthalate & $1 /]$ & 990 & 990 & 27.EU36-B-310 & 990 & 0 & 0 & 0 \\
\hline Carbazole & $1 / 1$ & 8,500 & 8,500 & 22-EU36E-310 & 8,500 & 0 & NA & 0 \\
\hline Dibenz(a,h)anthracene & 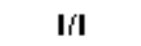 & 1,700 & 1,700 & $22-E U 36 \mathrm{E}-310$ & 1,700 & 0 & NA & $!$ \\
\hline Dibenzoflurar & líl & 7,200 & 7200 & 22-EU $36 \mathrm{~B}-310$ & 7,200 & 0 & $\mathrm{NA}$ & 0 \\
\hline Fluporgutheme & !II & 91,000 & $91,0 \infty 0$ & Z2-EU36B-310 & 91,000 & 0 & NA & 0 \\
\hline Fluorene & !II & 11,000 & 11,000 & Z2-EU36-B-310 & 11,000 & 0 & NA & 0 \\
\hline Indeno( $1,2,3-$-d)pyrene & !II & 10,000 & 10,000 & 22-EU36E-310 & 10,000 & 0 & NA & ! \\
\hline Naphthalene & $2 / 2$ & $140 J$ & 3,700 & Z2-EU36B-310 & 1,920 & 0 & NA & 0 \\
\hline Phedanthrene & $! !$ & 85,000 & 85,000 & Z2-EU36-3 30 & 85,000 & 0 & NA & $!$ \\
\hline Pyrence & $\mathbf{l} \mid \mathbf{I}$ & $+1,0,0$ & 71,000 & Z2-EU36E-310 & 71,000 & 0 & NA & 0 \\
\hline 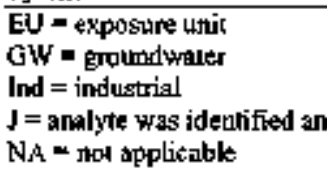 & result i & …… & 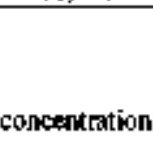 & $\begin{array}{l}\text { PRG - prefi } \\
\text { Res = reside } \\
\text { RL = remed } \\
\text { SL }=\text { screen } \\
\text { SVOC = }\end{array}$ & $\begin{array}{l}\text { mitiaty redm } \\
\text { mitial } \\
\text { iation leved } \\
\text { ing level } \\
\text { mivolatile on }\end{array}$ & diatio & $g \times 4]$ & \\
\hline
\end{tabular}

VOCs were analyzed for but were not detected.

Other Class 3 SU Historical Samplng: There are 14 historical sample locations in the EU Z2-36 Class 3 SU (Sect. 2.2.3) that are not associated with any of the preceding features of interest. Analytical results summarized below show radionuclide Ind PRG exceedances, metal and radionuclide Bkg exceedances, and delections of PCBs, SVOCs, and VOCs.

EU Z2-36 OTHER HISTORICAL METALS WTTH BACKGROUND, PRG, GW SL, ANDOR FL EXCEEDANCES (ma/kg) 0-to ft

\begin{tabular}{|c|c|c|c|c|c|c|c|c|c|c|c|}
\hline \multirow[b]{2}{*}{ Antolytt } & \multirow[b]{2}{*}{$\begin{array}{c}\text { Detect } \\
\text { froquonty }\end{array}$} & \multirow[b]{2}{*}{$\underset{\text { Metett }}{\text { Mlnimium }}$} & \multirow[b]{2}{*}{$\begin{array}{c}\text { Maxineum } \\
\text { detuct }\end{array}$} & \multirow{2}{*}{$\begin{array}{c}\text { Location(s) of } \\
\text { maximum } \\
\text { detete }\end{array}$} & \multirow{2}{*}{$\begin{array}{l}\text { Average } \\
\text { detected } \\
\text { rebult }\end{array}$} & \multicolumn{6}{|c|}{ Number of englyses exceeding criteris } \\
\hline & & & & & & $\begin{array}{c}\text { MaI } \\
\text { RL }\end{array}$ & $\begin{array}{l}\text { Avg } \\
\text { RL }\end{array}$ & $\begin{array}{l}\text { Ind } \\
\text { PRG } \\
\end{array}$ & Blys & $\begin{array}{l}\text { GW } \\
\text { SL. }\end{array}$ & $\begin{array}{l}\text { Res } \\
\text { PRG }\end{array}$ \\
\hline Aluminum & $5 / 5$ & 6,430 & 19,200 & $\$ 01$ & 11,648 & NA & $\mathrm{NA}$ & 0 & 0 & NA & 3 \\
\hline Arsenic & $5 / 5$ & 4.19 & 13.8 & sol & 8.39 & 0 & 0 & 0 & 0 & 0 & 5 \\
\hline Barium & $5 / 5$ & 99.15 & 232J & 503 & 143 & NA & $N A$ & 0 & 2 & 0 & o \\
\hline Cadmium & $\$ / 5$ & 0.592 & 4.68 & $\$ 01$ & 1.59 & NA & NA & 0 & 5 & NA & $\mathbf{I}$ \\
\hline Calcium & $5 / 5$ & 1400 & 26,000 & 501 & 7360 & NA & $N A$ & $\mathrm{NA}$ & 2 & $N A$ & NA \\
\hline Chromiun & $5 / 5$ & $9.88 \mathrm{~J}$ & 40.6 & S01 & 21.4 & NA & NA & 0 & 0 & 0 & 2 \\
\hline Copper & $5 / 5$ & 63 & $32]$ & sol & 210 & NA & $\mathrm{NA}$ & 0 & 5 & NA & $\mathbf{I}$ \\
\hline Inon & $5 / 5$ & 9,690 & 36,700 & SOI & 18,418 & NA & NA & 0 & 0 & NA & 5 \\
\hline Lead & $5 / 5$ & $13.8 \mathrm{~J}$ & 185 & sol & 60.0 & NA & $N_{A}$ & 0 & 2 & 0 & 0 \\
\hline Magnestium & $5 / 5$ & 7811 & 6,420 & SOI & 2,377 & $\mathrm{NA}$ & $\mathrm{NA}$ & $\mathrm{NA}$ & l & $N A$ & $\mathrm{NA}$ \\
\hline Menganese & $5 / 5$ & 690 & 1,480 & $\$ 03$ & 1,007 & NA & NA & 0 & 0 & $\mathrm{NA}$ & $\$$ \\
\hline Mercury & $5 / 5$ & $0.065 \mathrm{~J}$ & I 98 & 501 & 0.488 & 0 & 0 & 0 & 2 & NA & 0 \\
\hline Nickel & $5 / 5$ & 121 & 613 & $\$ 01$ & 397 & $\mathrm{NA}$ & $\mathrm{NA}$ & 0 & 5 & NA & 4 \\
\hline Selctius & $2 / 5$ & $0.323 \mathrm{~J}$ & 1.99 & sol & 1.16 & $\mathrm{NA}$ & NA & 0 & I & NA & 0 \\
\hline
\end{tabular}


IU 22-36 OTHER HISTORACAL METALS WTTH BACKGROUND,

PRG, GW Sl, AND/OR RL EXCEEDANCES (mg/kg) 0-10 ft (cont.)

\begin{tabular}{|c|c|c|c|c|c|c|c|c|c|c|c|}
\hline \multirow[b]{2}{*}{ Arilyte } & \multirow[b]{2}{*}{$\begin{array}{c}\text { Detect } \\
\text { Irequency }\end{array}$} & \multirow[b]{2}{*}{$\begin{array}{c}\text { Múninum } \\
\text { defect }\end{array}$} & \multirow[b]{2}{*}{$\begin{array}{c}\text { Maximum } \\
\text { detect }\end{array}$} & \multirow{2}{*}{$\begin{array}{c}\text { Lacatian(s) of } \\
\text { maxl mumpl } \\
\text { detect }\end{array}$} & \multirow{2}{*}{$\begin{array}{l}\text { Averzge } \\
\text { detected } \\
\text { result }\end{array}$} & \multicolumn{6}{|c|}{ Number of ansystes exceeding criteria } \\
\hline & & & & & & $\begin{array}{c}\text { Max } \\
\text { RL }\end{array}$ & $\begin{array}{l}\text { Av? } \\
\text { RL }\end{array}$ & $\begin{array}{c}\text { Ind } \\
\text { PREG }\end{array}$ & Bke & $\begin{array}{l}\text { GW } \\
\text { SL }\end{array}$ & $\begin{array}{l}\text { Res } \\
\text { PRC }\end{array}$ \\
\hline Silver & $1 / 5$ & $0.819 \mathrm{~J}$ & 0.BI9J & 801 & 0.819 & NA & NA & 0 & l & NA & 0 \\
\hline Vanadium & $5 \sqrt{5}$ & $12,5\rfloor$ & 44.1 & SOI & 24,7 & NA & NA. & 0 & 0 & $\mathrm{NA}$ & 5 \\
\hline Zine & $5 / 5$ & 59.2 .5 & $320 \mathrm{~J}$ & Sol & 123 & NA & $N A$ & 0 & 2 & NA & 0 \\
\hline \multicolumn{5}{|c|}{$\begin{array}{l}\text { AYg }- \text { average } \\
\text { Bkg = hackground } \\
\text { EU = cxpossune unit } \\
\text { GW = groundwaler } \\
\text { Ind = johustrial } \\
\text { J = analyte was jdentified }\end{array}$} & \multicolumn{7}{|c|}{ 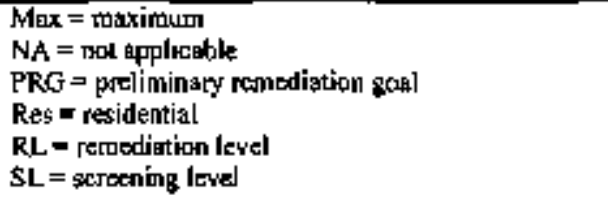 } \\
\hline
\end{tabular}

ED Z736 OTHER HLSTORICAL PPCB DETECTS (UT/L) (6-10 ft

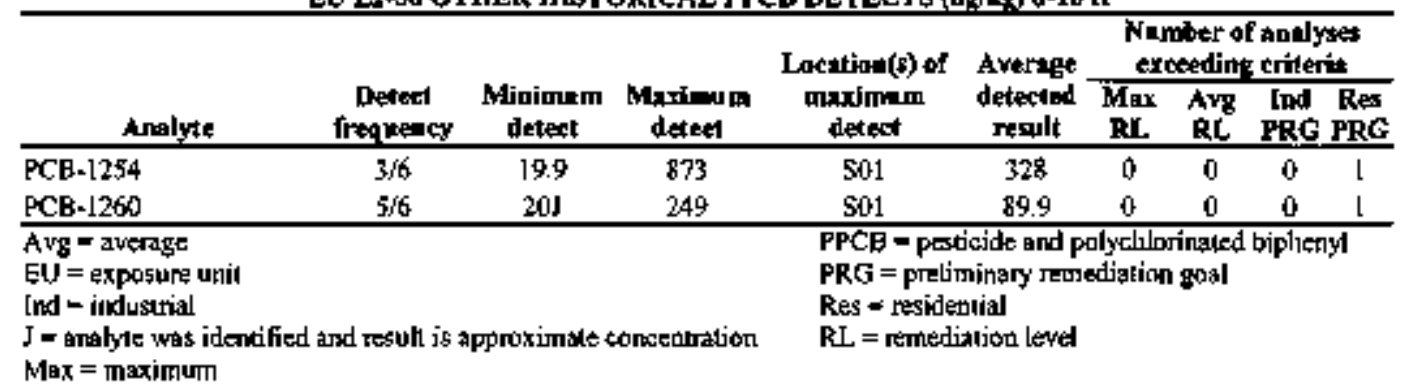

EU 22-36 OTHER HISTTORICAL RADIONUCLIDES WITH BACKGROUND, PRG ANDOR RL EXCEEDANCES (DCUK) 0-10 ft.

\begin{tabular}{|c|c|c|c|c|c|c|c|c|c|c|c|}
\hline \multirow[b]{2}{*}{ Analyta } & \multirow[b]{2}{*}{$\begin{array}{l}\text { Detect } \\
\text { frequenay }\end{array}$} & \multirow[b]{2}{*}{$\begin{array}{l}\text { Mindimimm } \\
\text { detefet }\end{array}$} & \multirow[b]{2}{*}{$\begin{array}{c}\text { Meximum } \\
\text { detect }\end{array}$} & \multirow[b]{2}{*}{$\begin{array}{l}\text { Locution(s) of } \\
\text { morimaum detect }\end{array}$} & \multirow{2}{*}{$\begin{array}{l}\text { Average } \\
\text { deteqtied } \\
\text { reșult }\end{array}$} & \multicolumn{6}{|c|}{ Number of andyser exceeding riteria } \\
\hline & & & & & & $\begin{array}{c}\text { Max } \\
\text { RL }\end{array}$ & $\begin{array}{l}\text { AvE } \\
\text { RL }\end{array}$ & $\begin{array}{l}\text { Ind } \\
\text { PRG }\end{array}$ & Fegr. & $\begin{array}{l}\text { GW } \\
\text { SL }\end{array}$ & $\begin{array}{l}\text { Res } \\
\text { PRE }\end{array}$ \\
\hline Cesium-137 & $12 / 15$ & 0.11 & $1.2 \mathrm{~d}$ & 501 & 0.550 & q & 0 & 2 & $\mathrm{NA}$ & NA & 12 \\
\hline Potassium 40 & $3 / 3$ & 27.6 & 29.9 & ETTP-RELOG & 29 & $N A$ & NA & 3 & 0 & NA & 3 \\
\hline Radium-276 & $3 / 3$ & 0.757 & ] & ETTP-RELOT & 0.891 & $\mathrm{NA}$ & $\mathrm{NA}$ & 3 & 0 & NA & 3 \\
\hline Tecluneajubs-99 & 1/Is & 2.94 & 2.94 & 501 & 2.94 & $N_{A}$ & NA & 0 & NA & $N_{A}$ & I \\
\hline Thorium-228 & IS/IS & $0.942 J$ & $1.81 \mathrm{~J}$ & 909 & 1.24 & NAB & $\mathrm{NA}$ & 15 & 0 & NA & 15 \\
\hline Thoriugn-230 & $15 / 15$ & 0.2281 & 1.945 & $\mathrm{SO}_{2}$ & 1.19 & $N A$ & $\mathrm{NA}$ & 0 & 9 & NA & 0 \\
\hline Thortium-232 & $15 / 15$ & $0.77 \mathrm{~J}$ & I.4J & 902 & 1.08 & $\mathrm{NA}$ & $\mathrm{NA}$ & 15 & 0 & $N_{A}$ & 15 \\
\hline Џг⿴піит-234 & $15 / 15$ & $0.276 \mathrm{~J}$ & 16.5 & Sol & 3.83 & 0 & 0 & 0 & $\mathrm{NA}$ & 0 & 6 \\
\hline
\end{tabular}

EU 22-36 OTHER HISTOFICAL RADIONUCLIDES WITH

BACKGROUND, PRG, AND/OR RL EXCEEDANCES (pCHg) 0-10 [t (cont.)

\begin{tabular}{|c|c|c|c|c|c|c|c|c|c|c|c|}
\hline \multirow[b]{2}{*}{ Anabyte } & \multirow[b]{2}{*}{$\begin{array}{c}\text { Dretect } \\
\text { frequency }\end{array}$} & \multirow[b]{2}{*}{$\begin{array}{l}\text { Minimimm } \\
\text { detepct }\end{array}$} & \multirow[b]{2}{*}{$\begin{array}{l}\text { Merimum } \\
\text { detect }\end{array}$} & \multirow[b]{2}{*}{$\begin{array}{l}\text { Lacutban(s) of } \\
\text { murimum detes }\end{array}$} & \multirow{2}{*}{$\begin{array}{c}\text { Average } \\
\text { detected } \\
\text { result }\end{array}$} & \multicolumn{6}{|c|}{ 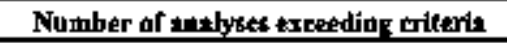 } \\
\hline & & & & & & $\begin{array}{l}\text { Mar } \\
\text { RL }\end{array}$ & Avy & $\begin{array}{l}\text { Ind } \\
\text { PRG }\end{array}$ & Bkg & $\begin{array}{l}\text { GW } \\
\text { SL }\end{array}$ & $\begin{array}{l}\text { Res } \\
\text { PRG }\end{array}$ \\
\hline 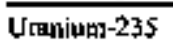 & $14 / 15$ & $0.0239 \mathrm{~J}$ & 0.932 & sot] & $0.23 \mathrm{~L}$ & 0 & 0 & $\theta$ & NA & 0 & 8 \\
\hline Uranium 238 & $15 / 15$ & $0.162 \mathrm{~J}$ & 7.03 & Sol & 1.99 & 0 & 0 & 0 & 10 & 0 & 12 \\
\hline 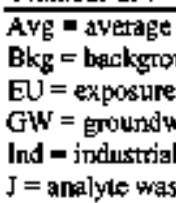 & ntified and & ult is appron & Thate comt & $\begin{array}{l}\text { PR } \\
\text { Re } \\
\text { RI } \\
\text { SL }\end{array}$ & $\begin{array}{l}\text { c = maximuts } \\
=\text { not applic- } \\
\text { j = prejimin } \\
\text { - residentia } \\
=\text { retredistio } \\
=\text { screening }\end{array}$ & $\begin{array}{l}\text { ble } \\
\text { ry reme } \\
\text { n level } \\
\text { gyel }\end{array}$ & liation. & & & & \\
\hline
\end{tabular}


EU Z2-36 OTHER HISTORICAL SVOC DETECTS (UE/kg) 0-10 ft

\begin{tabular}{|c|c|c|c|c|c|c|c|c|}
\hline \multirow[b]{2}{*}{ Analyte } & \multirow[b]{2}{*}{$\begin{array}{c}\text { Doted } \\
\text { frequency }\end{array}$} & \multirow[b]{2}{*}{$\begin{array}{c}\text { Minimum } \\
\text { detect }\end{array}$} & \multirow[b]{2}{*}{$\begin{array}{l}\text { Mayimua: } \\
\text { detex }\end{array}$} & \multirow[b]{2}{*}{$\begin{array}{l}\text { Lochtion(s) of } \\
\text { maximumen detect }\end{array}$} & \multirow{2}{*}{$\begin{array}{l}\text { Average } \\
\text { detpectad } \\
\text { result }\end{array}$} & \multicolumn{3}{|c|}{$\begin{array}{l}\text { Nawher of analysex } \\
\text { exceding eriteria }\end{array}$} \\
\hline & & & & & & $\begin{array}{l}\text { Ind } \\
\text { PRG }\end{array}$ & $\begin{array}{l}\text { GW } \\
\text { SL }\end{array}$ & $\begin{array}{l}\text { Res } \\
\text { PRG }\end{array}$ \\
\hline 2-Myethylnapithalemt & 416 & $27.6 \mathrm{~J}$ & 53.90 & sól & 36.0 & 0 & $\mathrm{NA}$ & 0 \\
\hline Benza(a) anthracene & $3 / 6$ & 376 & 1,840 & Sol & 882 & 0 & NA & ] \\
\hline Benzo(a)pytent & $2 / 6$ & $358 \mathrm{~J}$ & 2,020 & SOI & 1,189 & 0 & NA & 2 \\
\hline Berzo(b)tituoranthere & $3 / 6$ & 393 & 2,270 & sol & 1,187 & 0 & NA & 2 \\
\hline Benzo(ghi)perylene & $3 / 6$ & $218 \mathrm{~J}$ & $1,390 \mathrm{~J}$ & SOI & 616 & 0 & $\mathrm{NA}$ & 0 \\
\hline Btrexo(k)iluorantheme & $3 / 6$ & 19 & 1,980 & 501 & $\$ 42$ & 0 & NA & 0 \\
\hline Bis(2-chy/hexyl)phuhalate & $2 / 6$ & $215 \mathrm{~J}$ & $340 \mathrm{~J}$ & sol & 278 & 0 & 0 & 0 \\
\hline Chrysene & $4 / 6$ & $197 \mathrm{~J}$ & 2,280 & SO: & 839 & 0 & $\mathrm{NA}$ & 0 \\
\hline Fherrenthene & 416 & 399 & 4,430 & sol & $1,6 \$ 88$ & 0 & $N_{A}$ & 0 \\
\hline Indeno( $(1,2,3$-ed)pyrene & $3 / 6$ & $209 \mathrm{~J}$ & $1,230 \mathrm{~J}$ & Sol & 554 & 0 & $N_{A}$ & $\mathrm{l}$ \\
\hline Pemlachlotopherond & $1 / 6$ & $\left.2 \beta \beta_{t}\right]$ & $280 \mathrm{~J}$ & sos & 280 & 0 & $N_{A}$ & 0 \\
\hline Phenanthrene & $4 / 6$ & $197 \mathrm{~J}$ & 3,420 & sol & $\mathbf{I}, \mathbf{I} 3 \mathbf{B}$ & 0 & NA & 0 \\
\hline PyTeme & $4 / 6$ & 378 & 4,400 & SOI & 1,654 & 0 & $\mathrm{NA}$ & 0 \\
\hline $\begin{array}{l}\text { EU = exprnate unit } \\
\text { GW = grouludwater } \\
\text { Ind = industrial } \\
f=\text { analyte was identified a } \\
\text { NA = nna applicathle }\end{array}$ & nd resule i & 0 & (PCC & $\begin{array}{l}\text { PRG = prel } \\
\text { Res = resid } \\
\text { RL = nemed } \\
\text { SL = screen } \\
\text { SVOC = se }\end{array}$ & $\begin{array}{l}\text { minary rem } \\
\text { antial } \\
\text { iation level } \\
\text { ing leved } \\
\text { miwolatile o }\end{array}$ & diation & $\bar{g} 9 \mathrm{l}$ & \\
\hline
\end{tabular}

EU Z2-36 OTHER HISTORICAL VOC DETECTS (ug/ks) 0-10 f

\begin{tabular}{|c|c|c|c|c|c|c|c|c|}
\hline \multirow[b]{2}{*}{ Antalyte } & \multirow[b]{2}{*}{$\begin{array}{c}\text { Detect } \\
\text { irequepncy }\end{array}$} & \multirow[b]{2}{*}{$\begin{array}{c}\text { Mfinlmum } \\
\text { detect }\end{array}$} & \multirow[b]{2}{*}{$\begin{array}{l}\text { Miximalm } \\
\text { detect }\end{array}$} & \multirow[b]{2}{*}{$\begin{array}{l}\text { Lacation(s) of } \\
\text { maximuma detect }\end{array}$} & \multirow{2}{*}{$\begin{array}{l}\text { Averaque } \\
\text { detected } \\
\text { result }\end{array}$} & \multicolumn{3}{|c|}{$\begin{array}{l}\text { Number of andlystes } \\
\text { exceetiog ctiteria }\end{array}$} \\
\hline & & & & & & $\begin{array}{c}\text { Ind } \\
\text { PRG }\end{array}$ & GW & $\begin{array}{c}\text { Res } \\
\text { PRG }\end{array}$ \\
\hline Medhylene chloride & $1 / 7$ & $1.1 \mathrm{~J}$ & I.IJ & sol & 1.1 & 0 & 0 & 0 \\
\hline Tedrachlordethene & $3 / 7$ & $0.76 \mathrm{~J}$ & $0.89 \mathrm{~J}$ & so3 & 0.83 & 0 & 0 & 0 \\
\hline Tohuenc & $3 / 7$ & $0.32 \mathrm{~J}$ & $0.85 \mathrm{~J}$ & 502 & 0.55 & 0 & 0 & 0 \\
\hline $\begin{array}{l}\text { EU = exposurc unit } \\
\text { GW = gnoundwater } \\
\text { Ind = industrial } \\
J=\text { analyte was ident } \\
\text { NA - not applicable }\end{array}$ & and resalt is & min & Eentralion & \multicolumn{5}{|c|}{ 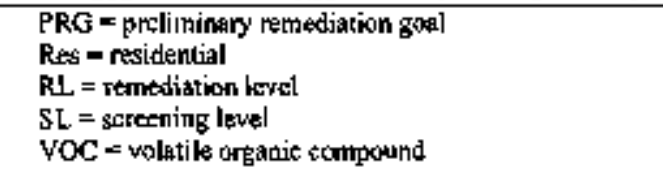 } \\
\hline
\end{tabular}

EU Z2-36 Sumnıry: This section presents a summary of the nature and extent of chemicals and radionuclides in the EU by combiring all of the enalytical data presented in the focused investigation suminaries above. The two Zone 2 ROD Appendix A FFA sites in EU Z2-36 are evaluated above as parts of the K-1501-A/B Class 2 SU and $\mathrm{K}-1501-\mathrm{J}$ Class $2 \mathrm{SU}$.

There are 36 sample locations in EU Z2-36. PCB-1254 and polychlorinated biphenyl Avg RLs were exceeded at sample location Z2-EU36B-301, the sediment sample location from the K-1401 storn drain. There are also metal, PCB, rationuclide, atd SVOC Ind PRG exceetances and metal and radionclide Bkg exceedances. DRO was detected at one sample location in the K-1501-A/B Class 2 SU (Z2-EU36-208), one sample location in the K-1501-J Class 2 SU (Z2-EU36-210), and the sample location in the K-1501 sump (Z2-EU36B-310). GRO was detected at three sample locations in the K-1501-A/B Class 2 SU (Z2-EU36-206, Z2-EU36-208, and 22-EU36-209) and one sample location in the K-150)-J Class 2 SU (Z2-EU36-210). Also detected were PCBs, SVOCs, and VOCs.

EU Z2-36 METALS WITH BACKGROUND,

PRG, GW SL, AND/OR RL EXCEEDANCES (mg/ka) o-10 fi

\begin{tabular}{|c|c|c|c|c|c|c|c|c|c|c|c|}
\hline \multirow[b]{2}{*}{ Antutyte } & \multirow[b]{2}{*}{$\begin{array}{c}\text { Detect } \\
\text { frequetiony }\end{array}$} & \multirow[b]{2}{*}{$\begin{array}{c}\text { Minimimm } \\
\text { detect }\end{array}$} & \multirow[b]{2}{*}{$\begin{array}{c}\text { Maximum } \\
\text { deter }\end{array}$} & \multirow{2}{*}{$\begin{array}{c}\text { Lecationes) of } \\
\text { maximum } \\
\text { detext }\end{array}$} & \multirow{2}{*}{$\begin{array}{c}\text { Average } \\
\text { detected } \\
\text { rętult }\end{array}$} & \multicolumn{6}{|c|}{ 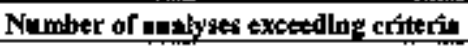 } \\
\hline & & & & & & $\begin{array}{c}\text { Matx } \\
\text { RL }\end{array}$ & $\begin{array}{l}\text { Ave } \\
\text { RL }\end{array}$ & $\begin{array}{l}\text { Iod } \\
\text { PRG }\end{array}$ & Ekx & $\begin{array}{l}\text { GW } \\
\text { SL }\end{array}$ & $\begin{array}{l}\text { Res } \\
\text { PRG } \\
\end{array}$ \\
\hline Alखmixum & $26 / 26$ & 1,400 & 24,000 & $22-E \bigcup 36-202$ & 12,802 & NA & NA & 0 & o & NA & 20 \\
\hline Antimony & $21 / 26$ & 0.016 & $2.4 \mathrm{~J}$ & Z2-EU36B-310 & 0338 & $\mathrm{NA}$ & $\mathrm{NA}$ & 0 & 2 & 0 & 0 \\
\hline Arsenit & $25 / 26$ & 0.97 & 37 & Z2-EU36B-303 & 8.55 & 0 & 0 & 3 & 3 & 0 & 25 \\
\hline Bariutn & $26 / 26$ & 47 & 260 & $22-E \cup 36 B-303$ & 113 & NA & NA & 0 & $T$ & 0 & 0 \\
\hline Carmium & $26 / 26$ & 0.1 & 4.68 & SOl & 0.634 & NA & NA & 0 & 18 & NA & 1 \\
\hline
\end{tabular}


EU Z3-36 METALS WITH BACKGROUND,

PRG, GW SL, ANDIOR RL EXCEEDANCES (mitht) 0-10 ft (cont)

\begin{tabular}{|c|c|c|c|c|c|c|c|c|c|c|c|}
\hline \multirow[b]{2}{*}{ Analyde } & \multirow[b]{2}{*}{$\begin{array}{c}\text { Detext } \\
\text { frequency }\end{array}$} & \multirow[b]{2}{*}{$\underset{\text { deted }}{\text { Muimun }}$} & \multirow[b]{2}{*}{$\begin{array}{c}\text { Maximumat } \\
\text { deteet }\end{array}$} & \multirow{2}{*}{$\begin{array}{l}\text { Location(s) of } \\
\text { meximnm } \\
\text { detect }\end{array}$} & \multirow{2}{*}{$\begin{array}{l}\text { Avarage } \\
\text { detected } \\
\text { renuli }\end{array}$} & \multicolumn{6}{|c|}{ Nember of andyses exceeding criterla } \\
\hline & & & & & & $\begin{array}{c}\text { MaI } \\
\text { RL }\end{array}$ & $\begin{array}{l}\text { Avg } \\
\text { RL }\end{array}$ & $\begin{array}{l}\text { ind } \\
\text { PRG }\end{array}$ & Bke & $\begin{array}{l}\mathbf{G W} \\
\mathbf{S L}\end{array}$ & $\begin{array}{c}\text { Res } \\
\text { PRG }\end{array}$ \\
\hline Calcium & 2626 & 1,400 & 250,000 & Z2-EU36-203 & 42,315 & NA & NA & $\mathrm{NA}$ & 22 & NA & $\mathrm{NA}$ \\
\hline Chromium & 26266 & 9.885 & 160 & Z2-EU36B-30I & 35.6 & NA & $\mathrm{NA}$ & 0 & 2 & $\sqrt{0}$ & 19 \\
\hline Coppet & 26126 & II & 321 & sol & 79.9 & NA & $N_{A}$ & 0 & 20 & NA & I \\
\hline Iron & 26,26 & 8.800 & 140,000 & 22-EU36B-303 & 33227 & NA & NA & 1 & 1 & NA & 26 \\
\hline Lead & $26 / 26$ & 7.7 & 340 & 22-EU36B-301 & 41.1 & NA & $\mathrm{NA}$ & 0 & 6 & 0 & 0 \\
\hline Magnesinum & $26 \sqrt{26}$ & $78 \mathrm{~J}$ & 65,000 & 72-EU36B-301 & 12,094 & $\mathrm{NA}_{\mathrm{A}}$ & NA & NA & 19 & NA & $\mathrm{Na}$ \\
\hline Manganese & $26 / 26$ & 180 & 4,200 & Z2-EU36B-307 & 1,010 & $\mathrm{NA}$ & $\mathrm{NA}$ & 0 & $\mathbf{I}$ & NA & 26 \\
\hline Maricury & $25 / 26$ & 0.0061 & $1.98 \mathrm{~J}$ & sol & 0.158 & 0 & 0 & 0 & 5 & $N_{A}$ & 0 \\
\hline Nicked & $26 / 26$ & 15 & 613 & sol & 119 & $N A$ & $N A$ & to & 20 & NA & 5 \\
\hline Seleniurn & $7 / 26$ & $0.323 \mathrm{~J}$ & 3 & Z2-EU36B-310 & 1.63 & NA & $\mathrm{NA}$ & 0 & 5 & NA & 0 \\
\hline Silver & $\$ \$ 26$ & 0.082 & $0.819 \mathrm{~J}$ & sol & 0.420 & NA & $N_{A}$ & 0 & $\underline{2}$ & $N_{A}$ & 0 \\
\hline Thallitm & $21 / 26$ & 0.043 & $0.54 \mathrm{~J}$ & Z2-EU36B-ЭI0 & 0.217 & $N A$ & $\mathrm{NA}$ & 0 & I & 0 & 1 \\
\hline Uraniñm & $21 / 21$ & 0.38 & 4.7 & 22-EL36B-308 & 1.46 & NA & NA & 0 & NA & $\mathrm{NA}$ & $g$ \\
\hline Vanadium & $26 / 26$ & 6.6 & 56 & $22-E \omega 36-210$ & 26.4 & NA & NA & th & 0 & NA & 25 \\
\hline Zinc & $26 / 26$ & 23 & 390 & Z2-EU36B-30I & 98.8 & $N_{A}$ & $\mathrm{NA}$ & 0 & 8 & $N A$ & 0 \\
\hline \multicolumn{5}{|c|}{$\begin{array}{l}\text { Avg = average } \\
\text { Bkg = backgrownd } \\
\text { BU = exposure unit } \\
\text { GW = groundwater } \\
\text { Ind = industrial } \\
\mathbf{J}=\text { analyte was idertified a }\end{array}$} & \multicolumn{7}{|c|}{ Max = maximum } \\
\hline
\end{tabular}

EU Zz-36 OTHER ORGANICS DETECTS $(\mathrm{mg} / \mathrm{kg})$ 0-10 ft

\begin{tabular}{|c|c|c|c|c|c|}
\hline Anplyte & $\begin{array}{l}\text { Detect } \\
\text { frequency }\end{array}$ & $\begin{array}{c}\text { Mitimulin } \\
\text { deteret }\end{array}$ & $\begin{array}{c}\text { Maximum } \\
\text { dottect }\end{array}$ & $\begin{array}{l}\text { Loestion(s) of } \\
\text { maxintule detect }\end{array}$ & $\begin{array}{l}\text { Average } \\
\text { detected } \\
\text { reptult }\end{array}$ \\
\hline Diesel Range Organics & $3 / 8$ & 521 & $860 \mathrm{~J}$ & 20 -EƯ $36-200$ & 342 \\
\hline $\begin{array}{l}\text { Gasoline Range } \\
\text { Organicts }\end{array}$ & $4 / 8$ & $0.16 \mathrm{~J}$ & 25 & 22-EU36-208 & 7.36 \\
\hline
\end{tabular}

EU Z2-36 PPCB DETECTS (ux/kg) 0-10 ft

\begin{tabular}{|c|c|c|c|c|c|c|c|c|c|}
\hline \multirow[b]{2}{*}{ Antyle } & \multirow[b]{2}{*}{$\begin{array}{l}\text { Detect } \\
\text { irequancy. }\end{array}$} & \multirow[b]{2}{*}{$\begin{array}{c}\text { Minimum } \\
\text { detect }\end{array}$} & \multirow[b]{2}{*}{$\begin{array}{l}\text { Maximumal } \\
\text { detect }\end{array}$} & \multirow{2}{*}{$\begin{array}{c}\text { Loctition(s) of } \\
\text { maximum } \\
\text { detect }\end{array}$} & \multirow{2}{*}{$\begin{array}{c}\text { Average } \\
\text { detecled } \\
\text { resull }\end{array}$} & \multicolumn{4}{|c|}{$\begin{array}{l}\text { Number of endyites } \\
\text { exceeting criteria }\end{array}$} \\
\hline & & & & & & $\begin{array}{l}\text { Max } \\
\text { RL. }\end{array}$ & $\begin{array}{l}\text { Ave } \\
\text { RL }\end{array}$ & $\begin{array}{l}\text { Ind } \\
\text { PRG }\end{array}$ & $\begin{array}{l}\text { Res } \\
\text { PRG }\end{array}$ \\
\hline $\mathrm{PCB}-1254$ & $\mathrm{~B} / 27$ & $8.1 \mathrm{~J}$ & 16,000 & Z2-EU36B-301 & 2,166 & 0 & 1 & 1 & 3 \\
\hline$P C B-1260$ & $11 / 27$ & IlJ & 249 & S01 1 & 58.6 & 0 & 0 & 0 & $\mathbf{I}$ \\
\hline Polychlorisated biphetyl & $11 / 21$ & 8.]J & 16,000 & Z2-EU36B-301 & 1,504 & 0 & 1 & 1 & 2 \\
\hline $\begin{array}{l}\text { Avs - average } \\
\text { EU = exposure unit } \\
\text { [nd = industrial } \\
\text { J - atratyle was idendified } \\
\text { Max = maximum }\end{array}$ & risut & 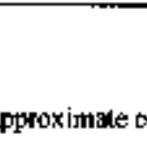 & & \multicolumn{6}{|c|}{$\begin{array}{l}\text { PPCB - pesticide and polychloridaled bipherryl } \\
\text { PRG = preliminary remodiation gas } \\
\text { Res = residential } \\
\text { RL = remediation level }\end{array}$} \\
\hline
\end{tabular}

EU Z2-36 RADJONUCLIDES WTTH

BACKGROUND, PRG, ANDOOR RL EXCEEDANCES (pCirg) at- $10 \mathrm{ft}$

\begin{tabular}{|c|c|c|c|c|c|c|c|c|c|c|c|}
\hline \multirow[b]{2}{*}{ Analyte } & \multirow[b]{2}{*}{$\begin{array}{c}\text { Detect } \\
\text { irequescy }\end{array}$} & \multirow[b]{2}{*}{$\begin{array}{l}\text { Minimum } \\
\text { defect }\end{array}$} & \multirow[b]{2}{*}{$\begin{array}{l}\text { Maxlmum } \\
\text { detect }\end{array}$} & \multirow[b]{2}{*}{$\begin{array}{l}\text { Location(s) of } \\
\text { muxisun detect }\end{array}$} & \multirow{2}{*}{$\begin{array}{l}\text { Average } \\
\text { detected } \\
\text { result }\end{array}$} & \multicolumn{6}{|c|}{ Number of anabyes exceeding trilerit } \\
\hline & & & & & & $\begin{array}{c}\text { Max } \\
\text { RL }\end{array}$ & $\begin{array}{l}\text { Avg } \\
\text { RL }\end{array}$ & $\begin{array}{l}\text { Ind } \\
\text { PRG }\end{array}$ & Bkg & $\begin{array}{l}\text { GW } \\
\text { SL }\end{array}$ & $\begin{array}{l}\text { Res } \\
\text { PRG }\end{array}$ \\
\hline$\overline{C e s i u m-137}$ & $12 / 24$ & $0 . J 1$ & 124 & $\$ 01$ & 0.550 & 0 & 0 & 2 & NA & NA & 12 \\
\hline Pota5sium-40 & $\mid \mathrm{I} / 2$ & 3.943 & 29.9 & ETTP-RELOG & 19.2 & NA & $\mathrm{NA}$ & I] & 0 & NA & I] \\
\hline Radium-226 & $3 / 3$ & 0.757 & l & ETTP-RELOT & 0.891 & $\mathrm{NA}$ & NA & 3 & 0 & NA & 3 \\
\hline Technetium-9s & $2 / 24$ & 2.94 & 13.1 & $27-E \cup 36 \mathrm{~B}-301$ & $\$ .02$ & NA & NA & 0 & $N_{A}$ & NA & 2 \\
\hline Tharium-228 & $23 / 24$ & $0.679 \mathrm{~J}$ & 1.83 & 22-EU36-210 & $1.2 \mathrm{~d}$ & $N A$ & $\mathrm{NA}$ & 23 & 0 & $\mathrm{~N} A$ & 23 \\
\hline Thorium-230 & $22 / 24$ & $0.228 \mathrm{~J}$ & 2.15 & Z2-EU36-210 & 1.19 & $\mathrm{NA}$ & $N_{A}$ & 0 & 11 & $\mathrm{NA}$ & 0 \\
\hline
\end{tabular}


EU Z2-36 RADIONUCLIDES WTH

BACKGROUND, PRG, AND/OR RL EXCEEDANCES (pCW/) 0-10 fl (conL)

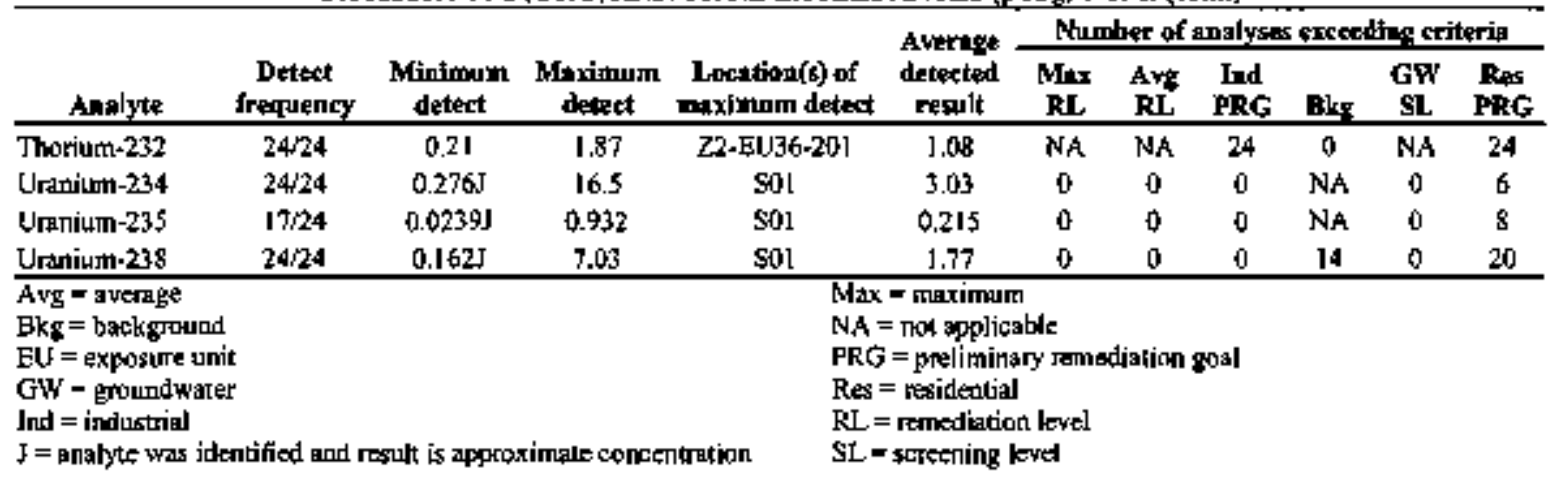

EU 22-36 SVOC DETECTS (UKMkg) 0-1) ft

\begin{tabular}{|c|c|c|c|c|c|c|c|c|}
\hline \multirow[b]{2}{*}{ Analyte } & \multirow[b]{2}{*}{$\begin{array}{c}\text { Detert } \\
\text { frequenty }\end{array}$} & \multirow[b]{2}{*}{$\begin{array}{c}\text { Minimum } \\
\text { detext }\end{array}$} & \multirow[b]{2}{*}{$\begin{array}{c}\text { Maximum } \\
\text { deteet }\end{array}$} & \multirow[b]{2}{*}{$\begin{array}{l}\text { Location(s) of } \\
\text { maximem detat }\end{array}$} & \multirow{2}{*}{$\begin{array}{l}\text { Average } \\
\text { detected } \\
\text { result }\end{array}$} & \multicolumn{3}{|c|}{$\begin{array}{l}\text { Number of amolyses } \\
\text { exceedinf eriturit }\end{array}$} \\
\hline & & & & & & $\begin{array}{l}\text { End } \\
\text { PRG }\end{array}$ & $\begin{array}{l}G W \\
G L\end{array}$ & $\begin{array}{l}\text { Res } \\
\text { PRG }\end{array}$ \\
\hline I-Methylngphtha]era & $2 / 4$ & 819 & 991 & Z2-Eu3619-304 & 90 & $N_{A}$ & $\mathrm{NA}$ & NA \\
\hline 2,d-Dimethylphenol & $1 / 27$ & $94 \mathrm{~J}$ & 94J & Z2-EU36B-310 & 9.4 & 0 & NA & 0 \\
\hline 2-Methylnaphthakene & $13 i 27$ & $27.6 \mathrm{~J}$ & 10,000 & Z2-EU36-203 & 1,217 & 0 & $\mathrm{NA}$ & 1 \\
\hline Acentaphuhene & $2 / 2 \tau$ & 520 & 10,000 & 22. EU136B. 310 & 5,260 & 0 & NA & 0 \\
\hline Actaphlhylene & $2 / 2 T$ & $84 J$ & $150 \mathrm{~J}$ & Z2-EU36-203 & 117 & 0 & NA & 0 \\
\hline Anthrocene & $6 / 27$ & $\$ 11$ & 28,000 & $22-E \circlearrowleft 36 \mathrm{~B}-310$ & 4,919 & 0 & NA & 0 \\
\hline Bend(a) anthractere & $9 / 27$ & 3600 & 31,1000 & Z2.EUF36B-310 & 4,452 & 1 & $\mathrm{NA}$ & 4 \\
\hline Benzo(a)pyrzene & $B / 2 T$ & $358 J$ & 25,000 & 22-EU36B-310 & 4,259 & 2 & $N_{A}$ & B \\
\hline Benax(b) flucranthene & $10 / 27$ & 1201 & $34,0,0,0$ & 22-EU36B-310 & $\$, 024$ & l & NA & 6 \\
\hline Benzo(ghi)perylene & $B / 27$ & $160 \mathrm{~J}$ & 5,200 & Z2-EU36B-310 & 1.492 & 0 & Nh & 0 \\
\hline Benzon(k)fluoranthene & $9 / 27$ & 1921 & $15,0,00$ & $22-E U 36 \mathrm{~B}-310$ & 2,469 & 0 & NA & 1 \\
\hline Bis(2-ethylhexyl)ptuhalate & $5 / 27$ & 215J & $3,000 \mathrm{~J}$ & Z2-EU36B-301 & 969 & 0 & 0 & 0 \\
\hline Cajbazole & $3 / 27$ & $120 \mathrm{~J}$ & $88_{r} 500$ & Z2-EU360-310 & 3,020 & 0 & $\mathrm{NA}$ & 0 \\
\hline Chyssene & $9 / 26$ & $197 \mathrm{~J}$ & 2,2 乩 & sol & 942 & 0 & NA & 0 \\
\hline Dithetg(4,h)anlhracane & $3 / 2 T$ & 3901 & 1,700 & Z2-EU36B-310 & 957 & 0 & $N A$ & 3 \\
\hline Dibenzoturan & $2 n T$ & $270 \mathrm{~J}$ & $T_{2} 200$ & 22-EU36B-310 & 3,735 & 0 & NA & 0 \\
\hline Fluograntherde & 1227 & $79 \mathrm{~J}$ & 91,000 & 22-EU36B-310 & 9,073 & 0 & $N A$ & 0 \\
\hline Fhorene & $3 / 2 \tau$ & $2 \$ 0 \mathrm{~J}$ & $11,00 \%$ & 22-EU36日-310 & 4,010 & 0 & NA & 0 \\
\hline Indeno( $1,2,3-c d)$ pyrene & $9 / 27$ & $160 \mathrm{~J}$ & $(0,0) 00$ & Z2-EU36B-310 & 1,815 & 0 & NA & 4 \\
\hline Naptulhalene & 10.38 & $7 \pi \mathrm{I}$ & $7,400 \mathrm{~J}$ & Z2-EU36-2018 & 1,350 & 0 & NA & l \\
\hline Pentachkrophepol & $1 / 27$ & $280 \mathrm{~J}$ & $280 \mathrm{~J}$ & SOB & 280 & 0 & NA & 0 \\
\hline Phenanthrene: & $13 / 27$ & $37 \mathrm{~J}$ & $B 5,0000$ & Z2-EU36B-310 & 7,453 & 0 & $N_{\AA}$ & l \\
\hline Pyrene & $13 \sqrt[27]{27}$ & \$ J & $? 1,0,0$ & $22-E U 36 \mathrm{~B}-310$ & $3,4] 3$ & 0 & NA & 0 \\
\hline $\begin{array}{l}\text { EU = exposure unit } \\
G W=\text { sccundwater } \\
\text { Ind = industrial } \\
\text { J = analyte wes identifico } \\
\text { NA = not applicable }\end{array}$ & & & 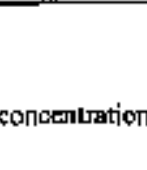 & $\begin{array}{l}\text { PRG = pre } \\
\text { Rts = resiô } \\
\text { RL = reme } \\
\text { SL = seres } \\
\text { SVOC = se }\end{array}$ & $\begin{array}{l}\text { nimary retr } \\
\text { arial } \\
\text { alion kesel } \\
\text { ng leves } \\
\text { ivobatile } 0\end{array}$ & iediatio & & \\
\hline
\end{tabular}

EU Z2-36 VOC DETECTS (ng/kg) 0-t0 it

\begin{tabular}{|c|c|c|c|c|c|c|c|c|}
\hline \multirow[b]{2}{*}{ Analyte } & \multirow[b]{2}{*}{$\begin{array}{l}\text { Detect } \\
\text { frequency }\end{array}$} & \multirow[b]{2}{*}{$\underset{\text { detect }}{\text { Minimmm }}$} & \multirow[b]{2}{*}{$\begin{array}{l}\text { Mingimum } \\
\text { defect }\end{array}$} & \multirow[b]{2}{*}{$\begin{array}{l}\text { Locstlon(n) of } \\
\text { miximum detect }\end{array}$} & \multirow{2}{*}{$\begin{array}{l}\text { Averase } \\
\text { detected } \\
\text { result }\end{array}$} & \multicolumn{3}{|c|}{$\begin{array}{l}\text { Numbur of analytes } \\
\text { exceeding criteria }\end{array}$} \\
\hline & & & & & & $\begin{array}{l}\text { Yod } \\
\text { PRO }\end{array}$ & $\begin{array}{l}\text { GW } \\
\text { SL }\end{array}$ & $\begin{array}{l}\text { RPE } \\
\text { PRG }\end{array}$ \\
\hline (1,1-Dintechylealhyl)be|zzeue & $\mid / I 1$ & 390 & 390 & $22-E U 36-208$ & 390 & 0 & $\mathrm{NA}$ & 0 \\
\hline (I-Mathytpropyl)benzene & $2 / 1$ & 21 & 1,300 & Z2-EU36-208 & $66 \mathbf{~}$ & 0 & $\mathrm{NA}$ & 0 \\
\hline 1,2,4-Trimethylbenzene & נll & 459 & $47,0,00$ & $22-E \cup 36.208$ & 23,500 & 0 & NA & $\mathbf{I}$ \\
\hline 12-Dichloropropane & $1 / 18$ & $250 \mathrm{~J}$ & $250 \mathrm{~J}$ & Z2-EU36-208 & 250 & 0 & NA & 0 \\
\hline 1)-Dimethylbarzenc & $\mathbf{l} / \mathbf{I}$ & 23,000 & 23,000 & $22-E \cup 36.206$ & 23,0000 & 0 & NA & 0 \\
\hline 1,3,5-Trimerhylbouzejse & $|/| l$ & 20,000 & 20,0000 & $\mathrm{Z2}-\mathrm{E} \cup 36-208$ & 20,000 & 0 & $\mathrm{NA}$ & $\mathbf{I}$ \\
\hline
\end{tabular}


EU Z2-36 VOC DETECTS (4e/kg) 0-10 îl (contd.)

\begin{tabular}{|c|c|c|c|c|c|c|c|c|}
\hline \multirow[b]{2}{*}{ A.Dabyte } & \multirow[b]{2}{*}{$\begin{array}{c}\text { Datect } \\
\text { frequency }\end{array}$} & \multirow[b]{2}{*}{$\begin{array}{l}\text { Minlmum } \\
\text { detect }\end{array}$} & \multirow[b]{2}{*}{$\begin{array}{l}\text { Maximnom } \\
\text { dẹtect }\end{array}$} & \multirow[b]{2}{*}{$\begin{array}{l}\text { Lacations(s) of } \\
\text { maximuIp detect }\end{array}$} & \multirow{2}{*}{$\begin{array}{l}\text { Averise } \\
\text { detected } \\
\text { regult }\end{array}$} & \multicolumn{3}{|c|}{$\begin{array}{l}\text { Number of antyres } \\
\text { excepding Giterin }\end{array}$} \\
\hline & & & & & & $\begin{array}{l}\text { Ind } \\
\text { PRG } \\
\end{array}$ & $\begin{array}{l}\text { GW } \\
\text { SL }\end{array}$ & $\begin{array}{l}\text { Res } \\
\text { PRC }\end{array}$ \\
\hline $\begin{array}{l}\text { I-Hethyl-4-(I-methylathyl) } \\
\text { betzene }\end{array}$ & $2 / 11$ & 14 & 3,800 & $Z 2-E U 36-20,8$ & 1,907 & NA & NA & NA \\
\hline 2-Bulanoue & ]/18 & 835 & $83 J$ & Z2-EU36-203 & $B 3$ & 0 & NA & 0 \\
\hline Actone & $3 / 18$ & $17]$ & $40 \mathrm{ds}$ & Z2-Eل $36 \mathrm{~B}-303$ & 326 & 0 & NA & 0 \\
\hline Benzene & IIS & 640 & 640 & 22-EU36-208 & 640 & 0 & 0 & 0 \\
\hline Butylberizene & 2111 & 22 & 2,900 & $27-E U 36-208$ & 1,461 & 0 & NA & 0 \\
\hline Cumene & $2 / 11$ & 15 & 3,000 & Z2-EU36-208 & 1,508 & 0 & NA & 0 \\
\hline Elhylbenzene & $2 / 19$ & 11 & 20,6000 & 22-EU36-208 & 10,006 & 0 & NA & 0 \\
\hline$M+P X y l c a k$ & $2 / 12$ & $2 \mathrm{IJ}$ & 65,000 & Z2-EU36-208 & 32,301 & 0 & NA & 1 \\
\hline Methylene thlonde & I/18 & I IJ & I IJ & S01 & | I & 0 & 0 & 0 \\
\hline Prapylbencene & $2 / 11$ & 25 & 6,500 & 22-EU36-208 & 3,263 & 0 & NA & 0 \\
\hline Tetraclulorothene & $3 / 8$ & $076 J$ & 0 (99] & 503 & 083 & 0 & 0 & 0 \\
\hline Tulueste & $4 / 19$ & 0321 & 4,4001 & 22-EU36-2018 & $1,100)$ & 0 & 0 & 0 \\
\hline $\begin{array}{l}\text { EU = exposure unt } \\
\text { GW = groundwalet } \\
\text { lod = Industual } \\
J * \text { andlye was Identıfied an } \\
\text { NA = nod applicable }\end{array}$ & esult is appro & ximate conce & Jation & $\begin{array}{l}\text { PRG = prelizusuary re } \\
\text { REs = resudentıal } \\
\text { RL = remediatıon lew } \\
\text { SL = sereanog level } \\
\text { YOC = volatıke organ }\end{array}$ & ediodion go: & & & \\
\hline
\end{tabular}

$\mathbf{2 , 2 , 6}$

ZONE 2 ROD APPENDIX A FFA STTES EVALUATHON

Th1s section presents charactenzation summanes for FFA sites in EU Z2-36 FFA charactenzatoon area sites listed in Appendix $A$ of the Zone 2 ROD are the primary concern However, other FFA sites aiso may be addressed There are two FFA stes in EU Z2-36 - the K-1098-C Asphalt Plant FFA site and the K-1503 Neutraluzation Pit FFA site

K-1098-C Asphalt Plant FFA Site: The K-1098-C FFA Site is located in the interior portion of the K-1501-A/B Class 2 SU Sanpling to charactenze this FFA site was conducted as part of the Class 2 SU charactenzation actuvtles descrubed in Sects 2123 and 225

K-1503 Neutralization Pit FFA Site: The K-1503 Neutralization Pil FFA Sute is located in the K-1501-J Class 2 SU Sampling to characterize this FFA site was conducted as part of the Class 2 SU charactenzation activities described in Sects 2123 and 225

\begin{tabular}{|l|l|}
\hline 3.0 & \multicolumn{1}{|c|}{ RISK EVALUATION AND ACTION/NO FURTHER ACTION DECISION } \\
\hline 3.1 & INTRODUCTION \\
\hline
\end{tabular}

In this section, data are evaluated in terms of the four decision rules presented in the Zone 2 RAWP The decision rules itclude

- Does the concentration of any Zone 2 contammant of concern (COC) exceed its maximum RL?

- Does the mean concentration of any Zone 2 COC exceed its average RL actoss the EU?

- Does the EU pose a nsk exceeding an tndustral $1 \times 10^{4}$ excess lifetıme cancer risk (ELCR) or target organ bazard index (HI) of $1^{\prime}$

- Does the site pose a threat to groundwater based on MCL exceedancts or soll RLs for protection of groundwater?

Results from comparison of the data to Zone 2 sols RLs, Ind PRGs (set at an ELCR of $1 \times 10^{5}$ or a HI of 1 ), and background lewels is presented on Table A 3 In addiuon, the EU summary in Sect 225 presents an evaluation of data by analyte group The conclusions for current conditions in EU Z2-36 are summanized in the followng table 


\begin{tabular}{|c|c|c|c|c|c|}
\hline EU \# & $\begin{array}{l}\text { Max RL } \\
\text { exceeded? }\end{array}$ & $\begin{array}{l}\text { Average RL over } \\
\text { EU exceeded? }\end{array}$ & $\begin{array}{l}\text { Industrial risk } \\
\text { above } 1 \times 10^{-4} \text { ? }\end{array}$ & $\begin{array}{l}\text { Potential source } \\
\text { to groundwater? }\end{array}$ & $\begin{array}{c}\text { Action } \\
\text { required? }\end{array}$ \\
\hline $72-36$ & No & $\mathrm{N}_{0}$ & No & No & $\mathrm{No}$ \\
\hline \multicolumn{6}{|c|}{$\begin{array}{l}\text { EU - exposure unil } \\
\text { RL }- \text { remediation ketel }\end{array}$} \\
\hline 3.2 & DATA EVALD & FOR THE ACTION & FUR'THER ACTIO & ECISION & \\
\hline
\end{tabular}

The requirements for determining NFA in the Zone 2 EUs are stated in the protection goals of the Zone 2 ROD remedial action objective. Four decision rules developed in the DVS DQOs state the specific criteria against which each EU nust be compared to make the NFA decision. These four decision rules are presented in Sect. 3.2 of this PCCR, The way decision rule evaluations are conducled and special data handling requirernents are discussed in Sect. 3.3. In summary, the decision mite criteria for NFA are that each EU must meet each of the following compositional constraints:

- Zone 2 soils Max RLs-maximum allowable conentrations of Zone 2 soils COCs. Zone 2 soils Max RLs are presented in the Zone 1 ROD and Seet. 3.2 of this PCCR.

- Zone 2 soils Avg RLs-limit on the allowable average concentrations of Zone 2 soils COCs actoss an EU. Zone 2 soils Avg RLs are presented in the Zone 1 ROD and Sect. 3.2 of this PCCR.

- Cumulative risk across the EU-eumulative risk across an EU cannot exeed l $\times 10^{-4}$ ELCR or HI of 1 . A stepwise evaluation of cumulative risk is performed by comparing EU data to $1 \times 10^{5}$ industrial PRGs. The $1 \times 10^{-5}$ Ind PRGs for the analytes tequired by the RDR/RAWP are presented in Sect. 3.2 of this PCCR.

- Groundwater protection goals-composition of Zone 2 soils cannot pose a threat to groundwater. This evaluation is conducted by assessing local groundwater monitoring resulis and comparing soils composition to calculated SLs. Groundwater SLS are presented in Sect. 3.2 of this PCCR.

\begin{tabular}{|l|l|}
\hline 3.3 & SUMMARY AND CONCLUSIONS \\
\hline
\end{tabular}

EU Z2-36

In this section, soils composition from the 0-10-ft depth interval in EU Z2-36 are evaluated in terms of the decision nule criteria discussed in Sect. 3.2 of this PCCR.

Maximum RL screnting. There are no Max RI exceedances in EU Z2-36.

Average RL sereening. The AV RL screening process includes the Zone 2 ROD requiretitent that the wejghted average coneentrations of Zone 2 COCs across the EU may not exceed their respective Avg RLs. The screening process begins by documenting the individual locations of Avg RL exceedances in the EU. Next, the average detected concentration of any $C O C$ with an $\mathrm{Avg} \mathrm{RL}$ exceedance is compared to the Avg RL. If the detected average concentration is less than the Avg RL, then the COC is dropped from further screening. If a COC's average detected concentration exceeds the Avg RL, then a new average concentration is calculated where half the value of the detection limt is used for nondetects. If the new average exceeds the Avg $\mathrm{RL}$, then a weighted average concentration for the $\mathrm{COC}$ is calculated and the weighted average concentration is compared to the Avg RL.

The first step in the Avg RL screen, comparison of average detected concentrations to Avg RLs, is presented in the following table. Two Avg RLs, PCB-1254 and polychlorinated biphenyl, were exceeded and both exceedances cocurred at the K-140l stom drain sediment sample location. 
Average detected concentrations of analytes with Avg RL exceedances conpared to Avg RLs

\begin{tabular}{lcccc}
\hline $\begin{array}{c}\text { Analyte with Avg RL } \\
\text { exceedance(s) }\end{array}$ & $\begin{array}{c}\text { Number of } \\
\text { exceedances }\end{array}$ & $\begin{array}{c}\text { Avg RL } \\
(\mathbf{u g} / \mathbf{k g})\end{array}$ & $\begin{array}{c}\text { Average detected } \\
\text { concentration } \\
\text { (0g/kg) }\end{array}$ & $\begin{array}{c}\text { Exceeds Avg } \\
\text { RL? }\end{array}$ \\
\hline PCB-1254 & 1 & 10,000 & 2,166 & No \\
Polychlonnaled brphenyl & 1 & 10,000 & 1,504 & No \\
\hline
\end{tabular}

Avg - averrage

$R \perp=$ ramediatıon leved

Thus, it is concluded there are no Avg RL exceedances across EU Z2-36

Rusk evaluation The $1 \times 10^{5}$ Ind PRGs are used as an mutal screen to test for the possibulity that a $1 \times 10^{4}$ industral nsk would be exceeded The first step in the nsk screen is to document all of the chemicals and radionuclides with $1 \times 10^{5}$ Ind PRG exceedances The $1 \times 10^{3}$ Ind PRGs for Ra-226, Th-228, Th-230, and Th-232 are not considered in the nsk evaluation because nsk for those radjonuclides is evaluated with the Ra/Th decay serres $R L_{s}$, and $K-40$ is considered in the rusk evaluation only if its average detected concentratton exceeds its background concentration. The second step in the risk screen is to compare the average detected concentratrons of chemicals and radionuclides with individual Ind PRG exceedances to the $1 \times 10^{5}$ Ind PRGs If the average delected concentration of a chemical or radionuclide is less than the $1 \times 10^{1}$ Ind PRG, that chemical or radionuclide is no longer evaluated for risk If the average detected concentration of a chemucal or radionuclide exceeds the $1 \times 10^{5}$ Ind PRG, then the average concentration is rectalculated using one-half the detection limut for nondelects If the recalculated average concentraton exceeds the $1 \times 10^{4}$ Ind PRG (1 e, 10 tumes the $1 \times 10^{5}$ Ind PRG), then a weighted average calculation is performed (weighted average is explanet in this POCR) if the werghted average exceeds the $1 \times 10^{4}$ Ind PRG, then a quantatatve risk assessment is performed Lastly, all chemrals and radicuucindes with individual $1 \times 10^{3}$ Ind PRG exceedances are evaluated for their combined inpact on cumulative nik An estemate of cumulative nsk is made by calculatmg the fraction tach average concentration is of its $1 \times 10^{5}$ Ind PRG, then surnming those fractions If the sum is $>75$ ( 1 e, approximately $75 \%$ of the $I \times 10^{4}$ Ind PRGs), then the need for quantitatuve nsk assessment is evaluated

The Aata summanes in Sect 225 illustrate there are several metal, PCB, and SVOC Ind PRG exceedances in EU Z2-36 As described above, the Ra-226, Th-228, Th-230, and Th-232 Ind PRG exceedances are not consulered and, because the average detected concentration is less than the background concentration ( $3212 \mathrm{pC} 1 / \mathrm{g})$, the $\mathrm{K}-40$ Ind PRG exceedances also are not considered The average detected concentrations of the remanning chemicals and radionucIIdes with $1 \times 10^{5}$ Ind PRGs exceedances are compared to their $1 \times 10^{5}$ Ind PRGs in the followng table

Avernge detected concentrations of analytes with Ind PRG exceedances compared to $1 \times 10^{3}$ Ind PRGs

\begin{tabular}{|c|c|c|c|c|}
\hline $\begin{array}{l}\text { Anatyte with } 1 \times 10^{3} \text { Ind } \\
\text { PRG exceedance(s) }\end{array}$ & $\begin{array}{l}\text { Number of } \\
\text { exceednaces }\end{array}$ & $\begin{array}{l}1 \times 10^{-5} \text { Ind } \\
\text { PRG }\end{array}$ & $\begin{array}{l}\text { Average detected } \\
\text { concentration }\end{array}$ & $\begin{array}{l}\text { Exceeds } 1 \times 10^{-3} \\
\text { Ind PRG? }\end{array}$ \\
\hline Arsenıc & 3 & $16 \mathrm{mg} / \mathrm{kg}$ & $855 \mathrm{mg} / \mathrm{kg}$ & No \\
\hline Iron & 1 & $100,000 \mathrm{mg} / \mathrm{kg}$ & $33,227 \mathrm{mg} / \mathrm{kg}$ & No \\
\hline $\mathrm{PCB}-1254$ & $i$ & $7400 \mathrm{ug} / \mathrm{kg}$ & $2166 \mathrm{ug} / \mathrm{kg}$ & No \\
\hline Polychlorinated biphenyl & 1 & $7400 \mathrm{ug} / \mathrm{kg}$ & $1504 \mathrm{ug} / \mathrm{kg}$ & No \\
\hline $\mathrm{Cs}-137$ & 1 & $113 \mathrm{pC} / \mathrm{g}$ & $0550 \mathrm{pCl} / \mathrm{g}$ & No \\
\hline Benz(a)antlracene & 1 & $21,096 \mathrm{ug} / \mathrm{kg}$ & 4452 ug $/ \mathrm{kg}$ & No \\
\hline Benzo(a)pyrene & 2 & $2110 \mathrm{ug} / \mathrm{kg}$ & $4259 \mathrm{ug} / \mathrm{kg}$ & Yes \\
\hline Benzo(b)fhoranthene & 1 & $21,096 \mathrm{ug} / \mathrm{kg}$ & $5024 u \mathrm{~g} / \mathrm{kg}$ & No \\
\hline
\end{tabular}

Only the average detected concentration of benzo(a)pyrene exceeds Its Ind PRG Therefore, benzo(a)pyrene is camed forward in the risk evaluation 
The next step in the nsk evaluation process is to recalculate the average concentranon of benzo(a)pyrene using the detected concentrations and pne-half the detection limt for non-detects and compare the recalculated average concentration to the $1 \times 10^{5}$ Ind PRG The recalculated average concentration of benzo(a)pyrene is shown in the followng table Analytacal resulis for which detecaon limils are not avalable bave been excluded from the calculation

Average contentration of benzo(a)pyrepe recalculated using detects and one-half the detection limit for non-detects compared to the $1 \times 10^{-5}$ Ind PRG

\begin{tabular}{cccc}
\hline & & Recalculaled average & EIceeds 1 $\times 10^{5}$ \\
Andyte & $1 \times 10^{-5}$ Ind PRG & $\begin{array}{c}\text { detected concentration" } \\
\text { Ind PRC? }\end{array}$ \\
\hline Benzo(a)pyreme & $2110 \mathrm{ug} / \mathrm{kg}$ & $1543 \mathrm{ug} / \mathrm{kg}$ & No \\
\hline
\end{tabular}

"The recaleulated average concentrabon is calculated ustng detected resuls and one-half the detechon limit for non-detects and does not inchude alabytical fesults where fetection limits are not avaslable

Thus, it is concluded that no undindual chemical or radionuclide will cause EU Z2-36 to exceed the I $\times 10^{4}$ nsk lumt of the Zone 2 ROD

The fraction of each average detected concentration relattive to the respective $1 \times 10^{5} \mathrm{~J}$ d PRG was calculated for all chemicals atd radionuclides with $1 \times 10^{3}$ Ind PRG exceedances, except for K-40, Ra-226, Th-228, Tb-230, and Th-232 Chemeals and radionuclides with undividual $1 \times 10^{5}$ lod PRG exceedances, the frachon of their average concentrations relative to ther respectuve $1 \times 10^{5}$ Ind PRGs, and the sum of fractions is shown in the following table

Chemicals and radionuclides with individual Ind PRG exceedances, their average detected concentration, and the fractlon of the average results relative to Ind PRGs

\begin{tabular}{|c|c|c|c|}
\hline Analyte & $\begin{array}{l}\text { Average detected } \\
\text { concentration }\end{array}$ & $1 \times 10^{-5}$ Ind PRG & $\begin{array}{c}\text { Result/Ind PRG } \\
\text { fraction }\end{array}$ \\
\hline Arsentc & $855 \mathrm{mg} / \mathrm{kg}$ & $16 \mathrm{mg} / \mathrm{kg}$ & 053 \\
\hline Iron & $33,227 \mathrm{mg} / \mathrm{kg}$ & $100,000 \mathrm{mg} / \mathrm{kg}$ & 033 \\
\hline PCB-1254 & $2166 \mathrm{ug} / \mathrm{kg}$ & $7436 \mathrm{ug} / \mathrm{kg}$ & 029 \\
\hline Polychlonnated biphenyl & $1504 \mathrm{~kg} / \mathrm{kg}$ & $7436 \mathrm{ug} / \mathrm{kg}$ & 02 \\
\hline Cs- 137 & $0550 \mathrm{pCl} / \mathrm{g}$ & $113 \mathrm{pC} / \mathrm{g}$ & 049 \\
\hline Benz(a)anthracene & $4452 \mathrm{ug} / \mathrm{kg}$ & $21,096 \mathrm{ug} / \mathrm{kg}$ & 021 \\
\hline Benzo(a)pyrene & $1543 u / \mathrm{kg}^{a}$ & $2110 \mathrm{ug} / \mathrm{kg}$ & 073 \\
\hline \multirow[t]{2}{*}{ Benzo(b)fluoranthene } & $5024 \mathrm{ug} / \mathrm{kg}$ & $21,096 \mathrm{ug} / \mathrm{kg}$ & 024 \\
\hline & & Sum of fractions & 3.02 \\
\hline
\end{tabular}

'Resalculated using detected results and one-half the detection bmit for won-detects

For EU Z2-36, the sum of fractions is 302 , whuch is significantly less than the 75 sum of fractions benchmark for evaluatung the need for a quantilative nsk assessment ( $1 \mathrm{e}$, approximately $75 \%$ of the $\mathrm{J} \times 10^{4}$ Ind PRGs) Therefore, it is conciuded the cotnbyed unpact of all Ind PRG exceedances will not cause EU Z2-36 to exceed the I $\times 10^{4} \mathrm{rask}$ lumit of the Zone 2 ROD

Threat to groundwater The threal to groundwater from ant EU is evaluated by looking at MCL exceedances in local groundwater wells and comparing the chemicals and radionucljdes wth MCL exceedances to chemcals and radionuchdes with GW SL exceedances If there are matches between the two sets of analytes, then the mobilites of the matching analytes are evaluated, the wolumetnc extent of theur GW SL exceedances are esturnated, and a conclusion is drawn regarding whether any of the inatching analytes is a source of groundwater contamination

As discussed in Sec1 225 , there have been a substantal number of hisloncal VOC MCL exceedances actuss the EU However, the sources of VOC contamination have been identufied as being located outside of the EU and there are no GWSL exceedances in soll samples collected from EU Z2-36 Therefore, it is concluded that solls in EU Z2-36 do not pose a threat to groundwater 
Onglitatuve rusk screempe for unrestructed use There is a low probability that the acreage of EU Z2-36 couId be released with no land use restrictions There is one location with two PCB AVt RL exceedances that will reman because the exceedances do not cause the average concentrations across the EU to exceed the Avg RL, and there are widespread Ind PRG exceedances and resıdental PRG exceedances An appropnate evaluation of residental risk should be conducted to make a definituve conclusion regarding unrestreted use

\section{Zane 2,ROD Appendix A EFA Sites}

Based on sampling analytical results at the EU Z2-36 FFA Sites (Sect 225 and 226 ) and an evaluation of the EUf-wide contammant profile (above), solls in the following Zone 2 ROD Appendix A FFA site do not pose a potentual threat to the industral worker

- K-1098-C Asphalt Plant FFA Site

- K-1503 Neutralızation Pit FFA Site

\begin{tabular}{|l|l|}
\hline 4.0 & RECOMMENDATION FOR ACTION/NO FURTHER ACTION \\
\hline 4.1 & DECLSION AND REMEDIATION ACTIVTIES \\
\hline
\end{tabular}

EU Z2-36: Based on analytical results of DVS and historcal semples collected in EU Z2-36 and the Class 3 SU walkover assessment in the EU, the U S Department of Energy (DOE) recommends that NFA is approprate for the 15 acres of the EU

Based on the existence of known groundwater contamunant plumes beneath EU 22-36, DOE does not recommend the 10-ft-depth land use restriction be lifted trom the EU

FFA Sites: Based on sampling analytical results and the recommendation for EU Z2-36, DOE recommends NFA as appropnate for the following FFA sites

- K-1098-C Asphalt Plant FFA Site

- K-1503 Neutralization Pat FFA Site

\begin{tabular}{l|l}
\hline 4.2 & EXCAVATION ACTIVTIES/CONFIRMATION SAMPLING
\end{tabular}

None 


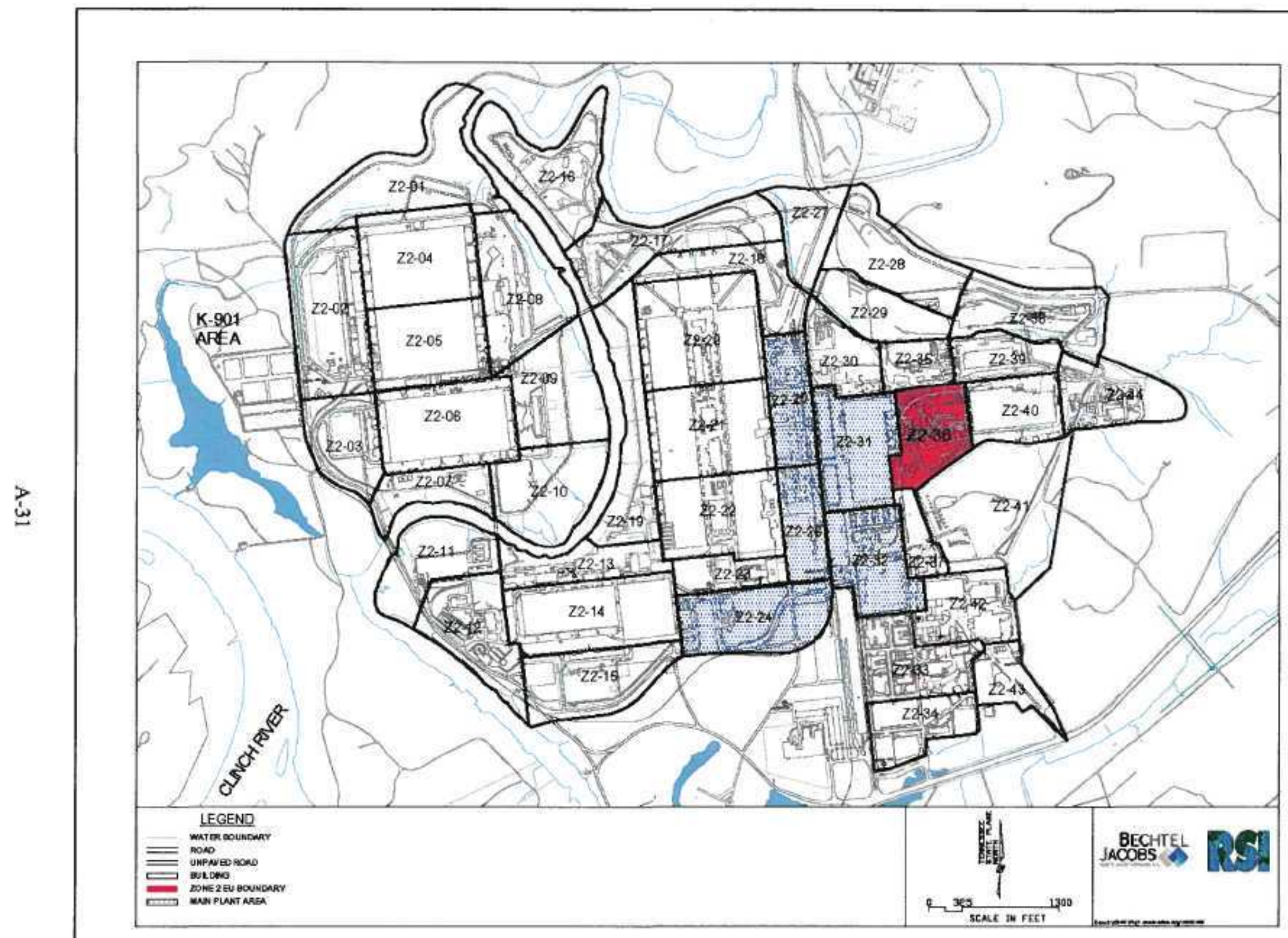

Fig. A.1. EU Z2-36 location map. 


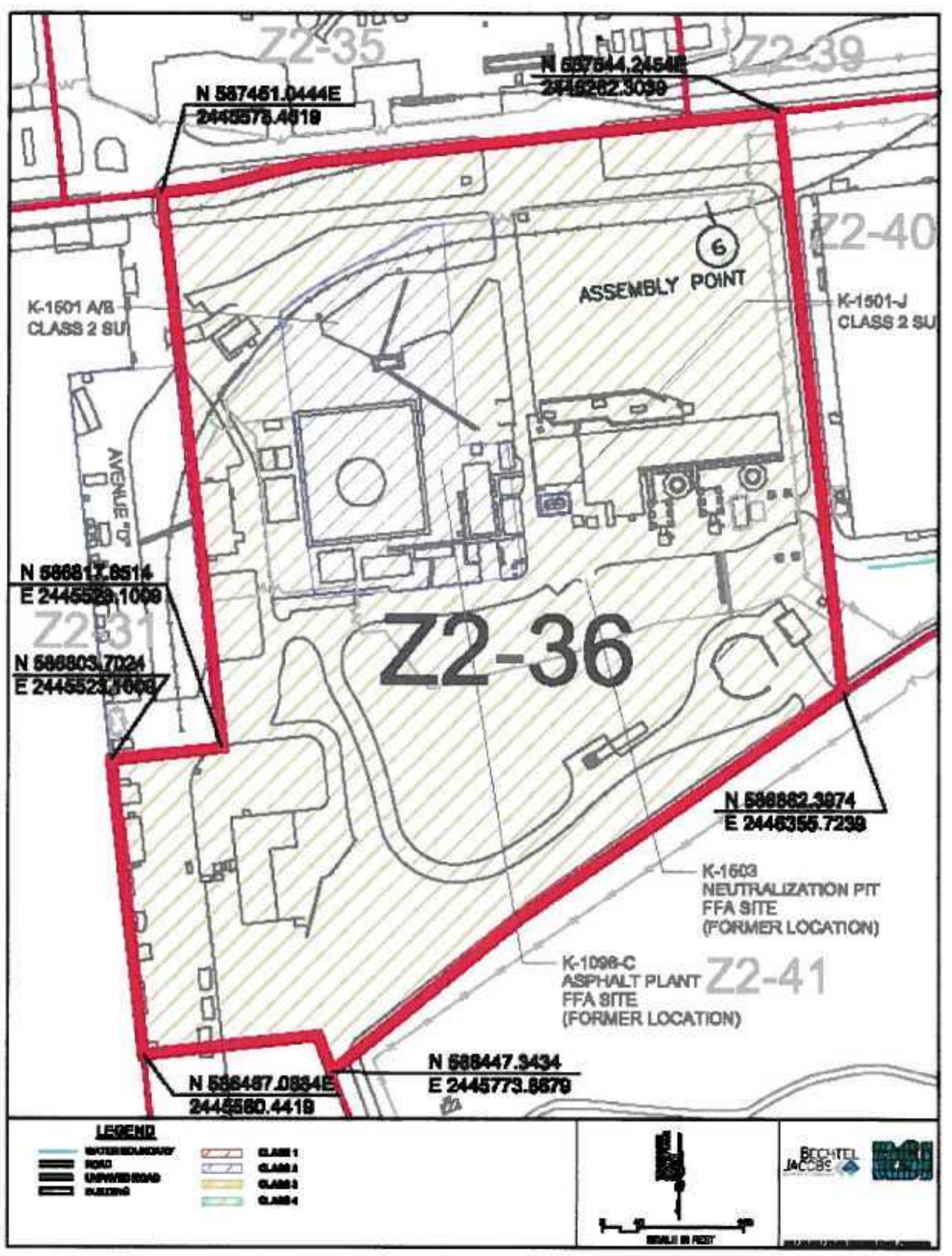

Fig. A.2. EU Z2-36 boundary location map. 


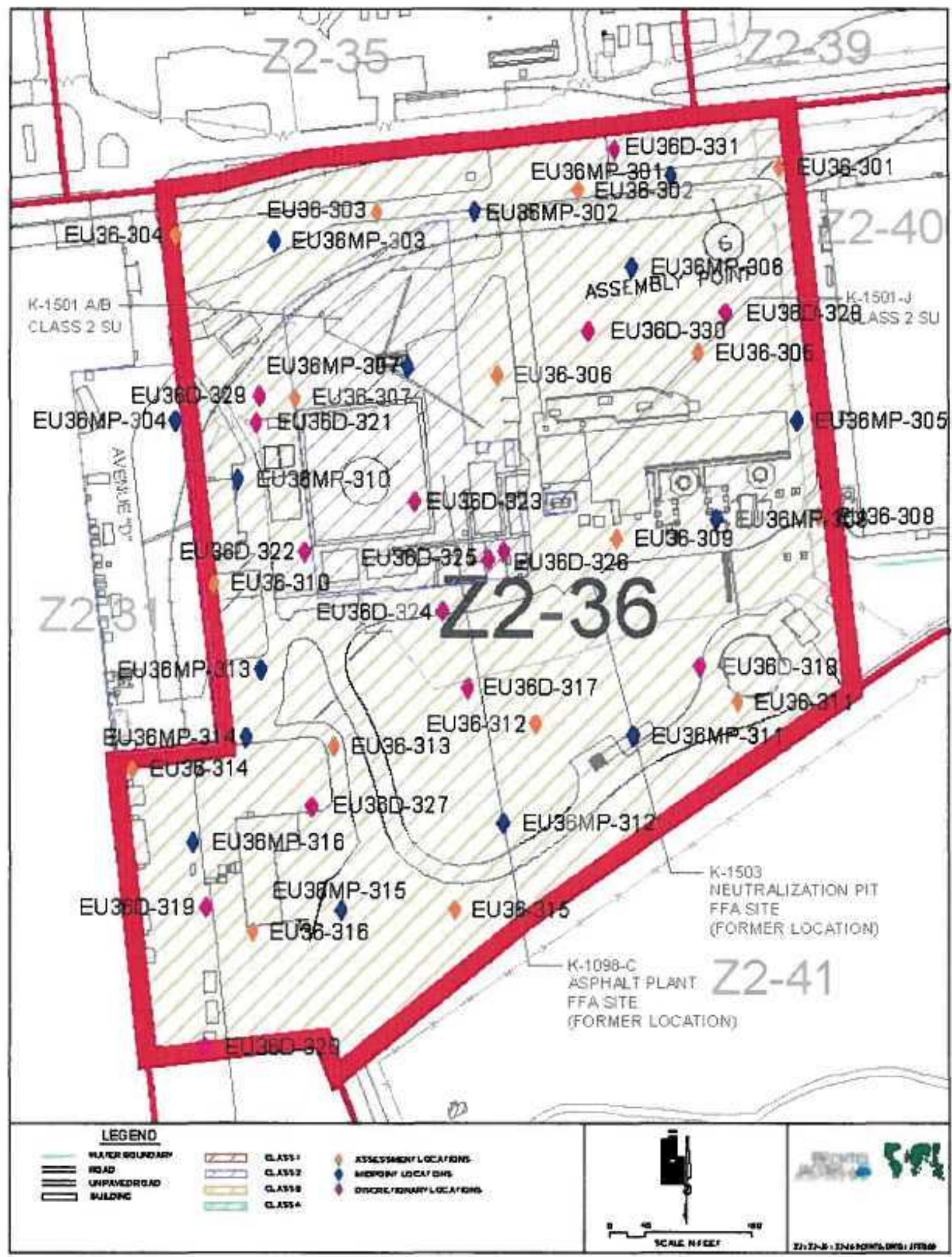

Fig. A.3, EU Z2-36 area field map. 


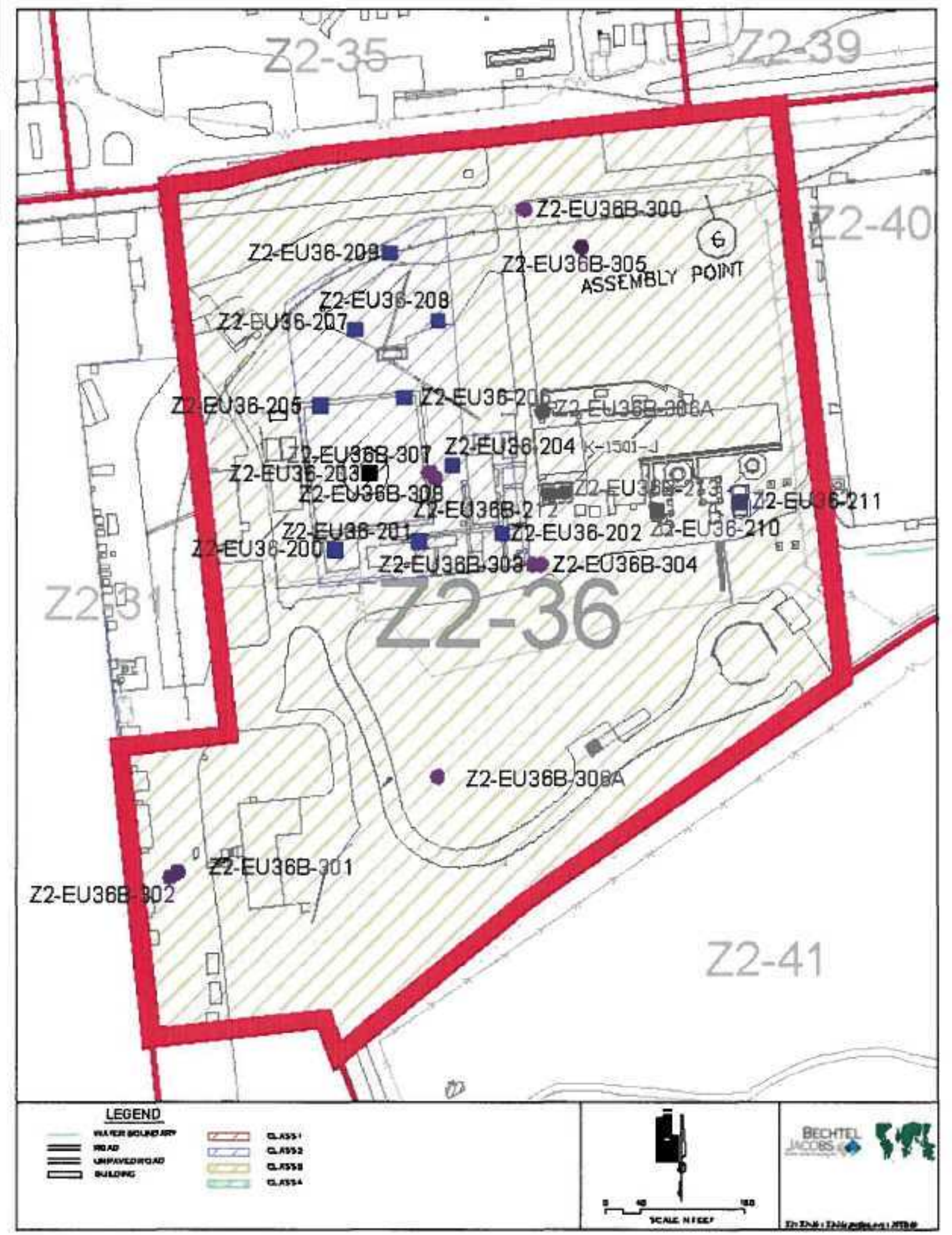

Fig. A.4. EU Z2-36 sample locations. 
Table A.1. EU 22-36 facility and FFA site list

\begin{tabular}{|c|c|c|c|}
\hline \multirow[b]{2}{*}{ Facility name DQO scoping } & \multicolumn{2}{|c|}{ Fańlity assessed? } & \multirow[b]{2}{*}{ Comments } \\
\hline & Yes & No & \\
\hline $\begin{array}{l}\mathrm{K}-1045-C \text { Steam Plant Operator Office (was K-1045-B } \\
\&-\mathrm{C} \text { ) }\end{array}$ & $\mathrm{X}$ & & Concrete slab \\
\hline K-1098 Marnterarce Shop and Storage & $\mathrm{x}$ & & Contrete slab \\
\hline K-1098-C Asphali Plant & $\mathrm{X}$ & & Also evaluated as a FFA site \\
\hline K-1098-E Heal Treat Facility & $\mathrm{x}$ & & \\
\hline K-1204-0S Sewage Ejector Station & $\mathrm{x}$ & & \\
\hline K-โ3เ0-BJ & $\mathrm{x}$ & & \\
\hline K-1310-BM OMI Mantenance Office and Breakroom & $\mathrm{x}$ & & \\
\hline K-I3IO-DD & $\mathrm{x}$ & & \\
\hline K-13]0-DJ & $\mathrm{x}$ & & \\
\hline K-1310-JH & $\mathrm{X}$ & & \\
\hline $\mathrm{K}-1310-\mathrm{KC}$ & & $\mathrm{X}$ & Trailer has been removed \\
\hline $\mathrm{K}-1310-\mathrm{KD}$ & $\mathrm{x}$ & & \\
\hline K-1310-KK & & $\mathrm{x}$ & Trailex has been removed \\
\hline $\mathrm{K}-\mathbf{I}\} \mathbf{1 0 - K L}$ & & $\mathrm{x}$ & Traller has been removed \\
\hline $\mathrm{K}-1310-\mathrm{KM}$ & & $\mathbf{X}$ & Traller has been removed \\
\hline K-1400 Office Buldung & $\mathrm{x}$ & & \\
\hline $\mathrm{K}-1420-\mathrm{D}$ & $\mathrm{x}$ & & \\
\hline K-1423 Grease Burıal Site & & $\mathrm{x}$ & FFA sile located in EU Z2-25 \\
\hline K-1501/K-1501-B Steam Plant & $\mathrm{X}$ & & \\
\hline K-I 50l-A On] Storage Tank & $\mathrm{x}$ & & Concrele slab \\
\hline K-1 Sol-B Ol Storage Tank & $\mathrm{x}$ & & Concrete slab \\
\hline K-1501-C Foam House & $\mathrm{x}$ & & Concrete slab \\
\hline K-1501-D Ol Unloading Station & $\mathrm{x}$ & & \\
\hline K-1501-E Coal Crusher and Unloading Statuon & $\mathrm{x}$ & & \\
\hline K-1 501-F Conveyor Stalion & $\mathrm{x}$ & & Concrete slab \\
\hline K-1501-G Sulfuric Acid Storage Tank & $\mathrm{x}$ & & Concrete slab \\
\hline K-1501-H Mantenance Facility & $\mathrm{x}$ & & \\
\hline K-1501-J Fuel Storage Tenk & $\mathrm{x}$ & & Concrete slab \\
\hline K-1501-K, PCB Un]pading Station & $\mathrm{x}$ & & Concrete slab \\
\hline K-I50l-L Instrument Maintenance Shop & $\mathrm{X}$ & & \\
\hline K-L50l-N Gress Covered Coal Storage Yard & $\mathrm{x}$ & & \\
\hline K-1501-P1 Buel Electrostatic Precjpitator & $\mathrm{X}$ & & \\
\hline K-1501-P2 Buel Electrostallc Precipitalor & $\mathrm{x}$ & & \\
\hline K-1501-Q Electncal Storage Shop & $\mathbf{x}$ & & Concrete slab \\
\hline K-1501-S Coal \$torage Yard (South) & $\mathrm{x}$ & & \\
\hline K-1501-\$1 Brick Stack & $\mathbf{x}$ & & \\
\hline K-I501-S2 Bnck Stack & $\mathrm{x}$ & & \\
\hline K-lSol-T Brıne Salt Tank & $x$ & & Concrete slab \\
\hline K-I501-U Sulfunc Acad Tark & & $\mathrm{X}$ & Tank has been removed \\
\hline K-1501-V Equipment Storage & $x$ & & \\
\hline K-1503 Neutralization Pit & $\mathrm{x}$ & & Also evaluated as a FFA site \\
\hline K-1534 Gas Valve Shelter & $\mathrm{x}$ & & \\
\hline $\mathrm{K}-1028-84$ & $x$ & & Guard shack \\
\hline K-1310-FW & $\mathrm{x}$ & & Change house traler \\
\hline K-1310-GS & $\mathrm{x}$ & & OMI office traller \\
\hline $\mathrm{K}-1501$ & $\mathrm{X}$ & & Staging area \\
\hline K-150l-W & $\mathrm{X}$ & & OMI maintenance shop bulding \\
\hline $\mathrm{K}=1501-\mathrm{K}$ & $x$ & & Metal compressor bulldıng \\
\hline K-1501-Y & $\mathrm{x}$ & & Metal compressor building \\
\hline $\mathrm{K}-1501-Z$ & $\mathrm{x}$ & & Maintenance storage bulding \\
\hline K-700-A-67 & $\mathrm{x}$ & & Transformer substatson \\
\hline
\end{tabular}

$\mathrm{DQO}=$ daca qualiy objective $\quad F F A=$ Fedetal Facilly Agreejnent

EU = exposure nort 
Tabble A 2. EU Z2-36 sanaple sumnoary

\begin{tabular}{|c|c|c|c|c|c|c|c|c|c|c|c|c|c|c|c|}
\hline \multirow[b]{2}{*}{ su } & \multirow[b]{2}{*}{$\begin{array}{l}\text { Datc } \\
\text { spepict } \\
\end{array}$} & \multirow[b]{2}{*}{ Lexteten 1 ll. } & \multicolumn{2}{|c|}{ Loredenten } & \multirow[b]{2}{*}{ Sigmple Interval } & \multicolumn{2}{|c|}{ Sersonter } & \multicolumn{7}{|c|}{ OAft-tile baberatery } & \multirow[b]{2}{*}{ Compente 2nd molsh } \\
\hline & & & Embtr. & Nerlliv: & & PuR & voc & Molu|s & PCE & RAn & swor. & voc & Orther & 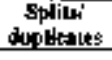 & \\
\hline \multicolumn{16}{|c|}{ DVS sampie iousuluta } \\
\hline 2 & or/Is & 22-EU36M-200 & 2445728 & sintil & D-10 \& 3 motrual compasile & $\mathrm{i}$ & $T$ & $\mathbf{T}$ & $T$ & & $T$ & & & & 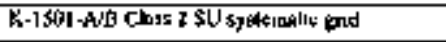 \\
\hline$\frac{2}{2}$ & OT/ISNO & 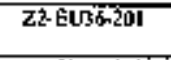 & 2445868 & $59 \pi 041$ & 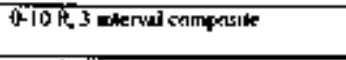 & $i$ & $T$ & $T$ & $T$ & $T$ & $T$ & $T$ & $T$ & & 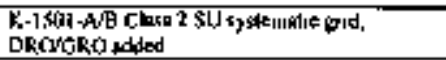 \\
\hline$\overline{2}$ & $00 / 1 \sin (0)$ & 27 -EU36-202 & $24+5 * 64$ & $58 \sin ^{2} 0$ & 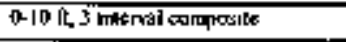 & $\mathbf{i}$ & $T$ & $\mathbf{T}$ & $T$ & & $T$ & & & D & 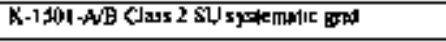 \\
\hline$\overline{2}$ & 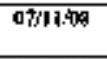 & Z3-EUS6-2013 & 2445811 & $58710^{\circ}$ & 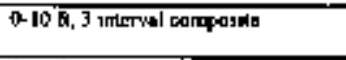 & $T$ & $T$ & $T$ & $\mathrm{l}$ & & $T$ & $T$ & $T$ & & 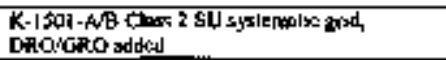 \\
\hline 2 & $60 / 496$ & $22-E U 36-204$ & 244590T & $\$ 87124$ & 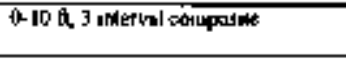 & $T$ & $T$ & $\mathbf{i}$ & $T$ & $T$ & $T$ & $\bar{T}$ & T & & 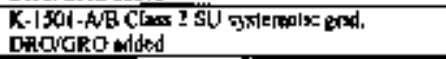 \\
\hline 2 & $07 / 1900$ & 2 2-EUJ36-205 & 2445755 & 587908 & 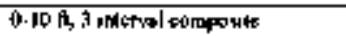 & 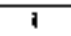 & $T$ & 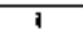 & $T$ & & $T$ & & & & K. \\
\hline 2 & 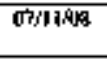 & Z2-EU76-206 & 2445851 & 597203 & 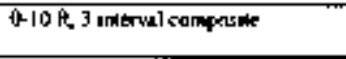 & $\mathbf{T}$ & $T$ & $\mathbf{i}$ & $T$ & $T$ & $T$ & $\mathbf{I}$ & $\mathrm{T}$ & & 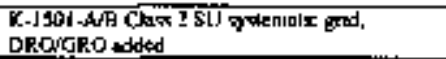 \\
\hline$\overline{2}$ & 0700993 & 22-EUJ6M-E0T & $2 \operatorname{sis} 3 \overline{9}$ & 59774 & 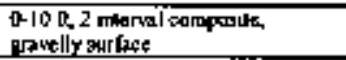 & $\mathbf{i}$ & $T$ & $\mathbf{I}$ & $T^{\prime \prime}$ & & $T$ & & & & 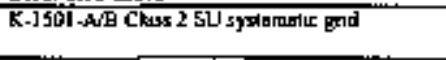 \\
\hline$\overline{2}$ & 07700906 & Z2.EU36. 209 & 2445890 & 5KTh95 & 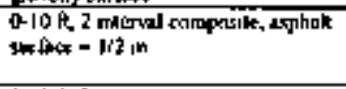 & $\mathrm{T}$ & 1 & $\mathbf{T}$ & 1 & & T & $\mathbf{T}$ & $T$ & & 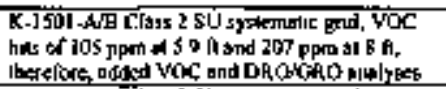 \\
\hline$\overline{2}$ & DTNAYW & 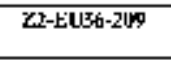 & $245 \% 34$ & 987374 & 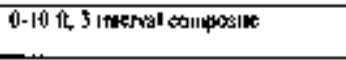 & $T$ & $T$ & $T$ & 1 & $\mathbf{i}$ & $\mathbf{i}$ & $T$ & 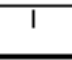 & & 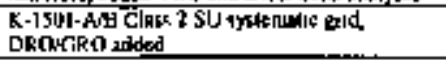 \\
\hline 2 & Drosinger & 2I-EL46-21D & 246145 & 587076 & 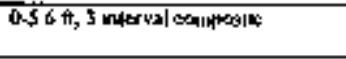 & $T$ & $T$ & $T$ & $T$ & $T$ & 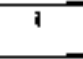 & $T$ & $T$ & & 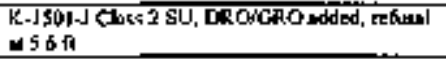 \\
\hline 7 & $07 / 6000$ & 22-EU36-2II & 2406239 & 5月1006 & 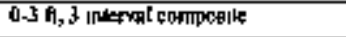 & $T$ & $\mathrm{~T}$ & $\mathrm{~T}$ & $\mathbf{T}$ & & $\mathbf{T}$ & & & & K-ISU|-J Ches 2 SU \\
\hline 7 & 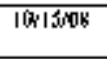 & $2 z-E U J(B-212$ & 2446018 & Iאत09 4 & 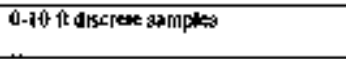 & $T$ & $T$ & & & & & & & & 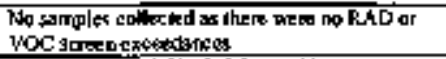 \\
\hline 2 & IQISTNA & 22-FIJakA-2|a & 246035 & $58 \% 972$ & T.75 R discetere samples & $T$ & $T$ & & & & & $\mathbf{T}$ & & & 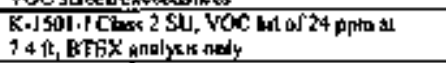 \\
\hline 3 & & 22.5U961-506 & 2409960 & $5 \bar{B} 7424$ & 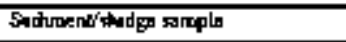 & & & & & & & & & & 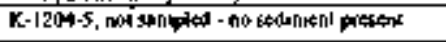 \\
\hline 3 & काषेत्य & 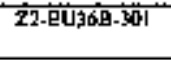 & $2 A+3191$ & 586559 & Sedrocent stmplo & & & T' & $T$ & T & $T$ & $T$ & & & 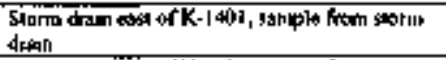 \\
\hline 3 & D7/16KOE & 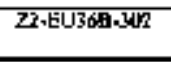 & 2445582 & SE6553 & 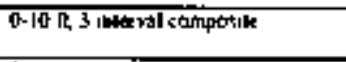 & $T$ & $\mathrm{~T}$ & T & $T$ & & $T$ & & & & 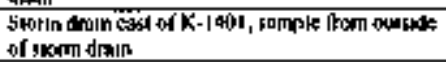 \\
\hline 3 & OFIAXOR & 22-PU969-303 & 2915999 & SRTOIA & Sedment sampins & & & $\mathrm{T}$ & $T$ & $\mathbf{T}$ & $\mathbf{T}$ & $T$ & & & 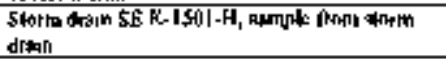 \\
\hline 3 & $97 / 606$ & Z2.EU36B-3604 & 2406009 & 1k7014 & 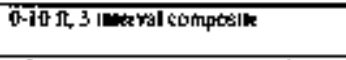 & $\mathrm{T}$ & 1 & $T$ & $T$ & & $\mathbf{i}$ & & & & 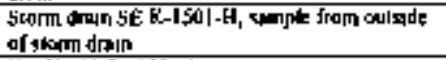 \\
\hline 蓜 & 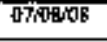 & Z72.EU36B. 305 & $2+46055$ & 467360 & 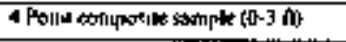 & 1 & 1 & 1 & $i$ & & 1 & & & & K-ISIII-N S.ool Yord \\
\hline 3 & DrMatas & 72.Eบ366.8264 & 74t5BS9 & 386769 & 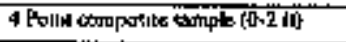 & $\mathbf{I}$ & $\mathbf{i}$ & 1 & $\mathbf{i}$ & & $\mathbf{i}$ & & & & 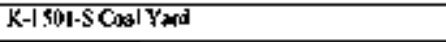 \\
\hline 3 & Q7WhÓK & 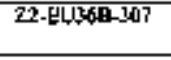 & 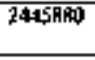 & 383120 & 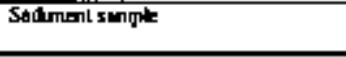 & & & $T$ & $T$ & $\mathbf{T}$ & $T$ & $\mathrm{~T}$ & & & 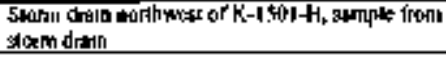 \\
\hline
\end{tabular}


Tabta A.々 EU Z2-36 sampte summary (cont)

\begin{tabular}{|c|c|c|c|c|c|c|c|c|c|c|c|c|c|c|}
\hline \multirow{2}{*}{$\begin{array}{c}\text { St' } \\
\text { chiss }\end{array}$} & \multirow[b]{2}{*}{$\begin{array}{c}\text { Callo } \\
\text { samilog }\end{array}$} & \multirow[b]{2}{*}{ Loctwot ID } & \multicolumn{2}{|c|}{ Lecotion } & \multirow[b]{2}{*}{ Sanple lakcrinl } & \multicolumn{2}{|c|}{ Serrecine } & \multicolumn{7}{|c|}{ 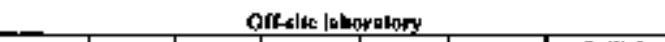 } \\
\hline & & & Euplurg & Martelinx & & RAD & Voc & MJenath & $\mathrm{PCE}$ & RAO & swox: & $\mathrm{vec}$ & OAther & 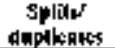 \\
\hline 3 & 0779502 & $270168-30 \mathrm{~B}$ & 2455986 & 58714 & $0-10$ fh, 3 I Ine & 1 & $\mathrm{l}$ & 1 & 1 & & $\mathrm{I}$ & & & \\
\hline 3 & 413007 & $22-2016 \mathrm{~B}-310$ & 2446010 & $587 \mid 9]$ & 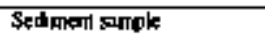 & & & 1 & $\mathbf{T}$ & l & $\mathbf{T}$ & $T$ & $\mathbf{T}$ & \\
\hline & & & & & 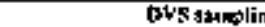 & 19 & ]9 & 2j & 21 & 5 & 31 & 12 & & 8 \\
\hline
\end{tabular}

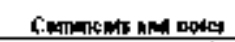

1-h, smmint tram

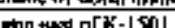

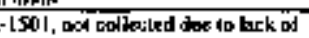

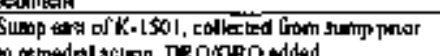

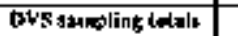

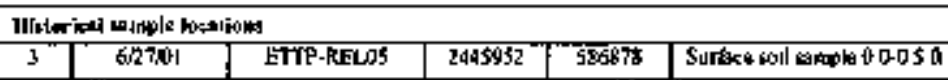

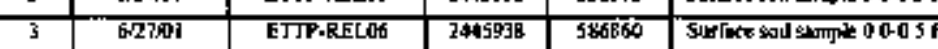

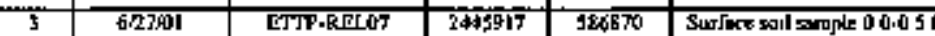

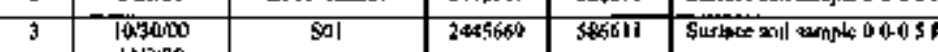

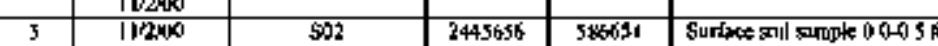

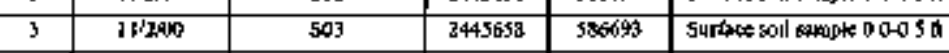

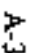

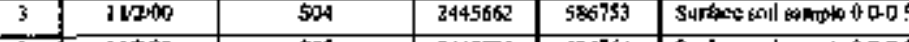

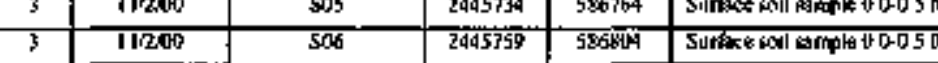

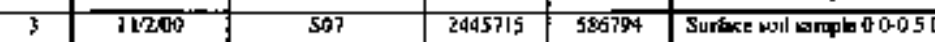

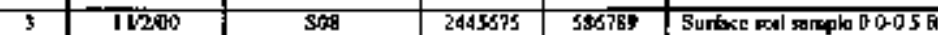

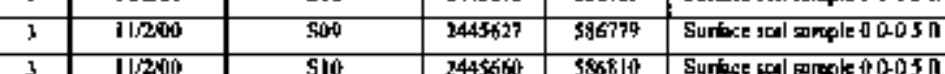

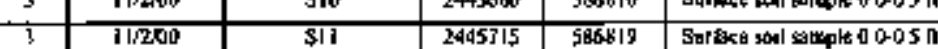
Hds arketi sampling iewsis

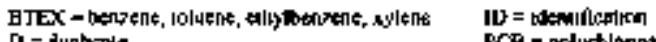

DRO Juntwe

T.1

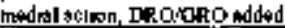

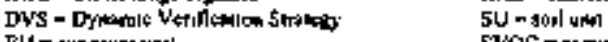

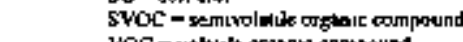

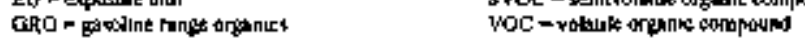




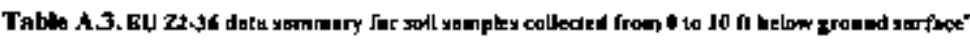

\begin{tabular}{|c|c|c|c|c|c|c|c|c|c|c|c|c|c|}
\hline$-\quad$ sul & $\begin{array}{l}\text { Frequetocy } \\
\text { of delect }\end{array}$ & 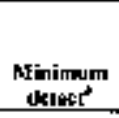 & $\begin{array}{c}\text { Maximsin } \\
\text { Melest }\end{array}$ & 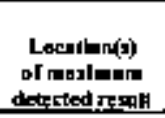 & 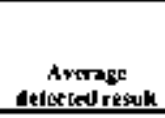 & $\begin{array}{c}\text { Moxinum } \\
\text { RL } \\
\end{array}$ & $\begin{array}{l}\text { Frequency } \\
\text { of doterts } \\
\text { escoeding } \\
\text { maxkroum RL }\end{array}$ & $\begin{array}{c}\text { Aserage } \\
\text { BL }\end{array}$ & $\begin{array}{l}\text { Freqwarky } \\
\text { of dotrelf } \\
\text { esecedilos } \\
\text { ererace RL }\end{array}$ & 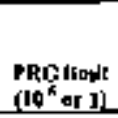 & 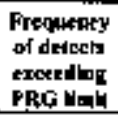 & 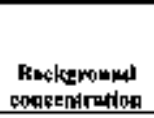 & 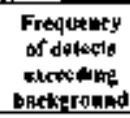 \\
\hline \multicolumn{14}{|l|}{ 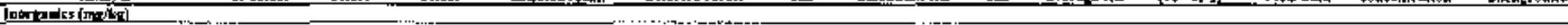 } \\
\hline Alumamm & $26 / 24$ & 1,400 & 24,000 & $72-\mathrm{EU}(36-202$ & $13, \alpha_{1}^{2}$ & & $\mathrm{NA}$ & & $\mathrm{NA}$ & 100,000 & $a / 26$ & 40,300 & 026 \\
\hline Amimony & $21 / 24$ & 0016 & $24 \mathrm{~J}$ & 22-EUSC: -510 & 0338 & & $N_{A}$ & & $\mathrm{NA}$ & 40018 & 026 & 152 & $2 / 26$ \\
\hline Asence & $25 / 26$ & 097 & 37 & 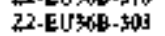 & 855 & 900 & o/26 & 500 & $0 \times 26$ & 159 & $1 / 26$ & 1495 & $3 / 26$ \\
\hline Burtam & $30 / 26$ & 47 & 260 & $27-E U 3 \times 60-, 013$ & 113 & & $\mathrm{NA}$ & 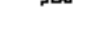 & $\mathrm{NA}$ & $6,5 n$ & $1 / 26$ & 12493 & $7 / 26$ \\
\hline Eorylhum & $25 / 26$ & 04,5 & 17 & Z2-FU36-205 & 10 & 8,000 & 0,26 & 2,1000 & 0,26 & $1,94]$ & $\ln 6$ & 22 & $0 / 6$ \\
\hline Borten & $2|z|$ & 028 & 20 & $72-6036 \mathrm{~B}-301$ & 432 & & $\mathrm{NA}_{\mathrm{A}}$ & & $N_{A}$ & 100,000 & and & & NA \\
\hline Codroum & $\sin 20$ & 01 & 468 & Sol & 0634 & & $\mathrm{NA}$ & & NA & $45]$ & N 216 & 022 & $16 / 26$ \\
\hline Calcmam & 26126 & 1,400 & 250,000 & 22-EU136-209 & 42315 & & NA & & NA & & $N A$ & 2,400 & $22 / 26$ \\
\hline Chrompuna & 2626 & $9 \mathrm{RBJ}$ & 160 & 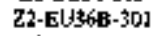 & 356 & & $N_{A}$ & & $\mathrm{~N}_{\AA}$ & 640 & $0 / 26$ & 4486 & $7 / 26$ \\
\hline $\cos a a^{\prime}$ & 2626 & 35 & $2 a$ & Z2-EUBG-2II & 151 & & NA & & $N A$ & 133,310 & 016 & 42 & 026 \\
\hline copper & 2626 & If & 931 & sin & 79 & & NA & & $\mathrm{N}_{A}$ & 44,977 & 126 & 2240 & zonits \\
\hline Inot & $26 / 26$ & 8.600 & 140,000 & Z2-E1336-3-303 & 33,227 & & NA & & $\mathrm{NA}$ & 1000000 & $1 / 26$ & 56,600 & 1126 \\
\hline Land & 26276 & 79 & 390 & 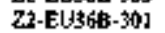 & 4) | & & $\mathrm{NA}$ & & $\mathrm{NA}_{A}$ & $B O D$ & 076 & $\$ 791$ & $6 / 26$ \\
\hline LnImum & $2 \sqrt{2}]$ & 63 & 35 & Z22-EUYGB-306 & (A) 1 & & $\mathrm{NA}$ & & $N A$ & 20,439 & 0.21 & 4394 & a.2] \\
\hline afagoveswou & $26 \sqrt{26}$ & 1813 & 65,000 & Z2-EUX6B-501 & 12,084 & & $N A$ & & $N A$ & & $N A$ & 3,300 & jyiat \\
\hline Nemporicas & $26 / 26$ & 900 & 4,200 & $22-\mathrm{E} J 36 \mathrm{E}-50\}$ & $1,0] 0$ & & $\mathrm{NA}$ & & $\mathrm{NA}$ & 39,458 & 026 & $2,20,1$ & $1 / 26$ \\
\hline NAcectury & $29 / 26$ & (1) 0161 & 1985 & s01 & OH $15 \mathrm{~B}$ & 1,800 & 0,26 & 600 & 0,26 & 307 & now & 017 & $3 / 26$ \\
\hline Molybolswipla & $|\pi / 2|$ & 016 & 65 & 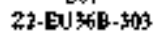 & 174 & & $\mathrm{NA}_{\mathrm{A}}$ & & $\mathrm{Nh}$ & 1,110 & 0/2 & & $\mathrm{NA}$ \\
\hline Nuston & $26 / 26$ & is & 613 & \$\$O| & 119 & & $N \lambda$ & & $\mathrm{NA}$ & 20,439 & 026 & 2607 & 20626 \\
\hline Potansinatra & $26 / 26$ & 370 & $3,5 \%$ & 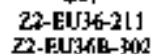 & 1972 & & $N_{A}$ & & $\mathrm{NA}$ & & NA & 5,079699 & $\sqrt[a]{26}$ \\
\hline Solenumm, & $3: 26$ & 0.3223 & 3 & Z2.EU368. 310 & 163 & & $\mathrm{~N} \hbar$ & & $\mathrm{Nh}$ & 5,110 & 026 & $1+7$ & 526 \\
\hline Sillwer & 5.26 & 0002 & 085 & 301 & 042 & & NA & & $\mathrm{NA}$ & 5,110 & $0 / 26$ & 06 & $2 / 20$ \\
\hline Solum & 2220 & 394 & 2901 & 22-EL360-310 & $17 y$ & & NA & & NA & & Nh & 497 & 426 \\
\hline Thalsurn & $2] / 26$ & 0043 & $054 \mathrm{~J}$ & Z7-EUS6E-3LO & 0217 & & $\mathrm{NA}$ & & $N_{A}$ & 675 & an 26 & 04 & 1/26 \\
\hline Uг্вичи & $21 / 21$ & $03 \mathrm{~B}$ & 47 & Z2- EWYGG - 305 & 146 & & NA & & $\mathrm{NA}$ & 204 & 0,21 & & $N_{A}$ \\
\hline Yopdum & 30,26 & 66 & 56 & 22.EU36-210 & 264 & & NA & & $N A$ & 1,002 & 026 & 6147 & 126 \\
\hline 2 mat & $26 / 26$ & 23 & 396 & 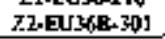 & 粗B & & NA & & $\mathrm{NA}$ & 100,000 & $0 / 26$ & 897 & {$[/ 26$} \\
\hline \multicolumn{14}{|l|}{ 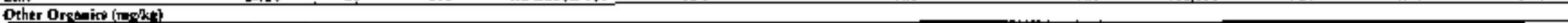 } \\
\hline Dwroal Aangy Organics & $\overline{3 / 8}$ & 52 & $\$ 60 \mathrm{~J}$ & Z2-EUT-6-20:8 & 342 & & NA & & $\sqrt{n}$ & & WA & & w $\Omega$ \\
\hline 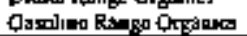 & $4 \pi$ & U烦 & 25 & Z2-EUT6-2008 & 736 & & NA & & $\mathrm{NA}$ & & WA & & NA \\
\hline \multicolumn{14}{|c|}{ 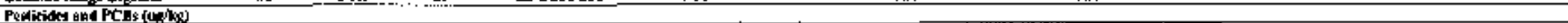 } \\
\hline $\operatorname{PCD}-10] 6$ & 0,27 & NE & ND & & ND & 10000 & 0,27 & 10,000 & क्2 & $\overline{37,000}$ & 027 & & WA \\
\hline PCE.|221 & anz & NE & ND & & No & 100,000 & ait & 10,000 & w2t & 0,436 & 027 & & HA \\
\hline PCB.1232 & 0,27 & $\mathrm{NE}$ & ND & & No & 100000 & $0 \times 7$ & 10,000 & 0,27 & 3,430 & 027 & & $\mathrm{NA}$ \\
\hline RCE- 1242 & $a / 27$ & NE & ND & & ND & ionotono & an? 7 & 10,000 & and7 & 7,436 & $a b 3$ & & $\mathrm{NA}_{\mathrm{A}}$ \\
\hline RCE-12018 & 027 & $\mathrm{NE}$ & ND & & ND & 1000000 & w27 & 10,000 & w/27 & 7,436 & 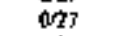 & & NA \\
\hline$P C 9-1254$ & $\sin$ & $8 \|$ & 16,000 & $22-E N 360-301$ & 2166 & 100,000 & 027 & 10,000 & $1 / 27$ & 7,436 & $1 / 23$ & & NAA \\
\hline $109-1260$ & $11 / 27$ & Jij & 249 & 501 & 586 & 100,000 & 0,27 & 10,000 & 0N27 & 7,436 & $\omega_{23}$ & & NA \\
\hline Potychlorillosed luphesw| & $|n|$ & R I I & 10,0100 & $72-E(\{36 \mathrm{~B}-90]$ & 1,504 & 100000 & $0 / 2]$ & 10,000 & $1 / 2]$ & 7,436 & $|/ 2|$ & & NA \\
\hline \multicolumn{14}{|l|}{ 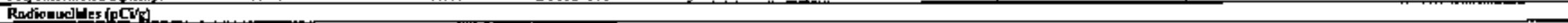 } \\
\hline 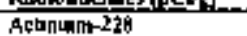 & $4 / 4$ & 0862 & $144 J^{\prime \prime}$ & $22 . E(536-2006$ & 1228 & & NA & & $\mathrm{NA}$ & {$[1,900$} & $0 / 4$ & & $\overline{N A}$ \\
\hline Alphd acigunty & 9 & 320 & 101 & $Z 7 . E U S 60.204$ & 662 & & NA & & $N A$ & 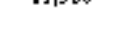 & $N_{A}$ & & NA \\
\hline Almy nomr 26 & 称 & ND & No & & mo & & NA & & $N_{A}$ & 016 & ני & & $\mathrm{WA}$ \\
\hline Amost Helurt-24] & $1 / 2$ & 0) 123 & 0123 & 501 & 0173 & & NA & & $\mathrm{N} \lambda$ & st & 02 & & NA \\
\hline Dasyllhan-7 & {$[/]$} & 2931 & 2933 & $Z 2-E U{ }^{3}-6 B-30 T$ & 295 & & NA & & $\mathrm{NA}$ & 1,200 & a $]$ & & HA \\
\hline Datas scurity & $y / y$ & 303.3 & 353 & $22-E \cup 136-204$ & 589 & & $N_{A}$ & & $\mathrm{~N} h$ & & $w_{A}$ & & NA \\
\hline Batoriat-214 & $1 / 4$ & $0 \quad 0<6$ & $134]$ & $22-E-U 36-10$ & 106 & & $\mathrm{Nh}$ & & $\mathrm{Nh}$ & $134,0 \times 10$ & 014 & & NA \\
\hline
\end{tabular}


Tabte A J. (conthued)

\begin{tabular}{|c|c|c|c|c|c|c|c|c|c|c|c|c|c|}
\hline Antolizite & $\begin{array}{l}\text { Friqumaty } \\
\text { ordetestr }\end{array}$ & 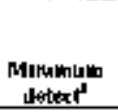 & 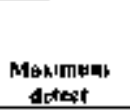 & 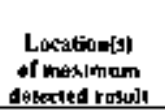 & 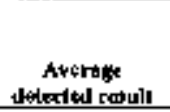 & $\begin{array}{l}\text { Makmwith } \\
\mathrm{RL}\end{array}$ & 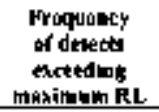 & Atarabe & 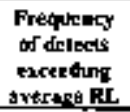 & 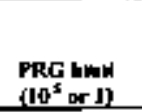 & 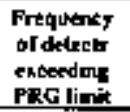 & $\begin{array}{l}\text { Buckgrosend } \\
\text { cecentritim }\end{array}$ & 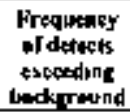 \\
\hline 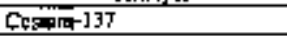 & 12234 & 011 & 124 & SDI & 0550 & 20 & $0 / 24$ & 2 & 0,24 & $\frac{113}{13}$ & 2224 & & NA \\
\hline Cotbille-56 & $a l$ & No & Nn & & ND & & NA & & NA & & $N_{A}$ & & $\mathrm{NA}$ \\
\hline $\operatorname{cotan} 1-\infty \theta$ & $3 n 1$ & $0.0045 t$ & 000053 & $\$ 10$ & 0008 & & NA & & NA & 06 & $0 / 25$ & & $N A$ \\
\hline $\operatorname{Lis}_{\Delta \rightarrow 212} 212$ & 3 & 0676 & 168 & Z2-EUड*-210 & 123 & & $\mathrm{NA}_{\mathrm{A}}$ & & NA & 61,300 & 07 & & $\mathrm{NA}$ \\
\hline $\operatorname{Los} 4214$ & $5 / 5$ & 0622 & 1415 & $22 \mathrm{E} \cup 36-209$ & 0971 & & $\mathrm{MA}_{\mathrm{A}}$ & & WA & 756,0100 & as & & $\mathrm{NA}$ \\
\hline Meplunimat-237 & $\|||$ & $006 \mathrm{B2}$ & 0 रीक्ष & 901 & 00068 & 50 & 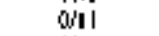 & 5 & a/1 & 272 & ól & & $N A$ \\
\hline Plalonlum-23月 & is & 00181 & 00789 & 901 & 0075 & & $\mathrm{NA}$ & & NA & LGR & 0,5 & & $\mathrm{NA}$ \\
\hline Phutomint-2 st) & $2 / 5$ & 00722 & $0 \mid(04)$ & 901 & DoBs & & NA & & NA & 14 & ars & & $N_{A}$ \\
\hline Potsing & $1] / 12$ & $394 J$ & 299 & EIJP+ted 06 & 192 & & wA & & NA & $27 y$ & 1 Lil & $32 \mid 2$ & 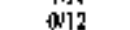 \\
\hline Prosectinum-239m & $\mathbf{I}_{\mathbf{1}}$ & 721 & 721 & 901 & 721 & & $N_{A}$ & & WA & $250,000,000$ & on & & $N_{A}$ \\
\hline Ruth decoy periest & 2424 & o & 09 & $22-\mathbf{E} U 1+216$ & 0180 & 15 & Q24 & 5 & 024 & 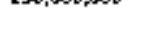 & $\mathrm{NA}$ & & NA \\
\hline 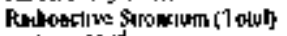 & $2 \sqrt{2}$ & 00749 & $03+3$ & S0I & 0414 & & NA & & NA & & $\mathrm{NA}$ & & NA \\
\hline kedwelat $226^{2}$ & 319 & 0797 & 1 & ETTP-RELO? & 069 & & NA & & $W_{A}$ & *26 & $9 / 3$ & 125 & org \\
\hline Sodium-22 & 01 & ND & $\mathrm{Nn}$ & & $\mathrm{KOD}$ & & NA & & $N_{A}$ & & $\mathrm{NA}$ & & NA \\
\hline 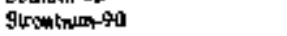 & $Q_{3}$ & No & ND & & No & & $\mathrm{NA}$ & & in & 110 & $\mathrm{OB}$ & & $\mathrm{NA}$ \\
\hline Testanetrum-99 & 2.24 & 294 & 131 & 22-EU368-301 & 802 & & NA & & $\mathrm{NA}$ & 10960 & 0,24 & & $N_{A}$ \\
\hline Lthelbum-208 & $\eta$ & 0207 & 07611 & $22 \pm \cup 56-201$ & 0416 & & $\mathrm{RA}_{\mathrm{A}}$ & & $\mathrm{NA}$ & 368,000 & 07 & & $N_{A}$ \\
\hline 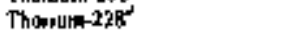 & $23: 24$ & 06793 & 183 & 22-F.056-210 & 124 & & NA & & $N A$ & 018 & $23 / 24$ & I B6 & 0 \\
\hline Thom num-230" & $2 \$ 24$ & 02281 & 215 & 22-EU\$6-210 & 119 & & $x$ & & $\mathrm{Nh}$ & 201 & 024 & 12 & $11 / 24$ \\
\hline 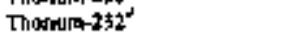 & $24 / 24$ & 021 & 187 & Z2-EU\$\$201 & ios & & $\mathrm{HA}$ & & $\mathrm{Nh}$ & 018 & $24 / 24$ & is & 0,24 \\
\hline 'Lthoriula-234 & lilo & 463 & 465 & S01 & 465 & & NA & & Nh & 32,800 & 0 & & $\mathrm{NA}$ \\
\hline Tot: ACINYIty & $1_{112}$ & 421 & 423 & S109 & 427 & & MaA & & NA & & $\mathrm{NA}$ & & $N_{A}$ \\
\hline Uramilomplad & $24 / 24$ & 0276 & 165 & sol & 300 & 3,000 & a/24 & 700 & and & 3 포 & 0.24 & & Nh \\
\hline Uhamum-23s & $13 / 24$ & 002391 & 0932 & sol & 0213 & म0 & ond & $\AA$ & a/24 & 39 & o.24 & & $\mathrm{NA}$ \\
\hline Uhanalunt 238 & 2424 & $0] 62$ & 703 & S01 & 177 & 500 & $Q / 24$ & 50 & $a / 2$ & if & 0.24 & 147 & 14244 \\
\hline \multicolumn{14}{|l|}{ 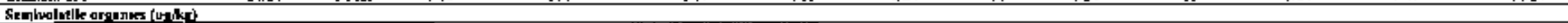 } \\
\hline 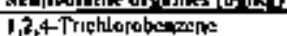 & 0,0138 & NO & MO & & $\overline{\mathrm{ND}}$ & & NA & & WA & 215,925 & 0,38 & & WA \\
\hline 1) 1)-Dxhlarobenzenc & 0 & ND & $\mathrm{ND}$ & & $\mathrm{ND}$ & & NA & & NA & 600,000 & 0,30 & & $N A$ \\
\hline I, S-Dowhlordibenzence & 0138 & WD & ND & & ND & & NA & & NA & 600,000 & DSB & & $\mathrm{NA}$ \\
\hline 1,4-[athlorebensene & 0.38 & No & No & & $\mathrm{ND}$ & & NA & & NA & 78,663 & $0 \times 5 \theta$ & & M \\
\hline i Methylnephthatenc & $2 / 4$ & $\varepsilon \mid j$ & 99 & 22-EU36E-304 & 90 & & NA & & $\mathrm{H} \Lambda$ & & $\mathrm{NA}$ & & $\mathrm{NA}_{\mathrm{A}}$ \\
\hline 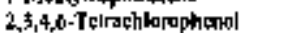 & 0,21 & NO & MD & & $\mathrm{ND}$ & & NA. & & MA & $18,468,169$ & $0 \times 21$ & & $N_{A}$ \\
\hline $2 \mathrm{~d}, 5$-Tnchlorephesoo| & 027 & $\mathrm{ND}$ & $\mathrm{Nu}$ & & $\mathrm{ND}$ & & NA. & & NA & $61,560,629$ & 0,27 & & $\mathrm{NA}$ \\
\hline 2A,6-Tnchlarophenol & 027 & ND & $\mathrm{ND}$ & & $\mathrm{ND}$ & & NA & & NA & 61,361 & 027 & & $X_{A}$ \\
\hline 2A-Dushocophuroul & 027 & nD & $\mathrm{ND}$ & & MD & & $\mathrm{NA}$ & & $N_{A}$ & $1,846,819$ & 0,27 & & $\mathrm{NA}$ \\
\hline 2,4.DEnulby|phuru] & 1.27 & II & 24: & 22.-EUड $56-310$ & 94 & & NA & & $N_{A}$ & $12,312,126$ & 027 & & WA \\
\hline 2,4-Dmidroptenot & $0 \times 27$ & et & ND & & טג & & NA & & NA & $1,23], 213$ & $0 \times 27$ & & NA \\
\hline 2,4-Dentrobioluctive & $\begin{array}{l}2027 \\
0,27\end{array}$ & WD & ND & & NP & & NA & & $\mathrm{Nh}$ & 25,348 & 0.27 & & $\mathrm{NA}$ \\
\hline 2,6 -Duntrololukne & 0,27 & W & NE] & & ND & & NA & & NA & 25,343 & $0.2 \mathrm{~J}$ & & $\mathrm{NA}$ \\
\hline 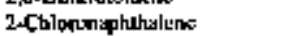 & 0.27 & MD & No & & NG & & $\mathrm{NA}$ & & NA & $23,382,732$ & $0 \times 27$ & & $\mathrm{NA}$ \\
\hline 2.cploniplicnal & D.2T & $\mathrm{m}$ & Nu & & NU & & NA. & & wa & 235.763 & Q.2T & & NA \\
\hline 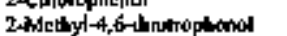 & 0,27 & $m$ & ND & & N & & $\mathrm{NA}$ & & $N A$ & $6 \mathrm{t}, 56 \mathrm{t}$ & 0,27 & & NA \\
\hline 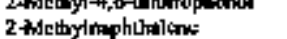 & 1327 & $2 \rightarrow 61$ & 10,000 & 22-E(136-203 & $12 \mid 7$ & & NA & & NA & I87,699| & a.2 5 & & $\mathrm{NA}$ \\
\hline 2-Autbylphenil & 0,27 & MD & $\mathrm{ND}$ & & $\mathrm{ND}$ & & NA & & NA & $30,780,315$ & $0 / 27$ & & JRA \\
\hline 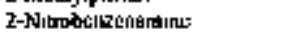 & $0 \times 27$ & No & ND & & ND & & NA & & $\mathrm{W} A$ & $1,830,332$ & 0.327 & & $\mathrm{NA}$ \\
\hline 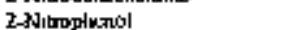 & 0,27 & no & $\mathrm{ND}$ & & ND & & NA & & NA & & $\mathrm{NA}$ & & $x_{A}$ \\
\hline 3,3:Dechlorobtenzinding & 027 & , vo & 赑 & & ND & & NA & & NA & 38,504 & 0,27 & & $N_{A}$ \\
\hline 3.MAchylphumes] & 021 & nD & NE] & & דינון & & NA & & NA & $30,780,315$ & 0,21 & & NA \\
\hline 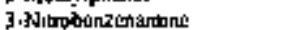 & $0: 7$ & no & $\mathrm{ND}$ & & N & & NA & & NA & $1 \mathrm{~B}, 460$ & (N27 & & $N A$ \\
\hline 4.Eromophonyl photorl olluer & 027 & No & $\mathrm{Nh}$ & & מוא & & NA & & NA & & $N_{A} A$ & & WA \\
\hline A-Cluves-3-mentrylphenal & 0,27 & No & ND & & $\mathrm{ND}$ & & NA & & $\mathrm{NA}$ & & $\mathrm{NA}$ & & $N_{A}$ \\
\hline
\end{tabular}


Tabla A.3, (condinuert)

\begin{tabular}{|c|c|c|c|c|c|c|c|c|c|c|c|c|c|}
\hline Analylt & 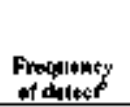 & Malinimbin & $\begin{array}{c}\text { Maximetim } \\
\text { dhilest }\end{array}$ & 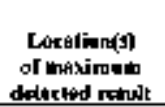 & Alerags & $\begin{array}{c}\text { Mhximut } \\
\text { RL }\end{array}$ & 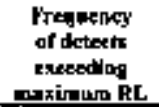 & 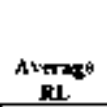 & 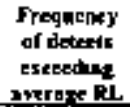 & 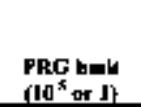 & 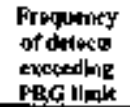 & $\begin{array}{l}\text { Bprkerouad } \\
\text { empeellirution }\end{array}$ & 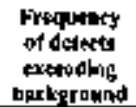 \\
\hline 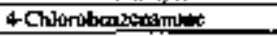 & 0,27 & $\mathrm{Na}$ & ND & & ND & & $\frac{N \not 2}{N}$ & & N & $2,462.425$ & 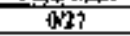 & & EA \\
\hline 4Choropheny] pherryl calier & 0,27 & No & ND & & ND & & NA & & NA & & $\mathrm{NA}$ & & $\overline{N A}$ \\
\hline 4-Mclloylphenos & 0,6 & No & ND & & No & & NA & & $\mathrm{N} \Lambda$ & 3,] & D.6 & & NA \\
\hline 4-Nilouteizenamme & 037 & ND & ND & & MD & & NA & & NA & $184,64 \mathrm{~B}$ & $0 \times 27$ & & NA \\
\hline 4Milrophionol & (b2) & No & NLS & & No & & $\mathrm{NA}$ & & NA & & $N_{A}$ & & NA \\
\hline Acunaphiture & $2 / 27$ & 520 & 10,000 & $72-E 00668-310$ & 3,260 & & NA & & $\mathrm{NA}$ & $29,279,327$ & $0<27$ & & NA \\
\hline Astinapmbyliske: & 327 & (4) & $150 \mathrm{~J}$ & $22-E 036-203$ & 117 & & $\mathrm{~N} n$ & & NA & $29,219,327$ & 027 & & NA \\
\hline Amlım: & $a / 21$ & ND & $\mathrm{KD}$ & & No & & $\mathrm{NA}$ & & $\mathrm{NA}$ & $3,024,031$ & $0+21$ & & $N_{A}$ \\
\hline Aurhuravomo & $6 / 27$ & ม]1 & 28,000 & $Z 2-E 40366-310$ & $4,9] 4$ & & $\mathrm{NA}$ & & $\mathrm{NA}$ & $\mathrm{JNO}, 000,000$ & 0,27 & & NA \\
\hline 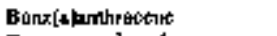 & $92 ?$ & $360 \mathrm{~s}$ & 91,000 & 72 -EU966-310 & 4,452 & & $\mathrm{NA}$ & & NA & 21,096 & 1027 & & NA \\
\hline Binzentranthifinot & $0: 21$ & ND & MD & & ND & & $\mathrm{N} / \mathrm{M}$ & & $\mathrm{N} / \mathrm{A}$ & נ & 021 & & $\mathrm{NA}$ \\
\hline 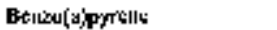 & 8,37 & 3SEF & 25,000 & Z2-E056B-310 & 4,259 & & NA & & NA & 2,110 & $2 / 27$ & & $N_{A}$ \\
\hline 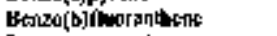 & 3027 & 1241 & 34,000 & $22-E 036 \mathrm{~B}-310$ & $5,0 \mathrm{ma}$ & & NA & & NA & 21,0006 & $1 / 27$ & & NA \\
\hline Bonzolghinperylew & 8127 & $|600|$ & 5,200 & 72-E0156B-310 & 3.492 & & $\mathrm{NA}$ & & $\mathrm{NA}$ & $29,126,20]$ & 027 & & NA \\
\hline 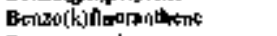 & 427 & 1921 & 15,000 & Z2.EN360-310 & 3,469 & & $\mathrm{~N} n$ & & NA & 210,062 & 0.27 & & NA \\
\hline Bancoese wivd & $0-2]$ & ND & MD & & ND & & NA & & $\mathrm{NA}$ & $100,000,0 \times 0$ & 0,21 & & NA \\
\hline 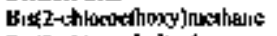 & arzi & NU & No & & No & & NA & & NA & & EA & & NA \\
\hline 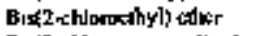 & 027 & ND & No & & NO & & NA & & $\mathrm{Nh}$ & 5,755 & 027 & & NA \\
\hline 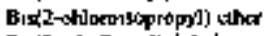 & $0 / 27$ & ND & SD & & MD & & NA & & NA & 73,518 & 0.27 & & NA \\
\hline 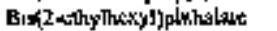 & 5027 & 215] & $3,000]$ & Z2-EU36E-305 & 969 & & NA & & No & $1,231,213$ & W 27 & & NA \\
\hline Bulyl burryl phthalate & on? & No & NL & & 50 & & NA & & NA & $100,000,000$ & 1027 & & $\mathbf{N A}$ \\
\hline Corbarzols & 327 & 120,5 & B, 500 & Z2-EU36\&-310 & 3020 & & $\mathrm{NA}$ & & NA & 861,849 & on? & & $N A$ \\
\hline Churanac & $9 / 26$ & 191) & $2.2 \mathrm{RO}$ & gol & $9 * 3$ & & $\mathrm{Nh}$ & & NA & $2,109,623$ & 0,26 & & WA \\
\hline 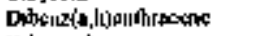 & 3121 & 3903 & 1,700 & Z2-EU\}60. 310 & 957 & & $\mathrm{NA}$ & & NA & 2,110 & 0,27 & & Wh \\
\hline Dotrollzoflean & 227 & 2 갸: & 7,200 & $27 \cdot \mathrm{E}(3568-3) 0$ & 3,735 & & $\mathrm{NA}$ & & $\mathrm{NA}$ & $1,5,63,342$ & 0,27 & & AA \\
\hline Dwethy] philtastme: & 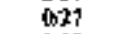 & No & $\mathrm{ND}$ & & $m$ & & $\mathrm{NA}$ & & NA & $100,000,000$ & $0+27$ & & NA \\
\hline Demuthyl phahalese & 027 & No & ND & & ND & & $\mathrm{Nh}$ & & NA & $100,000,000$ & $0 \times 27$ & & ANA \\
\hline Do-n-bưlyl phthalak & 6127 & No & Wo & & WD & & $\mathrm{NA}$ & & $\mathrm{NA}$ & $61,560,629$ & $0+27$ & & EAA \\
\hline 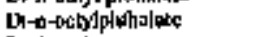 & 027 & ND & $\mathrm{kV}$ & & WD & & $\mathrm{NA}$ & & NA & $24,624,252$ & 027 & & NA \\
\hline Dohemylatinne & 0,6 & Nn & wD & & ND & & $\mathrm{NA}$ & & $\mathrm{NA}$ & $15,000,000$ & 0.6 & & NA \\
\hline Diphenyldhaseno & 021 & ND & $\mathrm{ND}$ & & ND & & $\mathrm{NA}$ & & $\mathrm{NA}$ & 156,700 & 0,21 & & NA \\
\hline Fuorsulthers: & 1247 & $79]$ & 91,600 & 22. EUy60.310 & 9,073 & & $\mathrm{NA}$ & & $\mathrm{NA}$ & $22,000,353$ & $0 / 27$ & & NA \\
\hline Flustant & 327 & $28 \% 4$ & $\sqrt{11,000}$ & $22 \cdot E U 368-310$ & 4,010 & & $\mathrm{Nm}$ & & $\mathrm{NA}$ & $26,281,433$ & 027 & & NA \\
\hline 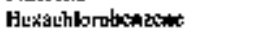 & $\operatorname{arn} 7$ & ND & Wa & & NDD & & $\mathrm{NA}_{\mathrm{A}}$ & & $\mathrm{NA}$ & $10, \pi 33$ & $0 \times 27$ & & NA \\
\hline Hekachborabvolad zate & a/3 & $\mathrm{N}[\mathrm{J}$ & WD & & ND & & $\mathrm{Nh}$ & & NA & 180,882 & 038 & & NA \\
\hline 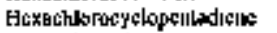 & aili 7 & N[] & ND & & HD & & $\mathrm{NA}$ & & $\mathrm{NA}$ & $3,658,717$ & 027 & & NA \\
\hline Hoxsohboructhenc & 028 & NO & No & & ND & & $\mathrm{NA}$ & & $\mathrm{NA}$ & 615,606 & 027 & & NA \\
\hline Ind:ino $\{1,2,3-60\}$ by & $9 / 27$ & 1600 & 10,000 & 22 EEI1,36R-310 & J,RIS & & $\mathrm{N} \hbar$ & & $\mathrm{NA}$ & 21,096 & 627 & & NA \\
\hline Bothoroun: & 0,27 & No & No & & ND & & $N / \AA$ & & $\mathrm{MA}$ & $5,119,796$ & 0,27 & & NA \\
\hline Naphahellenet & 20/3月 & 76 & $7,400]$ & Z7-EบU36-208 & $i, 350$ & & NA & & NA & $\mid 87,(\theta)]$ & 0.36 & & NA \\
\hline Nurobetiaene & Q 123 & ND & $N Q$ & & ND & & NA & & NA & $102,93 s$ & $0 \times 27$ & & NA \\
\hline N-NWroesdimethylamins & a.2] & ND & ND & & No & & $\mathrm{NA}$ & & NA & 338 & 021 & & NA \\
\hline 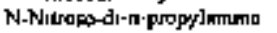 & 0.27 & ND & ND & & No & & $\mathrm{NA}$ & & NA & 2,462 & 027 & & NA \\
\hline 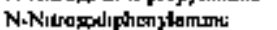 & ard & ND & ND & & $\mathrm{N}[\mathrm{F}$ & & $\mathrm{N}_{\mathrm{A}}$ & & $\mathrm{rdh}$ & $3,5] 7,350$ & $a / 21$ & & $\mathrm{NA}$ \\
\hline 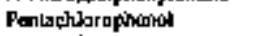 & $1 / 27$ & 2801 & 2800 & $\mathrm{~s} 0 \mathrm{H}$ & 2840 & & NA & & $\mathrm{NA}$ & 39,982 & 027 & & NA \\
\hline Pbenanderuns & 3127 & 7i) & $B 5,000$ & 22-EU36E-910 & 7.453 & & $\mathrm{NA}$ & & $\mathrm{NA}$ & $29,126,20]$ & $0 \times 27$ & & NA \\
\hline Phanol & 027 & No & $\mathrm{N}[\mathrm{B}$ & & ND & & NA & & $\mathrm{NA}$ & $i 00,0 \infty, 000$ & ar 27 & & NA \\
\hline Pуюші & 73 & (89) & 7,000 & 22.EU368.310 & 7,413 & & $N h$ & & NA & $29,126,20]$ & 627 & & $N_{A}$ \\
\hline Pyndille & 421 & $N[$ & $\mathrm{MO}$ & & ND & & $\mathrm{NA}$ & & NA & 6]5, 606 & $0>1$ & & NA \\
\hline \multicolumn{14}{|l|}{ 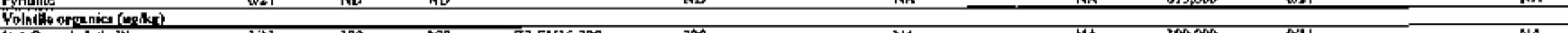 } \\
\hline 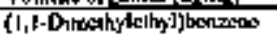 & נji] & 390 & 590 & $77-5 U 36-2008$ & 300 & & NA & & NA & 390,000 & WII & & NA \\
\hline
\end{tabular}


Tablo A.3. (comtinued)

\begin{tabular}{|c|c|c|c|c|c|c|c|c|c|c|c|c|c|}
\hline Anolyts & $\begin{array}{l}\text { Freaguney } \\
\text { w delect" }\end{array}$ & Minionimon & 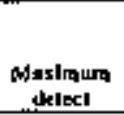 & 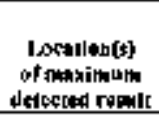 & $\begin{array}{c}\text { Averise } \\
\text { defected reawly }\end{array}$ & $\underset{\text { RL }}{\text { Masumanm }}$ & $\begin{array}{c}\text { Drequency } \\
\text { of doteets } \\
\text { escecoding } \\
\text { mertmum RL }\end{array}$ & $\begin{array}{l}\text { Averate } \\
\text { BI }\end{array}$ & 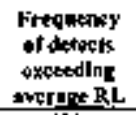 & $\begin{array}{l}\text { PRC Illmit } \\
\text { (It) or I) }\end{array}$ & 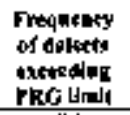 & 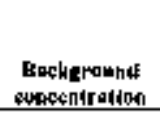 & 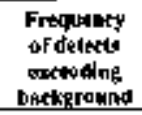 \\
\hline 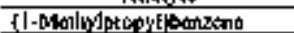 & 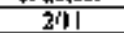 & $\frac{1}{21}$ & 1,300 & C2-EU136-20g & $\phi \infty$ & & $\mathrm{NA}$ & & NA & 220,000 & बiा & & NA \\
\hline I,1,1,2,Tetracl|dorecthome & all & ND & ND & & ND & & NA & & NA & 72,755 & 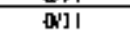 & & MA \\
\hline 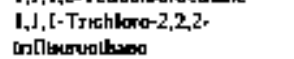 & $\alpha T$ & ND & ND & & $\mathrm{MD}$ & & $N_{A}$ & & $\mathrm{NA}$ & & $M_{A}$ & & NA \\
\hline 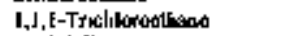 & 0 & sav & Ny & & עי & & NAG & & NA & $1,200,000$ & $\left.0^{\prime}\right] 8$ & & NA \\
\hline 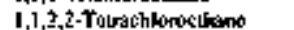 & W18 & No & ND & & $\mathrm{AD}$ & & NA & & NA & 9,294 & 1/8 & & $M_{A}$ \\
\hline 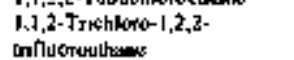 & (1) & ND & wD & & No & & $N A$ & & NA & $5,600,0000$ & a & & $N \wedge$ \\
\hline 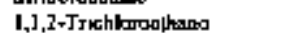 & ajs & ND & Mע & & WD & & NA & & NA & 16,050 & Qu'B & & NA \\
\hline I,] Deklorathane & o's & ND & ND & & ND & & NA & & $\mathrm{NA}$ & $1,734,654$ & o'les & & $M_{A}$ \\
\hline I, I-Dhchlorosthaung & $\left.0^{\prime}\right] \mathrm{B}$ & ND & MD & & ND & & $N_{A}$ & & NA & 419,325 & o'd8 & & $M_{A}$ \\
\hline I, $]$-Dichturupmopene & OIII & ND & ND & & ND & & NA & & $\mathrm{No}$ & & NA & & $w_{A}$ \\
\hline 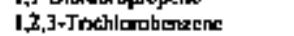 & Qil & ND & ND & & No & & NA & & No & & NA & & $w_{A}$ \\
\hline i, 2,3. Trichkeropropense & ונואט & ND & NE & & NO & & NA & & $N A$ & 760 & וויטו & & NA \\
\hline I,2,4-Trimshybenzodos & 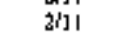 & 451 & $45,0,00$ & Z2-EU16-2018 & 23,502 & & $\mathrm{NA}$ & & NA & $10,2 \pi 2$ & | ll & & $N A$ \\
\hline 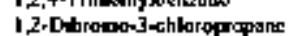 & Q & MD & ND & 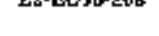 & $\mathrm{MD}$ & & $N_{A}$ & & NA & נו, & all & & $M_{A}$ \\
\hline 1,2-Dhbroigocthoos & a'd। & ND & ND & & $\mathrm{ND}$ & & NA & & NA & 630 & oxil & & $N A$ \\
\hline 1,2.Dhchoordethage & o'je & ND & ND & & ND & & NA & & $N_{A}$ & 6,035 & $0^{\prime} 18$ & & NA \\
\hline 1,2-Dncturomodthene & 097 & ND & MD & & ND & & NA & & NA & $1,00,000$ & on & & $\mathrm{NA}$ \\
\hline 1.7.Deklochoripape & [i]g & $25 \mathrm{E}$ & $250 \mathrm{~J}$ & Z2-EU36-208 & 250 & & N.G & & NA & $7,4 \geqslant 2$ & 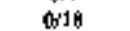 & & wh \\
\hline 1.2. Dhenclby benterenc & iaj2 & 23,000 & 23,000 & Z2-EU36-208 & 23,000 & & NÁ & & $N_{A}$ & 420,000 & 0 & & $M A$ \\
\hline 1,5,-Trincthylounzene & |i]| & 20,000 & 20,000 & 27.EU36-20\% & 80,000 & & NÁ & & Nad & 69,712 & | & & $m_{h}$ \\
\hline I, -Dichloropopases & 保I & ND & wo & & ND & & NA & & NA & 360,501 & WII & & $M A$ \\
\hline [-ClbHHy-d-moulhy]throsmo & bij। & ND & ND & & HD & & $\mathrm{NA}_{A}$ & & $\mathrm{NA}$ & & Wh & & $N_{A}$ \\
\hline 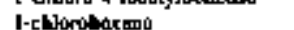 & (ri1 & NU & ND & & No & & NA & & NA & & NA & & WA \\
\hline 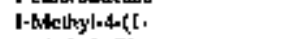 & zill & 14 & 3.800 & 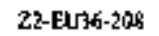 & 1,907 & & $\mathrm{NA}$ & & $\mathrm{NA}$ & & NA & & WA \\
\hline 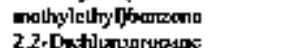 & & & & & & & & & & & & & \\
\hline 2,2-Dutilouprupans & ond & $g^{N D}$ & $\underset{\$, y]}{N[]}$ & $22-\cos 3 x-203$ & 5 & & $\begin{array}{l}N A \\
N A\end{array}$ & & $\begin{array}{l}\text { NA } \\
\text { NA }\end{array}$ & J13,264,388 & $\begin{array}{l}\text { NA } \\
0,1 B B\end{array}$ & & $\begin{array}{l}\mathrm{NA} \\
\mathrm{NA}\end{array}$ \\
\hline $2, H z x+\log 5$ & 政 & NO & Nn & & $\$$, & & $\mathrm{NA}$ & & NA & & $N A$ & & $\mathrm{NA}$ \\
\hline 2-Molhoxy 2 -melhypropano & (1II & 괴잉 & ND & & $\mathrm{NSD}$ & & NA & & NA & 700,000 & ו ווא & & $\mathrm{MA}_{\alpha}$ \\
\hline 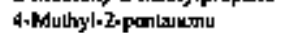 & o'je & ND & $\mathrm{ND}$ & & no & & NA & & NA & $47,0 \mathrm{BI}, 434$ & O'IB & & $\mathrm{N} / \mathrm{A}$ \\
\hline Acóteñó & $y / 18$ & 171 & 4901 & $Z_{2}$-EU96B-903 & 3,326 & & $\mathrm{NA}$ & & NA & $54,520,966$ & o's & & NA \\
\hline Berrenc & lion & 640 & $6+10$ & Z2-F1Y3-20R & 640 & & NA & & $N_{A}$ & 14,094 & o's & & $\mathrm{NA}_{\mathrm{A}}$ \\
\hline 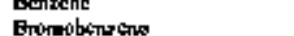 & I & N] & NO & 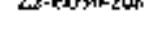 & ND & & $N_{A}$ & & NA & 92,152 & Wil & & $m_{n}$ \\
\hline 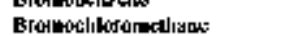 & (1) & $\mathrm{ND}$ & Dי & & MD & & NA & & Nh & $8 \sum_{1} 132$ & Ns & & $M_{A}$ \\
\hline 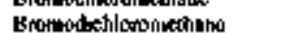 & arlB & ND & N & & ND & & NA & & NA & 18,306 & Gilk & & MA \\
\hline Brotwo font & (ving & ND & ND & & ND & & NÁ & & NA & $2.181,998$ & Gik & & $\mathrm{NA}$ \\
\hline Grotrowethans. & W] & ND & $\mathrm{ND}$ & & $\mathrm{MD}$ & & NA & & NA & 13,078 & (N] & & $M_{A}$ \\
\hline Bwalkonzectu & 2110 & 32 & 2,900 & 22.QU36.208 & $1,+6[$ & & NA & & $\mathrm{NA}_{A}$ & 240,000 & וניט, & & $\mathbf{N A}$ \\
\hline 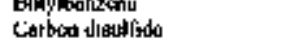 & Bו & No & ND & & שיא & & $N_{A}$ & & $\mathrm{NA}$ & $T^{2} 0,000$ & ONI & & NA \\
\hline Corbow 10urachtoride & (N) 18 & ND & $\mathrm{so}$ & & ND & & NA & & $\mathrm{NA}$ & 5,493 & WIE & & NA \\
\hline 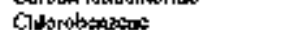 & W & ND & WD & & MD & & NA & & NA & 530,466 & WIE & & NA \\
\hline Clukroutunu & (1) & NO & kO & & KD & & NA & & $\mathrm{NA}$ & on, sis & Wu & & $\mathrm{NA}$ \\
\hline 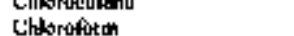 & 年 & $\mathrm{NO}$ & ND & & My & & $N_{A}$ & & NA & 4,698 & Wug & & $M A$ \\
\hline Chbrotmolthanes & (n) & Nn & ND & & MD & & $\mathrm{NA}_{A}$ & & $\mathrm{NA}$ & 155,746 & WIIB & & $N_{A}$ \\
\hline 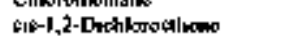 & o' & ND & ND & & No & & NA & & NA & 146,301 & 0 & & $\mathrm{NA}$ \\
\hline - & $o^{\prime} 1 k$ & NO & $\mathrm{kD}$ & & ND & & $\mathrm{NA}$ & & $\mathrm{NA}$ & $17,6 \mathrm{~d} 5$ & owe & & $N A$ \\
\hline (y) & 201 & 15 & 3000 & 0.6136 .205 & 1500 & & Na & & NA & 520000 & o' I I & & pes \\
\hline Dibrowechlorounthere & OII & ND & ND & & ND & & $\mathrm{NA}$ & & NA & $25,5,13$ & $0 \times 18$ & & $\mathrm{NA}_{\mathrm{A}}$ \\
\hline Dobromancenthape & ונוניו & ND & ND & & TW & & NG & & $N_{A}$ & $239550^{\circ}$ & | & & $\mathrm{HA}_{\mathrm{A}}$ \\
\hline
\end{tabular}


Table A 3 (canlimuad)

\begin{tabular}{|c|c|c|c|c|c|c|c|c|c|c|c|c|c|}
\hline Anulyis & $\begin{array}{l}\text { Frequency } \\
\text { of defectlol }\end{array}$ & 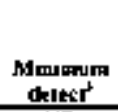 & $\begin{array}{c}\text { Moumer } \\
\text { Adirst }\end{array}$ & 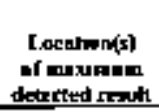 & 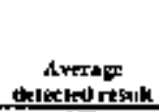 & $\begin{array}{c}\text { Maxamat } \\
\text { RL } \\
\end{array}$ & $\begin{array}{l}\text { Frequency } \\
\text { of dekerts } \\
\text { expectur } \\
\text { makulurth RL }\end{array}$ & $\begin{array}{c}\text { Awerage } \\
\text { BLL }\end{array}$ & 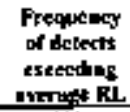 & $\begin{array}{l}\text { PRG hant } \\
\left(10^{5} \text { or } 1\right)\end{array}$ & $\begin{array}{l}\text { Frequency } \\
\text { of detert } \\
\text { aceedlog } \\
\text { PRG Lert }\end{array}$ & 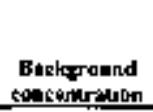 & 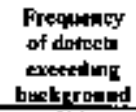 \\
\hline Dechlorodt fluosomclhant & 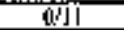 & ND & WD & & ND & & $N A$ & & $N A$ & 308058 & |vi| & & NA \\
\hline Bdhylbetaghe & 249 & II & 20,000 & $22-A 036-2018$ & 30,006 & & NA & & NA & 39.000 & (x) & & Wh \\
\hline beronathentic & olla & nto & No & & ND & & $\mathrm{NA}$ & & NA & & $\mathrm{I}_{A}$ & & WA \\
\hline$M+P X y k=n \hat{n}$ & 2112 & $2 \mathrm{~J}$ & 65,000 & $22-E 0160-20 \theta$ & 32,501 & & Na & & NA & 420.000 & $0 / 32$ & & NA \\
\hline Metiylone thlurule & $1 / 196$ & i if & i IJ & sol & l1 & & NA & & NA & 205369 & WaB & & NA \\
\hline o-ChJorotutulons & Q & ND & $\mathrm{ND}$ & & ND & & $\mathrm{NA}$ & & $\mathbf{S}+\mathbf{A}$ & $960,0 \mid 0$ & וורט & & WA \\
\hline 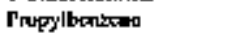 & LI & 25 & 6,500 & 22 EU36 200 & 3263 & & $\mathrm{NA}_{A}$ & & SA & 240,000 & oll & & NA \\
\hline \$̦tyado & (B) & se & ND & & NO & & NA & & $\mathrm{kA}$ & $1,700,000$ & WIB & & NA \\
\hline Tofrochlnmeshens & Зи & $07 \mathrm{~T}$ & (n) $\mathrm{Bg}$ & s03 & 083 & & WA & & vis & 13,008 & NIF & & $\mathrm{NA}$ \\
\hline Jolexen & 419 & 0321 & $8,400]$ & 22.EU36-208 & 1.300 & & NA & & NA & 520,000 & b/19 & & $\mathrm{ket}$ \\
\hline Julal Xykne & art & SD & $\mathrm{ND}$ & & $\mathrm{ND}$ & & NA & & NA & 420,000 & OS & & $\mathrm{kA}$ \\
\hline bart 1,2-Uschurrodhano & vi2 & $\mathrm{MD}$ & ND & & ND & & NA & & NA & 234.623 & 20 - l2 & & NA \\
\hline 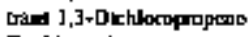 & Nis & ND & $\mathrm{ND}$ & & ND & & NA & & $\mathrm{NA}$ & [7.641 & a & & $S_{A}$ \\
\hline Tndhluroolhens & a]k & so & ND & & ND & & NA & & $S_{A}$ & 1,341 & $0 \times 18$ & & $N_{A}$ \\
\hline Tmthl|usotheosuresthen: & Q & mo & ND & & ND & & $\mathrm{NA}_{A}$ & & NA & $1,276,074$ & anil & & $M_{A}$ \\
\hline Yony] acouns & Qjul & ND & $\mathrm{ND}$ & & $\mathrm{ND}$ & & NA & & NA & $1,396,422$ & (N) I & & NA \\
\hline Vmblutorlde & Q'] & No & $\mathrm{ND}$ & & ND & & NÁ & & $N A$ & 7.461 & NAB & & WA \\
\hline
\end{tabular}

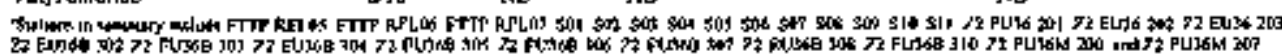

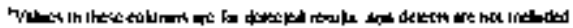

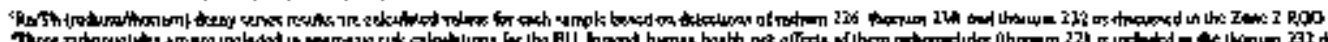

等

In subie wis peon

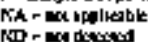

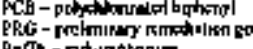

GSTR-mdunhtonLm 